

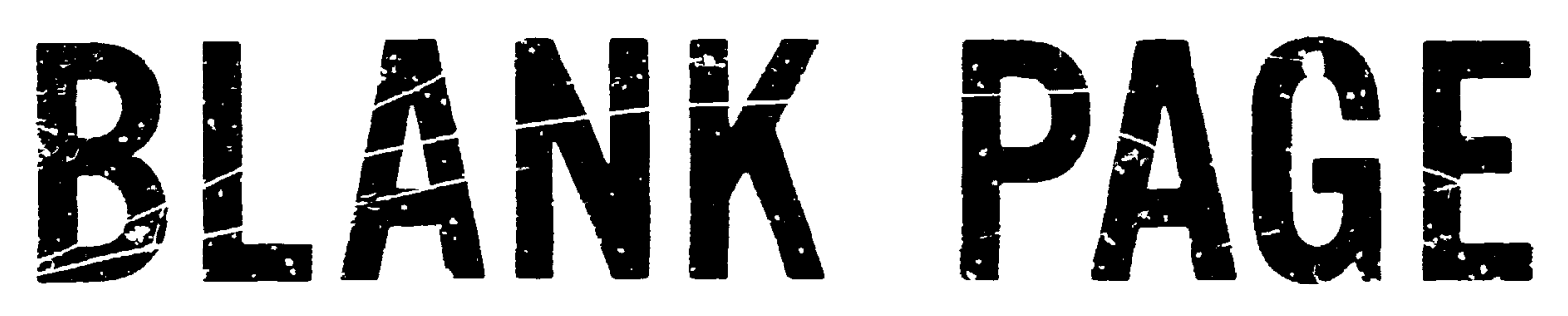




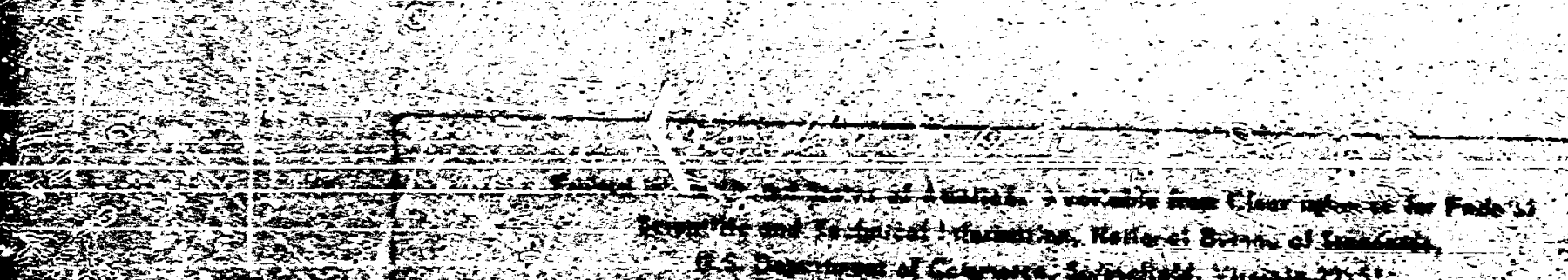

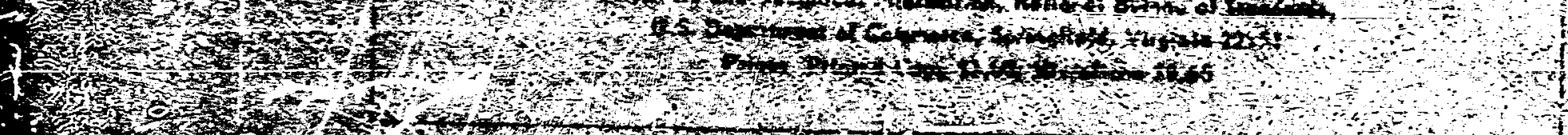

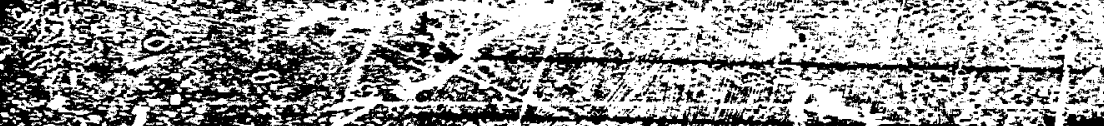

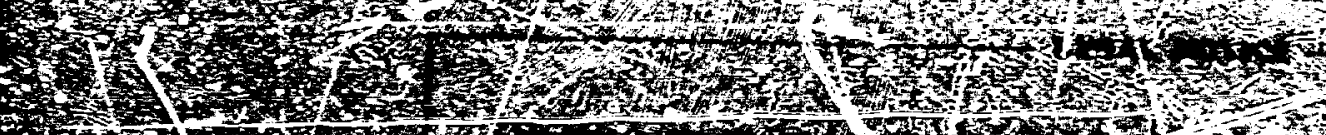

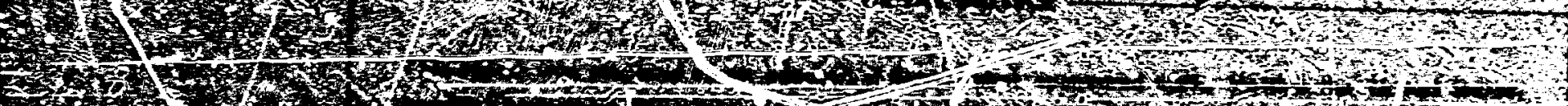

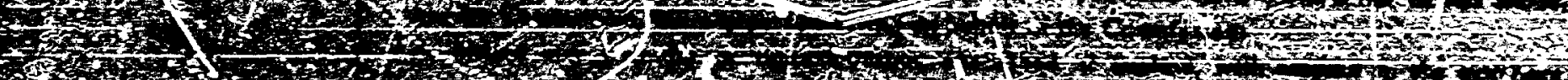
(5)

thes

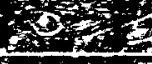

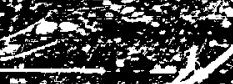

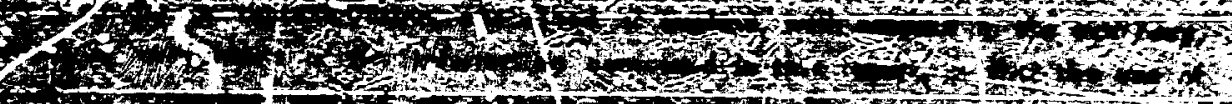

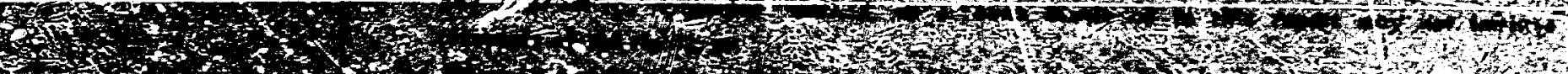

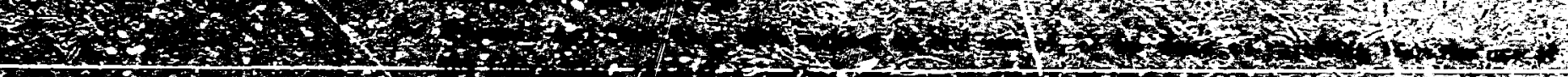

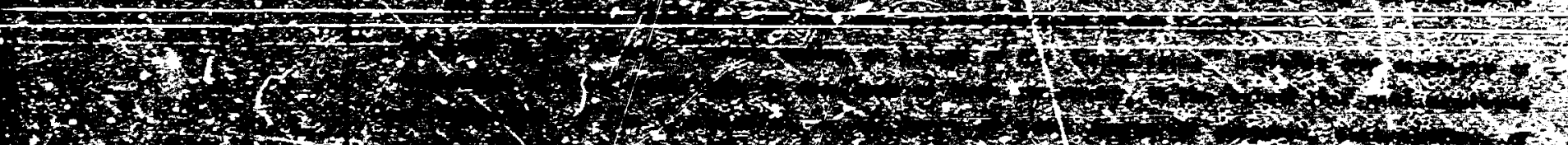

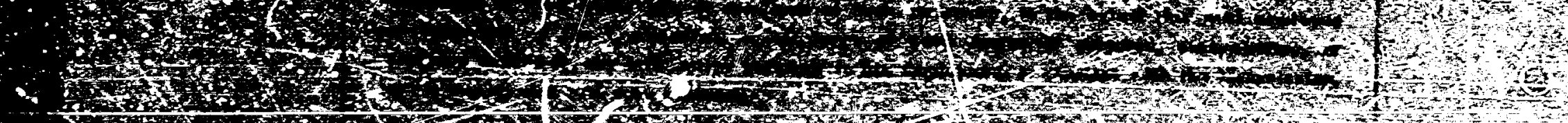

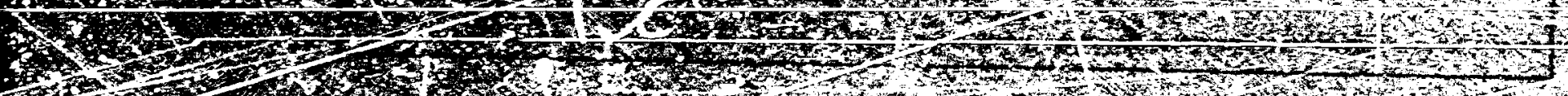

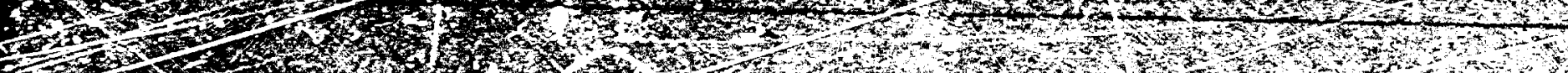

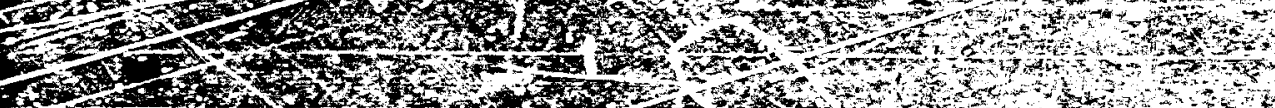

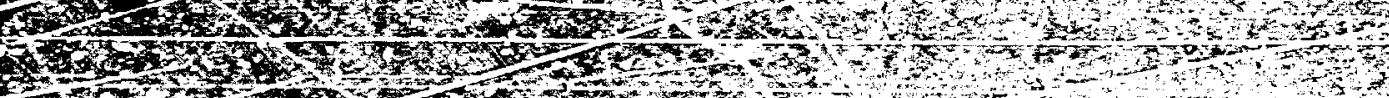

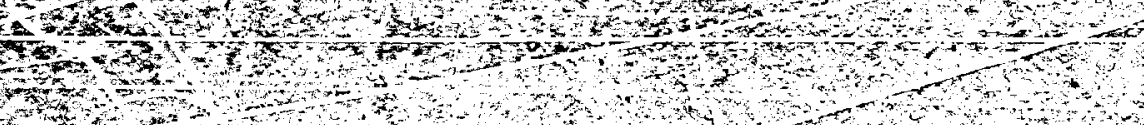

6.

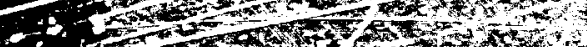

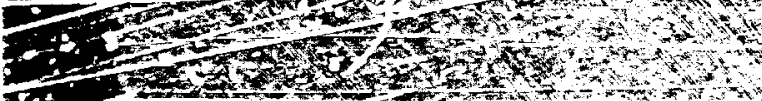

(1)

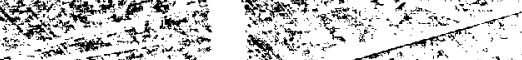

$\operatorname{lom}_{0}$

$x^{2}$

- m

com

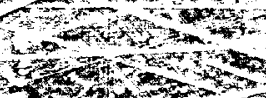

1) 420

ar 1

$1, x<2$

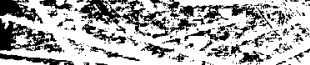




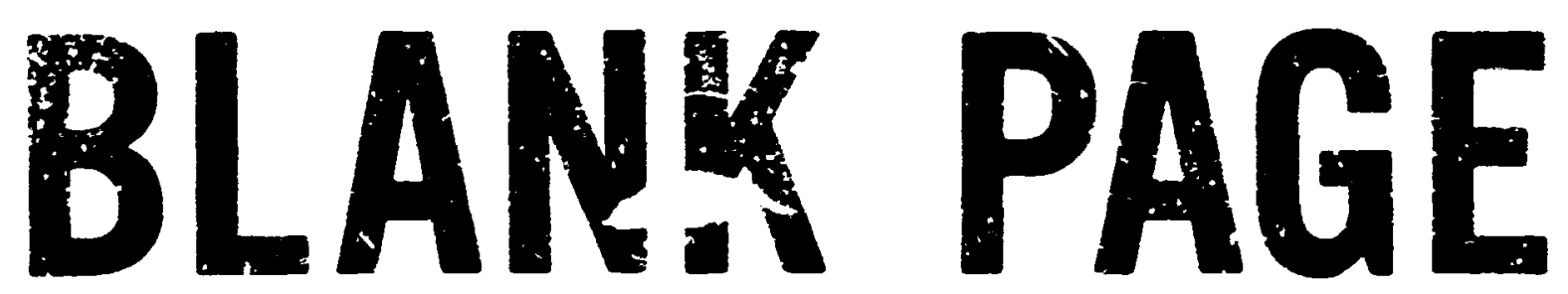


ORNL-1528

UC-80 - Reactor Technolngy

Contract No. W-7105-rag-26

REACTOR DIVISION

TWO-FLUID MOLTEN-SALT BREEDER REACTOR DESIGN STUDY (STATUS AS OF IAN JARY ¿, 19EQI

R. C. Robertsor.

O. L. Smith

R. B. Briggs

E. S. Bettis

LEGAL NOTIEE

This iefort was prepared as an account of wot sponsored by the Urited States Governinent. Neither the U:ited States nor the Linited States Atomin Fnerzy Commincion, nor any of the it employees, nor any of their sontractors, subcontractors, of their singloyees, makes any warranty, express or implied, or assumes any lecal liability or responsibility for the accuracy, completeness or usefulness of any information, apparatus, product or process disclosed, or represents ths' its use would not infringe privately owned rights.

AUGUST 1970

\author{
OAK RIDGE NATIONAL LABORATORY \\ Oak Rider, Tennesioe \\ operoted by \\ UNION CARBIDE CORPORATION \\ for the \\ U.S. ATOMIC ENERGY COMMISSION
}




\section{CONTENTS}

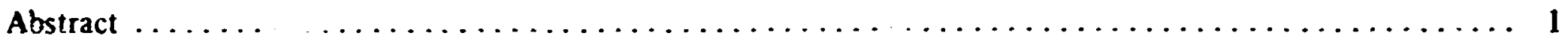

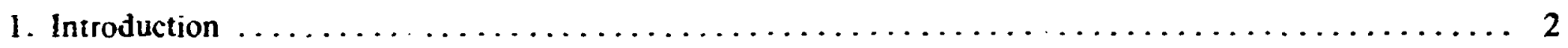

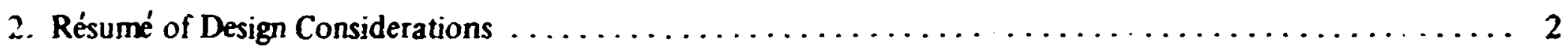

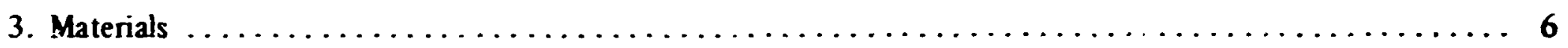

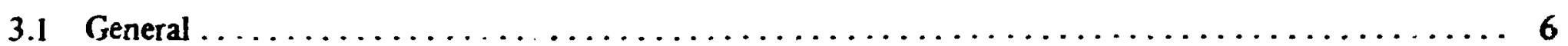

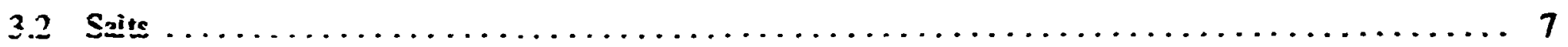

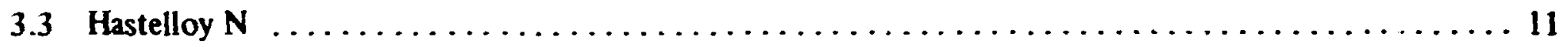

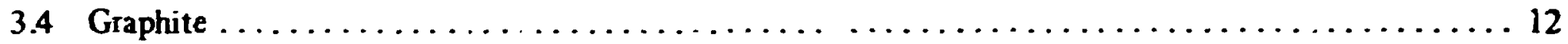

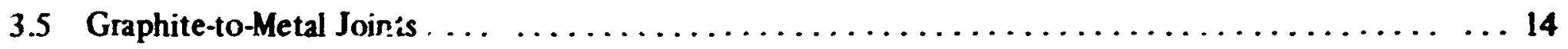

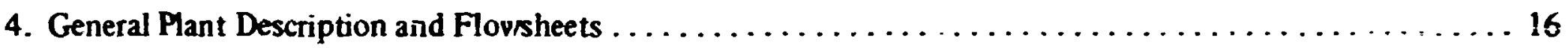

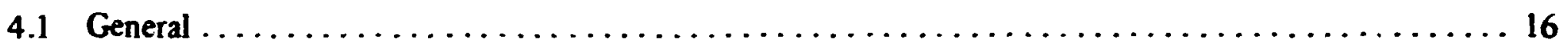

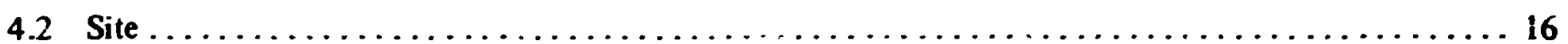

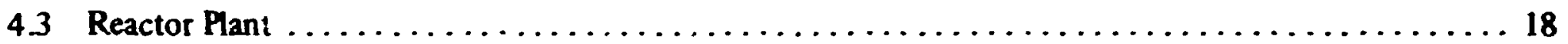

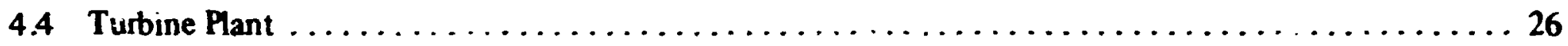

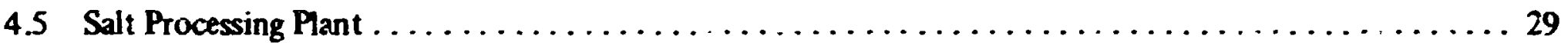

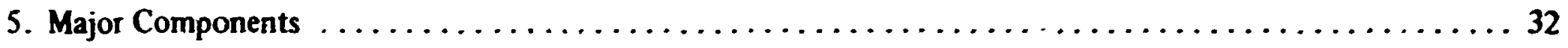

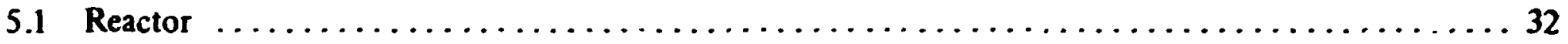

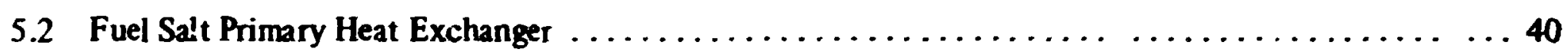

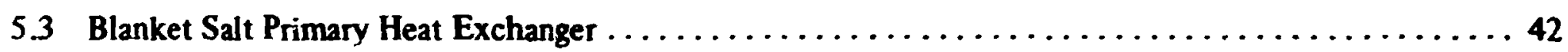

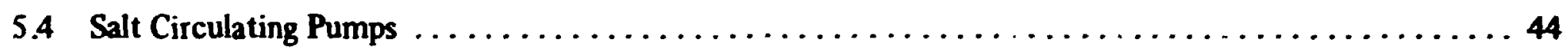

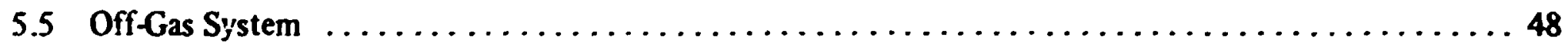

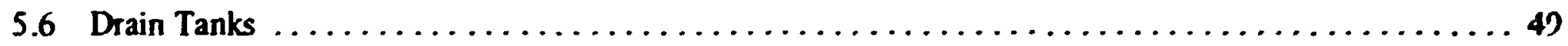

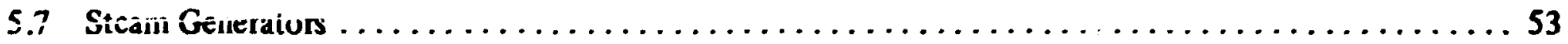

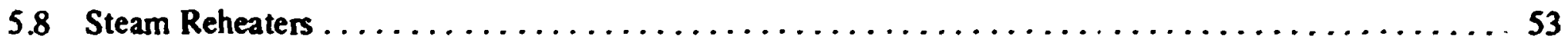

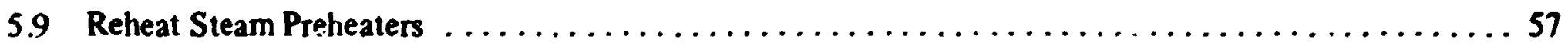

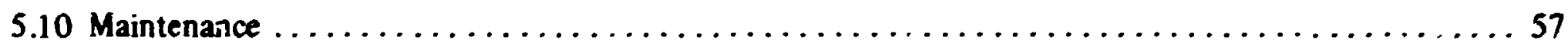

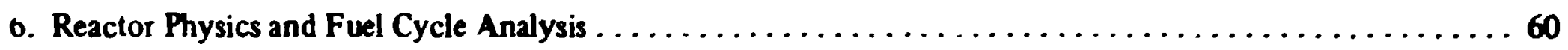

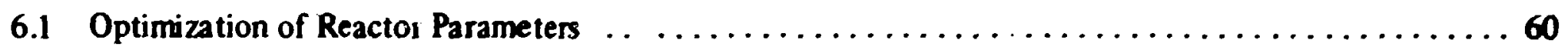

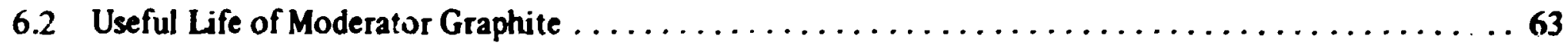

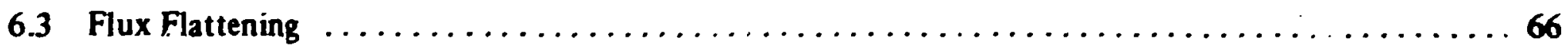

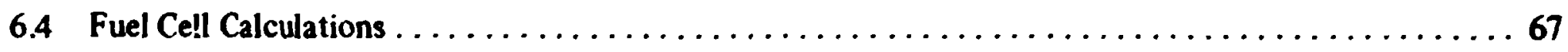

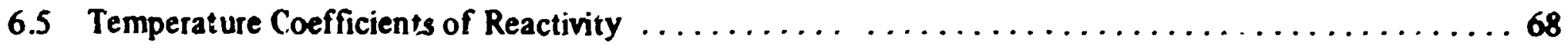

6.6 Dynamics Analysis . . . . . . . . . . . . . . . . . . . . . . . . . . . . . . . 


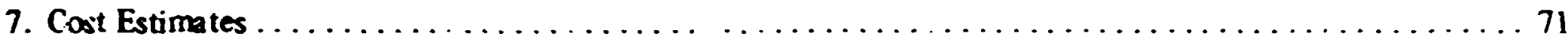

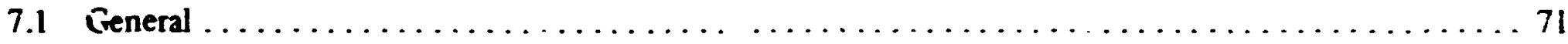

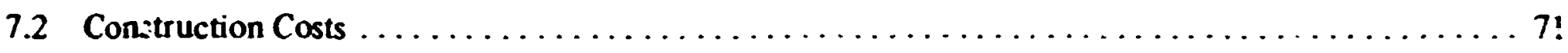

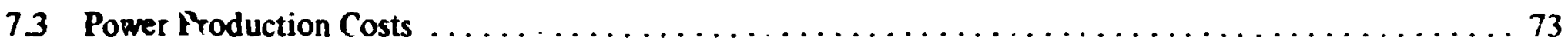

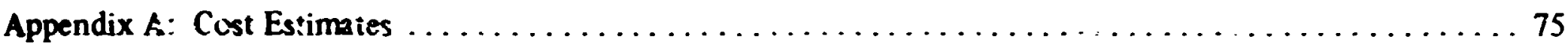




\title{
TWO-FLUID MOLTEN-SALT BREEDER REACTOR DESIGN STUDY (STATUS AS OF IANUARY 1, 1968)
}

\author{
R. C. Robertson \\ O. L. Smi h \\ R. B. Brigss \\ E.S. Bettis
}

\begin{abstract}
A conceptual design study of a 1000-Mw(e) thermal breeder power stution based on a two-fluid MSBR was commenced in 1966 as part of a program to determine whetret 3 molten-salt reactor using the thorium- ${ }^{23} \mathrm{y}$ fuel cycle could produce electric power at sufficiently low cost to be of interest and at tine same time show good utilization of U.S. nuchar fuel rescarces. This report covers the progress mode in the study up to Augut 196?, at wich time the tmu-finid MSBR work was set acide in ordes to study a single-fluid MSBR conceft. The atter becane of interest at that time due to the discovery that protactinium and other fission products could be separated from a uranium-and-thorium-tearing fuel salt by reductive extraction into biquid kismuth.

The two-fluid MSBR is graphite-moderated and reflected, with a ${ }^{7}$ LiF-BeF $2-U F_{4}$ fuel salt circulated through the core and a ${ }^{7} \mathrm{LiF}-\mathrm{ThF}_{4}-\mathrm{BeF}_{2}$ blanket salt circulated through separate flow channets distributed throughout the care, as well as in a sumounding undermodersted region. The fiscions raise the temperature of the fued salt to about 1300 T and that of the blanket silt to about $1250^{\circ} \mathrm{F}$. Heat is removed from the salts in shell-and-tube beat exchangers to raise the temperature of : circuititing $\mathrm{NaBF}_{4}-\mathrm{NaF}_{2}$ coolant salt to about $1 \mathrm{i} 50^{\circ} \mathrm{F}$. The coolant salt tratsports the heat to steam generators and reheaters to provide 3500 -psin $1000^{\circ} \mathrm{F} / 1000^{\circ} \mathrm{F}$ steam for a saventional turbinc generator.
\end{abstract}

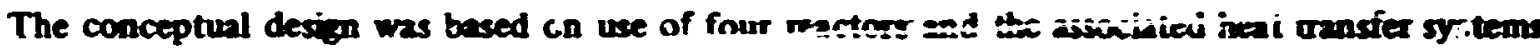
in a so-called modutar arrangement to supply steam to a single turbino-generator. This made it practical to consider rephacement of an extire reaciss vessed assembly after the core graphite received is allowable exposure to neutrons. The total fuence at which it was thought that additional graphite dimensional changes would become excessive was takes s $3 \times \mathrm{i0}^{22}$ neutrons/ $\mathrm{cm}^{2}$ (E $\left.>50 \mathrm{kev}\right)$, or about eight years of full-power operation.

All partions of the systems in contzct with the fluoride or flusroborate salts woukd be fabricated of Hastelloy $\mathbf{N}$ that ha- 2 small amount of titanium added to isapto: the resiotunce to radiation damage. The graphite would be a specially conted grade having low gas permenbility to xenon and better resistance to rediation damage than conventional mateial. The two-fluid concept involves joining gnphite core elements to Hastelloy $N$ tubing using a brasing process developed at ORNL.

The reactors and associnted systems would be howsed in concrete cells to provide biolosical shielding and double containment of all radionctive anterials.

Phnt flowsheets and layouts were developed sufficiently during the study to give an indication of feasibility and to give a basis for cost estimates, but no optimization studies were made. Safety aspects were considered throughout the design effort, bit no formal safety amalysis was completed.

Fued and bhanket salts would be continuously processed in a nearby cell to remove fiscio a products and to recover the bred product. The processing rate would correspond to removal of uranium and protactinium from the bbaket on a 3-day cycle and rare-enth fission products from the core on a 60-day cycle. Since no conceptual desions for the chemical phat were completed, cost eatimntes conld not be on 2 definitive basia. The tentatively estimated fuel cycle cost is about 0.5 mill/kwhr, which includes the fixed charges and operating costs for the processing equipment, the fuel inventory charge, and the credit for bred fuel. Graphite replacement costs, which are not inclucied, would add abont 0.2 mill/kwhr.

The tentatively extimated total construction cost of a 1000-Mw(e) MSBR station, based on the early 1968 value of the dollar, is about $\$ 141$ per kilowatt. The power production cost for a privately owned itation, based on fixed charges of $13.7 \%$ and $80 \%$ plant factor. is about 4 milla/kwhr. The net theraval efficiency of the plant would be about 14.9\%.

The offens, fuel processing, afterheat removal, and maintenance systems needed further investigation at the time the study was suspended, and the limited perfor-siace of the graphite undoubtedly reatricts the design and imposes a maintenance penalty, but the study did not disclose any aspects which indicated that major technological discoveries wouid be required to desizn a twofluid molten-salt reacter power station. The major concern was whether mechanical faiture of gruphite tubes in the reactor core would cause the effective lifetime of the core to be simificantly les than the eight years imposed by the effects of irradiation on the graphite. 


\section{INTRODUCTION}

The basic objective of the Moltensalt Reactor Mogrem is to develop the technology for economical nuclear power reactors that make use of fluid fuels which are solutions of fissile and fertile materials in suitable carrier alts. A major goal is to achien: a thermal breeder reactor based on the tionium- $2: 3 \mathrm{U}$ fuel cycle that will produce power at low cost while conserving and extending the nation's fiuel resources.

Conceptual design studies of a variety of molten-salt breeder reactors for large plants are an important part of this program. In Augist 1966 pulliched a surypy report, ORNL-3996, ${ }_{3}^{1}$ in which we described briefly the status of molten ralt reactor technology and the designs of reactors and fuel processing facilities for $1000-\mathrm{Mw}(\mathrm{c})$ power stations. This survey led us to conclude that the two-fluid reastor which separates the fuel and blanket salts held the most promise for development as a breeder reactor. The modular version, consisting of four reactor modules and asscciated intermediate syetems supplying steam to one turbine-generator, was selected for more detailed analysis.

The study of the modular design of a 1000-Mw(e) plant was begun in the fall of 1966, and some of the results were published in the MSRP progress reports, ORNL-4037,,$^{2}$ ORNL 41 19, ${ }^{3}$ and ORNL-419i. Much of the effort was spent on designs for the core and in exploring the effects of radiation-induced damage to graphite on the core designs. The plant layou, the cell designs, the drain tank systems, the nuclear characteritics, the maintenance, and the cost estimates were also examined in more detail than had been possible in the entier survey.

Considerable progress had been made in these studies when, in August 1967, encouraging information ob-

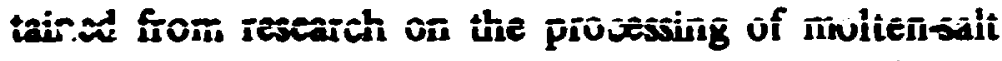
fuels indicated that protactinium and some fission products could be separa'sd from the uranium-andthorium-containing fued salt of a on-fluid reactor by reductive extraction into liquid bismuth. At about this same time, nuclear calculations indicated that a conversion ratio greater than 1 could be achieved in a

\footnotetext{
${ }^{1}$ Paul R. Karten, E. S. Bettis, and Roy C. Robertson, Dexign Studies of 1000-Mw(e) Moltensalt Breeder Reactors, ORNL3996 (August 1966).

${ }^{2}$ MSR Program Semiann Prog. Rept. Aug 31, 1966, ORNL-4037.

${ }^{3}$ MSR Progam Semionn Bros. Rept. Feb. 28, 1967, ORNL4119.

4MSR Program Semiann Prog. Rept. Aug 31, 1967, ORNL-4191.
}

one-fluid reactor of acceptable dimensions by increasing the fuel-salt-to-graphite ratio in the outer regions of the core. The one-fluid breeder is mechanically simpler tinan the two-fluid breeder because it involyes only one salt stream, which contains both the fissile $\left({ }^{33} \mathrm{U}\right)$ and the fertile (thorium) constituents. Also, the one-fluid breeder is a direct descendant of the one-fiuid MolteriSalt Reactor Experiment, which has operated well at Oak Ridge Nationsl Laboraiory. Tite attractive possibility of being a bie to progress in a direct path from the MSRE to large thermal breeder reactors of similar design led us to set aside thi studies of two-fluid

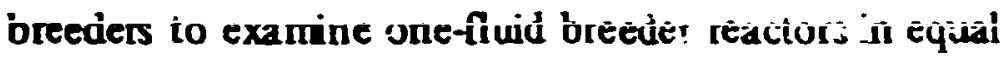
detail. Tre studies of the one-fluid breeders were begun in September 1967 and are continuing.

Although the onefluid breeder bas the desirable features meationed above, the fact remains that the two-fluid MSBR is inherently capable of achieving a sugnificantiy higher breeding performance. This feature alone will sustain intisest in the two-ifuid system. It is inus important io docurrent the riogress made in the two-fluid breeder stuidy before it was set aside. Presenting this information adequately is difficult, beciuse sereral months of studies of the one-fluid reactor have hanged some of our ideas about MSBR design, and new data relevant to the two-fluid reactcr have continued to come from the research and development prcgram. For example, the physical properties of the salts have a profound influence on the design, yet many of these properties are under continuous study and adjustment. Some of the new information will be merationed briefly, but the reader should understand that this report does not fully represent current ideas and that some designs and conceptual drawings presented here woula be considerably altered ir they were to be reexamined on the basis of today's knowledge.

The studies upon which this report is tased involved personnel from almost ail the divisions of ORNL, but particularly those from the Reactor Division, Reactor Chemistry Division, Cremical Technology Division, the Metals and Ceramic Division, and the General Engineering Division. A group composed of members of these divisions, under the leadership of E. S. Bettis, provided the conceptual designs and data vhich are basic to the report.

\section{RÉSUME OF DESIGN CONSIDERATIONS}

Several basic considerations influenced our choice of a two-fluid MSBR concept and many of the details of the plant design. They are reviewed here to provide the 
reader with a better understanding of the dwsign that evolved.

A simplified diagram of a two-tluid breeder reactor is shown in Fig. 2.1. The core of the reactor consisis of an array of 'ubular graphite elements in the center of the reactor vessel. A molten fuel salt is recirculated through the graphite elemenis and through a shell-and-iube heat exchanger by means of a centrifugal pump. A molten blanket salt is similarly recirculated through the space around and between the graphite pieces in the reactor vessel and through an external heat transport circuit. Heat generated in the reactor is transferred from the fuel and blanket salts to a coolant salt in the heat exchangers. The ccolant sait is recirculated through steam generators where the energy is used to convert the feedwater into superheated steam that drives a conventional turtinegenerator to produce electricity.

The MSBK is a thermal breeder reactor that is intended to attain the highest breeding performance consistent with producing power at low cost. Our past studies have indicated that a good measure of the performanct of a breeder system is the total quantity of fissionable material that must be mined in order to provide the fissile inventory fo: a large nuclear power system. This tocal ore requirement should be low. The terms that describe the performance vary wits the assumed growth rate of the nudear electrica! industry and the types of reactors that precede and accompany the breejers, but in the range of interest the performance of a breeder is approximately proportional to the product of the breeding gain $G$ and the reciprocal of the square of the specific inventory, $i / S^{2}$. The "conservation coefficient" $G_{/} / S^{2}$ for MSBR's $\mathrm{min}$ be expected to be in the range of 0.02 to 0.10 , where the

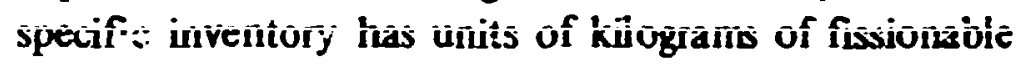
materiai per megawatt of electricily and the breeding gain is dimensionless.

A practical thermal breeder reactor can only be fueled on the thorium- ${ }^{23} \mathrm{U}$ cycle, and it has a small potential breeding gain. Tupically, $\eta$ for an MSBR is 2.22 neutrons produced per neutron zbsorbed in fissile material that is an equiliurium mixture of ${ }^{233} \mathrm{U}$ and

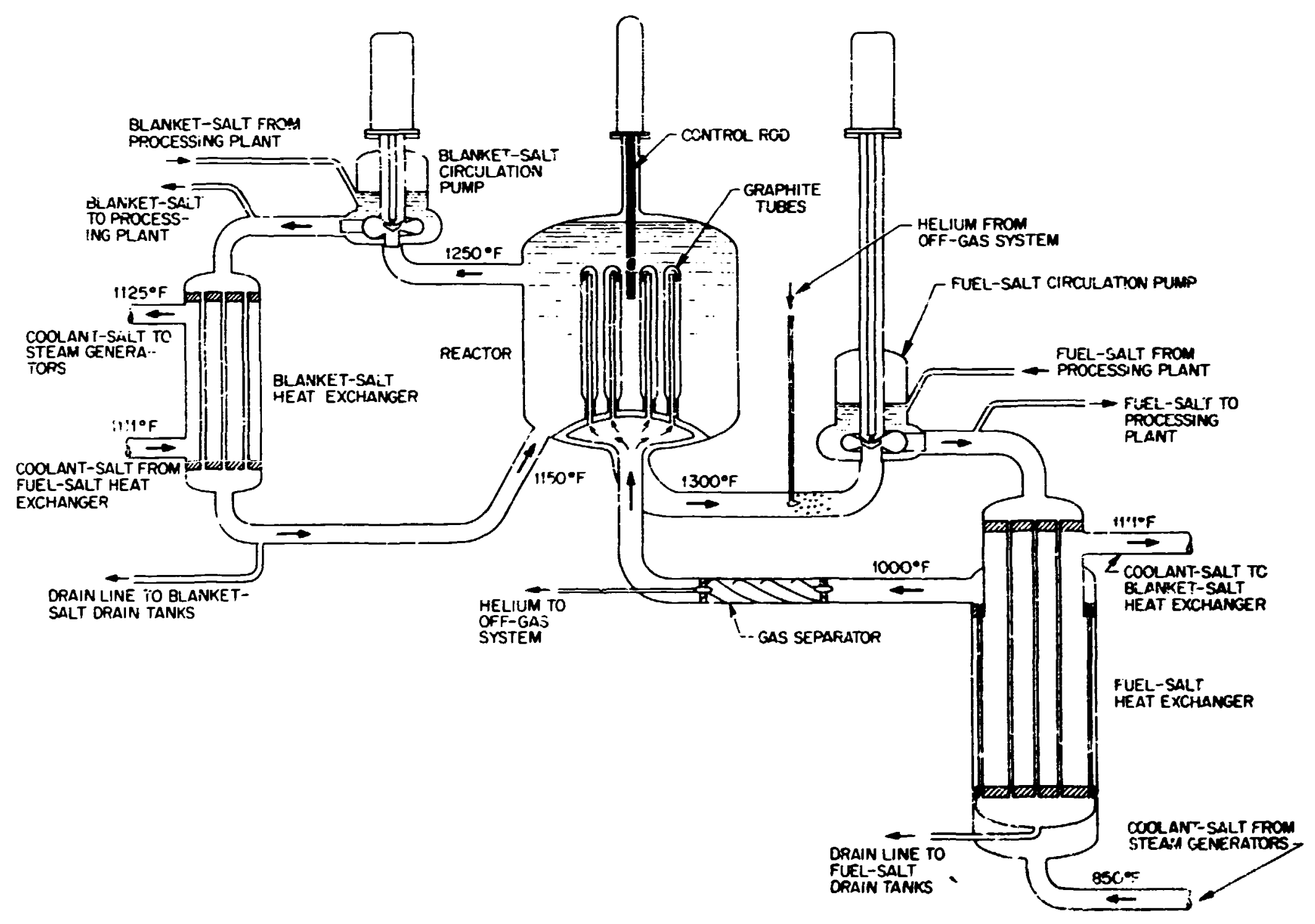

Fig. 2.1. Simplified Flow Dingram of Two-7 laid MSBR. 
23:U. Absorption of one neutron in fissile material and one in fertile material ieaves 0.22 of a neutrun for losses to moderator, carrier salt, leakage, higher isotopes, protactinium, fission products, and structural ma. terials and for absorption in thorium to produce the gain in ${ }^{233} \mathrm{U}$.

Achieving high performance in a breeder depends on keeping the parasitic absorption o.' neutrons and the specit:- inventory of fissile material low. Losses to carrier salt, inoderat $c_{i i}$, and structural materials and the rate and cost or processing to keep the fission croduct losses low all decrease with increasing concentration of uranium in the fuel salt and increasing in veritory in the restor core. The specific inintonty, howevei, inciudes the iventory in the heat transfer equipment external to the reactor vessel, in storage, and in the fuel processing plants, so that the specific inventory and the total inventory cost inciease rapidly with increasing concentration of uranium in the fuel salt. The breeding gain and specific inventory must be balanced to obtain the highest breeding performance (large $G / S^{2}$ ) that is consistent with producing power at low cost.

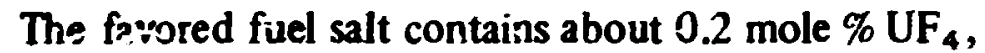
of which about $70 \%$ is ${ }^{23}{ }^{33} \mathrm{U}$ and ${ }^{235} \mathrm{U}, 23 \%$ is ${ }^{234} \mathrm{U}$, and $7 \%$ is ${ }^{236} \mathrm{U}$. The uranium fluoride is dissolved in a ${ }^{7}$ LiF-jeF $_{2}$ (67.33 mole \%) carrier salt. As shown in Trinle 3.1 , this salt has a liquidus temperature of about $840^{\circ} \mathrm{F}$ and good flow and heat transfer properties at the working temperatures. It also has excellen' thermal and radiation stability and, with the use of ${ }^{7} \mathrm{Li}$, a low cross section for the parasitic absorption of neutrons. A $\mathrm{ThF}_{4}{ }^{7}{ }^{7} \mathrm{LF}-\mathrm{BeF}_{2}$ salt $: 7.71-2$ mole $\%$ ), which melts at about $1040^{\circ} \mathrm{F}$, is a good choice for the blanket salt. The physical properties of this salt are also shown in Table 3.1.

Although lithiun and beryllium nuclei are good moderators for neutrons, the moderating properties of the fluoride salts are not sufiiciently good, when compared with their neutron absorbing properties, to build a thermal breeder without the use of other moderator. Graphite is the best material for this purpose, because it has good moderation properties, a low neutron absorption cross section, and good strictral properties at high temperature and can be used in direct contact with molten fluoride salts.

The design and performance of the reacior depend considerably on the effects of fasi ueutrons on the graphite. Neutron irradiation causes graphite to change dimensions and its physical properties to deteriorate. The life of the graphite is expectes to be limited to some to $d$ ! exposure to fast neutrons an $i$ therefore to vary inversely with the maximum power density in the core. Selection of a design power density for the core must be based on a balance between the costs of fuel inventory, periodic replacement of the graphite, and other factors that reflect on the net cost of the electricity produced.

In order for the graphite to have an acceptable radiation life, we estimate that the maximum power density shou'd not exceed about $100 \mathrm{kw}$ per liter of core vulurse. With this limit on power density, the core of a central-station power reactor would have a volume of several hundred cubic feet. This size is too large for the core to ccnsist of graphite bars and highly enriched fuel salt contained in a thin metal shell and surrounded by a region of bianket sait. The critical concentration of ${ }^{233} \mathrm{U}$ in the fuel salt would be so low that the absorptions in the carrier salt and the graphite would be excessive. Absorption of neutrons by the shell would further degrade the performance.

The concentration of ${ }^{233} \mathrm{U}$ in the fuel salt can be raised to the desired level by dispersing blanket salt throughout the core. This is accomplished by making the graphite moderator in the form of tubriar elements and flowing the fuel salt through the elements and the blanket salt around the elements. The core composition is obtained by optimizing the relative volumes of fuel salt, blanket salt, and graphite within bounds imposed by limits on the concentration of thorium in the blanket sait and by the engineering of the core.

Results of many cal:ulations have shown that the combined neutron losses to fuel and blanket carrier salts, the graphite moderator, and higher isotopes will be near 0.11 in an opinived ieact:e, !eaving 0.11 for other losses and the breeding gain. Leakage losses are reduced to a small amount by a thorium blanket of reasonable thickisess around the core. The losses due to protactinium are kept small by keeping its concentration in the blanket salt low. This is accomplished by having a blanket of large volume at low neutron flux or by removing the protactinium from the blanket salt on a few-day cycle and allowing it to decay in the processing plant. Xenon-135 must be removed from the fuel salt on a few-second cycle, or the surfaces of the graphite elements must be sealed to greatly reduce the rate of diffusion of xenon into the pores. Most of the other fission products must be removed by processing the fuel salt on a 30- to 50-day cycie. Limiting the toial

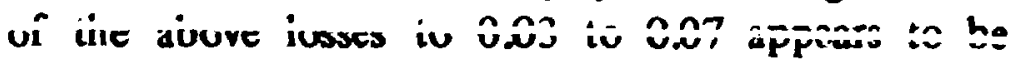
reasonable; this leaves a potential breeding gain of 0.04 to 0.08 .

$A$ reactor with a breeding gain in this range and a specific inventory of $1.5 \mathrm{~kg} / \mathrm{Mw}(e)$ or less will have good breeding performance. In order to have this low a 
specific inventory, the $25 . \mathrm{u}$ unt of ${ }^{233} \mathrm{U}$ external to the reactor core must be kept to a minimum. The heat transfer circuit of the reactor must be closely coupled to the reactei ressel, and it musi ha 'e high performance. The îssile inveniory in the biariliet systems must be kept small by extracting the bred ${ }^{233} \mathrm{U}$ from the blanket salt on a few-day cycle and naking it available for adding to the fuel salt to compensate for burnup. Processing the fuel and blanket sal's at the reactor site is necessary to avoid inventory in ransport and storage, and thort cooling time is impo tant in ic firsing the inventory in processing. The processes must be simple and involve few changes in the physical or chemical nature of the salts if they are to be carried out rapidly and inexpensively. Fluorination to remove the uranium as the volatile $\mathrm{UF}_{6}$ followed by vacuum distillation to separate the carrier salt from the rare-earth fission products satisfies these requirements for processing the fuel salt. Fluorination to remove the uranium or extraction of protactinium and uranium into molten bismuth can satisfy the requirements for the blanket.

With thorium blanket salt dispersed throughout the core, the breeding gain is bargely independent of the size of the core, but this arrangement imposes several conditions on the design. The first of these is that graphite elements must be joined to metal-piping in the reactor vessel. A perfect separation between the fuel and blanket salts is not essential to the safety of the operation, but the leakage must not be so great as to put an excessive burden on the processing facilities. Processing considerations iead to a preference for any leakage to be blanket salt into fues zalt, and the leakage must be kept below about $1 \mathrm{it}^{3} /$ day in a 1000-Mw(e) plant. Such a plant would have several hundred graphite-to-metal joints. Our experience led us to choose graphite-to-metal brazing as the method for obtaining adequate leak-tightness.

The graphite elements for the core must be of a size and shape that are wi'inin the capability of manufacturers to make and inspect for reasonable cost and with good qualicy control. Isotropic material appears desirable and may be essential from the standpoint of irradiation effects. Thicknesses of sections must be limited so that the temperature rise due to heating in the graphite is not large. Effects of irradiation increase with temperature, and stresses increase with temperature difference, so a large rise in internal temperature couid result in a large decrease in service life of the core clements. Glaphite tubes 6 in. or less in diameter and with a wall $3 / 4$ in. or less in thirkness appear to fulfill all these requirements.
Neutron irrodiation produces substantial changes in lengih of the graphite elements, and the difference in expansion of the graphite and the metal parts of the reactci vessel with temperature shanges can also be large. These effects must be accommodated without overs'ressing the graphite. We propose to accomplish this iy makin the graphite elements in the form of concentric tubes connected to the reactor vessel at only one end in order to provide freedom for axial expansion and contraction. The fue! salt would flow in and out at the same end of the elements, and the connections would be to tube sheets at the bottom of the reactor vessel to allow the salt to drair completely.

Because of the irradiation effects, the graphite tubes will have to be replaced periodically. Also, one could expect an occasional failure of a graphite element or a graphite-to-metal joint from other auses. The reactor vessel and internals will be highly radioactive after a short time at high power, and with the graphite elements brazed to a tube sheet in the botton of the reactor vessel, individual tubes could not be readily inspected or replaced. We concluded that the most practical way to renew the graphite in the core would be to replace the entire raactor vessel and its contents. Suitable provisions would be required for iemotely operated tools and viewing equipment to cut, weld, and inspect joints in the piping system. Provisions for handling and disposing of spent reactor vessels would have to be included in the plant.

The high melting temperatures of the salts make it necessary to preheat the reactor equipment to ibgh temperature before introducing the salts and to maintain the temperature when they are present. The special problems of maintenance and inspection of the reactor equipment after it has become radioactive led to our proposals to install the reactor systems in heated cells, which are comparable to large fursaces, rather than to apply heaters and insulation to the vesseis aniu piping.

In our studies of designs for molten-salt breed(x reactors, we are concerned primarily with power st1tions having outputs of $1000 \mathrm{Mw}(\mathrm{e})$ or more. The capacities of salt circulation pumps, heat exchangers, steam generators, etc., needed for such plants are greater than could reaconably be designed into single units. In the 1000-Mw(t) MSBR design described in ORNL-3996, ${ }^{1}$ we chose to connect four primary heat removal circuits to one reactor vessel, to provide vine coolant and steam generator circuit for each primary heat removal circuit, and to send the stcam from all the steam generators in the plant to one turbine. 
Since the two-fluid breeder has a blanket of low ${ }^{233} \mathrm{U}$ and high thorium content around the core to capture the leakage neutrons, reactors of this type can have about the same breeding performance over a wide range of size if the maximum power density in the core is held constant. These facts, together with the special problems and time required to replace a reactor vessel, led is to consider a modular design for the two fluid MSBR in which separate, but smalier, reactor vessels would be coupled to primary heat removal circuits to provide four autonomous reactor systems delivering steam to one turbine-generator. This modular plant would be slightly larger than the integral n!ant, since four small reactor vessels with associated conirol systems would be substituted for the single larger vessel. Otherwise the equipment in the plant would be the same. The advantage would be that the plant could continue to operate at part load whise one or two modules were down for maintenance. We were sufficiently impressed by this capability to make the modular concept the basis for the design studies described in later sections of this report. No analysis was made of the optimum size for a mudule. We simply decided for the purposes of this study to provide four modules in our 1000-Mw(e) plant.

All our designs for MSBR plants have fuel and blanket circulation systems that are separited from the steam systen by an intermediate coclant system. If the steam system were coupled directly to the fuel salt system by means of a steam generator, any leaks in the tubes of the steain generator would result in steam or weter leaking into the fuel salt. Reactions between water and fuel salt would not be violent, but corrcsive hydrogen fluoride would be generated, and uranium oxide would precipitate in the salt. Also, special provisions would have to be included in the design to prevent the fuei circulazion system from being raised to the high pressure of the steam system. Molten sodi'ım, helium, and other coolants have been considered for use in the coolant system, but we prefer a molten salt. Sodium reacts with the fuel salt to generate considerable heat, precipitate uranium, and raise the melting point of the salt. Helium does not react with the salt but must be used at high pressure in order to obtain a good heat transfer coefficient in the primary heat exchanger. At best the heat transfer coefficient with gas is considerably less than can be obtained with sodium or salt and results in an undesirably high inventory of fuel salt and fissionable uranium in the reactor system. The ${ }^{7}$ LiF-BeF 2 coolant salt used in the MSKE is a good coolant, but it costs about $\$ 1400$ per cubic font, and its melting point is about $840^{\circ} \mathrm{F}$. We would prefer to have a iess expensive cooling salt with a lower melting point. The salt $\mathrm{NaBF}_{4}-\mathrm{NaF}_{2}(92-8$ mole $\%)$ cos!s oniy about $\$ 60$ per cubic inot, melts at $725^{\circ} \mathrm{F}$, and is a favored candidate for use in: the coolant system.

Minimum operating temperatures for the MSBR are set by the liquidus temperatures of the salts, and the materials of construction are governed by the opcrating temperatires and the properties of the salts. The reacior fuel and blanket systems must be orerated at temp:ratures above about $1000^{\circ} \mathrm{F}$, and the coolant syst':m must be operated above abciut $750^{\circ} \mathrm{F}$. High nick:? allcys have good resistance tc corrosion by fluorde salts at high temperature and good creep streing,th to abou: $1300^{\circ} \mathrm{F}$. Since the temperatuie must be high and the materials are expersive, we believe it appropriate to couple the reactor plant to a steam cycle that is representative of the best current practice. The 3500 -psia, $1000^{\circ} \mathrm{F}$-throttle, $1000^{\circ} \mathrm{F}$-reheat cycle that is presently being specified for most new large fossilefueled plants was selected for use in our design studies largely on this basis. The supercritical cycle has the added advantage that the feedwater to the steam generators could he prehested to $700^{\circ} \mathrm{F}$ without much loss in thermal efficiency by direct injection of superheated steam into the water. This procedure may be necessary if use of feedwater at a more common temperature creates problems in the steam generators by freezing coolant salt on the tubes. (At subcritical pressures the Loeffler rycie employing a steam circulator and mixing drum probably would have to be used to attain the requisite high-iemperature entering stream.)

Finally, it is important to emphasize that the designs discussed here are based largely on cuirent techriology and develonmentis tinat we believe to be readily achiev. able. The materials, processes, and perfonnance factors are developed sufficiently that no mai, $r$ inventions appear to be required to solve the technogical problems.

\section{MATERIALS}

\subsection{General}

This section briefly discusses some of the materials which are unique tc mioitensalt breeder reactors. These inciude the fucl, blanliet, and coolant salts; the reactor graphite; and the Hasta!loy $\mathrm{N}$ used to contain the salts. A brazed joint of graphite to Hastelloy $N$ is also dessribed.

These, or similar, materials have been under study at ORNL for many years, beginning with the ANP 
program in the early 1950's aind continuing through the MSRE program to the present. Specific evidence has accumulater that fluoride sait mixtures containing fissile and fertile materials have the nuclear and physical properties to :riake them suitable for use in a moltensalt thermal breeder reactor. The salts possosi suritable liquidus temperatures and stability to termperature and irradiation. The Hastelloy N, used to contain ine salts, and the graphite, which acts as the moderator, are compatible with each other and with the salts. Except for the graphite, which suffers irradiation damage, theic are no characteristias of the materials which significanitily limit the MSBR in the concept discussed here.

The accumulated background of information on the materials is toi extcisive to be covered fully in this report. References are made, however, to some key reports that contain more complete information or bibliographies.

\subsection{Sâiis}

\subsubsection{General}

iable 3.1 shows the salt compositions and physical pruperties used in the two-fluid MSBE. study. Recently measuitd values of the physical properties are also included where pertinent. (See Sect. 5.6.1 for estimates of volumes of salts in the systems.)

\subsubsection{Fuel Salt}

The fuel salt is a ternary mixture of ${ }^{7} \mathrm{LiF}, \mathrm{BeF}_{2}$, and ${ }^{23}$ ? $\mathrm{UF}_{4}$ (68.5.31.10.2 mole \%). A phase diagram for the system is shown in Fig. 3.1, an.1 the jroperties are given in Table 3.?
Thie itSRE uses essentially the same fuel salt except that it contains 5 mole $\%$ of $\mathrm{ZrF}_{4}$ to eliminate the possibility of precipitating $\mathrm{UO}_{2}$ in the event of accidenta! contamination of the system with oxy'en or wster. The zirconium addition is judged to ue unnecesary for the MSBR in that the MSRE has been operated for four years without contaminating the ficki sa's:, , $^{5-7}$ and the frequent processing of the MSBR fuel stivild keep the oxide sontent low.

The MSPE uata also indicate excellent compatibility of the salt with the Hastelloy $\mathrm{N}$ and graphite materials in the system. The corrosion rate of the metal is less than $0.2 \mathrm{mil} / \mathrm{year}$, and the inechanical properties are virtualiy unaffected by iong exposure to the salt. The graphite is not wetted $b_{j}$, the salt mixture, and bulk permeation by the salt is less than $0.2 \%$, well hol_... iste amount considered acceptable.

As indicated in: $5:$ s. 3.1 , on cooling of the fuel sall in the :iritperature interval from 3 briut $450^{\circ} \mathrm{C}\left(842^{\circ} \mathrm{F}\right)$ to $438^{\circ} \mathrm{C}\left(820^{\circ} \mathrm{F}\right)$. the cumpound $2 \mathrm{LiF} \cdot \mathrm{BeF}_{2}$ precipitates from the melt. At $438^{\circ} \mathrm{C}\left(820^{\circ} \mathrm{F}\right)$ the salt mixture solidifies and produces a mixture of two crystalline phases, 2LiF-BeF 2 (89 wt \%) and LiF.UF, (11\%). On reheating, the mixture resumes its initial composition ard physical properties without change.

A considerable body of information exists to indicate that uite MSRE fuel salt is stable under irradiation and

\footnotetext{
${ }^{5}$ W. R. Grimes, Chemical Research and Development for Moltensalt Breeder Reacturs, ORNL-TM-1853 (June 6, 1967 .

${ }^{6}$ Paul N. Haubenreich and J. D. Engei, -Experience with the Moten-Salt R.men ixperiment," Nud. Appt Technd, etc. (see list of references).

7W. R. Grimes, "MoltenSalt Reactor Chemistry," Nud. AppL

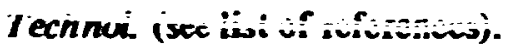

Table 3.1. Physical Properties of Salts for Two-Fluid MSBR ${ }^{a}$

\begin{tabular}{|c|c|c|c|}
\hline & Fuel Salt & Blanket Salt & Coolant Salt \\
\hline $\begin{array}{l}\text { Reference temperature. }{ }^{\circ} \mathrm{F} \\
\text { (unless utherwise noted) }\end{array}$ & 1150 & 1200 & 988 \\
\hline Comrunents & $\mathrm{LiF}-\mathrm{BeF}_{2}-\mathrm{UF}_{4}$ & ${ }^{3} \mathrm{LiF}-\mathrm{ThF}_{4}-\mathrm{BeF}_{2}$ & $\mathrm{NaBF}_{4}-\mathrm{NaF}$ \\
\hline Crinposition, mole? & $68.5-31.3-0.2$ & 71.222 & $92.0-8.0$ \\
\hline Molecular weight, approx & 34 & 103 & 104 \\
\hline Liquidus temperature, ${ }^{\circ} \mathrm{F}$ & 842 & 1040 & $700(725)$ \\
\hline Density, $\rho, \mathrm{lb} / \mathrm{ft}^{3}$ & $127 \pm 6$ & $277 \pm 14$ & 125 (i 21 at $\left.850^{\circ} \mathrm{F}\right)$ \\
\hline Viscosity, $\mu$, ib ft $^{-1} \mathrm{hr}^{-1}$ & $27 \pm 3$ & $38 \pm 19$ & $12\left(4.632850^{\circ} \mathrm{F}\right)$ \\
\hline $\begin{array}{l}\text { Thermal conductivity, } k \text {, } \\
\text { Btu ht } \mathrm{ft}^{-1} \mathrm{ft}^{\circ} \mathrm{F}^{-1}\end{array}$ & $1.5(n .9)$ & $1.5(0.0)$ & $1.3(0.27)$ \\
\hline $\begin{array}{l}\text { Heat capacity, }{ }_{p}, \text { Btu } 1 b^{-1}{ }^{\circ} F-1 \\
\text { Vapor cressure, torrs }(\mathrm{mm} \mathrm{Hg}) \text { at } 1150^{\circ} \mathrm{F}\end{array}$ & $\begin{array}{l}0.55 \pm 0.14 \\
<0 . !\end{array}$ & $\begin{array}{l}0.22 \pm 0.06 \\
\text { S..i }\end{array}$ & $\begin{array}{l}0.14(9.36) \\
\text { to }(252)\end{array}$ \\
\hline
\end{tabular}

The physical properties stiown are those generally in use at ine time the iwo-fluid reacrot sivdy was sel asioe. Values in paren theses are based on current information and are helieved to be more represantaitive. 


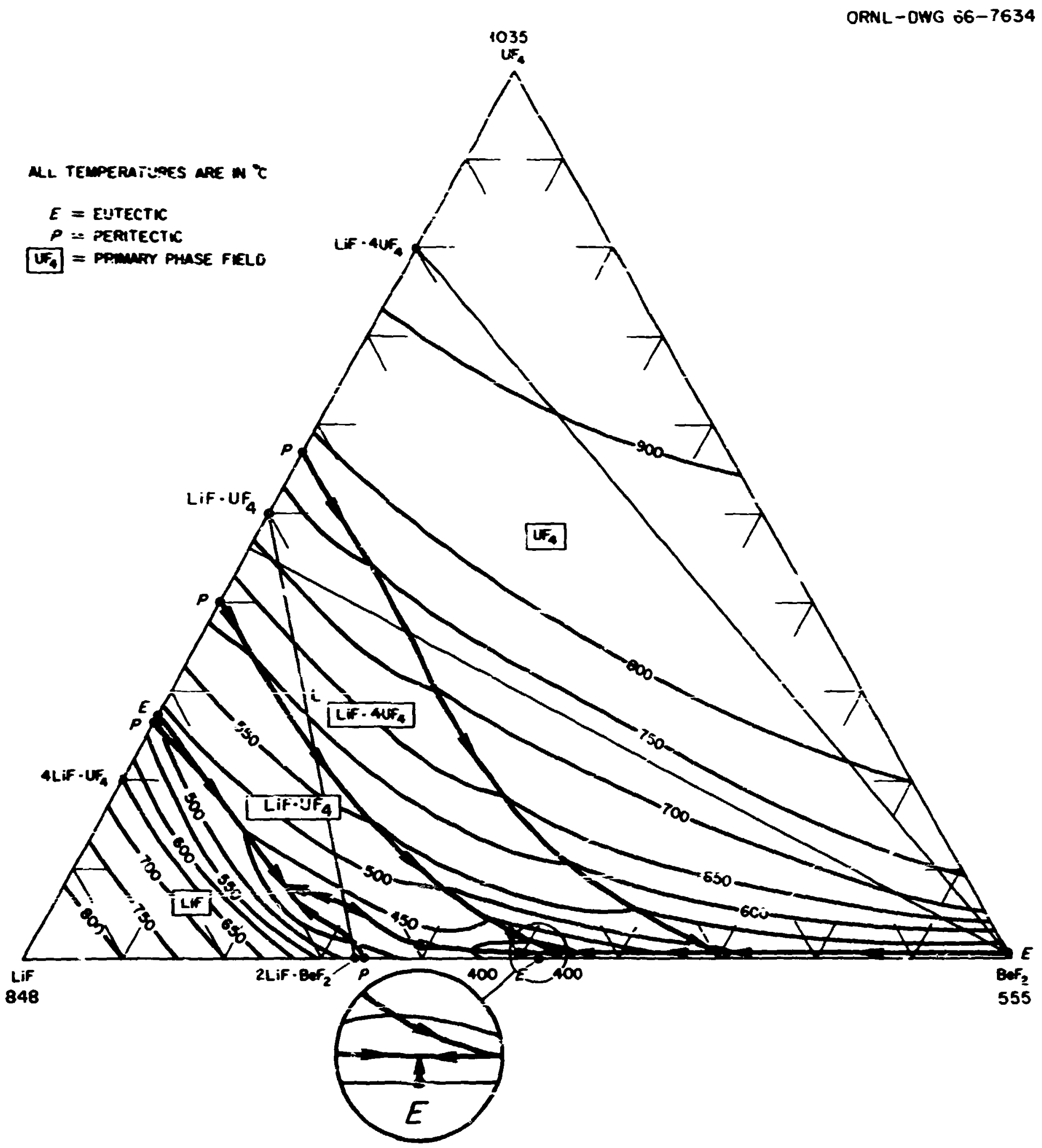

Fig 3.1. Two-Fluid MSBR Fud Salt - The Sysiem LiF-BeF $2-$ UF $_{4}$.

to tempera: treswell above $800^{\circ} \mathrm{C}\left(1470^{\circ} \mathrm{F}\right)$. The MSBR fuel should behave similarly. However, if irradiated salt is allowed to frecze and cool below anout $100^{\circ} \mathrm{C}$ $\left(212^{\circ} \mathrm{F}\right)$, radiolysis occurs with reiease of $F_{2}$. This reaction can be easily suppressed by mainiaining the sait ahove. say, $200^{\circ} \mathrm{C}\left(390^{\circ} \mathrm{F}\right)$.

Fission products will be produced in a $2225 \mathrm{Mw}(\mathrm{t})$ MSBR at the rate of about $2.3 \mathrm{~kg} / \mathrm{day}$. The success of a molten salt reactor as a breeder hinges upon the ability to process the fuel atid blanket salts rapidly enough to maintain the fission proiucts at relatively low leveis and on keeping the costs of this processing low enough to afford attractive fued cycle costs. (The processing azpects are more fully discussed in Sect. 4.4.) Even with rapid processing, however, the fission product concentrations are high encigin to cause their behavior in the salt to be of interest. 
Table 3.2. Approximate Fission Product Distribution in MSRE After 32,056 Mwhr of Operation

\begin{tabular}{|c|c|c|c|c|c|}
\hline Isotope & $\begin{array}{l}\text { Inventory } \\
\text { in MSRE } \\
\text { (disimin) }^{a}\end{array}$ & $\begin{array}{l}\text { Percent in } \\
\text { Fuel }\end{array}$ & $\begin{array}{l}\text { Percent on } \\
\text { Graphite }^{b}\end{array}$ & $\begin{array}{c}\text { Percent on } \\
\text { Hastelloy } \mathbf{N}^{b}\end{array}$ & $\begin{array}{l}\text { Percent in } \\
\text { Cover Gas }\end{array}$ \\
\hline \multicolumn{6}{|c|}{$\times 10^{17}$} \\
\hline${ }^{99} \mathrm{Mo}$ & 7.91 & 0.94 & 10.9 & 40.5 & $? 7$ \\
\hline${ }^{132} \mathrm{Te}$ & 5.86 & 0.83 & 10.0 & 70.0 & 66 \\
\hline${ }^{103} \mathrm{Ru}$ & 3.36 & 0.13 & 6.6 & 14.9 & 40 \\
\hline${ }^{95} \mathrm{Nb}$ & 4.40 & 0.044 & 36.4 & 34.1 & 5.7 \\
\hline${ }^{95} Z_{r}$ & 6.00 & 96.1 & 0.03 & 0.06 & 0.14 \\
\hline${ }^{85} \mathrm{Sr}$ & 5.02 & 77.0 & & 0.26 & $33^{c}$ \\
\hline $13 i_{1}$ & 4.00 & 64.0 & & $1.0^{a}$ & $16^{a}$ \\
\hline
\end{tabular}

aTotal inventory calculated from the power history of the MSRE.

${ }^{b}$ Values for graphite and metal are based on the amounts found on specimens removed from the core, and the vahues for the cover gas are based on samples of gas obtained from the pump bowl.

CProduced by decay of ${ }^{89} \mathrm{Kr}$ in cover gas.

${ }^{d}$ Produced by decay of ${ }^{131} \mathrm{Te}$.

Data obtained from the MSRE have confirmed the chemists' predictions regarding the state of the fission products in a moltensalt reactor. The rare gases krypton and xenon are only sightly soluble in the hightemperature salt and are readily removed by sparging the salt with helium bubbles. Rubidiurn, cesium, strontium, barium, zirconium, yttrium, and the lanthanides form very stable fluorides, which are found primarily in the salt. Some of these elements, such as rubidium and cesium, have gaseous precursors and appear in the graphite and the off-gas system in proportion to the amounts of the precursors that escape from the salt. The more noble metals from elements 41 and 42 (niobium and molybdenum) through element 52 (teilurium) are largely reduced to the metallic state in the salt. They deposit on graphite and metal surfaces in the reactor and somewint surprisin ly appear in the cover gas, presumably as a "smoke" of metallic particles. The distribution of representative fission products of this group in the MSRE after 32,000 Mwhr of operation is shown in Table 3.2. A similar distribution, modified to reflect differences in relative surface areas and in flow conditions, must be expected in an MSBR. The data in Table 3.2 and other analyses of samples of salt indicate that iodire forms stabie iodides in the salt. Iorline found on MSRE surfaces and in the cover gas is produced there by decay of the noble metal tellurium. Bromine forms stabie bromides tiat remain in the salt.

\subsubsection{Blanket Salt}

The blanket solt for the two-fluid MSBR is a temary mixture of ${ }^{7} \mathrm{LiF}, \mathrm{BeF}_{2}$, and $\mathrm{ThF}_{4}$ (71-27.2 mole \%).
This system is shown in Fig. 32, and the properties are listed in Table 3.1.

The blanket salt has a liquidus temperature of about $560^{\circ} \mathrm{C}\left(1040^{\circ} \mathrm{F}\right)$, and during solidification the solid phases $\mathrm{LiF}_{\mathrm{T}} \mathrm{ThF}_{4}$ and $3 \mathrm{LiF} \cdot \mathrm{ThF}$, are formed, incorporating $\mathrm{Be}^{2+}$ in both the interstitial and substitutional sites. 5

The blanket salt can be expected to exhibit the same good compatibility with Hastelloy $\mathrm{N}$ and graphite under reactor conditions as does the fuel salt. Capsule tests in the MTR demonstrated the radiation stability of similar salts containing ThF. . Early in the operation of the MSRE there was some discussion of eventually operating with a fuel salt mixture containing thorium, but this is now considered unnecessary since the results are largely predictable.

The blanket salt will be processed on a rapid cycle to remore the bred protactinium and/or fissile material in order to minimize the fissile inventory, the fission rate, and the concentration of fission products in the blanket salt..$^{3}$ The chemical processing is discussed in more detail in Sect. 4.4.

\subsubsection{Coohnt Salt}

In our design of an MSBR, a coolant is used for transporting heat from the primary heat exchangers to the steam generators and reheaters. Characteristics considered to be desirable in the coolant include low melting temperature, compatibility with Hastelloy $N$,

\footnotetext{
${ }^{8}$ W. L. Carter ar.d M. E. Whatley, Fud and Blanket Processing Development for Molrensalt Breeder Renctors, ORNLTM-1852 (June 1967).
} 


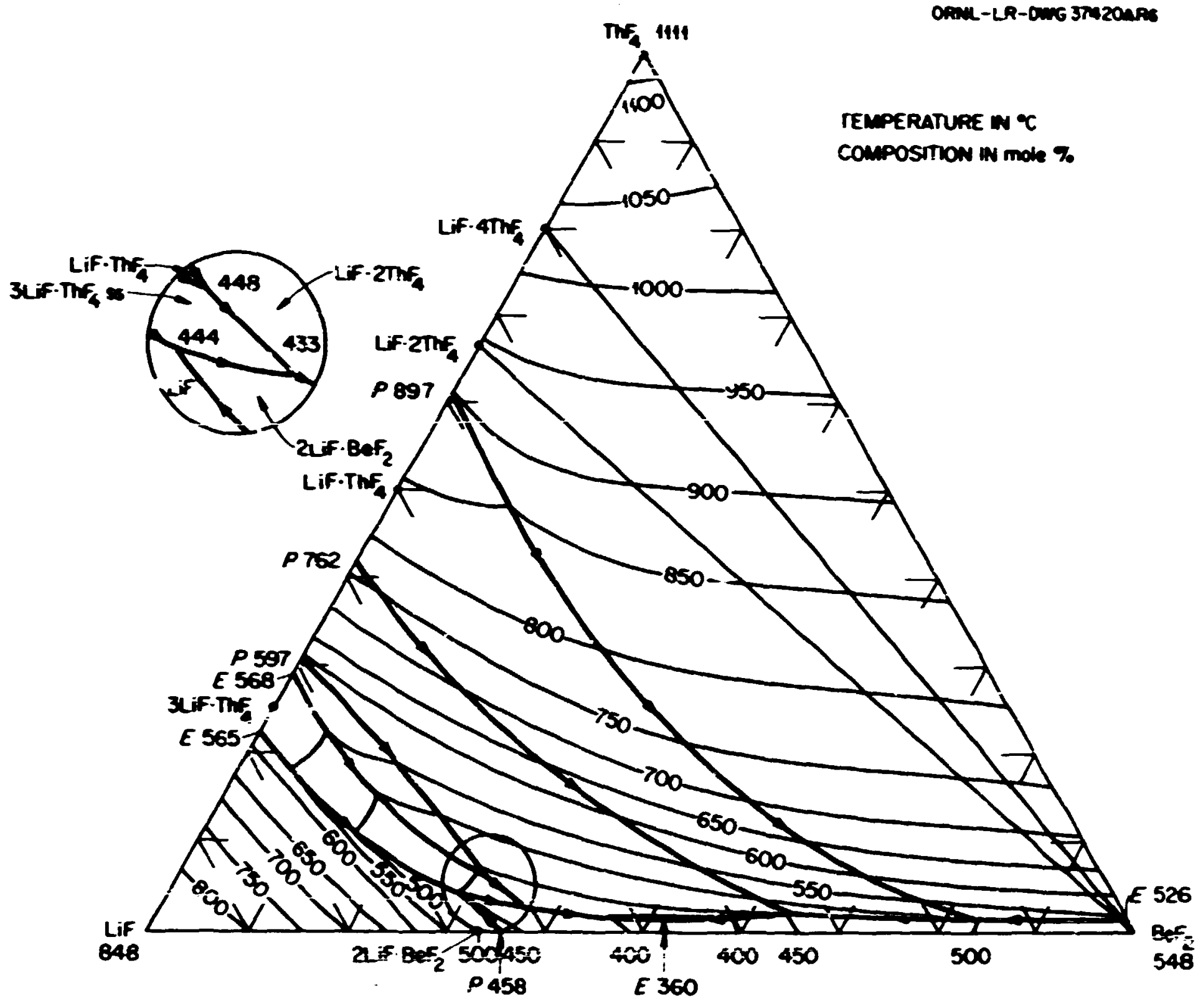

Fis 32. Two-f hid MSBR Baket Salt - The Syctem LF BeF $2-$ MF 4 -

resistance to decomposition by heat and radiation, good heat transfer and pumping characteristics, low vapor pressure at operating temperature, freedom from violent sherisili ienctions with aseociated materials, and low cost. Sndium is undesirable because of its reactivity with air, water, and fud salt. The MSRE coolant, 'LiF-BeF, (66-34 mole \%), has a liquidus temperature near $455^{\circ} \mathrm{C}\left(850^{\circ} \mathrm{F}\right)$ and is more expensive than one would like to use in the large volume of alt MSBR system. Sodium fluoroiorate of the eutectic composition $\mathrm{NaBF}_{4}-\mathrm{NaF}(92.3$ mole $\%$ ) was selected as most nearly satisfying all the requirements for a coolant. The phase diagram for the $\mathrm{NaBF}_{4}-\mathrm{NaF}$ system is showil in Fig. 3.3, and the phyjical properties are given in Table 3.1.

Several mixtures of fliscroborates of the alkali metals were considered in making the selection. Some were ruled out because of high viscosity or high cost.

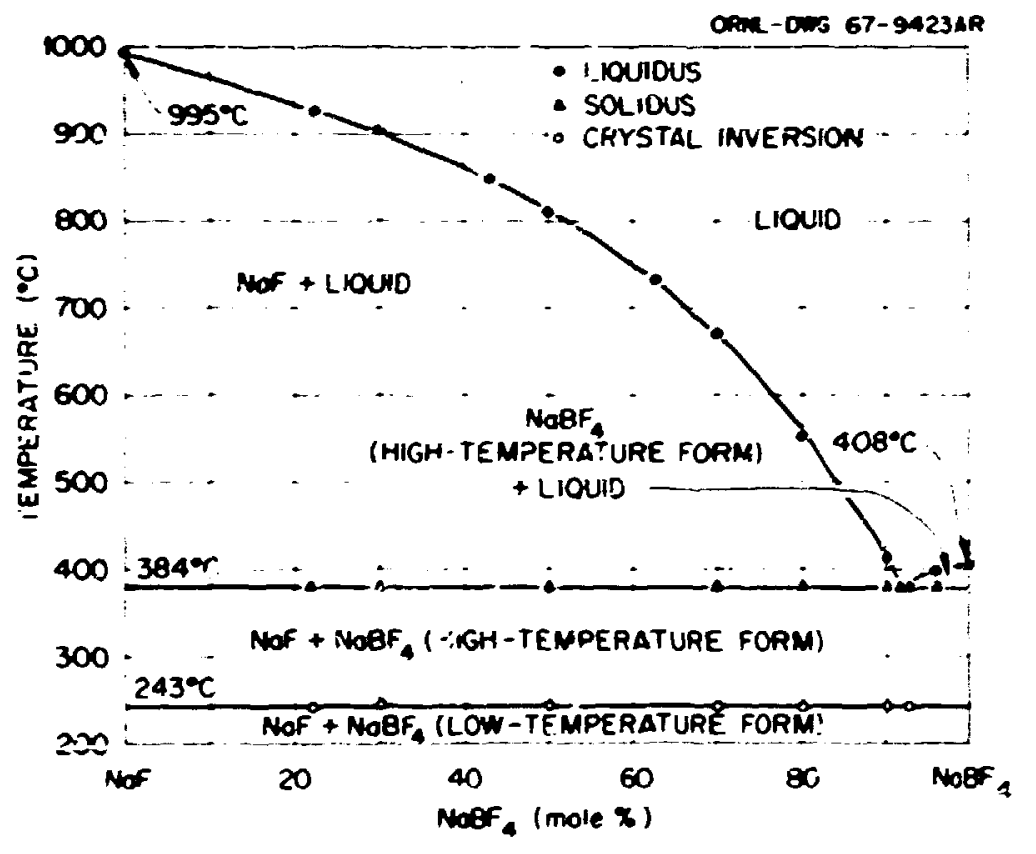

Fi. 3.3. Twofluid MSBR Coolant Sal - The Sydtem $\mathrm{NaF}_{-\mathrm{NaRF}}$. 
Stoichiometric $\mathrm{NaBF}_{4}$ does not exist in the molten state without a wry high martial gresener of RF; The eutectic composition, however, has most of the properties considered desirable for the MSBR coolant, and it can operate with a diute mixture of $\mathrm{BF}_{3}$ in. helium at abour $2 \mathrm{~atm}$ pressure as the cover gas. The melting temperature of about $385^{\circ} \mathrm{C}\left(725^{\circ} \mathrm{F}\right)$ is acceptable. Aithough a iuwar temperature would be desirable, it is not clear at this time whether the liquidus temperature can be successfully depressed by use of additives. The fluoroborate has a modest cost of less than $=\$ / / \mathrm{lb}$, and commercial grades may have

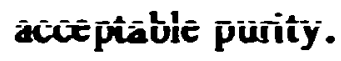

Thermal convection loop studies of the corrosion of Hastelloy $\mathrm{N}$ by sodium fluoroborate at temperatures to $607^{\circ} \mathrm{C}\left(1130^{\circ} \mathrm{F}\right)$ have indicated a low corrosion rate in the absence of sontamination of the salt by moisture, although not as low as with the MSRE coonant. As with other fluoride salts, the presence of insisture greatly increases the corrosion rates. The absence of severe corrosior, problems is confirmed qualitativeiy by experience with the circulation of sodium fluoroborate in a large test loop for about $1800 \mathrm{hr}$. A conosion product precipitate, $\mathrm{Na}_{3} \mathrm{CrF}_{6}$, has been obtained from both types of loops. Its solubility is inferred to be sufficiently low that coid trapping may be required to prevent the naterial from interfering with operation of the coclant system by depositing on heat transfer surfaces and in other cooled regions.

Molten sodium fluoroborate has been irradiated in gamma fluxes as high as $8 \times 10^{7} \mathrm{r} / \mathrm{hr}$ without significant effects on the salt or the Hastelloy $N$ container and specimens. ${ }^{3}$

\subsection{Hastelloy $\mathbf{N}$}

The reactor vessel, piping, and primary and secondary heat transfer equipment require a material that is resistant to corrosion by fluoride salts; compatible with graphite; capable of being fabricated into complicated shapes ky rolling, forging, machining, and welding; mechanically strong and ducale at temperatures up to $700^{\circ} \mathrm{C}\left(1300^{\circ} \mathrm{F}\right)$; and capable of maintaining these properties during long exposure to this elevated temperature in a neutron environnient. Hastelloy $\mathbf{N}$ is the preferred material for this application.

Hastelloy $\mathbf{N}$ is a nickel-base alloy containing chromium for oxidation resistance and molybdenum for strength at high temperature. The "standard alloy" has

\footnotetext{
${ }^{9}$ MSR Program Semiann. Progr. Rept. Feb. 29, 1968, ORNI,4254, p. 180.
}

Table 3.3. Vomina Chemisal Composition of Hexthoy $\mathrm{A}$

\begin{tabular}{|c|c|c|}
\hline Elemerat & 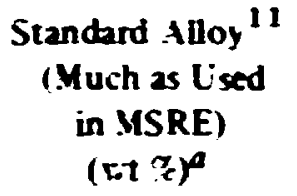 & $\begin{array}{l}\text { Modified Alloy' } \\
\text { Recommented for } \\
\text { MSBR's } \\
\text { (wt q) }\end{array}$ \\
\hline Nickel & Babnce & Babnce \\
\hline Molybden am & $15-18$ & 12 \\
\hline Chromium & $6-8$ & 7 \\
\hline Iron & 5 & $0-4$ \\
\hline Manganese & 1 & $0.2-0.5$ \\
\hline Silicon & 1 & $0.1 \max$ \\
\hline Boron & 0.91 & $0.001 \mathrm{mx}$ \\
\hline Titanium & & $0.5-1.0$ \\
\hline Hafinium or Niobium & & $0-2$ \\
\hline Copper & 0.35 & \\
\hline Cobalt & 0.2 & \\
\hline Phosphorus & 0.015 & \\
\hline Sulfur & 0.02 & 0.35 \\
\hline Carbon & $0.04-0.08$ & \\
\hline Tungsten & 0.5 & \\
\hline Aluminum + Titanium & 0.5 & \\
\hline
\end{tabular}

eSingle values are maximum percentages unless otherwise specified.

the composition shown in Table 3.3 and was developed in the ANP program to contain molten fluoride salts at temperatures to about $870^{\circ} \mathrm{C}\left(1600^{\circ} \mathrm{F}\right)$. The MSRE was constructed of stariciard Hasieilioy iv. The meteriai was obtained from commercial vendors, and it was fabricated using conventional practices comparable with those used for stainless stect. The major material problem encountered was weld cracking, which was overcome by slight changes in the meiting practice and by strict quality control of the materials. Heats of the metal subject to cracking were identified and eliminated by means of a weldability test included as part of the specifications.

Results of extensive corrosion tests, examination of specimens exposed to the fuel sait in the center of the core of the MSRE, and analyses of samples of fuel salt from the MSRE have derronstrated the excellent resistance of Hastelloy $\mathbf{N}$ to corrosion by fluoride salts. If the salt is kept slightly reducing and is not continually contaminated by oxygen or moisture, the corrosion rate at temperatures to $700^{\circ} \mathrm{C}\left(1300^{\circ} \mathrm{F}\right)$ is less than $0.5 \mathrm{mil} / \mathrm{year}$. The effect of the cor esion is to gradually deplete the alloy of chromium, learing behind the major constituents and, at higher temperatures, a network of subsurface voids.

Irradiation of the standard Hastelloy $\mathbf{N}$ by thermal neutrons drastically reduces the ductility and stress rupture life of the metal at high temperatures. This 
Table 3.4. Physical Properties of Hadelloy N

\begin{tabular}{|c|c|c|c|c|c|}
\hline & $80^{\circ} \mathrm{F}$ & $500^{\circ} \mathrm{F}$ & $1000^{\circ} \mathrm{F}$ & $1300^{\circ} \mathrm{F}$ & $1500^{\circ} \mathrm{F}$ \\
\hline $\begin{array}{l}\text { Density, ibjim }{ }^{3} \\
\text { Density, Bb/ft }\end{array}$ & $\begin{array}{l}5.3200 \\
553.0\end{array}$ & & & & \\
\hline Thermal conductivity, But hr ${ }^{-1} \mathrm{ft}^{-10} \mathrm{~F}^{-1}$ & 6.0 & 7.8 & 10.4 & 12.6 & i4.1 \\
\hline Specific heat, Btu $t^{-1}{ }^{0} F^{-1}$ & 0.098 & 0.104 & $0.115^{e}$ & $0: 36$ & 0.153 \\
\hline $\begin{array}{l}\text { Coefficient of thermal expansion per }{ }^{\circ} F^{b} \\
\text { Modulus of elasticity, lb/in. }{ }^{2}\end{array}$ & $\begin{array}{l}5.7 \times 10^{-6} \\
31 \times 10^{6}\end{array}$ & $\begin{array}{l}7.0 \times 10^{-6} \\
29 \times 10^{6}\end{array}$ & $\begin{array}{l}8.6 \times 10^{-6} \\
27 \times 10^{6}\end{array}$ & $\begin{array}{l}9.5 \times 10^{-6} \\
25 \times 10^{6}\end{array}$ & $\begin{array}{l}9.9 \times 10^{-6} \\
24 \times 10^{6}\end{array}$ \\
\hline Electrical resistance, microhm-cm & $120.5^{\circ}$ & 123.7 & 125.8 & $126.0^{\circ}$ & $124.1^{2}$ \\
\hline Apprcximate tensile strength, psi & 115,000 & 106,006 & 95,000 & 75,000 & 55,000 \\
\hline Maximum allowable stress, psir & 25,000 & 20,000 & 17,000 & 3500 & \\
\hline $\begin{array}{l}\text { Maximum allowable stress, psi (bolts) } \\
\text { Melting tempenture, F }\end{array}$ & 10,000 & 7700 & $\begin{array}{l}6600 \\
2470-2555\end{array}$ & 3500 & \\
\hline
\end{tabular}

Taken directly from ref. 10. All other values found from interpolation of plots of ref. 10 data. See this reference for more precise information.

${ }_{\text {B }}$ verage coefficient of expansion over 212 to $1832^{\circ} \mathrm{F}$ lange is $8.6 \times 10^{-6} \mathrm{per}{ }^{\circ} \mathrm{F}$.

CRef. 11.

deterioration results from the transmutation of ${ }^{10} \mathrm{~B}$ to hthium and helium, with the latter collecting in the grain boundaries to promote intergranular cracking. The imadiation effects become appreciable at a fluence of about $10^{18}$ neutrons $/ \mathrm{cm}^{2}$. At $650^{\circ} \mathrm{C}\left(1200^{\circ} \mathrm{F}\right)$ and with stresses above 20,000 psi, metal irradinted to fluences above $5 \times 10^{19}$ can fracture with an elongation less than $0.5 \%$ and with less than $1 \%$ of the life of unirradiated metal. Theoretical considerations and some data indicate that the effecte decrease with decreasing stress. 10 The damage occurs even though the boron content of the alloy is as low as 1 ppm. It is, thereîuic, not practical to limit the radiation effect by control of trace amrounts of boron.

Because the MSRE waz intended to opteraić fôr oniy a few years, the standard lastelloy $N$ was an acceptable material of construction. A material with greater resistance to radiation effects is, hover:er, required for those parts of an MSBR that are subjected to neutron irradiation. Marked improvement in the properties of irradiated Hastelloy $\mathbf{N}$ has been achieved ty adding small amounts of titanium and/or hafnium or niotium to a sligitly altered base material tc obtair modified Hastelloy $\mathbf{N}$ of the range of compositions shown in Table 3.3.

The stress rupture life and the ductility of modified Hastelloy $\mathbf{N}$ can vary considerably with variations in treatment and in amounts of some minor constituenis. In general, we have found that irradiation decreases the rupture life and ductility of the modified alloy, but, for irradiation to fluences of about $10^{21}$ neutrons $/ \mathrm{cm}^{2}$

\footnotetext{
${ }^{\circ}$ H. E. McCoy, Jr., and J. R. Weir, Jr., Materials Development for Molten-Salt Breeder Reactors, ORNL-TM-1854 (J une 1967).
}

(fast and thernini) st temperatures to $750^{\circ} \mathrm{C}\left(1380^{\circ} \mathrm{F}\right)$, its properties are about equal to these of the standard aloy when unirradiated. On this basis and in the assumption that the reactor equipment would be made of modified histelloy $N$, we used the extensive data in the properties of unirradiated Hastelloy $\mathbf{N}$ in our studies of designs for the reactor equipment. Those properties are reported in Table 3.4.

The specific heat, dectrical resistivity, and thermal conductivity data all show inflections with respect to temperature at $650^{\circ} \mathrm{C}\left(1200^{\circ} \mathrm{F}\right)$. This is thought to be due to an order-disorder reaction. No changes in the mechanical properties are detectable as a result of this reaction, however. The alloy has greater sirength than the austenitic stainless steels and is comparable with the stronger alloys of the Hastelloy type. The maximum allowable stresses shown in Table 3.4 were established hy performing mechanical properiy tests on experimental heats of commercial size. The data were reviewed by the American Society of Mechanical Engineers Boiler and Pressure Vessel Code Committee, and the stress values were approved for use under Case 1315 for Unfired Pressure Vessels and under Case 1345 for Nuclear Vessels. ${ }^{11}$

\subsection{Graphite}

The characteristics desired of the moderator matcrial for the core of a two-fluid MSBR corcept are good neutron moderation, low neutron ansorption, compatibility with the molten fuel and blanket salts and

\footnotetext{
I' American Society of Mechanicai Engineers, Boiler and Pressure Vessel Code, jintisn VIII. Infired Pressure Vessels, Case 1315, and Nuclear Vessel Construction, Lase i:45.
} 
with Hastelloy $\mathbf{N}$, sufficient strength and integrity to separate the fuel and blanket salts with good reliability, low permeability to salt and gases, fabricablity at reasonable cost, capability for being joined to ítastelloy $\mathrm{N}$, and finally, ability to maintain all the desirable properties after exposure to operating temperatures as high as shout $1400^{\circ} \mathrm{F}$ and to neutron fluences above $10^{23}$ neutrons $/ \mathrm{cm}^{2}$ (for $E>50 \mathrm{kev}$ ). In order to obtain these characteristics a sparial grade of coated graphite will have to be developed specifically ici MSBR use.

The chemical purity and neutror perisrmance, compatibility with materials, salt perneability, and sisength characteristics are sufficient in surrently available graphite. Prelininary experinents indicate that a surface impregnation can be developed to keep the gas absorption within acceptable limits. The effect of neutron irradiation, however, is :o first shrink and then swell the grafhite to cause an increase in porosity and, we expect, a deterioration in physical properties. The dimensional changes occur sowly, and their effects on the neutronics of the reactor can be accommodated by gradually adjusting the fuetsalt composition, although at a small detriment to the nuclear performance. The radiation damage to the graphite, however, limits the iseful life of the reactor core. Increases in cost that result from more irequent replacements of the gaphite at higher poiver densities must be balanced against the cost saving obtained from higher power density to obtain a minimum cost for power

The background of information on graphite is extensive. A detailed report on graphite technology and

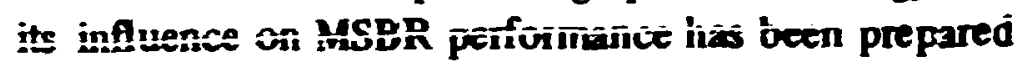
by Kasten et al ${ }^{12}$ A few factors are briefly reviewed here.

Grade $\mathrm{CGB}^{13}$ was the first graphite designed specifically for moltensalt reactor use and was first made in commercial quantities for the MSRE. It is basically a petroleum needle coke bonded with coal-tar pitch, extruded to rough shape, and graphitized at $2800^{\circ} \mathrm{C}$ $\left(5072^{\circ} \mathrm{F}\right)$. High density and low gas permeability were achieved through multiple pitch impregnatiors and heat treatments. The material is highly anisotropic, however, and while suitable for the MSRE neutron fluence, it would not have the dimensional stability needed for an MSBR. ${ }^{14}$

\footnotetext{
13 P. R. Kasten et d., Graphite Behavior and Its Effects on MSBR Peformance, ORNL-TM-21 36 (December 1968).

${ }^{13}$ A product of the Carbon Products Division of Union Carbide Corp.

${ }^{14}$ See ref. 10 for other properties of MSRE graphite.
}

Tests of the graphite indicate that isotropy is essential if linear dimensional changes and overali volume chariges are to be kept small in irradinted material. A graphite with strong binder and a fainiy high density also appears to be important. For tiss reason, isotropic graphite has been specified for use in the MSBR concepts. Unless otherwise noted, this is the type of graphite implied throughout this repurt. The nomind physical properties expected of the graphite before irradiation are giver1 in Table 3.5 .

There has been recent progress in the development of isotropic and nearisotropic gredes of graphite having greater resistance to dimencinnal changes under irsdietion. Some of the sources of materials are Speer Carbon Company (grades 9948, 9949, 9950, 9972), Poco Graphite, Inc. (grades AXF, AXF-5Q, etc.), Carbon Products Division of Union Carbide Corforation (grades AT J.S and ATJ-SG), and Great Lakes Carbon Compeny (grades H31 SA and H537). The isutropic graphites con be made into various shapes by means of conventional molding equipment, the limits on the gs permeability playing a major role in the sequences of operntions. Much of the manufacturing information. however, is proprietory and unpubliched.

While different grades of graphite betore somewhat differently, it can be generally said that single gaphite crystals expand in the cexis direction and contract in the a-axis direction under irradiation by highenergy neutrons. When large numbers of crystals are bonded together to form a piece cf comnercinl graphite, the behavior under irradintion tends to be that hown in

Table 3.5. Nowinal Vates for Properties of Grephite

\begin{tabular}{|c|c|}
\hline 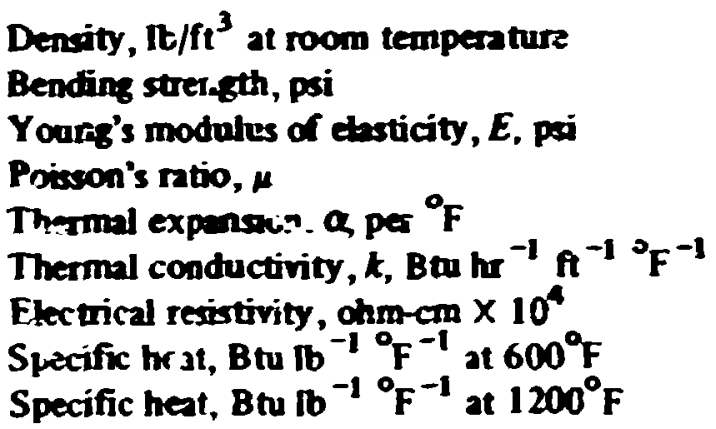 & $\begin{array}{l}-115 \\
4000-6000 \\
1.7 \times 10^{6 b} \\
0.27^{c} \\
2.3 \times 10^{-6 d} \\
22-41^{e} \\
8.9-9.9 \\
0.33 \\
0.42^{f}\end{array}$ \\
\hline
\end{tabular}

A specific grade of graphite and supptier had not been selected for the two-fluid MSaR. Many of the graphite properties were, and still are, under investigation.

$b_{E}=E_{0}+1.2 \times 10^{2} T$, where $E=$ Young's modalus, pai, $E_{0}=$ n.odulus at room temperature of $70^{\circ} \mathrm{F}, T={ }^{\circ} \mathrm{F}$.

CPoiston's ratio is temperature independent.

$d_{\alpha}=3.83 \times 10^{-6}+8.26 \times 10^{-9} T-1.00 \times 10^{-11} T^{2}$, where $T={ }^{\circ} \mathrm{C}$ between 490 and $1000^{\circ} \mathrm{C}$

$e_{k}=3.3 \times 10^{3} T^{0.7}$, where $T={ }^{\circ} \mathrm{R}$ between 550 and $4500^{\circ} \mathrm{R}$, $k=B t u h \mathrm{hr}^{-1} \mathrm{ft}^{-1}{ }^{\circ} \mathrm{F}^{-1}$.

$f_{\text {Ref. } 10 .}$ 
Fig. 6.4. Initinlly the volume contracts and the density increases as some of the imperfections in the structire are filled. On continued irradiation she volume increases sharply, passing through the initial volume at a fluence that decreases with increasing temperature. After examining the available data we conduded that a fluence of about $2.5 \times 10^{22}$ neutro.as $/ \mathrm{cm}^{2}$ equivalent Pluto dose could be sustained at $600^{\circ} \mathrm{C}\left(1112^{\circ} \mathrm{F}\right)$ without deterioration of the physical properties of the graphite. As explained in Sect. 6, this corresponds to a fluence of $5.1 \times 10^{22}$ neutrons $/ \mathrm{cm}^{2}(E>50 \mathrm{kev})$. For purposes of the design studies reported here, the time to accumulate this dose was taken as the design lifetime for the graphite in the reactor core. ${ }^{15}$

Graphite with a density of $115 \mathrm{lb} / \mathrm{ft}^{3}$ contains about $23 \mathrm{wol} \%$ wids. Low permeation of salt into the voids is desirable to keep both the fission product poisoning and the internal hat generation low, particularly after the reactor is drained. For the MSKE design we specified that less than $0.5 \%$ of the bulk volume of the gaphite should will with salt; specimens of grade CGB gaphite averaged less than $0.2 \%$. The fued and blanket silts do not wet the graphite sifface, ${ }^{12}$ and a pore size of less than about $1 \mu$ is suffi:ient to effectively keep the salt out of the material. Experience with the MSRE indicates that irradiation does rot change this characterintic.

Geseous fiscion products tend to diffuse from the salt into the voids in the graphite. The graphite should have a low ges permeabitity to reduse the levels of the xenon poison in the core and also to keep the heat generation due to decay of fission product gases within the graphite low. A target value of $0.5 \%$ xenon poison fraction was selected for the two-fluid MSBR. The permeability of graphite is usually measured with helium at roum temperature, and a value of less than $10^{-7} \mathrm{~cm}^{2} / \mathrm{sec}$ is necessary if the diffusion of xenon at reactor temperature is to be kept to an acreptable level. Recent tests of six grades of isotropic graphite which are of interest in the MSBR prozram showed permeabilities ranging from $3 \times 13^{-4}$ to $1 \times 10^{-2}$ $\mathrm{cm}^{2} / \mathrm{sec}^{16}$ Reducing the permeability sufficiendy by

\footnotetext{
15 In subsequent studies of onofluid reactors the design Setime was limited to a fuence of $3 \times 10^{22}$ neutons $/ \mathrm{cm}^{2}(E$ $>\mathrm{SO} \mathrm{kev}$ ) on the basis that expension of the grohite much heyond the initial volume might increase the permeability to alt and to accoint for the more rapis changes that oc is at the hicher temperatures of 700 to $720^{\circ} \mathrm{C}$ in the graphite. More resent dato (July 1969) seem to confirm that the lower flience is a inetter value for graphite obtainable in the near future.

${ }^{16}$ MSR Program Semiann Propr. Rept. Feb. 28, 1969, ORNL4396 (A1G. 1969).
}

pitch impregnation and graphitization tre?tments would be very difficult; however, it is pusible to achieve acceptable permeabilities by depositing pyrolytic carbon in the surface pores.

In sealing the graphite with pyrolytic carbon the radiation-induced dimensional changes in the two materials may be sufficiently different to cause spalling of the coating. This problem can be largely circumventeci, however, if the carbon is deposited in pores near the surface rather than on the surface itself.9 A method fcr depositing the pyrocarbon has been developed at ORNI. The graphite is oyded betriecn a vaciuimi ând a regulated pressure of hydrocarbon (butadiene) gas while it is being heated in a high-frequency induction field to between 800 and $1000^{\circ} \mathrm{C}\left(1472-1832^{\circ} \mathrm{F}\right)$. The cycles are of a few seconds duration, and permeabilities of less than $13 \times 10^{-10} \mathrm{~cm}^{2} / \mathrm{sec}$ have been obtained.' 'In one series of tests the depth of penetration at $800^{\circ} \mathrm{C}$ $\left(1472^{\circ} \mathrm{F}\right)$ sealing temperature was found to be about 0.015 in.

Calculations were made by Kedl' to determine the effect on the xenon poison fraction of sealing the graphite with a thin layer of pyrolytic carbon (or other l.ow-permeability graphite). Various xenon parameters were chosen that would yield a high ${ }^{135} \mathrm{Xe}$ poison fraction with ordinary graphite, and the calculations were then extended to demonstrate the effect of the coatings. The void fraction available to xenon was made variable in such a way that it changed by one order of magnitude when the diffusion coefficient changed by two orders of magnitude. The diffusion coefficient of $10^{-3} \mathrm{ft}^{2} / \mathrm{hr}^{18}$ assumed for the bulk graphite is believed to be readily attainable. The results are presented in Fig. 3.4. It is interesting to note that the diffusion coefficient in the bulk graphite would have to be $10^{-7}$ $\mathrm{ft}^{2} / \mathrm{hr}$ or less in order to obtain a significant reduction: in the xenon poison fraction, whereas an 8-mil coating of $10^{-8} \mathrm{ft}^{2} \mathrm{hr}$ material would reduce the poison fraction to the target value of $0.5 \%$.

\subsection{Graphite-to-Metal Joints}

The two-fluid MSBR concept involves the joining of the graphite core elemerits to stubs of Hastelloy $N$ tubing which are then welded into the tube sheets, as indicated in Figs. 5.3 and 5.5. The graphite-to-metal

\footnotetext{
17 MSR Program Scmiann Progr. Rept. Aug 31, i968, ORNL -4344 (Feb. 19ú9).

${ }^{18}$ The diffusion coefficients given in $\mathrm{F}$ ig. 3.4 are in $\mathrm{ft}^{2} / \mathrm{hr}$ for xenon at $1200^{\circ} \mathrm{F}$. These are numerically about equal to the room temperature diffusion coefficient for helium given in $\mathrm{cm}^{2} / \mathrm{sec}$.
} 


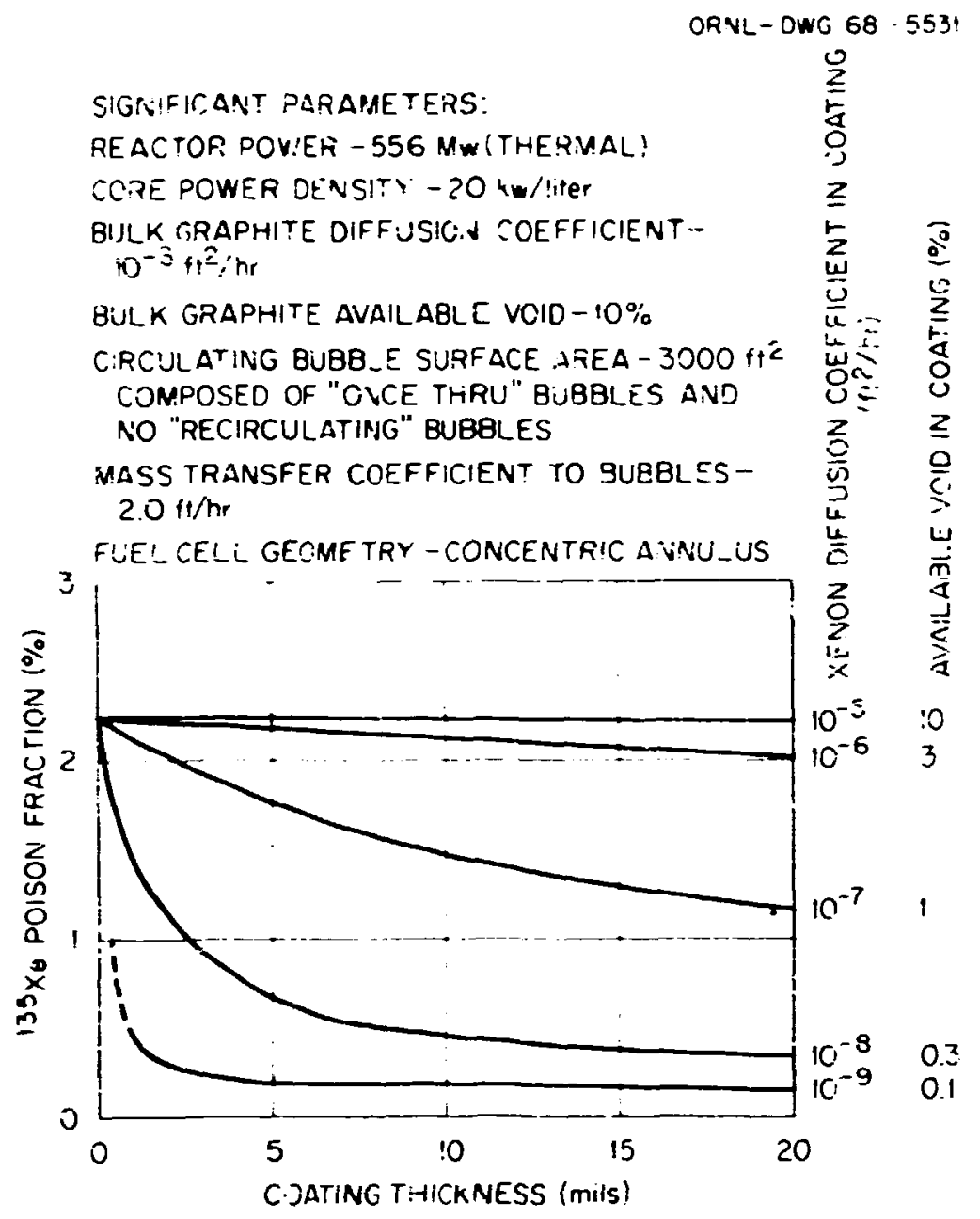

Fig 3.4. Effect of Pyrolytic Carbon Coating for Graphite on Xemon Poison Fraction in Two-Fluid MSBR.

joints would be made under carefully controlled shop conditions. Methods for joining the graphite and Hastelloy are being studied at ORNL and have progressed sufficientiy to indicate that the materials can be successfully brazed together.

It is difficult to join graphite directly to Hastelloy because the thermal coefficient of expansion of the graphite is significantly lower than that of the metal. The mean coefficient of thermal expansion of isotropic graphite in the temperatuie range between 70 and $1100^{\circ} \mathrm{F}$ is about $2.4 \times 10^{-5}$ in. $/{ }^{\circ} \mathrm{F}$, whereas that of Hastelloy $\mathrm{N}$ is about $6.8 \times 10^{-6}$ in. $f^{\circ} \mathrm{F} .{ }^{9}$ This difference is of primary concem when cooling from brazing temperatures of about $2300^{\circ} \mathrm{F}$.

One of the approaches to the problem is to design the joint so that the Hastelloy $\mathbf{N}$ applies a compressive load on the graphite as it cools, the graphite being stronger in compression than in tension. Another approach is to join the graphite to a transition material having a coefficient of thermal expansion more nearly that of the graphite. This material would in tum be brazed to the Hastelloy $N$. ' refinement of this is to use a series of transition materials that would approach the thermal expansion properties of the Hastelloy $\mathrm{N}$ in steps.
One of the families of naterials investigated for use in transition pieces is the heavy-metal alloys of tungsten or molybdenum. It was found that tungsten with nicket and iron added in the ratio $7 \mathrm{Ni} / 3 \mathrm{Fe}$ gave far better iabrication characteristics than those with inolybdenum. ${ }^{17}$ By adjusting the composition, the thermal crefficient of expansion can be varied over the requisite range of about $3 \times 10^{-6}$ in $f^{\circ} \mathrm{F}$ to $6 \times 10^{-6}$ in $f^{\circ} \mathrm{F}$ as shown in Fig. 3.5. ${ }^{17}$ Segments with highest tungsten concentration would be located adjacent to the graphite, and the segments with the most nickei and iron would be next to the Hastelloy.'

Test specimens were prepared using nuclear-grade graphite as weil as the Poco type, which has a higher coefficient of expansion, as shown in Fig. 3.5. The distribution of the expansion coeficicients of the individual segments in relation to those for the graphite and the Hastelloy $\mathrm{N}$ is also shown in Fig. 3.5. The compoites were made by fabricating the segments individually and copper-brazing them together in a vacuum under light load. To achieve an effective bond between the graphite and the metal requires prior metallizing of the graphite suriace by subjecting it to gaseous products of a graphite $-\mathrm{Cr}_{2} \mathrm{O}_{3}$ reduction reaction conducted under a low vacuum at $1400^{\circ} \mathrm{C} .^{17}$

A minimum of intervening segments was employed in an attempt to reduce fabrication costs. A typical specimen consists of nuclear graphite, a 0.2 in.thick segment of Poco graphite, a 0.2 in.thick segment of $80 \% \mathrm{~W}-14 \% \mathrm{Ni}-6 \% \mathrm{Fe}$ alloy, and a 0.2 in.thick segment of $60 \% \mathrm{~W}-28 \% \mathrm{Ni}-12 \% \mathrm{Fe}$ alloy joined to the

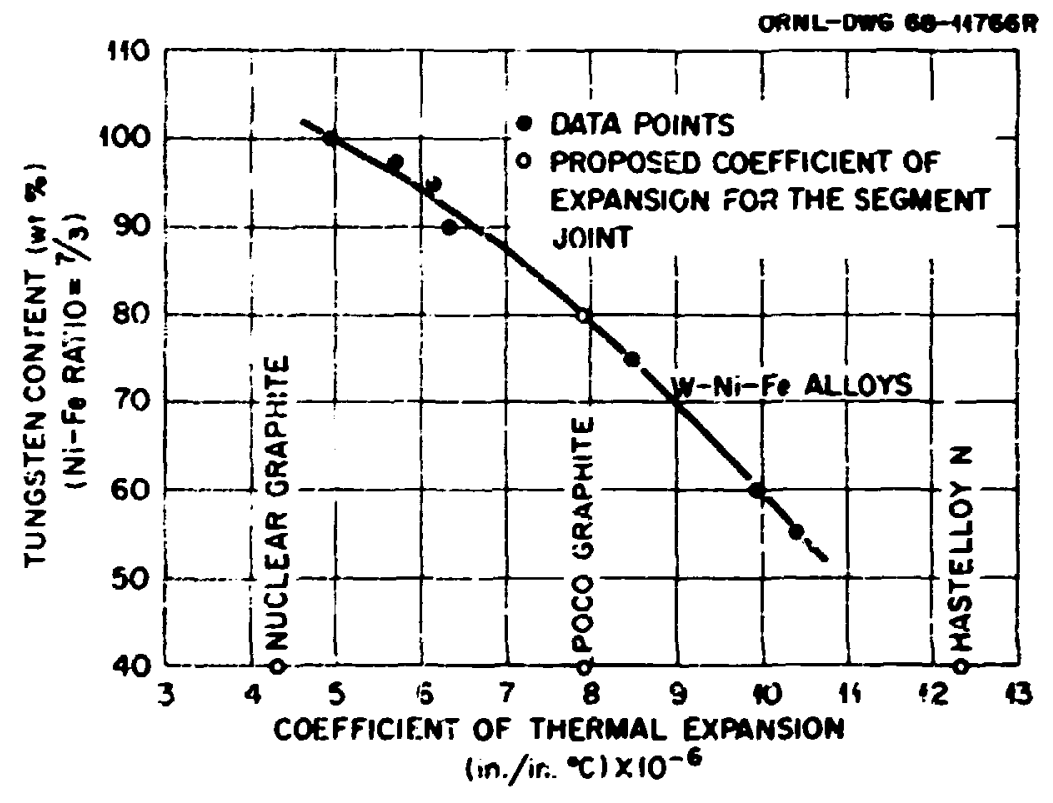

Fig 3.5. Fxpansion Coefricients of Trandition Joint Material. as a Function of Composition. Coefficients are mean values between room temperature and $600^{\circ} \mathrm{C}$ and were determined on an optic al interferometer. 
Hastelloy N.1; Extensive temperature cycling of the specimens between $750^{\circ} \mathrm{C}$ and roum temperature over a 20 -min cycle failed to produce detectabie cracks. The copper bond between the metallized graphite and the tungsten alloy remained intact, and there was no evident reaction or alioying of the copper with the chromium carbide. It was concluded that the graphiteto-metal joint would give good performance under MSBR service conditions. ${ }^{16}$

\section{GrivERAL PLANT DESCRIPTION AND FLOWSHEETS}

\subsection{General}

A large MSBR power station consists of three main sections: the reactor plant that furnishes hightemperat ure steam and breeds new fissionable material, the turbine that generates tise electric power, and the chemical plant that processes the saits. The functions and equipiment for the three plants are closely interdependent, but it is convenient to disciss them separately. Less emphi is will be given to the descriptic of the turbine plant, since this involves more or less standard equipment.

In the 100,-3 Mw(e) power station described in this report, the hat is generated in four reactors, each designed for a thermal output of about $575 \mathrm{Mw}(\mathrm{t})$. Each reactor module is distinctly separate from the others, having its own reactor vessel, primary fuel and blanket neat exchangers, sait-circulating pumps, steam generators, and stern reheaters. One chemical processing plant serves ail four reartur mociuls. The steam provided by the four modules supplies one 1000-Mw(e) turbinegenerat or in the turbine plaint. One regenerative feedwater system consisting of two parallel streams returns boiler water io the reactor modues.

The reactor plant was the ma $\mathrm{n}$ subject of these design studies, and very little was done on the site and tuilding layouts and on the chemical processing in addition to what was reported in ORNL-3996.' In the interest of making this report more complete, we have included some information from ORNL-3996.

\subsection{Siie}

The plant site is that described in the AEC handbook for estimating costs. It is a 1200 -acre plot of grasscovered, level ieriain adjacent to a river having adequate flow for cooling-water requirements. The ground elevation is $20 \mathrm{ft}$ above the high-water mark and is $40 \mathrm{ft}$ above the low-watei level. A limestone foundation exists about $8 \mathrm{ft}$ below grade. The location is satisfactory with respect to distance from population centers, meteorological conditions, frequency and intensity of earthquakes, and other environmental conditions.

As shown in Fig. 4.1, the plant is in a 20-acre fenced area above the high-water contour on the bank of the river. The usual cooling-water intake and discharge structures are provided, along with fuel-oil storage for a

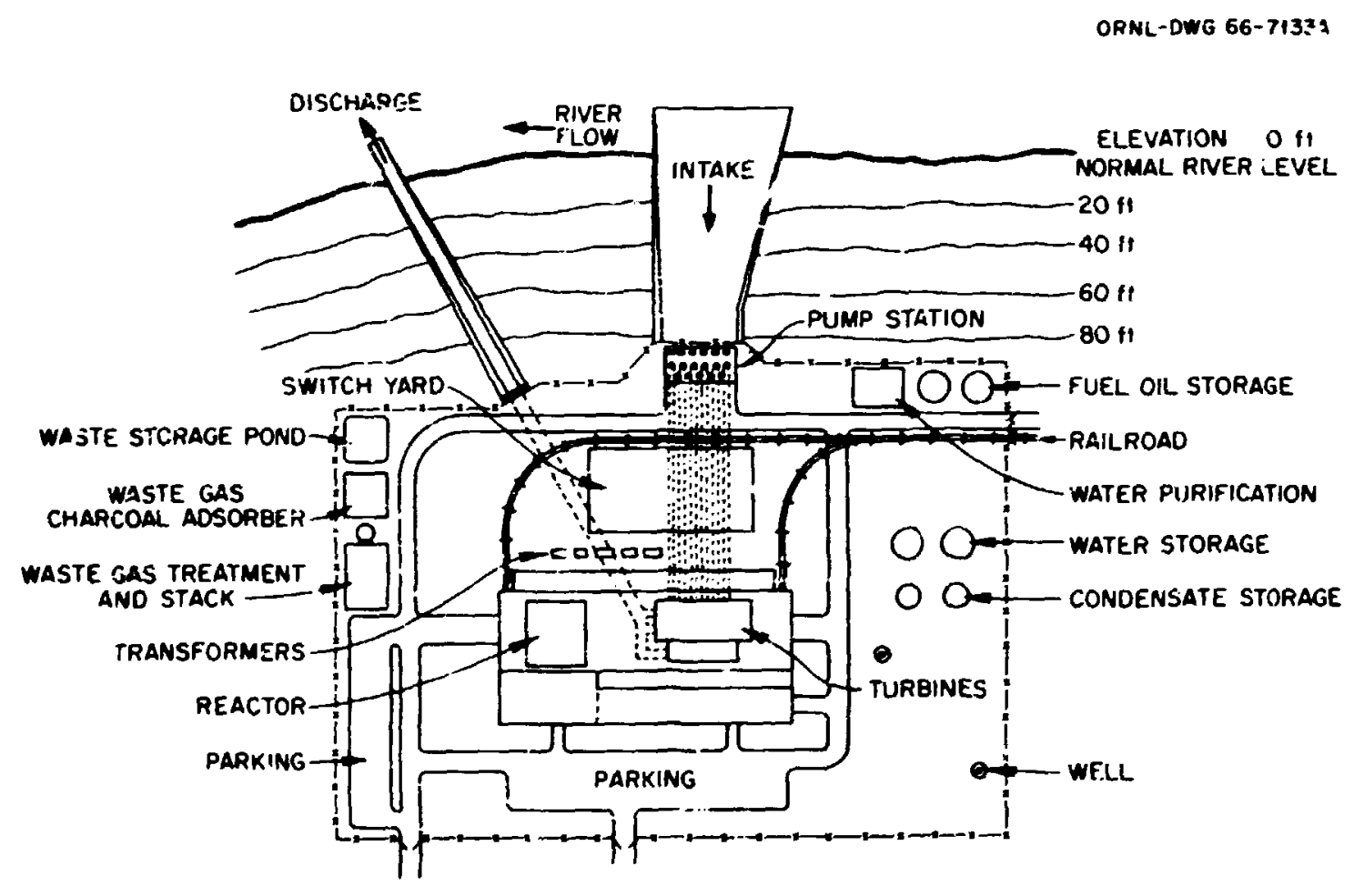

Fig 4.1. Plant Site Layout. 
startup boiler, a water purification plant, water storage tanks, and a deep well. This plant area also inclutes systems for treatment, storage, and disposal of radioactive wastes. Spuce is provided for transformers and switchyard. A railroad spur serves for transportation of heavy equipment.
One large building houses the reactor, chemical processing, and turbine plants, offices, shops, and all supporting facilities. One version of this building, shown in Figs. 4.2 and 4.3, is $250 \mathrm{ft}$ wide and $530 \mathrm{ft}$ long; it rises 98 it above and descends 48 :t below grade level. An alternative plan in which the building is $340 \mathrm{ft}$

ORNL-DWG 66-7138A

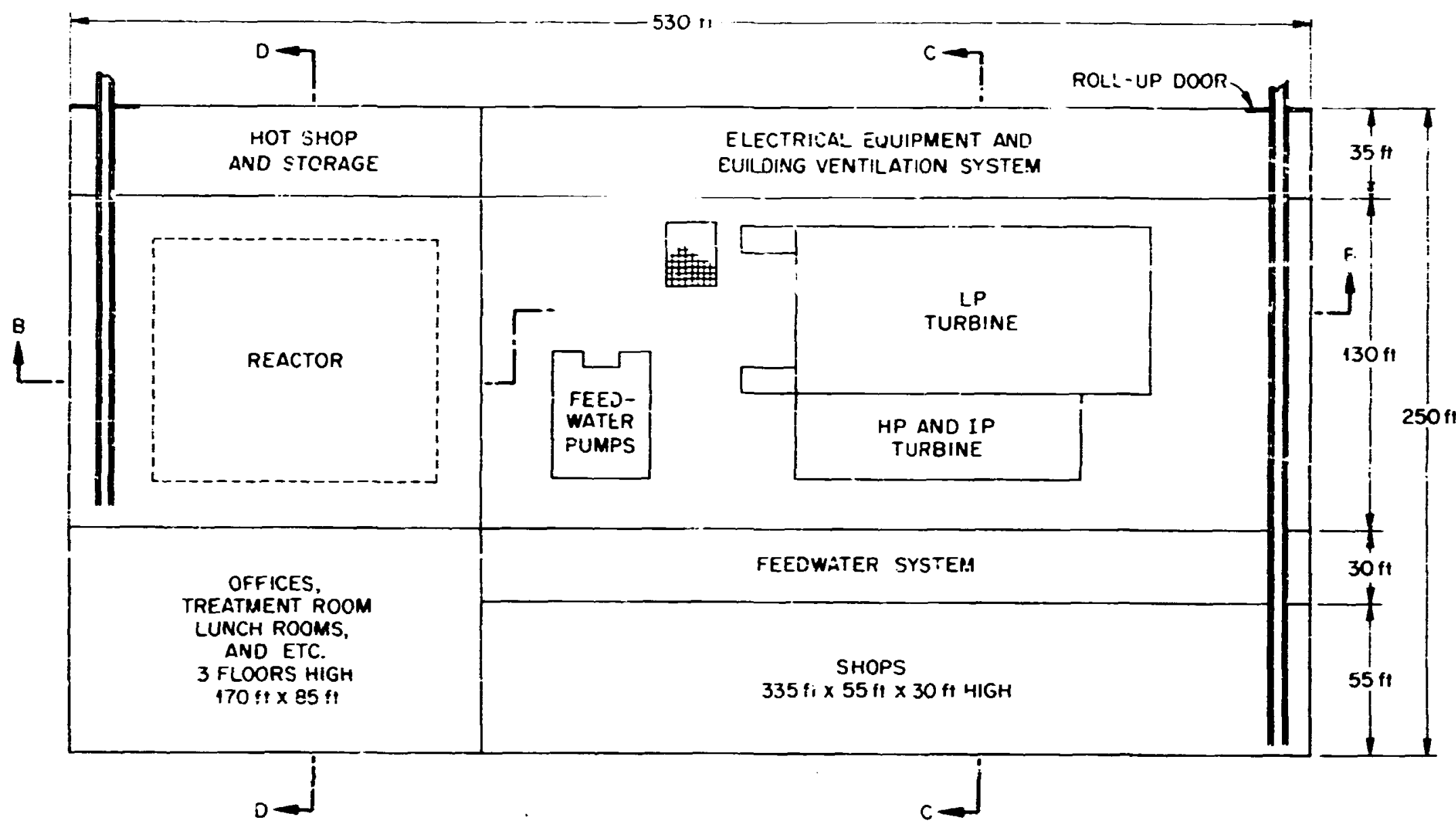

Fig. 4.2. Building Plan.

ORFLL-DWS 66-7137A

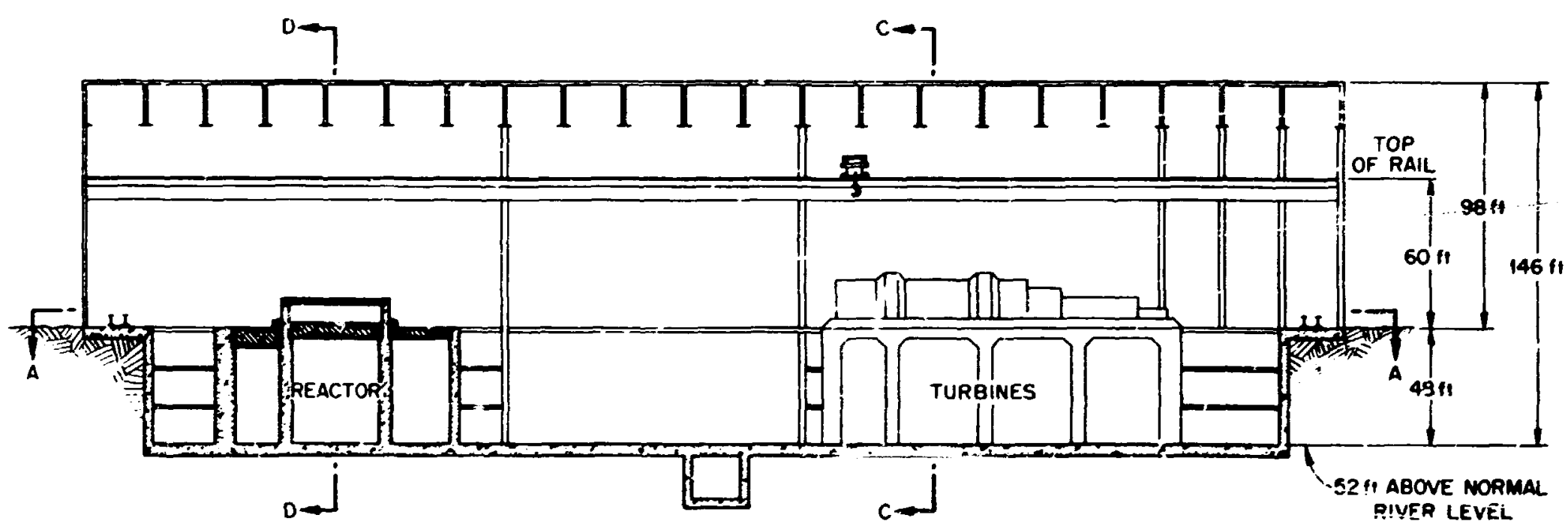

Fig. 4.3. Building Elevation. 
ORNL-OWG 7O-2:74

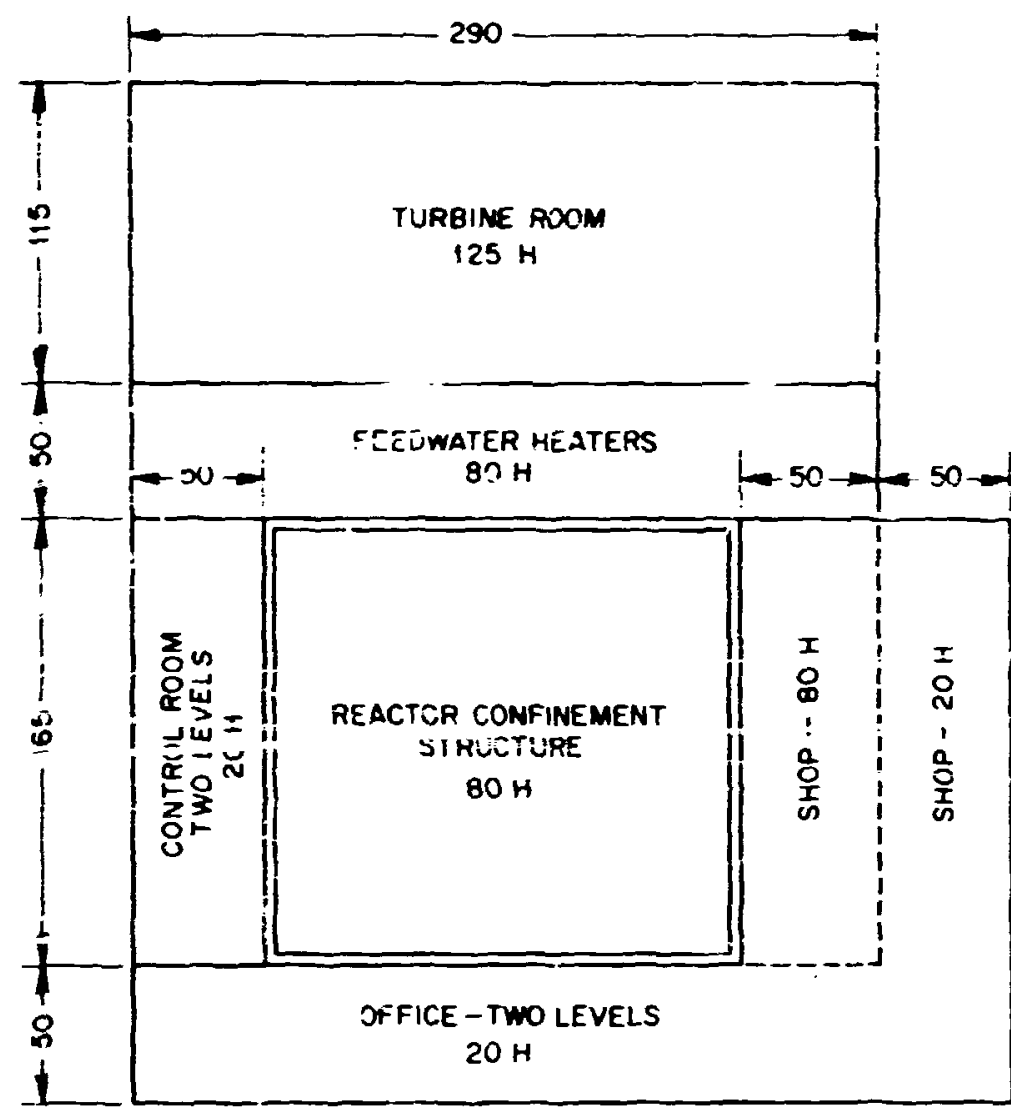

NOTE: DIMENSIONS IN FEET

Fig. 4.4. Alternative Building Layout (Used in Cost Estimate).

by $380 \mathrm{ft}$, a s shown in Fig. 4.4, was used in estimating the building costs. In either case, the building is of steel frame construction with steel roof trusses, precast concrete roof slabs, concrete floors with steel grat:ngs as required, and insulated aluminum or steel panel walls. The wiji joints are sealed in the reactor end of the building io provide a confinement volume in the event of a release of radioactivity. The reactor area is provided with a separate ventilation and air-filtration system that discharges to a stack.

\subsection{Reactor Plant}

\subsubsection{Flowshest}

A flowsheet ior a reactor module is shown in Fig. 4.5. In brief, the fitel salt enters the botiom of the reactor ressel at a rate of $25 \mathrm{cfs}$ at $1000^{\circ} \mathrm{F}$, passes through the core, and leaves at about $1300^{\circ} \mathrm{F}$. It then enters the fuel salt pump at the top of the primary heat exchanger, where it is pumped into the center section of tubes. After revening direction at the bottom, the salt flows upward through the outer section of tubes and inio inic return lins : $o$ the bot:om of the reactor.
The fuel zalt pump anu its sump, or pump tank, are below the reactor vessel, so that failure of the pump to develop the required head causes the salt to drain from the reavior vessel through the pump tank to the fuel salt drain tank. The tank above the pump impeiler is required during startup so that she fuei salt can he pressurized frem tite dira:s tainh into the primary system to provide the purnp with the necessary subinergence and surge volume as it starts and fills the reactor core.

Helium is used as ithe cover gas oyer the salt in the pump bout and as the medium for stripping greous fission products from the salt. For this latter nurpiuse, snall bubbles are injected ints the salt in the suction line to the pump and are removed with their burden of krypton and xenon in a centrifugal separaior in the line from the outlet of the heat exchanger to the reactor vessel. This gas is rirculated tirrough a gaseous fission product disposal system, described in Sect. 5.9.

The blanket salt enters the reacter vessel at a rate of $4.3 \mathrm{cfs}$ at $1150^{\circ} \mathrm{F}$. It flows along the vessel wall, through the interstitial spaces between the graphiite elements of the core and the radial blanket, an 1 exits at about $1250^{\circ} \mathrm{F}$. The fertile salt then flows into the suction of the blanket pump and is pumped through the blanket heat exchanger and back to the reactor vessel. Helium covers the blanket salt at the salt-to-gas interface in the pump. Only a small fraction of the fissions occurs in the blanket, so there is no need for a gaseors fission product removal system.

The sodium fluoroborate coolant sait is circulated to the bottom of the fuel salt heat exchanger at a rate of $37.5 \mathrm{cfs}$ at $850^{\circ} \mathrm{F}$, flows upward through the shell, and leaves at about $1111^{\circ} \mathrm{F}$. It then flows through the shell of the blanket salt heat exchanger, where it is heated to about $1125^{\circ} \mathrm{F}$, and returns to the coolant salt circulating pumn, where its pressure is ia ind from about 110 psig to 260 psig. The plimp supplies about $87 \%$ of the cuolant salt to the steam generators and the remainder to the steam reheaters. A cover-gas system is required for the coolant arcuit, the cover gas being a mixture of boron trifluoride in helium. There is no requirement for injecting cover gas into the circulating salt or for removing it.

Each of the salt circulating systems is provided with heated drain tanks for safe storage of the salt during shutdown of the reactor. These ianks are described in detail in Sect. 5.6. The fuel drain tanks have conling systems for removal of afterheat. Flo'w of salt to the tanks during a drain is oy gravity; salt is retumed to the systems from the tanks by pressurizing the tanke with. inciivin. A sait seal is frozen in the special valves in the drain lines to effect a positive cuitaff. 


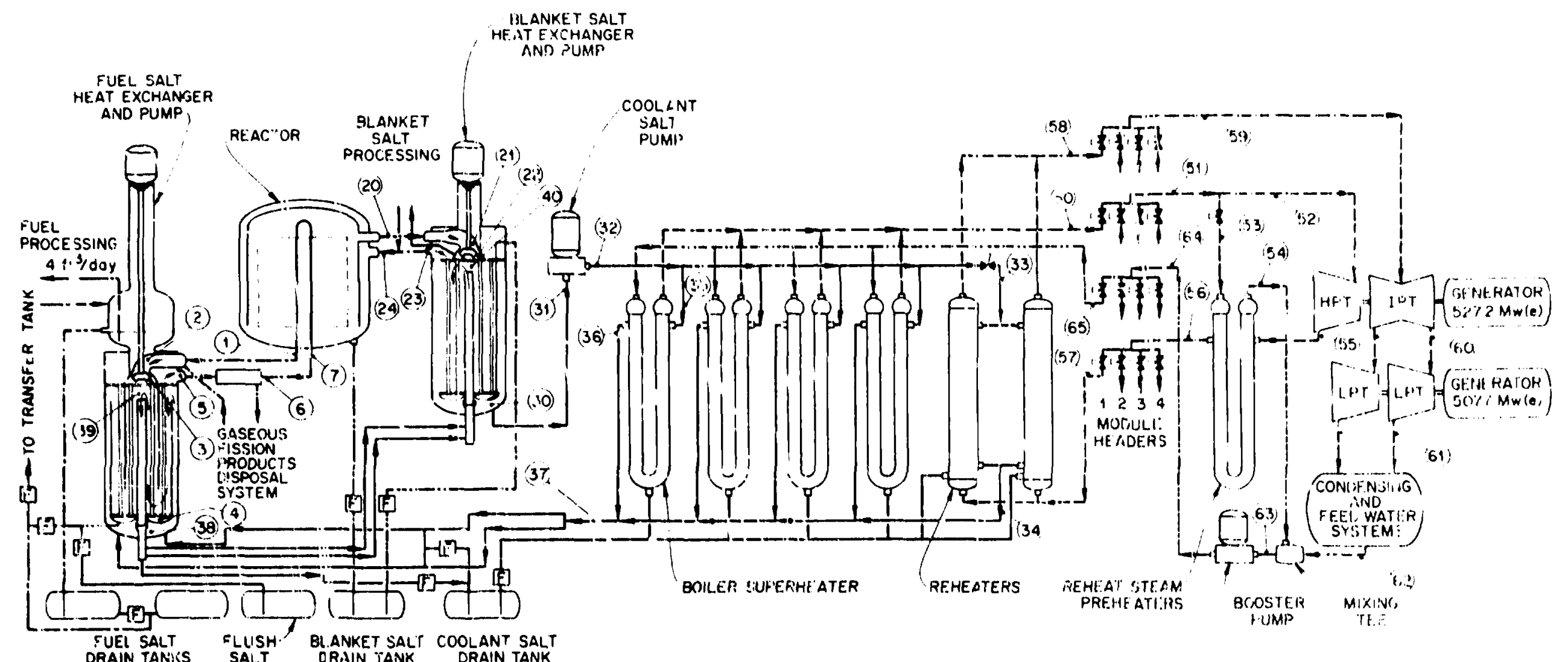

$$
\text { FUEL }
$$

POINT $11^{3 / 20 C}$ PSIO TEMP ("F)

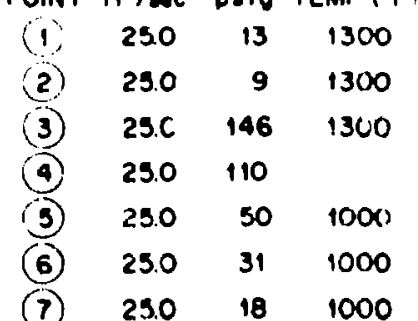

(7) $250 \quad 18 \quad 1000$

\begin{tabular}{|c|c|c|c|}
\hline \multicolumn{4}{|c|}{ BLANKET } \\
\hline 29 & 13 & 125 & $1 ? 30$ \\
\hline & 4.3 & $6 . c$ & 1250 \\
\hline 2 & 43 & 1110 & 1250 \\
\hline & 4.3 & 20.0 & 1150 \\
\hline & $4.3 i$ & 14.5 & 1150 \\
\hline
\end{tabular}

COOLANT POint $133 /$ soc pasig TEMP (०F) (3) $37.5 \quad 129 \quad 1125$ (31) $37.5 \quad 110 \quad 11.35$

(32) $37.5 \quad 260 \quad 11: 5$ (33) $50 \quad 20 \mathrm{OB} \quad 1125$ (34) $3.0 \quad 212 \quad 850$ (35) $8.1 \quad 252 \quad 1125$ (36) $\quad 8.1 \quad 194 \quad 850$ (37) $37.5 \quad 203 \quad 850$ (38) $37.5 \quad 198 \quad 850$ (39) $37.5 \quad 164 \quad 111$

(40) $37.5 \quad 138$
STEAM

POINT 10" Ib/hr Fsio TEMF' ( $\mathrm{F}$ ) (30) $2.52 \quad 3600 \quad 1000$ 31) $1007 \quad 3600 \quad 1000$

(52) $7.15 \quad 3131 \% \quad 100 \mathrm{C}$

3ii) $\quad 2.92 \quad 3515 \quad 1000$

134. $\quad 2.92 \quad 3500 \quad 866$

(i5) $5.13 \quad 500 \quad 552$

(36. $\quad 3.11 \quad 570 \quad 650$

(s) $1.285570 \quad 650$

(58) $\quad 1.28 \quad \$ 40 \quad: 000$

$\begin{array}{llll}(58) & 1.78 & \$ 40 & : 000 \\ (54) & 313 & 340 & 100 n\end{array}$

(60) $\quad 3.00 \quad 172 \quad 706$

(61) $430 \quad 15 \mathrm{inth} \quad 92$

(62) $\quad 7.16 \quad 3500 \quad 551$

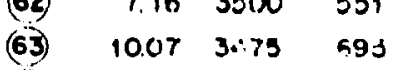

(6) $10.073800 \quad 700$

(68) $2.52 \quad 3800 \quad 700$
DFRIOPMANCI OATA 1,O0) MW'O GENE.FA IOA FI.ANT NET OUTPL'T $1600 \mathrm{NW}$ WEl IFOOSS IF NERAIION $13349 \mathrm{Mm}$ ROILER FEEJ FUMPS $294 \mathrm{M}$ GOOSTER PUMFS $92 \mathrm{Mv}$ STATION A.JXH.LA.RT $257 \mathrm{Mn}$ (E) FEACTCH HEAT IVPIJT 2225 Mve(1) NET HEATI RATE PEOI Blu/kwhr NET EFFICIENCY $149 \%$ HUEL I.E(EN) BLANKET - - ........... COOLANT
STEAM STEAM

WATEE VE VALVT

UATA POINT

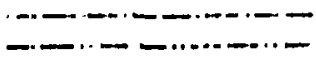
思 
A small side stream of fuel saii : taken frotis the fuel vystem at the circulating puinp discharge. siftei storage in a tarister tank, the siti is processed and reconstituted in the assocalte : temical phant to remove âssion product contaminants and to arijit: the composition. The dien sait is retumed to the circulating system at the pump bust. A side stream is removed from the oianket system, simianly processed for removl of bred ${ }^{2{ }^{3}} \mathrm{~Pa}$ and ${ }^{233} \mathrm{U}$, and returned to the reactor. The flowsheets ir fuei and blanket salt chemical plants are descisined in Sect. 4.4.

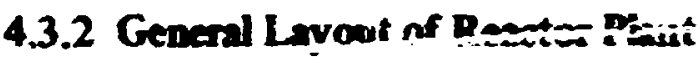

The reactor plant consists of four major cell com. plexes, as sincwn in Figs. 4.6 and 4.7 , ail contained in a reiniorced concrete structure havirg outside dimensions of about 150 by $170 \mathrm{ft}$ and 45 to $65 \mathrm{ft}$ high. Each major cell complex includes a reactor cell, a coolant cell, and a hot-storage ceil to hüuse a spent reactor assembly. Two drain-tank cells and two off-ras cells are located between the main cell complexes, and each servis two reactors. A centrally located insirumentation cell houses equipment for all four reactors. The chemical processing cell and the hot cells needed for maintenance of radioaztive equipment are also integral parts of the structure.

All cells have removable top pligs of reinforced concrete to permit maintenance operations to be peformed from atove by uxe oi remoteiy operated tools and equipment.

ORNL-DWG 68-28A

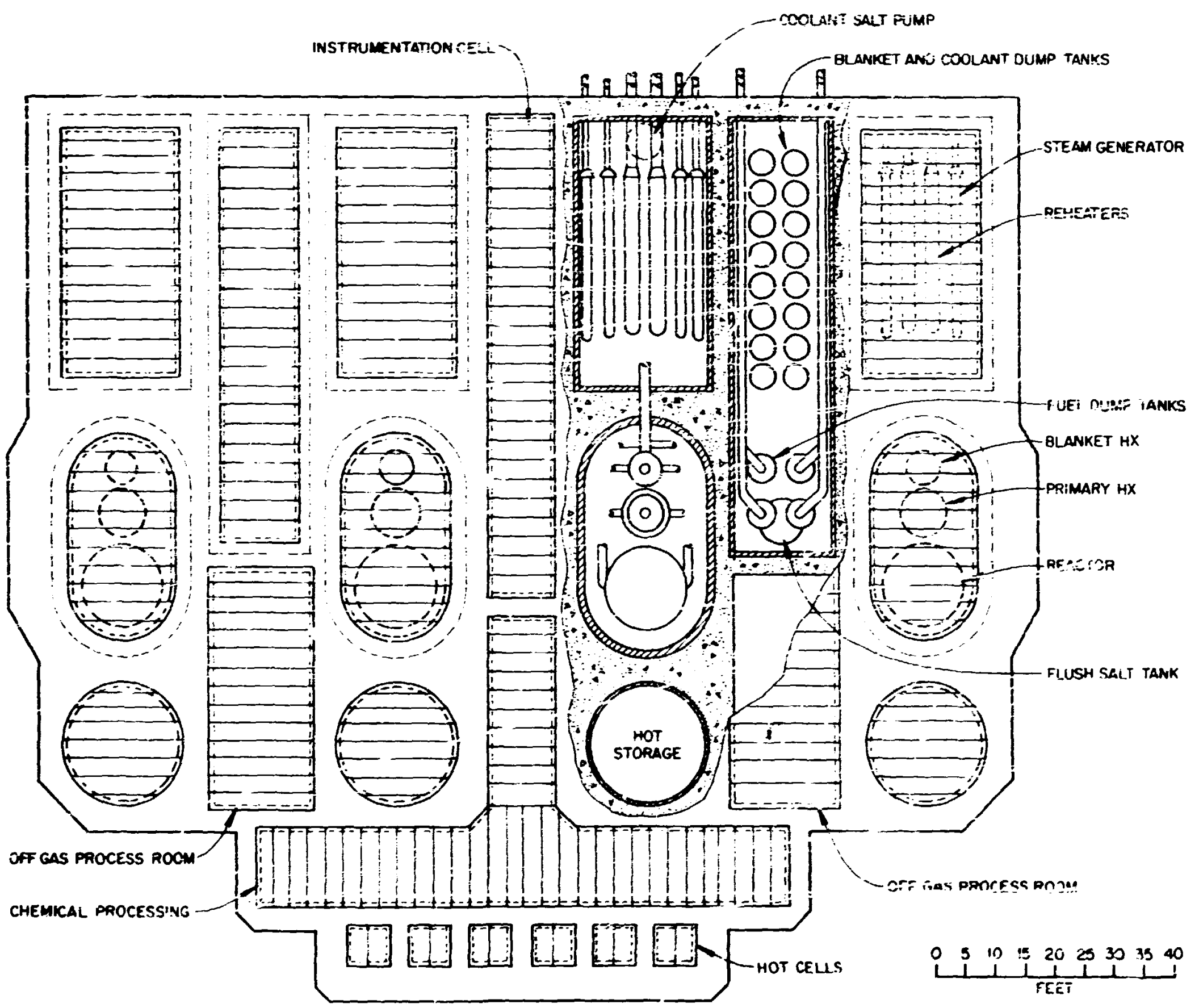

Pig 4.6. Pian View of Reactor Plant. 


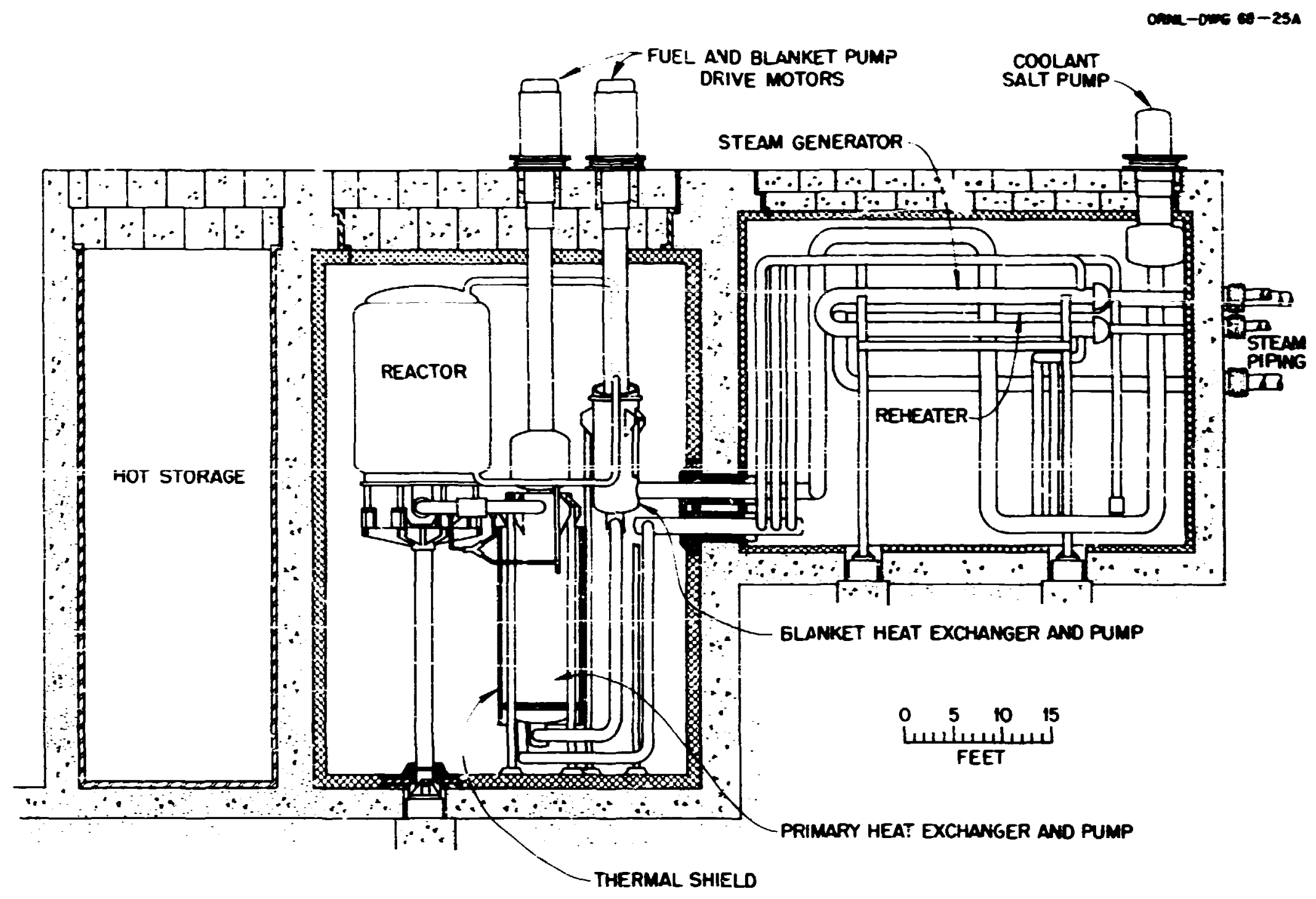

Fig 4.7. Sectional Elevation of Rexctor Cen.

All the cells containing fuel, blanket, and coolant salts are provided with electric resistance heating clements which prebeat the systems and maintain the cell ambient tempersture at about $1100^{\circ} \mathrm{F}$, well above the iiquidus temperatures of the salts. In addition to the massive concrete biological shielding, the reactor cell has thick double-walled steel liners to protect the concrete from excessive temperatures and radiationinduced damage. The liners also seal the cell spaces to provide containment for all equipment which contains radioactive material. The cell structure itself is housed in a sealed confinement building which provides yet another line of deiense against the escipe of fission products.

\subsubsection{Reactor Cell}

As shown in more detail in Fies. 4.7 and 4.8 , the reactor cell contains the $57:-\mathrm{Mur}(\mathrm{t})$ reactor, fuel solt circulating puinip, fuel salt hea: exchanger, blanket salt circu'ating pump, blanket salc heat exchanger, and the interconnecting salt piping. The cell has circular ends of $12 \mathrm{ft}$ radius and is about $24 \mathrm{ft}$ wide by $40 \mathrm{ft}$ long by about $63 \mathrm{ft}$ deep, including the 8-ft thick roof pluzs:

In this design version the major components in the reactor cell are supported on columns, or pedestals, which penetrate the floor of the cell. The columns rest on vibration dampers which are supported on footings beneath ti:e cell floor structure. The degree of protection against seismic disturbances has not been analyzed. (Subsequent design concepts for a single-fluid MSBR adopted an overhead support system.) Differential expansions in the piping and equipment are partially absorbed by the flexibility of the supports. Figure 4.7 shows the single 18 in.diam pedestal for the reactor vessel hinged at the bottom to reduce the stresses in the fuel salt piping. Calculations made on the basis of a fixed joint, however, sve stressen within allowable limits. Because of the high ambient temperature in the reactor cell, the support structure would probably be fabricated of 304 SS. Bellows joints at the base of each column would provide the necesary hermetic seal. 


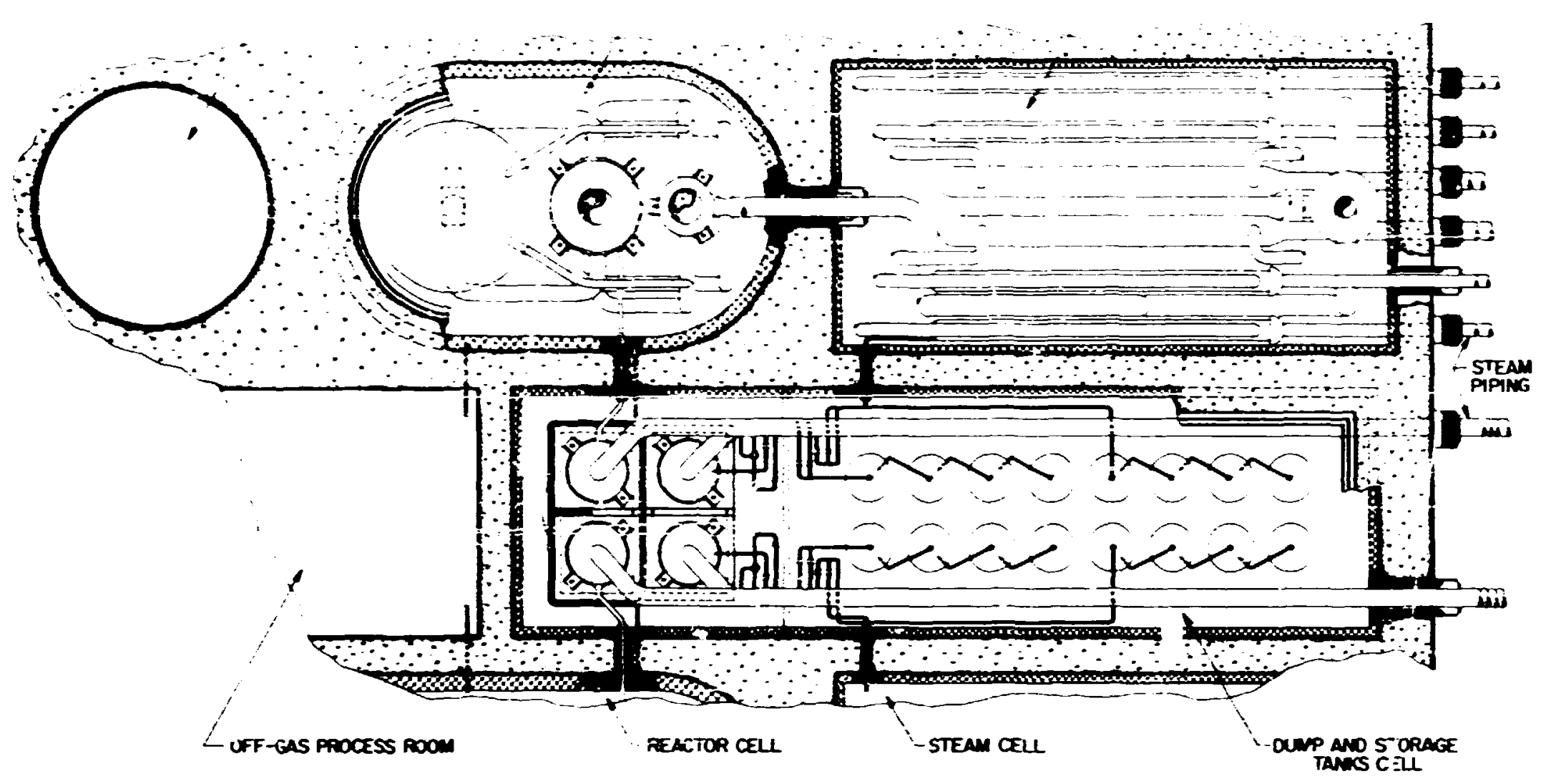

Fig 4.8. Than Virw of Steam Generator and Dria Tank Cells

The reactor cell atmosphere will be an inert gas, probably nitrogen. Since the interior of the cell will operate at about $1100^{\circ} \mathrm{F}$, the cell walls must provide thermal insulation and gamma shielding to prevent ovemeating of the 8. $\mathrm{ft}$ thickness of concrete in the biological shielding. Bbnket-type insulation about 6 in. thick will be used, protected on the inside of the cell by a thin stainless sted lines which will also serve as a radiont heat reflector. The corstruction is shown in Fig4.9. A carbon sted membraite ui the guatide of the thermal insulation provides a sealed structure. The space between this membrane and a surrounding 3 in.thick carbon steel thermal shield is also sealed and continuoudy pumped down and monitored ior leakage through the inner shell. A second 3in. rarbon steel plate is separated from the inner plate by a 3 -in.-wide air space througt. which cooling air is circulated. At an air velocity of about $59 \mathrm{fps}$ the maximum extimated temperat ure of the concrete is less than $200^{\circ} \mathrm{F} .{ }^{19}$

The electric heaters for the cells are Inconel pipes

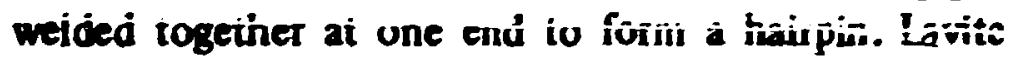

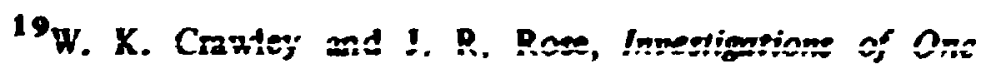
Concept of a Thermol Shiald for the Room Housing a Molien-Salt Breeder Reactor, ORivi-iM-2029 November 1967 .
}

washers separate and support the pipes in the thimbles in which each vait is inserted. These thimbles are irstalled in the pernment portions of the cell roof structure. With this arrangement individual heaters can be disconnected and removed in event of failure. Heaters of this type have proved reliable as reactor vessel heaters in the MSRE.

The reactor cell roof plugs would incorporate the same general design features as the walls. Figure 4.10 shows the double barrier at the top of the reactor cell, at the thimbies for the electric heateri, and also indicates how the cooling air can be introduxed into the removable roof pluss. Figure 4.9 shows how the double barrier sealing membranes would be arranged at the bolion corners of the reactor cell and at the pedestal supports to permit ielative movement. The total heat los frum the reactor cell has been estimated to ive about $2 \mathrm{Mv}(\mathrm{t})$.

The design pressure for the reactor cell is about 50 psia. In considering the integrity of the cell it sriould be noted thai no waier is ioun nitlly preseñi which could accidentaiiy nitix sutith the hot fuel or blanket salt to cause a pressure buidup through reorization. To prevent accidental entry of steam into the cell via the collant sal: circuit, rupture disks are provided on the 

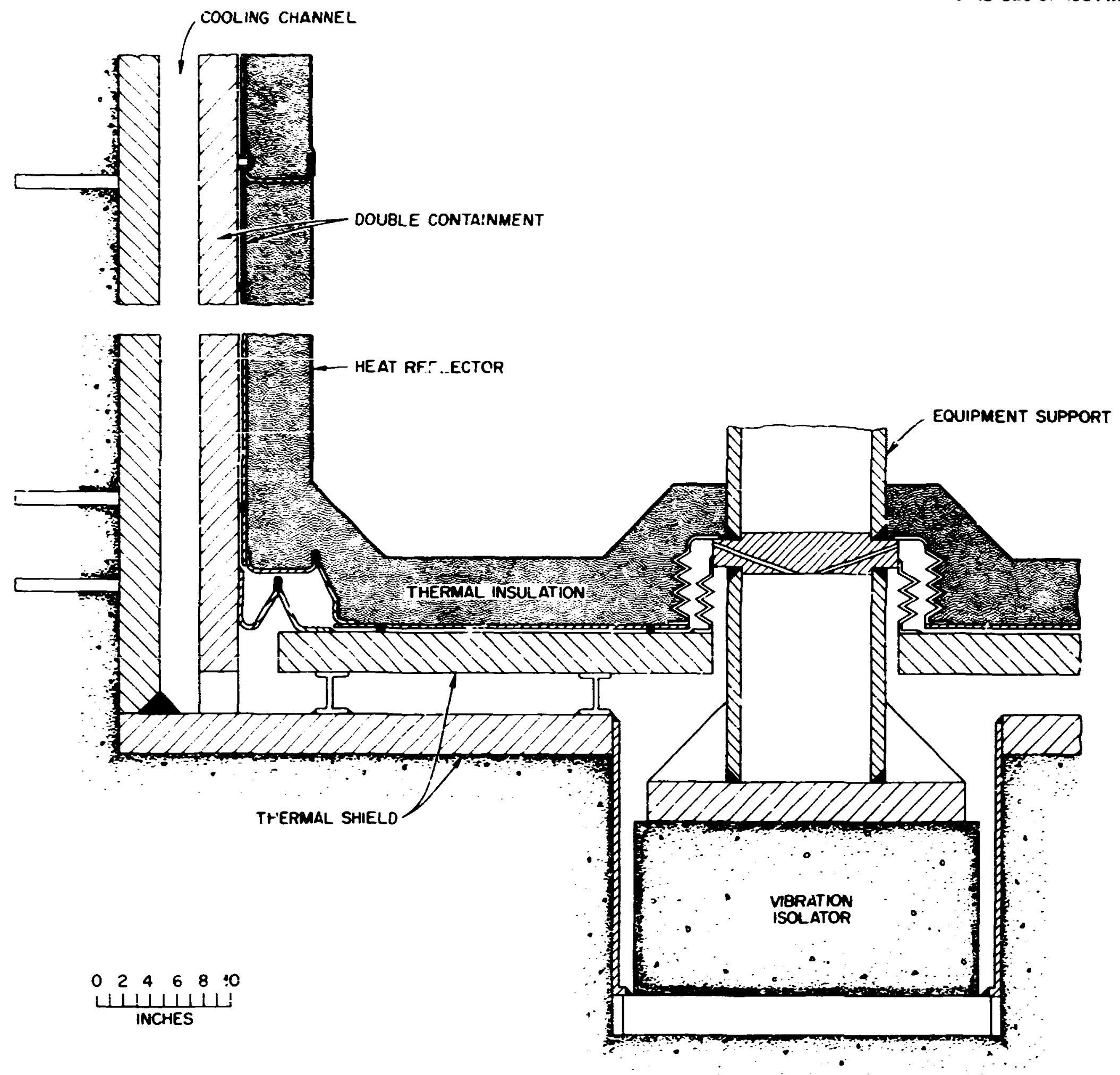

Fig 4.9. Cel Wall Construction at Supports.

secondary systern which would discharge the coolant salt into the steam gerierator cel! if there were a preserre buildup in the system due to a tube failure in the stean generator. The rupture disk ratings would be well below the collapsing pressure of the tubing in the primary heat exchanger, but even in the highly urilikely t:ent of tube collapse and shell rupture, sufficient escape of vapor to cause a significant rise in the reactor cell pressure does not necessarily follow.

\subsubsection{Coobnt Cell}

Each of these four cells contains a coolant salt circulating pump, four boilersuperheater units, trov reheater units, and associated salt and steam piping. The cells are approximately 24 by $45 \mathrm{ft}$ and about $34 \mathrm{ft}$ deep, including the roof plugs.

The construction is similar to that used in the reactor cells in that the cells must be hieated and sealed. The 


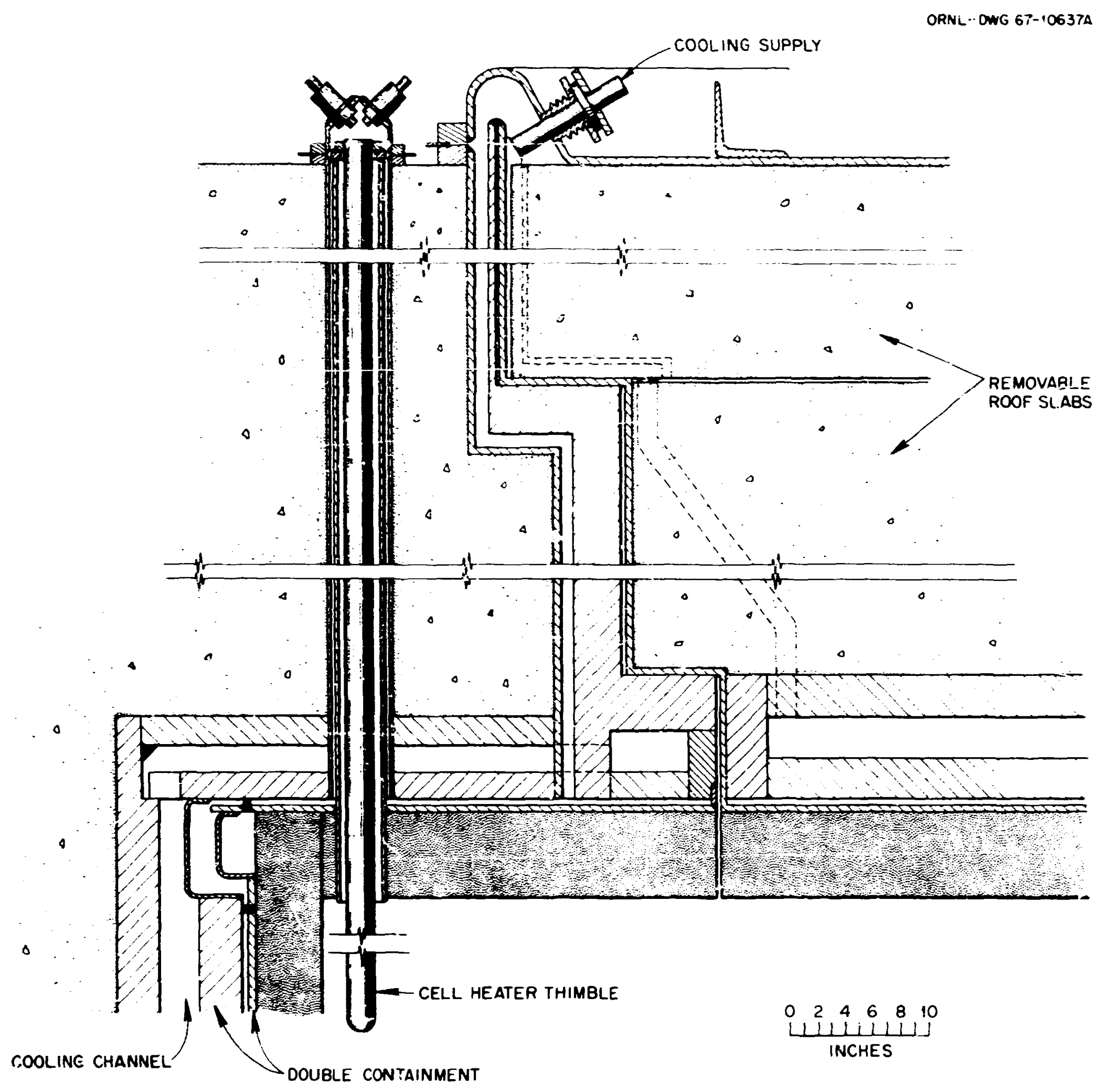

Fiz 4.10. Cell Wall Coastruction at Roof Phy.

radioactivity, however, is only that induced into the coolant salt, so there is no need for the steel radiation shield to protect the concrete. Thermal insulation would be applied in the same thickness and about the sime manner as in the reactor cell, and the liner would form the hermetic seal. A double barrier is not required for containment purposes, but an air flow passage must be provided to carry away the heat passing through the thermal insulation to prevent the concrete shielding from getting too hot.
Figures 4.6-4.8 illustrate the arrangement of equipment in the codant cell. As in the reactor cell, all components are mounted on support columns which iest on the floor of the cell. The coolant salt piping is prouded with several expansion loops to achieve the necessary flexibility without the use of expansion joirts. The expansion of the steam lines is absorbed in piping loops located outside the cell. Bellows seais are provided where the various pipes pass through the coolant cell walls. Analyses of the stresers in piping and 
equipment indicate that all are within the limits allowed by the codes.

\subsubsection{Drain-Tank Cells}

The two drain-tank cells are located as shown in Figs. 4.6 and 4.8. A cross section of the cell is shown in Fig. 4.11. Each cell is about 17 by $50 \mathrm{ft}$ with the end containing the fuel drain tanks about $73 \mathrm{ft}$ deep. The other end of the cell houses the blanket and coolant salt tanks and is about $37 \mathrm{ft}$ deep. The walls of these cells are corstructed much the same as the reactor cell walls. Double containment must be provided, and the cells must be heated to about $1190^{\circ} \mathrm{F}$.

In addition to the various sait lines entering the drain-tank cells, there are also pipes to provide for steam cooling of the tanks and for the inert gas used for pressurizing the tanks to transfer the salt. (Subsequent studies have indicated that a natural-convection salt system may be superior to a steam system for cocling the drain tanks.) Bellows seals are used where the piping passes throughi the cell walls.

\subsubsection{Off-Ges Cells}

As wil be explained in Sect. 5.5, the helium that removes the gaseous fission products from the fuel and all other contaminated gases are routed to an offess cell for filtration, decay of radioactive contaminants, and other treatment. The two off cells are approximately $17 \mathrm{ft} \times 38 \mathrm{ft} \times 62 \mathrm{ft}$ deep. The wall and roof construction is similar to the reactor cell in that double containment is provided. Since alts are not present, these cells are not heated and thermally insulated.

\subsubsection{Sait Processing Cell}

The chemicai processing piant fơr trềtumentît ố the fuel and blanket salts is contained in a single cell. As described in Sect. 4.5, the plant serves all four of the reactor modules. The cell has a $T$ shape, one leg being about $10 \mathrm{ft} \times 34 \mathrm{ft} \times 62 \mathrm{ft}$ deep and the other about $12 \mathrm{ft} \times 88 \mathrm{ft} \times 62 \mathrm{ft}$ deep.

Double containment is required, but since some pieces of equipment need to be heated and others

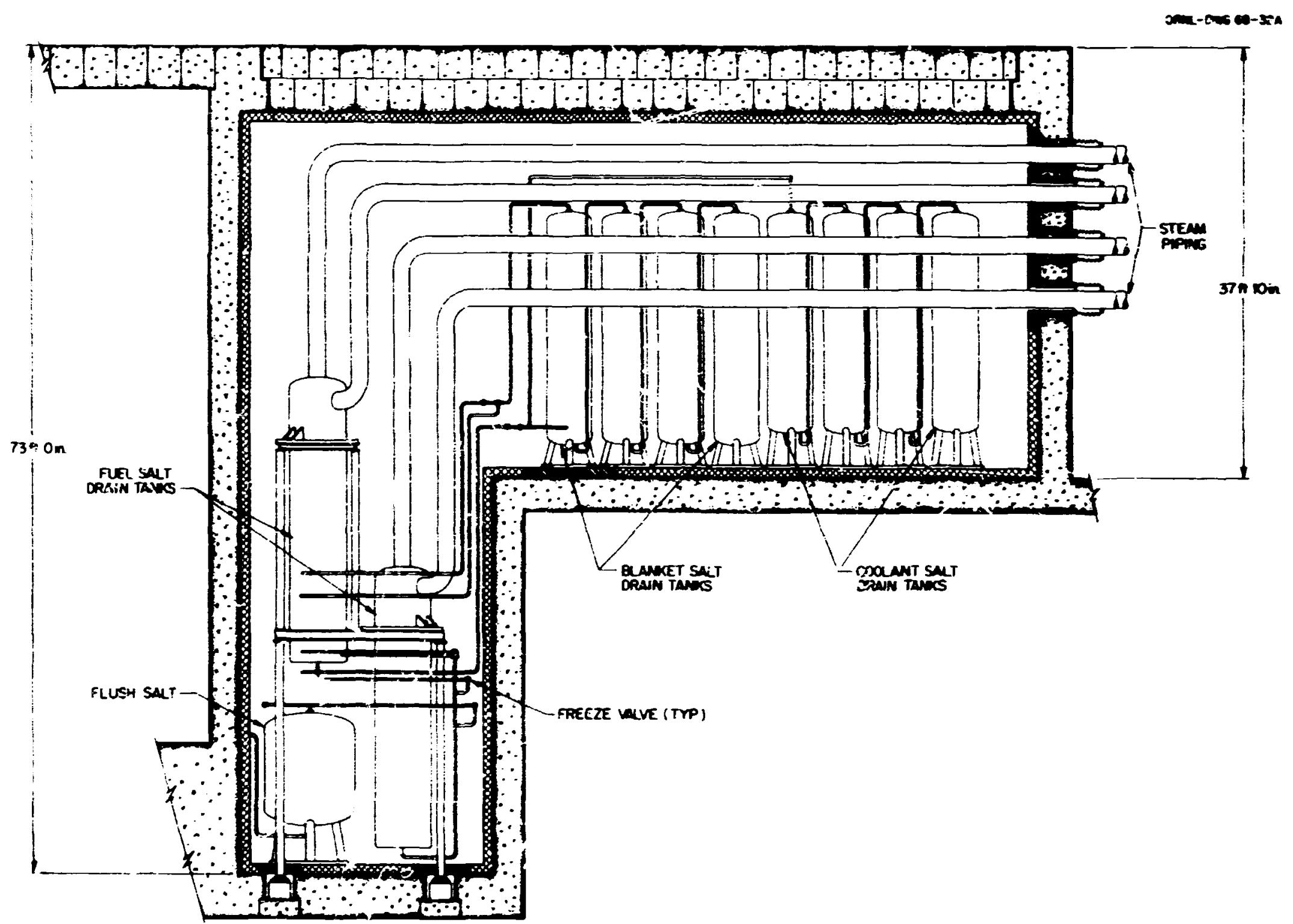

Fiz 4.1 1. Crose Sectiond Eleration of Drain Tank Cen. 
cooled, the ambient temperat ure of the cell is relatively low. The pipes and vessets would be heated or cooled individually as required. Biological shietuinty is needed because of the high lewil of radioactivity.

\subsubsection{Instrumentution Cell}

A centrally located cell is provided for the piping, junction boxes, controls, etc., associated sith tite instrinsertiun of the reactor complex. This 10- by $80 \mathrm{ft}$ cell would be operaied at normal ambient temperatures and is not a containiment area.

\subsection{9 "Hot" Storage Cell (for Reactors)}

A cylindrical cell $20 \mathrm{ft}$ in diameter by $62 \mathrm{ft}$ deep is provided at each reactor module for storage of the reacto vessels and spent graphite cores witil most of the ndicactivity decays and they can be procised for dispocal. Tre cells are hermetically sealed.

\subsubsection{0 "Hot" Cells}

A series of small cells, possibly 8 by $8 \mathrm{ft}$, are shown in Fig. 4.6 to indicate that cubicles equipped with remotely operated manipulators and other equipment will be needed for repair and inspection operations.

\subsubsection{Comtrol Rooms, Offices, Shops, etc.}

As indicated in Figs. 4.2 and 4.4, space has been allowed for control rooms, offices, laboratories, shops, stonge, etc.

\subsection{Turbine Plant}

\subsubsection{General}

A preliminary study of the MSBR turbine plant was included in ORNL-3996." This work has not yet been extended in any more detail for subsequent MSBR conceptual desigr, studies.

The steam supplied to the turbine from the steam generator cells would not be radioactive, and no reasonable accident situation can be conceived where contamination could enter the steam-circulating system. The turbine plant is thus conventional with regard to design, mointenance, and operational procedures.

The relatively high salt temperatures which are available make it possible to generate $1000^{\circ} \mathrm{F}$ steam and to reheat to $1000^{\circ} \mathrm{F}$. The upper limit on the steam teinperature was chosen more on the basis of current steam-system operating practice than on specific limitations of the salt sjstems. Double reheat would offer no appreciable technical difficulties and could be considered in future steam-systern optimization studies. Supercritical pressure was selected for the steam cycle besuse it offered better cycle efficiency, followed an established trend in the steam power industry, 20 and provided an opportunity for heating the feedwater to $700^{\circ} \mathrm{F}$.

Thi cycie provides for mixing prime steam with the feedwater to raise the temperature to the inlets of the steam generators to a woid local freezing of the coolant salt or excessive temperature gradients in tubing walls. Future development may show that lower feedwater temperatures can be used. In this case, sufficiently high feedwater temperatures possibly could be attained through additional stages of regenerative feedwater heating. ORNL $4037^{2}$ and MSR-66-18 21 discussed an altemative cycle in which $580^{\circ} \mathrm{F}$ feedwater is supplied to the steam generators and $552^{\circ} \mathrm{F}$ "cold" reheat steam is sent to the reheaters. All the feedwater heating would be accomplished by use of extraction steam from the turine. The flow through the steam generator would be reduait to about $7.5 \times 10^{6} \mathrm{lb} / \mathrm{hr}$, and the boiler feed booster pinmps would not be required. There would be 2 saving wi the cost of equipment and an increase in the net overa.' thermal efficiency from about 44.9 to $45.4 \%$.

\subsubsection{Turbine Plent Flowsheet}

The turbine plant flowsheet is shovm in Fig. 4.12, and pertinent data are listed in Table 4.1. The flowsheet is not represented to be the optimum one but rather is one that appears to be operable and one upon which preliminary cost estimates can be reasonably based.

Steam is cielivered to the turbine throttle at 3500 psia and $1000^{\circ} \mathrm{F}$. After expansion to 600 psia and about $550^{\circ} \mathrm{F}$ in the high-pressure turbine, it is preheated to about $650^{\circ} \mathrm{F}$, then reheated to $1000^{\circ} \mathrm{F}$ before returning 20 the intermediate-pressure turbines at about 540 psia. After expansion to about 170 psia, the steam crosses to the two double-flow low-pressure turbines, where it expands to about $1.5 \mathrm{in.} \mathrm{Hg}$ abs before entering the water-cooled cc ndensers. The gross generated outplit is about $1035 \mathrm{Mr}(\mathrm{e})$.

\footnotetext{
${ }^{20}$ Roy C. Robertson, Supercritical Versus Subcritical Stcem Conditions for 1020-Mw(e) and Larger Steam TurbiriaGenerator Units, MSR-68-6? (April 24, 1968) (internal correspondence).

${ }^{21}$ Roy C. Robettson. MSBR Steam System Peformance Calculatio:s, MSR-68-18 (July S, 1966) (intemal correspondence).
} 


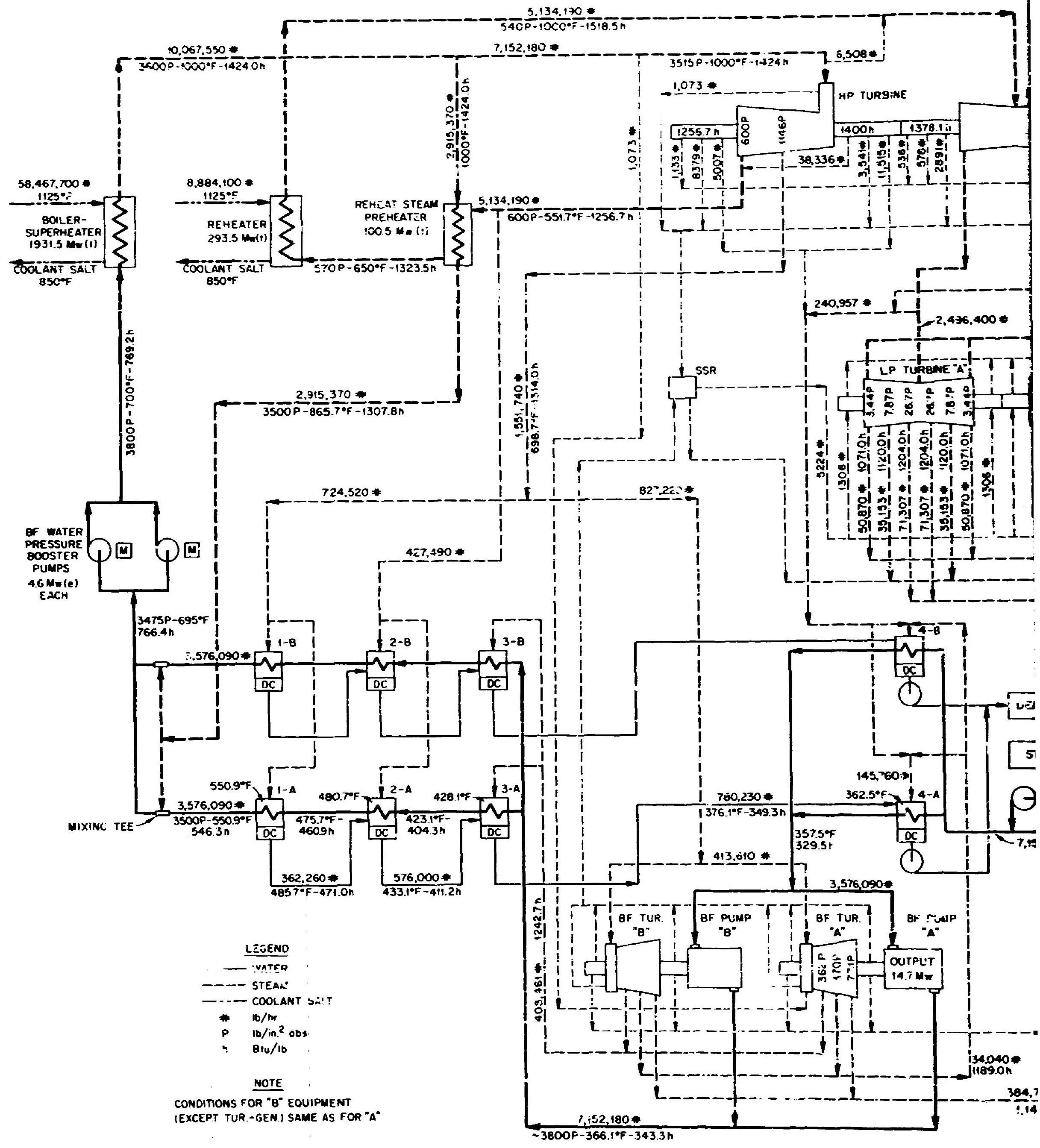

Fig 4.12. Steam System Flowsheet for 1000-4ww(e) MSBR Powe 


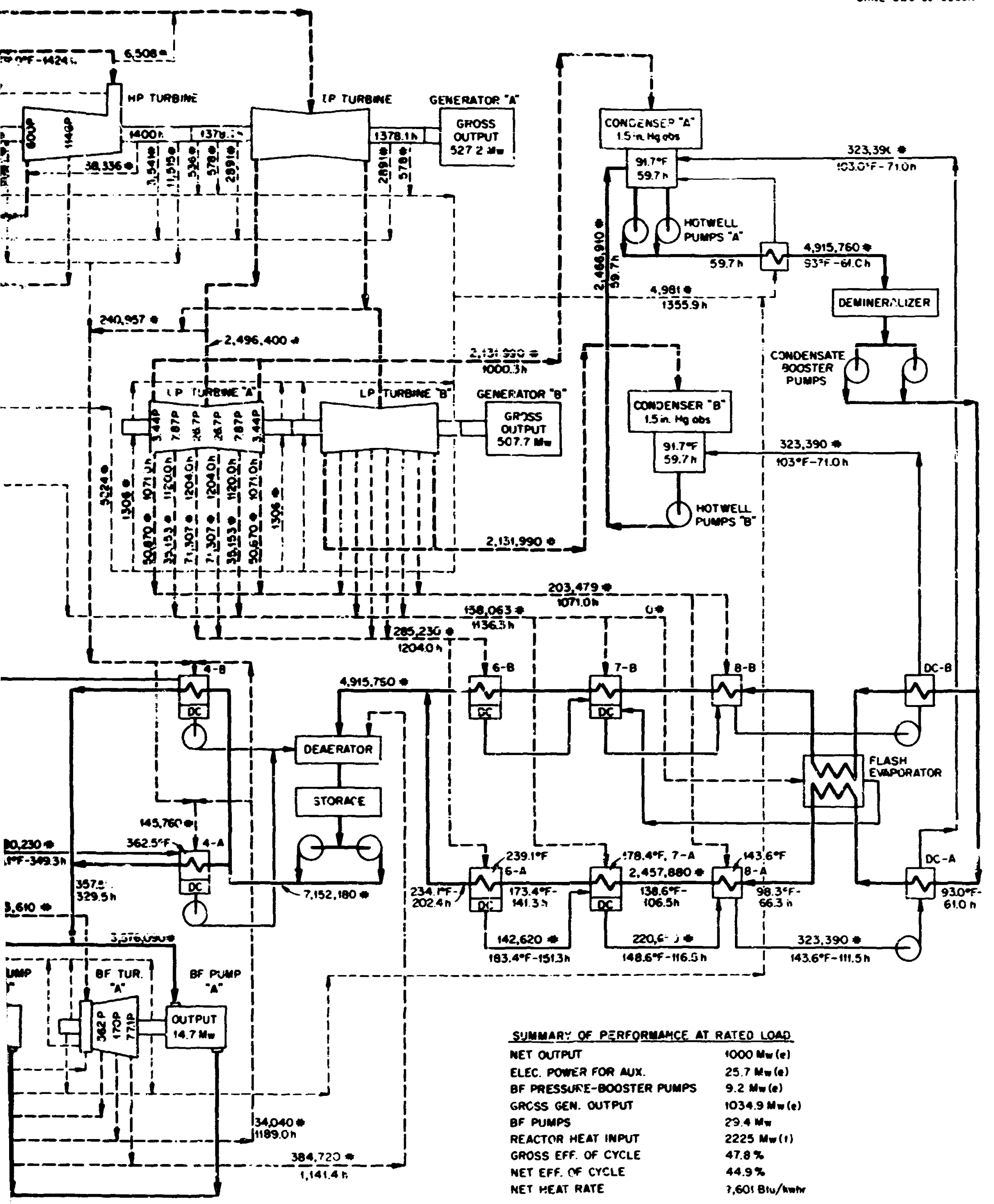

foum Plowimet for 1000-Mw(e) MSBR Power Station.

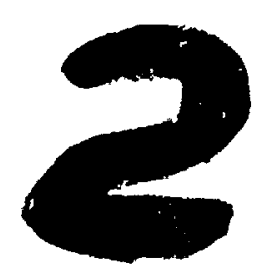


BLANK PAGE 
Table 4.1. MSBR StenonPower Syatem Darige and Performence Data with $700^{\circ} \mathrm{F}$ Foodwatex

\section{Geacal perfor mance}

Total reactc i power, Mw

Net electrical ontput, Mw

Grosis electrical seneration, Mw

Station mxining bad, Mw

Boiler feedwnter presurebooster pump loed, Mw

Boilex feadwater piup steam-turbine power output, Mw (mechanical)

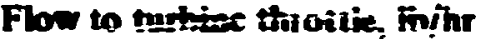

Flow trom supecheater, b/hr

Gross efincieary, \& (1034.9 + 29.3)/2225

Gross beat rate, Btu/kwhr

Net efinciency, $\%$

Net beat mite, Btw/kwhr

Boilex-mpectreaters

Number of units

foisl duty, Mw(th)

Total staen capacity, $\mathrm{tb} / \mathrm{hr}$

Temperature of inlei feed water, ${ }^{\circ} \mathrm{F}$

Enthrlyy of inet foed wnter, Bsw/bo

Presante of inlet foodwater, poin

Temperature of ontiet stean, ${ }^{\circ} \mathrm{F}$

Presince of outiet stesson, pain

Entridpy of outiet steam, Btu/lb

Tempenture of inlet coskant salt, ${ }^{\circ} \mathrm{F}$

Temperature of coithet coolent selt, ${ }^{\circ} \mathrm{F}$

A verne ppectific heat of cocioni salt. Btu $t^{-1}{ }^{0} F^{-1}$

Totel coribost alt flow

Both

ats

Ppm

Coobnt salt pitsure drop, inlet to outlet, pri

\section{Stem roheaters}

Houser of units

Total duty, Mw(th)

Total steam capacity, lb/hr

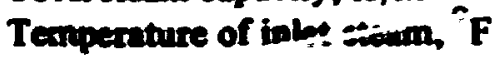

Prsince of tulet stean, poin

Exthstpy of inlet steam, Btu/h

Tempenturs of outiet steam, ${ }^{\circ} \mathrm{F}$

Premene of outiot atean, paia

Entholpy of outht steam, Btu/lb

Temperature of inlet coolant els:, ${ }^{\circ}$

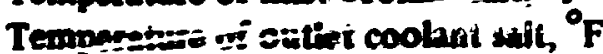

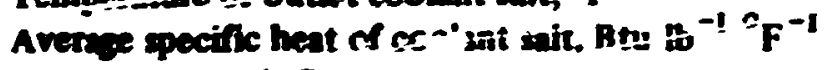

Totui coolant alt flow

b!

cts

$\cos$

Coobat wit presure drop. inlet to ouldet, pai
2225

1000

1034.9

25.7

9.2

29.3

$7.15 \times 10^{5}$

$10.1 \times 10^{6}$

47.8

7136

44.9

7601

16

1932

$10.1 \times 10^{6}$

750

769

3770

1000

$\sim 3600$

1424

1125

850

0.41

$58.5 \times 10^{6}$

130

58,300

70

8

294

$5.13 \times 10^{6}$

650

$\sim 570$

1324

1000

357

1518

i 125

850

0.41

$8.88 \times 10^{6}$

19.7

8860

$M 7$
Reheat-steam preheaters

Number of units

Total duty, Mw(th)

Total heated rteam capacity,

Temperatire of heated steam, Inlet

Outlet

Preacure of heated steam; pain Inlet

Outlet

Enthalpy of heated steam, Btu Inkt

Outlet

Total heating steam, b/hr

Temperature of beation steam, Inlet

Outlet

Presure of heating steam, poin Inlet

Ootilet

Boilex feedinater permes

Number of units

Centrivipel pump

Number of atros

Feedwater flow rate, total,

Required copecity, apan

Head, approximate, it

Spaced rpen

Water indo ienpenture. ${ }^{\circ} \mathrm{F}$

Water inbet exthslpy, Rtw/to

Water inlet epecific wolyes.

Steam-untio viro

ower requited at rated for

Power, nosnind hp (each)

Throttie stean conditions,

Throttle non, bo/hr (each)

Exhonst pressice, approxinn

Number of the

Neseber of exterection points

Boilet ferd water presure-booster

Number of units

Conirimeal pump

Feadwater flow rate total, Required capacity, epen (eaci Head, approximate, $f$

Water inlet teuperature, ${ }^{\circ} \mathrm{F}$

Water inlet presoure, pich

Water inlet spectic volume

Water outiet temperature, $\mathrm{F}$

Electric motor ditre

Power requitred at rated flow

Fowe, nominal ho (each)

Taken from ORNL-3996 (res. 1). 


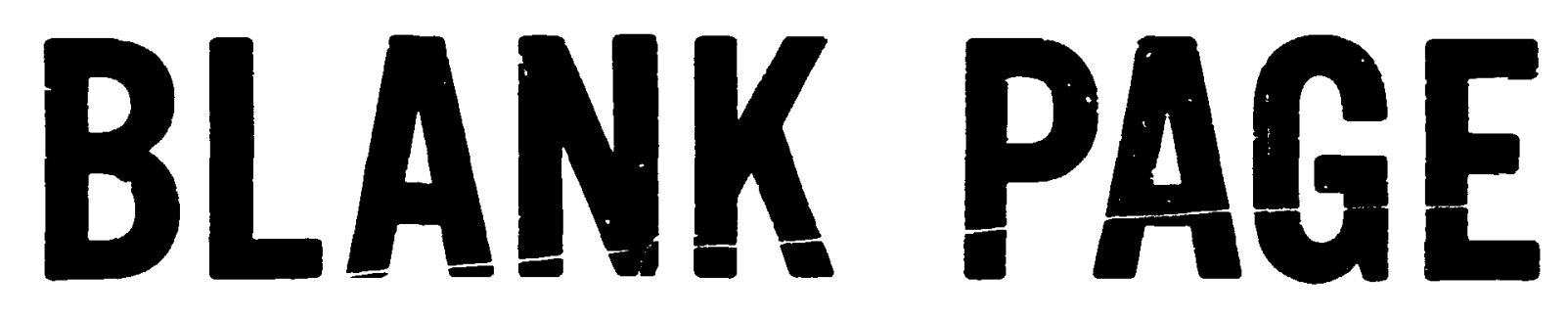




\begin{tabular}{|c|c|c|}
\hline 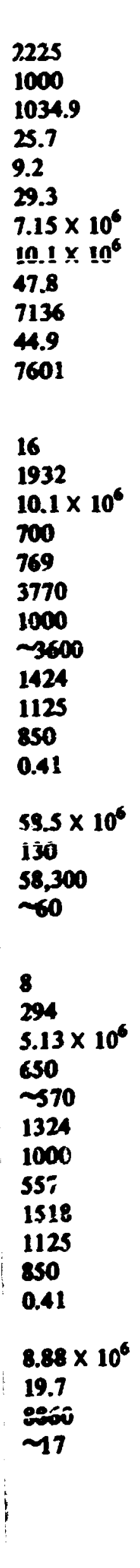 & 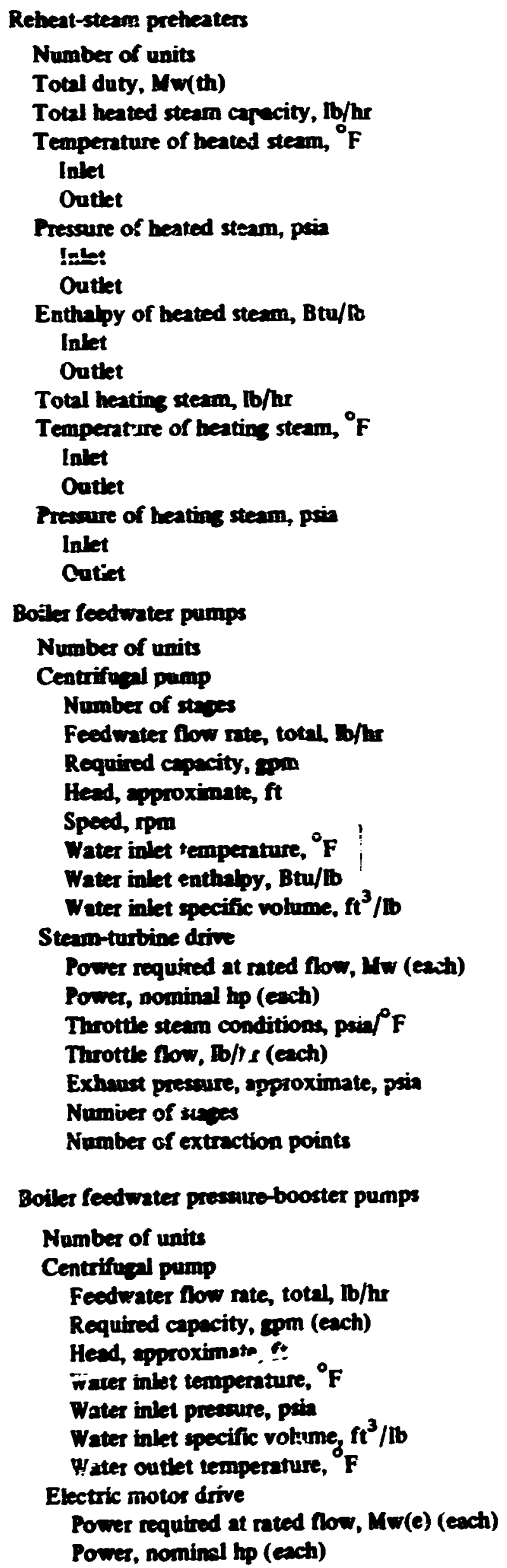 & 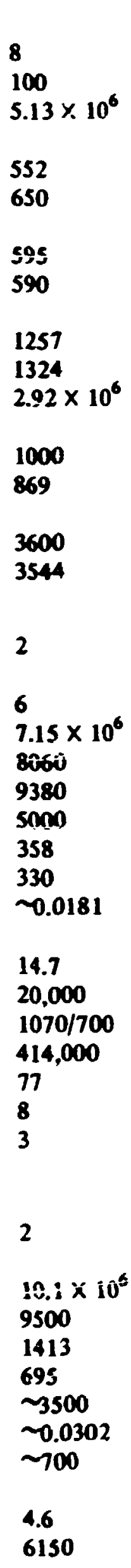 \\
\hline
\end{tabular}


The two feedwater pumps are driven by separate turbines using steam at about 1100 psia taken from an extraction point on the high-pressure turbine. (The pump turbines can also be driven by prime steam if the need arises.) The capacity of each pump is about 8000 $\mathrm{Bpm}$ and the nominal power requirement ${ }^{19} 20,000 \mathrm{hp}$ each. Eight stages of regenerative feedwater heating are used, induding the deaerator, employing steam extracted from the high- and low-pressure turbines and from the feedwater pump turbines. Full-flow demineralizers will mainta'n the foeduster puriiy to within a few parts per billion. Feedwater enters the steam generators at $700^{\circ} \mathrm{F}$.

The steam system is conventional in almost every respeci except for preneating of the reheat steam and the haating of the feedwater to $700^{\circ} \mathrm{F}$ before it enters the steam ginerators. As mentioned above, the steam to be reheated leaves the high-pressure turbine exhaust at 600 psin and about $550^{\circ} \mathrm{F}$. It is then heated on the shell siae ot two prehesters by prime steam inside the tubes. The reheat steam, now at about $650^{\circ} \mathrm{F}$ and 570 psia, enters the reheaters, where it is raised to $1000^{\circ} \mathrm{F}$ by counterflow with the coolant salt. The reheated steam retums to the intermediate-pressure turbine at $1000^{\circ} \mathrm{F}$ and 540 psia.

The throttle-pressure heating steam leaving the tubes if the preheater mentioned above, now at about $866^{\circ} \mathrm{F}$, $s$ directly mixed with the feedwater leaving the top extrartion heater at about $550^{\circ} \mathrm{F}$ and 3475 psia. Since both sireams are ai supeicintical pressire, the mixing an be accomplished simpiy. The resuiting sตร $^{\circ} \mathrm{F}$ mixture is then raised to 3800 psin and heated an additional $5^{\circ} \mathrm{F}$ by two boiler feedwater pressure-booster f'mps operating in parallel. These $9500 \mathrm{gpm}$ pumps are shown on the flowsheet as driven by electric motors (about $6000 \mathrm{hp}$ each) but in an optimized system could very well be steam-turbine driven.

\subsubsection{Layout of Turbine Plant}

The relatively high efficiency of the turbine plant and use of a 3600-rpin turbine-generator make the space requiremints for the turbine plant less than for the turbine-generator in a water reactor plant of the same capacity. The layout of the plant, indicated in Fig. 4.4, is substantially the same as for a conventional station. The feedwater heaters, pumps, water treatment equipment, etc., would be located on several floor levels of a building bay provided for this purpose. Use of a tandem-compcunded turbine-generator sather than a cross-compounded unit would not require significant alterations to the layout shown.

\subsection{Salt Processing Plant}

\subsubsection{Gereand}

A mojur attractive feature of the two-fluid MSBR is the reiative ease with which the fuel and blanket salts can be processed to remove fission preducts, recover the bred product, and add new fuel. For the reactor to be a high-performance breeder, the processing must take place on a fairly rapid cyde and with low holdup of ${ }^{233} \mathrm{U}$ in the processing equipment. A dosely knit complex of MSBR power stations might make use of a central processing facility, but the MSER concept described here assumes that the processing plant is part of the 1000-Mw(e) station and serves only the four reactor modules.

Small side streams of salt are taken from the ivel and blanket salt circulating systerns for processing in ain adjacent cell. A relatively small space is needed for the processing equipment. A cell having or s space about 10 $\mathrm{ft} \times 34 \mathrm{ft} \times 62 \mathrm{ft}$ deep and another $12 \mathrm{ft} \times 88 \mathrm{ft} \times 62$ $\mathrm{ft}$ deep is provided in Fig. 4.6.

Many of the station facilities such as offices, shops, laboratories, electrical and water services, waste disposal, data logging and analysis equipment, ete., are shared by the reactor and salt processing plants.

\subsubsection{Fuel Salt Procesing}

Almost all the fissicns occur in the fuel salt, and the objective of the fuel salt procossing is to keep the fission product conontrations at a low snough level for the neutron losses to be acceptabiy low. This must be accomplished economically and with low losses of ${ }^{233} \mathrm{U}$ and LiF-BeF 2 carrier salt. The gaseous fiscion products, krypton and xenon, are removed continuously from the circulating fuel in the reactor as described in Sect. 43.1. In the processing plant the fluoride volatility process and vacuum distillation are used to separate the ${ }^{233} \mathrm{U}$ and the carrier salt from most of the remaining fission products. Discard of a small amount of carrier salt is required to remove fission products that distill with the lithium and beryllium fluorides.

An overall flowsheet for the salt processing plant is shown in Fig. 4.13. The fuel salt is drawn semicontinuously from the circulating systems of the four reactor modules at : combined rate of about $24 \mathrm{ft}^{3} /$ day (corresponding to a 60-day cycle for a reactor with an average power density of $20 \mathrm{kw} / \mathrm{liter}$ ) and is collected in a holdup tank in the salt processing cell. Since the reactants used in the processing are not damaged by irradiation, it is not necessary to provide decay time for 


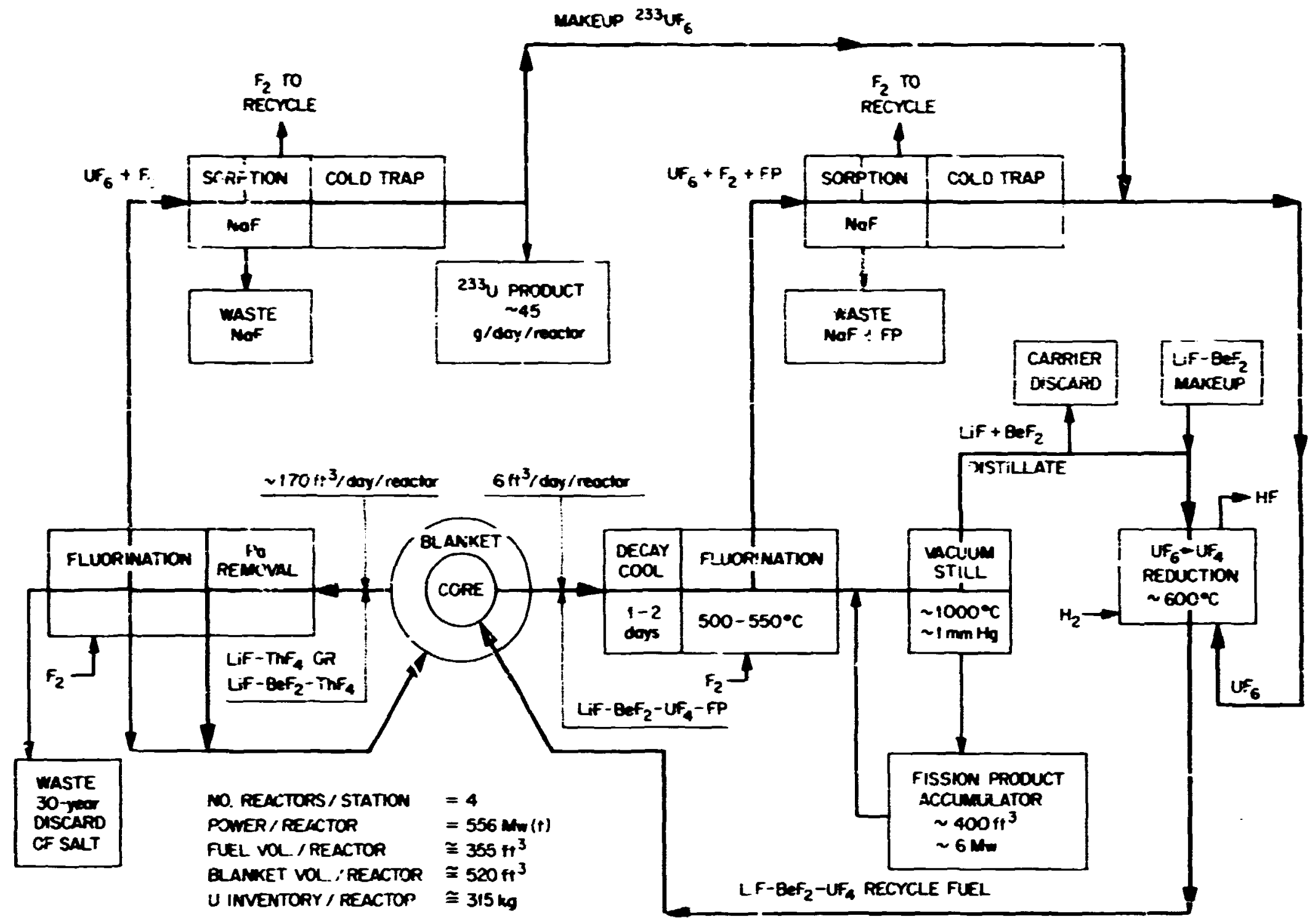

Fig. 4.13. Procening Diogrm for TwoFlaid MSBR.

this reason, but up to $24 \mathrm{hr}$ decay may be required for the fission product heating to be reduced to a level that will allow proper control of the temperature in the fluoriration process. Removal of decay heal is a privicipal design consideration for the holdup tank and for other equipment in the fuel salt processing plant.

Silt is drawn from the holdup tank into the processing equipment continuously. Some of the processing operations are of the batch type, but continuous flow is achieved through the use of parallel flow paths and altemate sets of equipment. First, the salt flows to the sop of a fluorination column, where it is sontacted by a stream of fluorine flowing countercurrent to the salt. The temperature is controlled at about $550^{\circ} \mathrm{C}$. The uranium in the salt reacts with the fluorine to produce volatile $\mathrm{UT}_{6}$, which is cariied overhead by an excess flow of fuorine. The uranium removal efficiency is about $99.5 \%$. Two types of continuous fluorinators are promising for this application: a falling-drop type, described by Mailen and Cathers, ${ }^{22}$ and one in which the wall of the fluorinator is cooled to produce a $3 / 4$-in.thick layer of frozen salt to protect the metal from corrosion.

Volatile fluorides of ruthenium, niobium, molybde. num, technetium, and tellurium are swept out with the UF $_{6}$. Fission produrs iodine and bromine are also presint in the gas. The carrier salt, barren of uranium but containing most of the fission products, flows out the bottnm of the column for subsequent purification in a vacuum still.

The $\mathrm{UF}_{6}$ is separated from the other volatile fluorides in a series of sorption and desorption opersitions. The gas is first passed over pellets of sodium. fluoride at

\footnotetext{
22 J. C. Mailen and G. I. Cathers, Fluorimation of Falling Droplets of Molten Fluoride Salt as a Means of Recovering Uronium and Plutonium, ORNL-4224 (November 1968).
} 
3bout $400^{\circ} \mathrm{C}$, where the Tuorides of niobium, rutinenium, and tellurium are in 'versibly removed. When the bed becomes loaded with fission products, it is discharged to waste and refilled with fresi pellets. The exit gas then flows over a bed of socium fluoride pellets mantained at about $100^{\circ} \mathrm{C}$, where the $\mathrm{UF}_{6}$ and $\mathrm{MoF}_{6}$ are surbed. When this lowtemperature bes tuecoumes saturated with $\mathrm{UF}_{6}$, it is taken off stream and the temperature is raised sowly to about $150^{\circ} \mathrm{C}$ to selectively desorb the $\mathrm{MoF}_{\mathrm{s}}$. The temperature is then increased further to drive off the $U_{6}$, which is onllected in cold traps at -40 to $-60^{\circ} \mathrm{C}$. When a cold trap is loaded with $\mathrm{JF}_{6}$, it is warmed to the triple point ( $90^{\circ} \mathrm{C}$, 40 psia), arainea to the reduction unit ior reconstitution of the fuel salt, and then recyded to the ractor. The fivorine carrier gas leaving the lowtemperature sodium fluoride bed is recycled to the fluorinator. Radioactive technetium, iodine, and bromist remaining in the recycled gas decay somewhat, but about $10 \%$ purge and makeup with fresh fluorine is required to keep tine concentraions of these gases within the desired limits.

The carrier salt, on leaving the bottom of the fluorirator, enters a youisin siii that is operated at about 1 torr and $1000^{\circ} \mathrm{C}$. Most of the beryllium fluoride and lithium fluoride distill, leaving behind the rareearth fluorides, which would have been the principal neutron poisons in the reactor. The bottom liquid is reçycied through the stiil and a decay tank as necessary to control the heating by fission products. The decay tank has a volume of about $400 \mathrm{ft}^{3}$; which is judged sufficient io collect the fission products over the 30-year life of the plant. At the end of this time, the lithium fluoride and beryllium flworide in this waste can be recovered, and the fission products can be packaged for permanent disposal.

The distilled lithium and beryllium fluorides contain small amoun is of cesium fluoride and rubidium fluoride and some zir:onium fiuoride. A small fraction (no more than 5\%) of the carriet salt is jiscarded to purge this poison. The very small amount of UF, in the carricr salt that enters the still is also partially volatilized and recovied.

The lithium fluoride-beryllium fluoride distillate and the $\mathrm{UF}_{6}$ from the cold traps are added continuously in the proper proportions to a reducer, where the fuel salt is reconstituted for retum to the reactor nodules. The $\mathrm{UF}_{6}$ is dissolved in the salt at about $600^{\circ} \mathrm{C}$ and reduced to UF, by addition of hydrogen and discharge of hydrogen filuoride. The conditions in the reducing column precipitate nickel and iron that are present as fluorides due to corrosion of the processing equipment.
A filter after the reduction unit removes metallic precipitates from the fuel salt before it is retumed to the reactor modules.

Experience with batch processing by the fluoride volatility method dates oack to 1954 and indudes all phases of bboratory and dewlopent not and sin-

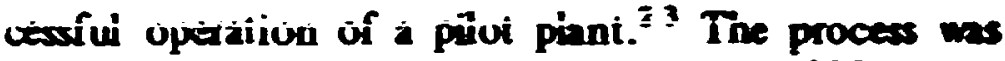
demonstrated on a large sale in recovering ${ }^{235} \mathrm{U}$ from the fuel salt in the MSRE. The principles of continuous fluonnation have been demonstrated in the hboratory. Separation of lithium and beryllium fuorides from rare-arth Ession products by vacuum distillation ins been investigated in the bboratory and has been vermorstrated in an engineeringsale unit by distilling abuut half a cubic foot of salt from the MSRE. ${ }^{24}$ The reconstitution of fuel salt by kydrogen reduction of UF $_{6}$ in carrier salt has been demonstrated in the laboratory.

\subsubsection{Blanket Salt Psocesaing}

The ${ }^{233} \mathrm{U}$ in a two-fluid breeder is produced by the reaction

${ }^{232} \mathrm{Th}+n \stackrel{\gamma}{\rightarrow}{ }^{233} \mathrm{ih} \frac{\beta}{23 \mathrm{~min}}{ }^{233} \mathrm{~Pa} \frac{\beta}{27 \text { days }}{ }^{233} \mathrm{U}$.

All the ${ }^{233} \mathrm{U}$ is produced in the blanket alt. A major objective of the blanket sil processing is to recover the ${ }^{233} \mathrm{U}$ about as rapidly as it is produced in order to make it avilable for addition to the fuel alt to compensate for burnup. Rapid procescing reduces the inventory of ${ }^{233} \mathrm{U}$ in the plant and the amount of fissioning that occurs in the blanket salt. The latter is important because thorium is difficult to separate from the rareearth fission products except by aqueous processes, and accumulation of fiscion products in the blanket salt would adversely affect the breeding performance.

The major objective can be achieved by procescing the blanket salt to remove ${ }^{233} \mathrm{U}$ alone or to remove ${ }^{233} \mathrm{~Pa}$ and ${ }^{233} \mathrm{U}$. Removal of ${ }^{233} \mathrm{U}$ alone can be accomplished by the proven fluoride wolatility process, and $t+$ is is the method that was proposed for the two-fluid MSBR in ORNL-3996.' This choice, however, places certain

\footnotetext{
${ }^{23}$ W. L. Carter and M. E. Whatiey, Fud and Blanker Irocessiris Development for Molven Salt Breeder Rewctors. ORNL-TM-1852 (June 1967).

${ }^{24}$ W. L. Carter, R. B. Lindsuer, and L. E. McNeex, Dedion of on EngineeringScale, Vecuum Dtalledon Expertment for Moltensalt Reactor Fud, ORNL-TM-2213 (November 1968).
} 
restrictions on tie dexion of a breeder reactor. The volume of binke: silt in the low-flux region of the reactor bhnket, $x$ in tanks ouiside the reacto: ressel, mose be large enough so that the average thermal neutron flux neutrons $\mathrm{cm}^{2}$ or leas, if the lows by neutron absorption to form ${ }^{234} \mathrm{P}$ is to be kept belor $0.5 \%$. The ${ }^{23}{ }^{3} \mathrm{U}$ in the blanket alt must be removed on about a 20-day cyise in order to keep the fiscioning to a very low rate.

Removel of the ${ }^{233} \mathrm{~Pa}$ ss well as the ${ }^{233} \mathrm{U}$ froin the blenket salt can reduce the wolume of blanket salt required and the thorium inventory by a factor of 2 to 3. Such a process has been onnoeived, and ite hasir principles have been demoisituated in the bboratory. This is now the preferred method for processing the binket silt for the two-fluid MSBR and is induded in the flowsheet of Fig. 4.13.

The protactinium removal must be on a short cycle to be fully effective, possibiy as rapid as treating the entire blanket inventory once every three days, or at 3 rate of about $3.6 \mathrm{gpm}$. The silt is continuoudy withdrawn froin the blanket circulating system and enters the bottom of an extraction column to contact a descending stream of liquid biemuth which contains 3000 to $4000 \mathrm{ppm}$ of metallic thorium. The protactinium and the small amount of uranium in the blanket alt are reduced to metal by the thorium and dissolve in the bismuth. The thorium that is oxidized enters the slt. Thorium is an ideal reductant because the removed protactinium is replaced by an equivalent amount of the fertile material. About $96 \%$ of the protactinium and uranium are removed by the process. The protactinium and uranium now in the bismuth are extracted into a second salt mixture; the protactipium is allowed to decay to uranium, which is released by fluorination to become the plant product and replacement fiscionable material in the fuel salt.

The bulk of the blanket salt with most of the protactinium and uranium removed is returned to the reactor systems, but a small portion is taken off and discarded to remove accumulated fission pioducts. This salt is stored until the residual protactinium decays, and the uranium is recovered by fluorination before the salt is discarded.

\section{MAJOR COMPONENTS}

\subsection{Reactor}

In a moltenealt breeder reactor the ${ }^{233} \mathrm{U}$ fiscions in the fuet alt and heats the salt as it flow. through grapisite elements in the reactor vessel. Hie considered severl designs for the reactor vesued and the arrangement of the gre thite. Two decigns fimilly evolved. One desifon is considerably les complicated, but the nuclear charecteristic are more affected by changes in the dimenaions of the graphite. In the other, radiationinduced changes in the dimensions of the graphite are almust fully compenonted and would have little effect on the nuciear characteristios of the reactor. The less complicated design is discussed first.

A vertical section through the center of the reactor vessed for one module of a $1000 \mathrm{Ma}$ (e) ptant is shown in Fiz. 5.1, and a horizontal section is shown in Fig.

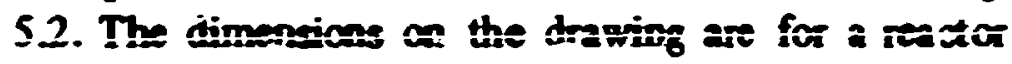
with an average power density' of $20 \mathrm{kw} / \mathrm{liter}$ in the core. Some dimensions for reactor vessets with other power densities are shown in Tabie 5.1. The vessel is made of Hastelloy $\mathbf{N}$ and is almost completely filled nith graphite dements or cells. The central portion of the reactor core contains the fuet cells. These are surrounded by several ruws of blanket cefls. A graphite reflector is interposed between the blanket and the ressed wall. Blanket salt fills most of the volume of the vessed aibove and below the graphite elements.

Fud alt enters the vessel through 2 plenum in the bottom, flows through the fuel cells, and leaves through a second plenum, also in the bottom of the vessel. The blanket alt enters the vesed throught the side near the top and flows downward along the wall to cool it. The salt then flcws upward through the blanket cells and through the apaces between blanket cells and between fuel cells and leaves the veseel through the side near the top. The channels through the bianket eiements and ine spaces between blanket elements are restricted at the top in order to direct most of the flow through the spices between core elements where the heat production rates are greatest.

In molten alt breeder reacturs the major changes in reactivity are made by adjusting the composition of the fuel alt. Control rods are primarily for making minor changes in reactivity such as those required for adjusting the temperature during operation and for holding the reactor subcritical at temperatures near th: operating temperature. The design requirements for the control rods have not been studied in detail. Since one rod in the center of the core can have sufficient worth for the easily defined requirements, only one is shown in the design. It in envisioned a a graphite cylirder about $4 \mathrm{in}$. in diameter that would operate in stanket alt. The rod would move in a graphite sleeve, and provision would be made for good circulation of blanket salt through the sleeve. Inserting the rod would iscrease, and withdrawing the rod would decrease, the 


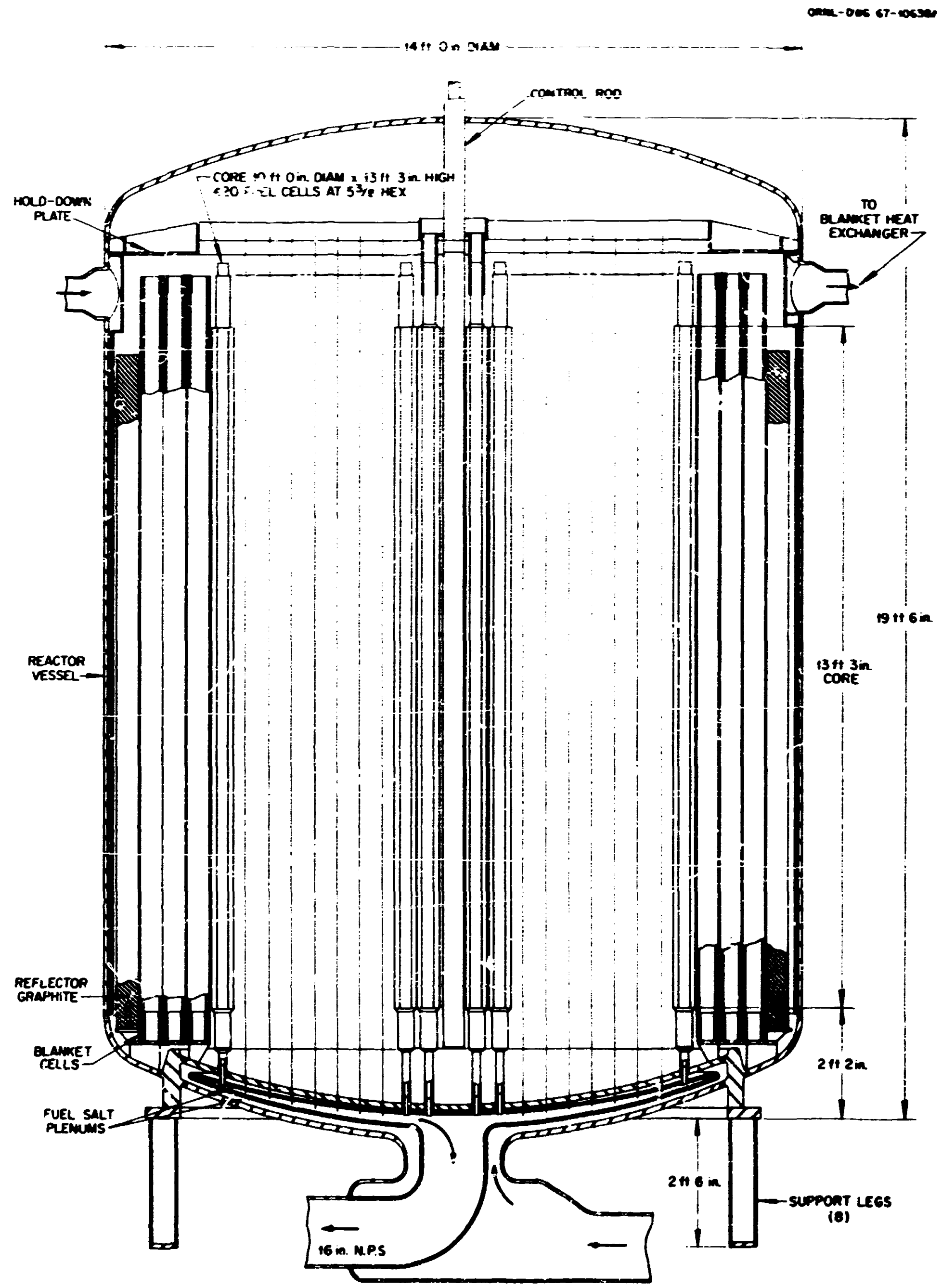

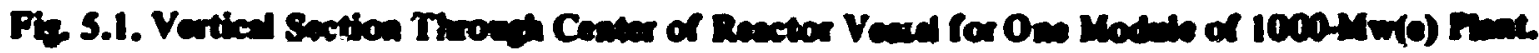


OPNL-0.6 67- ro643A

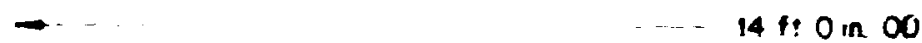

$14 f: 0$ in 00

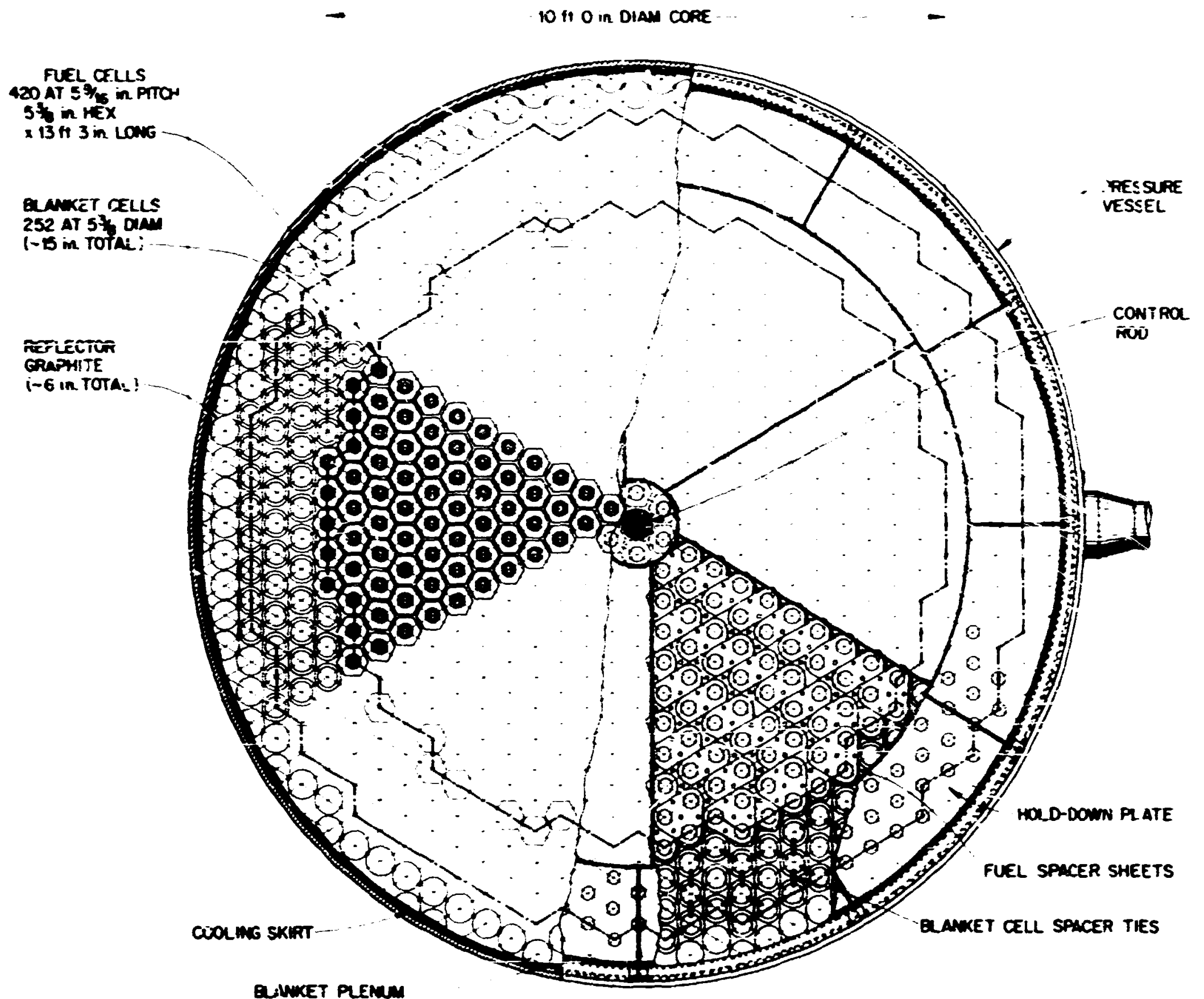

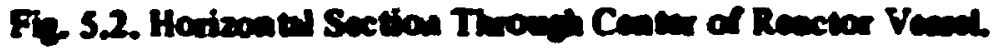

reactivity. Rapid movement does not appear to be necesarary.

A sectional drawing of a graphite fuel cell is shown in Fis. 5.3. For the reactor with an average power dencity of $20 \mathrm{kw} /$ liter, the cell has outer hexponal tube $5 \%$ $i \therefore$ across flats with a $2^{23} / 32$ in. dinm bore. Inside this tube is a concentric tube $2 \%$ in. OD by $1 \frac{1}{2}$ in. ID. The hexyond section of the elemetit is sbout 1 is if if long; end secions are reduced in dimmeix to provide for binket regions at the top and bottom of the core. The outa gnphite tube is breed to a metal piecs at the bottom end, and this piece is welded into the fuet indet plenum. The inner gaphite tube is a diding fit ove a metal tube that is waded into the fuel outlet plenum. Fud low in and upward through the annulus between the concentric tubes and downward and out through the bore of the inner tube.

The fud cells are arranged in the core on a triangular epacins of $5 \%$ in. pitch, 20 that the volume fractions se 0.02 saphite, 0.134 fuel ale, and 0.064 blank t wh. The bianket elements are simple cylindrical tubes $5 \%$ in. OD by $3 \%$, in. ID, abo arranged on $5 \%$ in. trianglar pitch. This provides volume frections of 0.58 benket alt and 0 A2 graphite in the blanket region. For 
Table 5.1. Variation of Some Reactor Charecteristics with Ponse Disity and Design Lifetime

Bhank spaces in table represent data that were not fully civelopied since the reference desizn was taken as the $20 \mathrm{kw} /$ biter case

\begin{tabular}{|c|c|c|c|c|}
\hline Average core power density; kw/liter & 10 & 20 & 40 & 80 \\
\hline Design lifetime, full-power years & 17.2 & 8.6 & 4.3 & 2.2 \\
\hline Power, $\operatorname{Mw}(t)^{e}$ & 556 & 556 & 556 & 556 \\
\hline Core diameter, $\mathrm{ft}$ & 12 & 10 & 8 & 6.3 \\
\hline Core beight, ft & 18 & 13.3 & io & 8 \\
\hline Core volume, $\mathrm{ft}^{3}$ & 2036 & 1041 & 503 & 253 \\
\hline Fraction fuel in core & 0.098 & 0.134 & 0.154 & 0.165 \\
\hline Fraction blanket in core & 0.058 & 0.064 & 0.067 & 0.06 \\
\hline Binnket thickness, $f t$ & 1.0 & 1.25 & 1.25 & 1.35 \\
\hline Fractioñ she in thanket vouturne & & 0.58 & & \\
\hline Fraction salt in graphite & & 0.42 & & \\
\hline Number fuel cells in core & & 240 & & \\
\hline Number blankst cells in core & & 252 & & \\
\hline Overall length of fuel cell, ft & & 15.3 & & \\
\hline Overall length of blanket cell, ft & & 15 & & \\
\hline Reflector thickness, $\mathrm{ft}$ & & 0.5 & & \\
\hline \multicolumn{5}{|l|}{ Fuet-alt volumesb } \\
\hline $\begin{array}{l}\text { Reactor core, } \mathrm{ft}^{3} \\
\text { Prenums and piping, } \mathrm{ft}^{3} \\
\text { Heat exchangess and pumps, } \mathrm{ft}^{3} \\
\text { Procesiain plant, } \mathrm{ft}^{3} \\
\text { Total, } \mathrm{ft}^{3}\end{array}$ & & $\begin{array}{l}139 \\
37 \\
160 \\
6 \\
355\end{array}$ & & \\
\hline \multicolumn{5}{|l|}{ Salt procesaing cycle times, days } \\
\hline $\begin{array}{l}\text { Fuel stream } \\
\text { Fertile tream } \\
\text { Pu remoral stroam }\end{array}$ & $\begin{array}{l}173 \\
144 \\
1.4\end{array}$ & $\begin{array}{l}110 \\
110 \\
1.1\end{array}$ & $\begin{array}{l}7 i \\
70 \\
0.7\end{array}$ & $\begin{array}{l}50 \\
50 \\
0.5\end{array}$ \\
\hline Breeding ratio & 1.05 & 1.06 & 1.06 & 1.05 \\
\hline Fuel yield, \% per yea & 2.75 & 4.07 & 5.01 & 5.59 \\
\hline Fuel cycle cost, miljo/kwhr & 0.6 & 0.5 & 0.5 & 0.4 \\
\hline Fiveile inventory, ks & 413 & 315 & 261 & 220 \\
\hline Fertile imentory, k8 & 63,000 & 54,000 & 39,000 & 31,000 \\
\hline Specific power, $M w(t) / k 8$ & 1.35 & 1.77 & 2.13 & 2.53 \\
\hline Average flux, $>0.82 \mathrm{Mev}, 10^{13}$ neutrons $\mathrm{cm}^{-2} \sec ^{-1}$ & 1.77 & 3.33 & 6.72 & $\$ 2.1$ \\
\hline$>0.50 \mathrm{kev}, 10^{14}$ newtrons $\mathrm{cm}^{-1} \sec ^{-1}$ & 0.50 & 0.94 & 1.90 & 3.70 \\
\hline
\end{tabular}

The design thetime is based on an allowable fluence of $5.1 \times 10^{22}$ neutrons/ $\mathrm{cm}^{2}$ (see ref. 15, Sert. 3.4).

ber reactor module.

reactors with core power densities different from 20 $\mathrm{kw/liter,} \mathrm{the} \mathrm{dimenaions} \mathrm{of} \mathrm{the} \mathrm{fuel} \mathrm{and} \mathrm{blanket} \mathrm{celb}$ and their spacings are adjusted to provide the desired sizes of core and tlanket and volume fractions of materiaks.

Ir Sect. 3.4 we indicated that the graphini could be expected to contract and then expand when irradiated in the core of ai MSBR. The useful life for decign purposes is assumed to be the time for graphite to be imadiated to a fluence of $5.1 \times 10^{22}$ neutrons $/ \mathrm{cm}^{2}(E$
$>50 \mathrm{kev}) .^{25}$ With $\mathrm{Puence}$ limiting, the design lifetime of the graphite varies inversely with the damage flux, whict in turn is proportional to the power density in kilowatts per liter of core volume. By properly varying the volume fractions of fuel and blanket salt with position in the core, a ratio of maxinum to average puwer density of 2 can reasonably be nbtained. A core

\footnotetext{
${ }^{25}$ See ref. 15, Sect. 3.4, rebative to current values for limitins neutron fivence.
} 


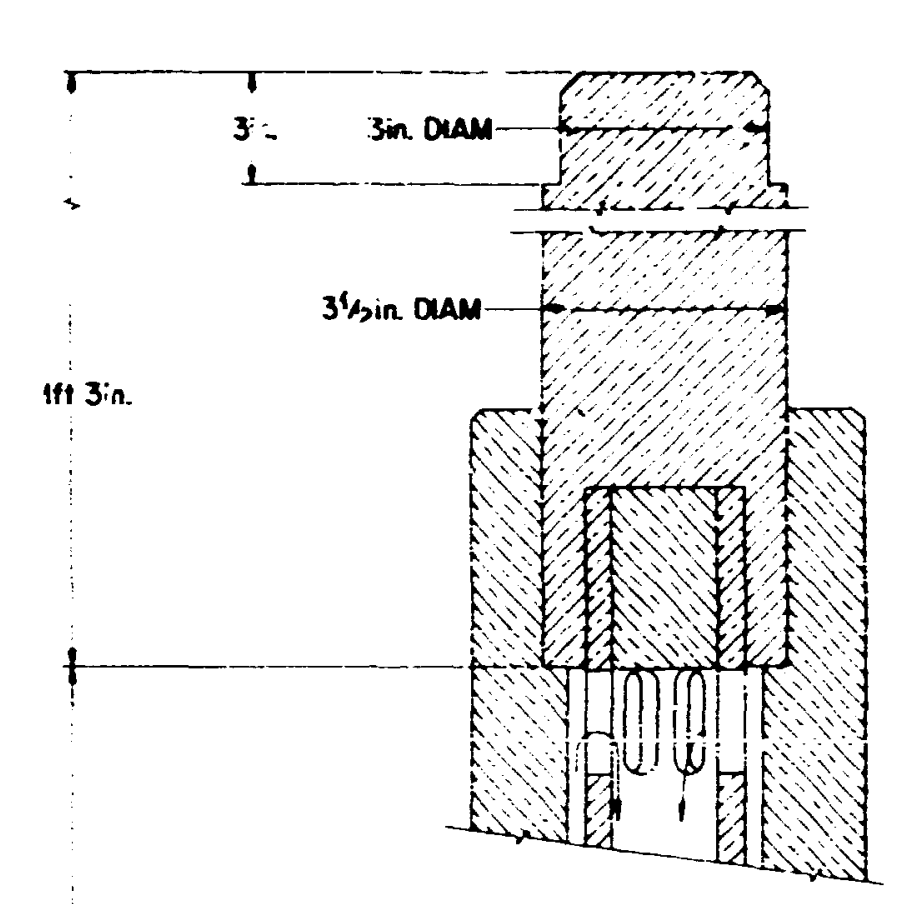

OANR-DWG 67-10546A

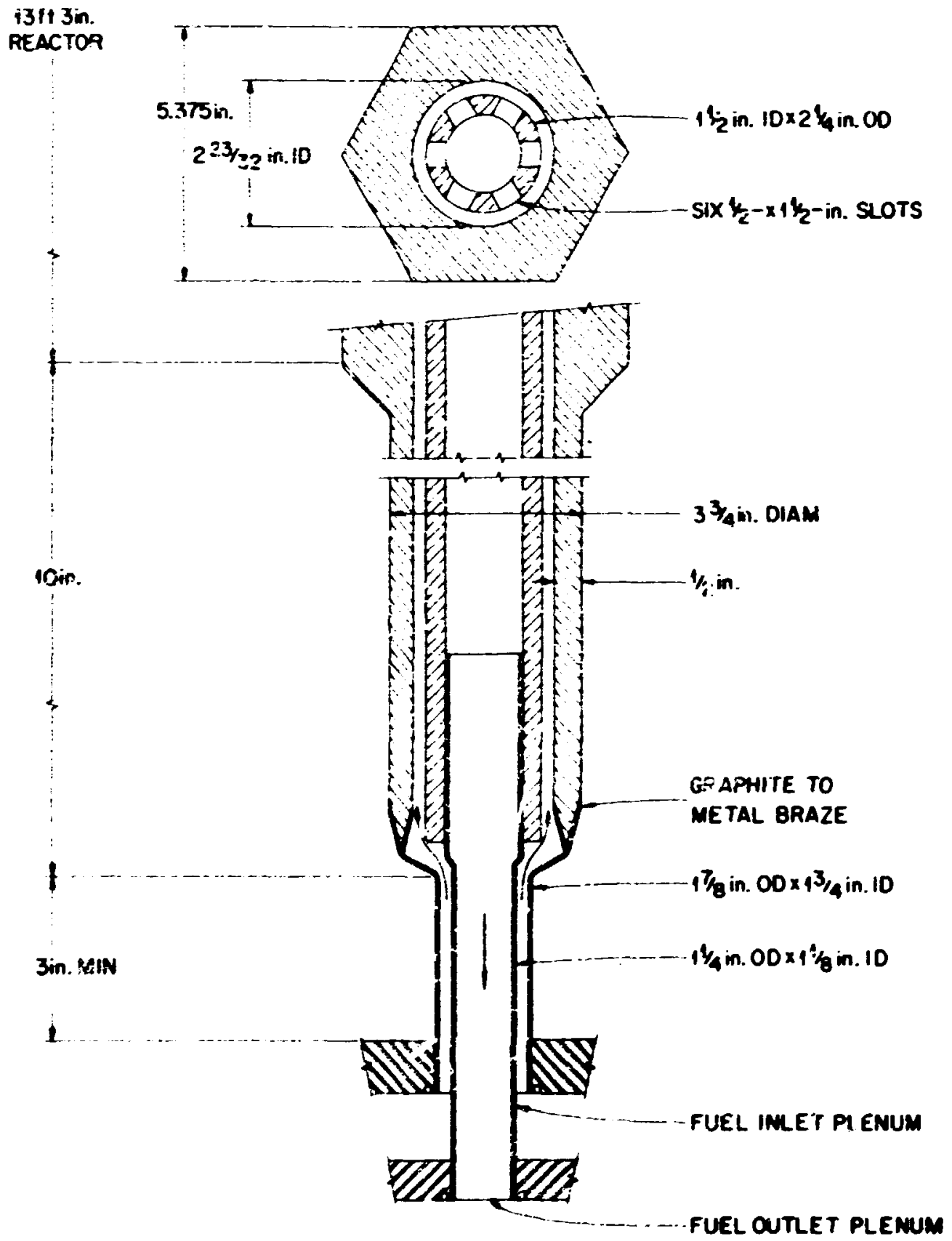

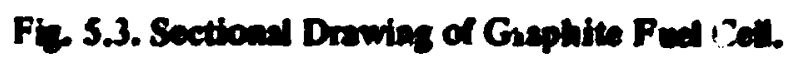


with an average power density of $20 \mathrm{kw} / \mathrm{liter}$ would have a maximum powe density of $40 \mathrm{kw} / \mathrm{hiter}$, a ma: imum damage flux of $1.9 \times 10^{14}$ neutrons $/ \mathrm{cm}^{2}$, and a design lifetime oi 8.6 full-power years, or 10.8 years with an 0.8 plant factor. Table 5.1 shows how some of the characteristics of a reactor for one module of a $1000-\mathrm{Mw}(e)$ plant would vary with average power density and design lifetime.

Inder irradiation the isotropic graphite being considerea st the time of these studies would decrease in volume by ?.5\% during the contraction stage and then wouid increase in volume by as much as $7.5 \%$ over its initial volume by the end of its useful life. These changes in volume correspond to changes in linear dimensions of $\pm 2.5^{\circ}$, urer the initial dimensions and create several design problems. The overall lengths of the graphite fuel cells would change by several is ches during the lifatime of a core and would vary with location in the reactor. We preferred not to we a bellows in the fuel salt line to each fuel cell and favored a minimum number of graphiteto-metal seak. We therefore chose to have the fuel enter and leave the bottom of the fuel cell so that each clement would have only one metal to zaphite brazed joint and the graphite would be free to contract and expand axially, as shown in Fig. 5.1.

The change in ndinl dimensions presented a mure difficult problem. Densification of the graphite to produce a $2.5 \%$ reduction in distance across the flats of the hexagonal tubes would cause the fraction of the cross section of the core occupied by fuel celts to decrease by $5 \%$, and the space occupied by the blanket salt would increase coitespondingly. For the reactor with an average power density of $20 \mathrm{kw} / \mathrm{hit}=\mathrm{r}$, the volume fractions in the core would change from 0.002 to 0.762 for graphite, 0.134 to 0.127 for fuel sait, and 0.064 to 0.ii i for blanket salt. Changes of equal magnitude, but opposite in direction, would oceur during the expansion phase. The rates of change of dimensions would vary with local power density, $s$ at no time during the life of a core would the volume fractions corresponding to the maximum contraction or expansion exist throughout the core. At the end of life the graphite at the center of the core would have ienched its maximum volume; graphite in the regions of average power density would be about at its minimum rolume, and graphise in the outer fuel cells would be about halfway into the contraction stage.

Streses arise in the graphite from dimensinil changes due to gradients in temperature and neutron flux. A maximum tensile stres estimated to be about 700 pai would occur at an axial position slightly above the center of the core. In subsequent, more detailed analyses of graphite dements of similar configuration in a one-fluid reactor concept, the maximum stress was calculated to be $500 \mathrm{pai}^{26}$ These stresses are all well below the tensile strength range of 4000 to 5000 psi of graphites being sonsidered for use in MSBR's. ${ }^{4,26}$

No nuclear caliubtions were completed to show how the fuel salt and blanket salt compositions would have to be adjusted to compenate for the change in volume fractions and how the adjustments would affect the performance. However, the power-flattening calculations showed that the power diatribution in the core was quite sensitive to the local volume frestion of blanket sitt. We concluded that a design in which the volume fraction of blanket salt varied so widely was not likely to be satiefactory; thus we looked for an altemative.?

An altemative design for the reactor vesed is shown in Fig. 5.4. The graphite 5 - I tube woermbly for the core of this reactor is shown a Fig. 55. Blanket cells are simply cylindrical tubes of graphite 6\%, in. OD by 5 in. ID, each with a metll tube brazed into the uppar end. The reference desion concept described hese is agein for a reactor with an arerage power demity of 20 $k w / h i t e r$ in the corte. Baxic dimencions of reactors desizned for other power deneities are those in Table 5.1.

The primary difference between this desion and the one just described is that in this case the thanket alt in the core is confined to the mavius isetween fuelcontaining tubes and the outer tube of graphite fueltube ascemblies. The silt in the blanket region is confined to the inside of the blanket cells. To scoomplish this the blankettalt-containing tubes are connected to plenurs in the top of the reactor vesed and dip into a pool of blanket salt in the bottom of the vesed. Hetiur, fills the space between cose anemblie and beiween bbnket asemblies at a presure that is controlled to provide the desired level of blanket alt in the bottom of the reactor vesel.

In this design the changes in axial dimensions are accommodated as before. The graphite tubes are fastened

\footnotetext{
${ }^{26}$ Duniap Scok: and W. P. Eatherly, "Grophile and Xeacas Behavior and Their Infwence on Mowea-Salt Reactor Deimp," Nuct. Appl. Technol. 7(8) (Februmy 1970).

${ }^{27}$ Rewils of more recent vets (Deserober 1968) indicate that

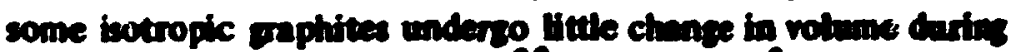
indiations to at least $2.6 \times 10^{22}$ neutroal $/ \mathrm{cm}^{2}$ (E> $50 \mathrm{kov}$ ),

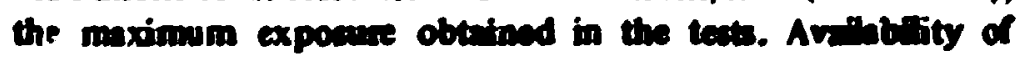
sech materials in the deatred stzes and stapes wousd clinimate the major objection to this decipon.
} 


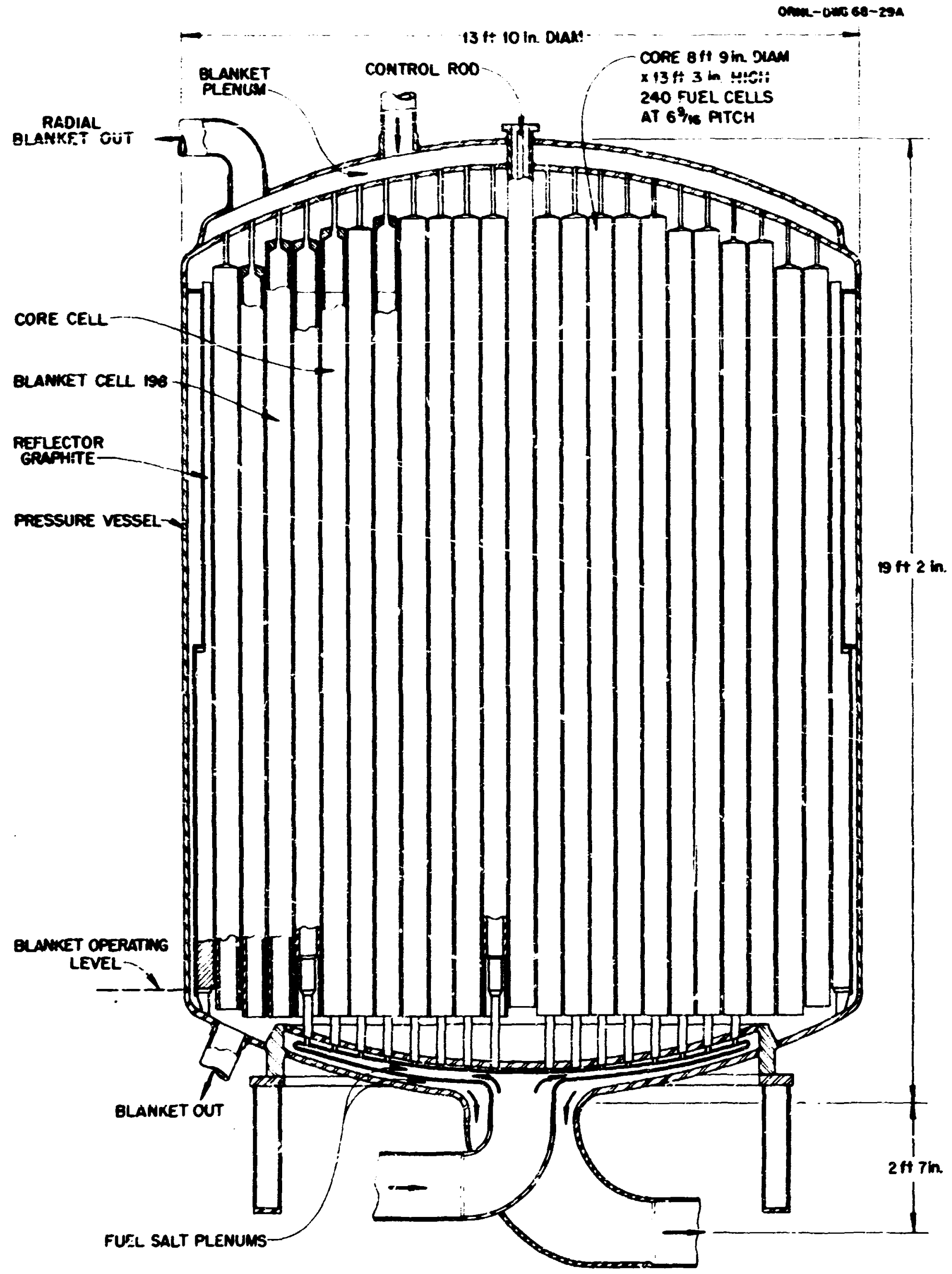

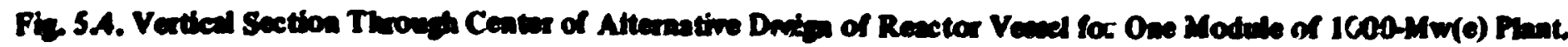




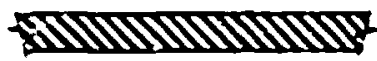

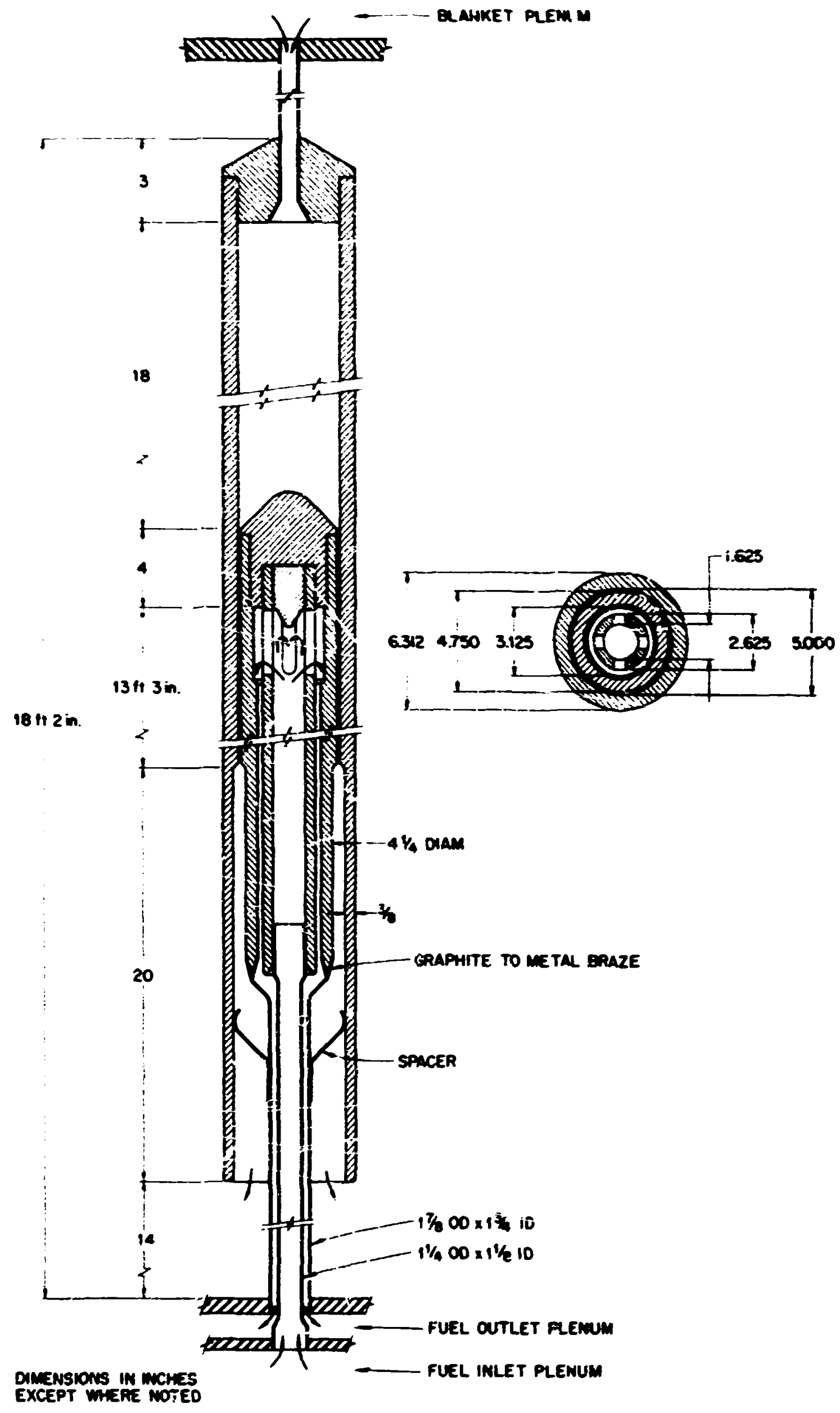

Fie 3.S. Graphite Ped Tube Amerobly for Cose Rogion. 
to a metrl structure at one end only and are free to move axitlly. With blanket salt and fuel salt confined by gaphite tubes in the core region, ndiation-induced changes in the transwerse dimencions of the graphite will produce proportionate changes in volumes of eraphite, bhoket alt, and fuel alt. The rehtive volumes of these meterials would remin abour constent, and the only major changes in frectional volume would occur in the - spaces between dement. Although the nuclear characteriatic sould viry some with time (the amount

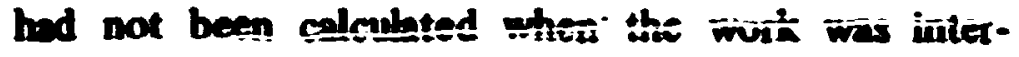
rupied), it would be surprising if there were a large or serious effect.

In this design the fued salt enters the reactor vesed through a plenum in the bottom, flows through the reentrant tubes of the fuel tube assemblies, and leaves through a second plenum in the bottom of the vessed. The blenket sil enters through a plenum in the top of the racel and flows downward thrount the outer annulus of the fuel tube remblies and into the pool of blanket alt in the bottom of the venel. Twothirds of the bunket salt fiow soes out through a pipe from the bottom of the resctor reand to the suction of the blanket alt circulation pump. The discharge from this pump, after pasing through the blanket alt heat exchanger, enters four ejector type jet pumps operating in parallel. The suction side of these jets is comnected to the ndial blanket plenum in the top of the reactor reace. The jets draw blanket alt upward through the maid bunket cells and discharge the combined flow into the plenum that supplies the core elements. This method was choen for sirculating the blanket silt because it seems to overcoms ine problems of distributing the flow between the core clements an's radial blanket elements while asuring that the elements will be kept full of salt.

\subsection{Fuei Salt Primery Heat Exchanger}

Each reactor module has a fuel alt primary heat exchanger in which tine fiscion heat in the fuel salt is transferred to the coolant salt. The exchanger is of the vertical countercurrent shell end-tube type with the fuel alt in the tubes. The impeller and bowt of the fuel selt circulating pump are an integral part of the top heed asembly of the heat exchanger. The pump will be diecuseed separately in Sect. 5.4.

The general configuration of the exchanger is shown in Fig. 5.6, and the principal data are ziven in Table 5.2. Each exchanger is about $6.5 \mathrm{ft}$ in diameter $X 20 \mathrm{ft}$ high and has an effective sursace of $12,230 \mathrm{t}^{2}$. All portions

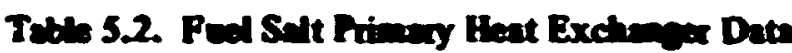

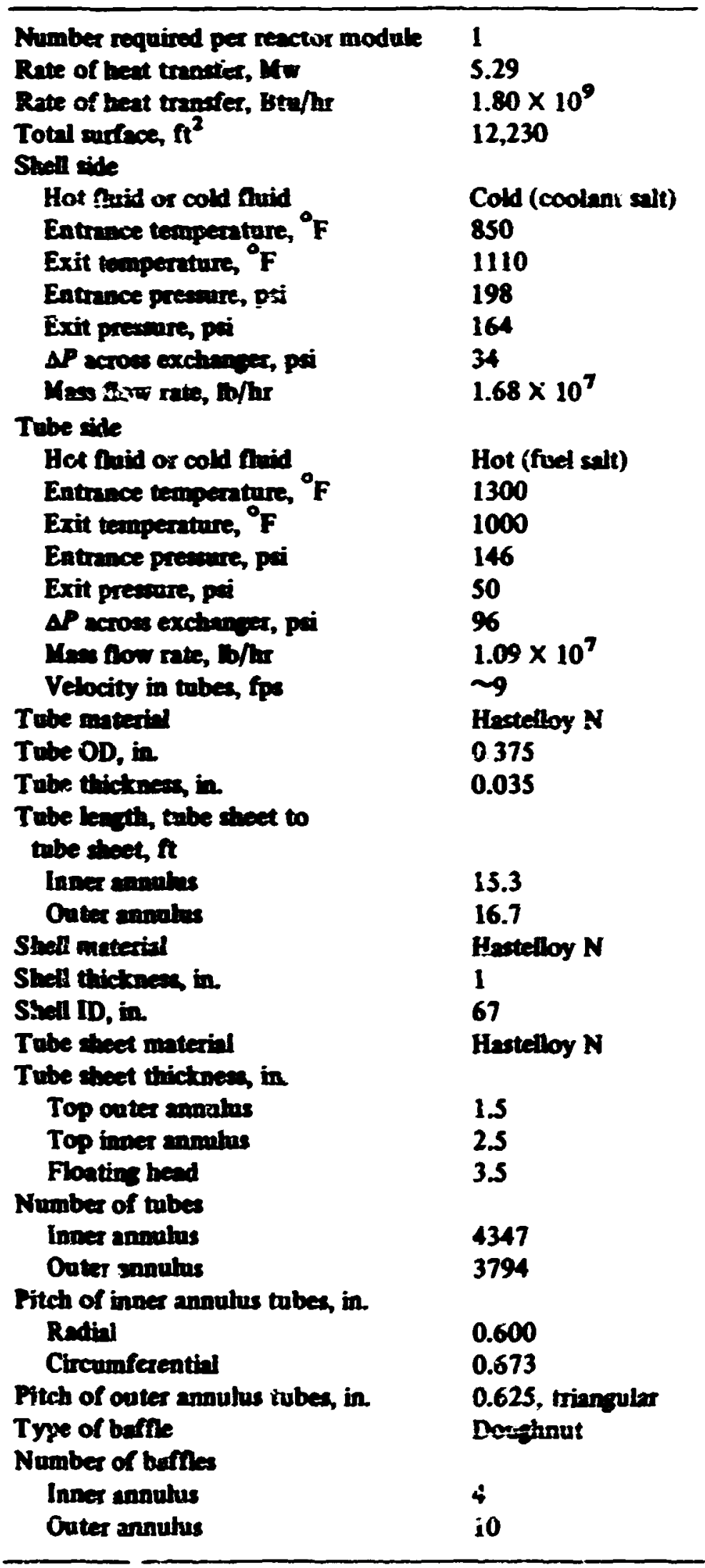

in contact with the fuel and coolant salts are constructed of Hastelioy $\mathbf{N}$. The pump tank, which is about $6 \mathrm{ft}$ in diameter $\times 8 \mathrm{ft}$ high, is mounted directly above the heat exchanger and is part of the punp and heat exchanger aseembly. A 5 in. fill-end-drain line connects the bottom of this tank to the fuel salt drain tanks. 


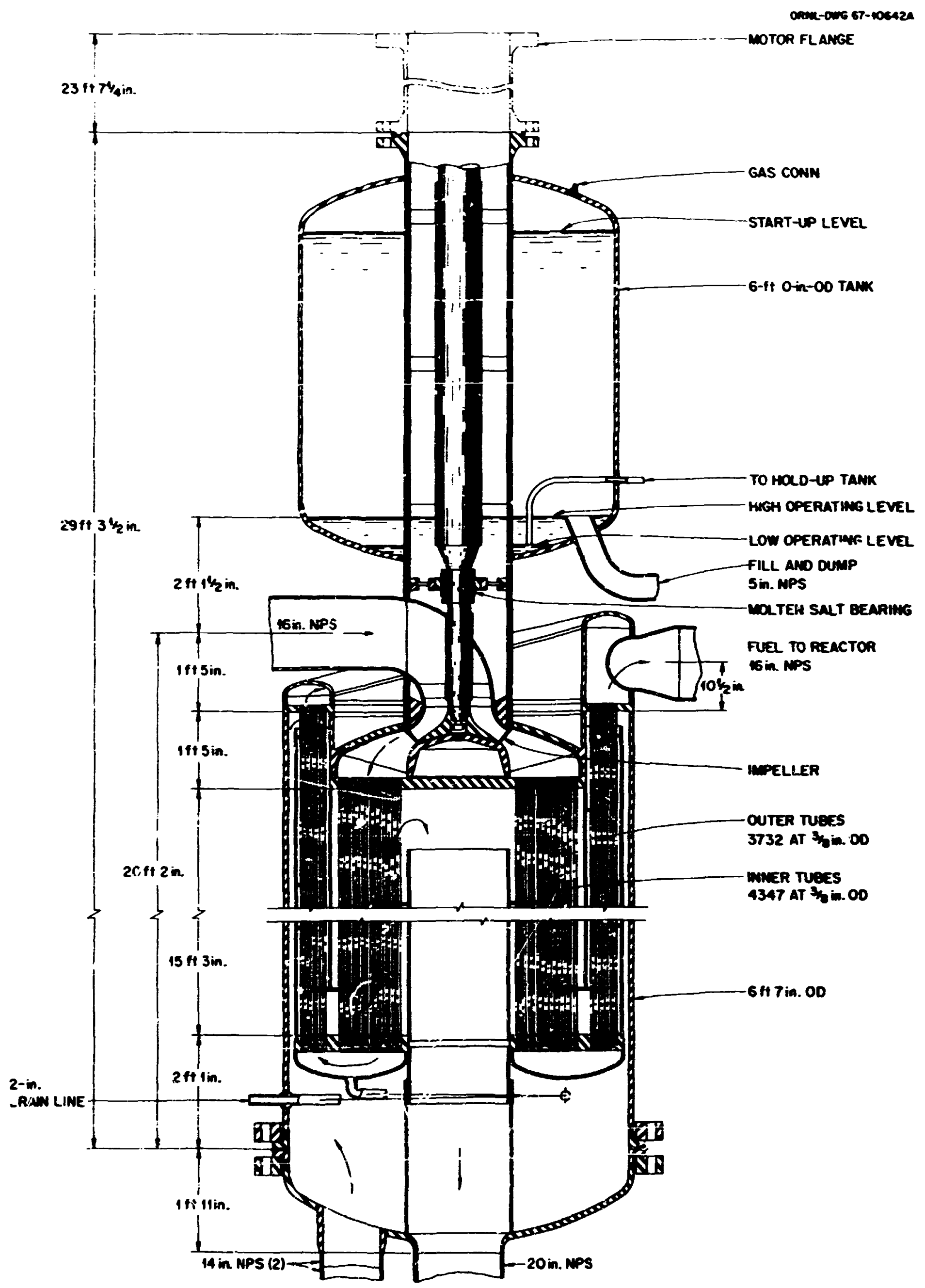

Piz 5.6. Poel Salt Primary Heat Exchanger and Pump Amenibly for 250-MW(e) Reactor Module. 
Fual silt flows from the reactor at $1300^{\circ} \mathrm{F}$ through the 16-in. pipe connected directly to the top of the circubting pump. The pump boosts the pressure from about 9 psi to approximately 146 psi and discharges the salt downward through 4347 bent tubes to the lower tube sheet. The flow direction then reverses, and the salt flows upward through 3794 straight tubes in the outer annulus, or bank, of tubes and leaves the exchanger at about $1000^{\circ} \mathrm{F}$. The tubes in both hanks are $\%$ in. $O D$, and the salt velocity in the tubes averages about $\%$ fps. Using a tube sheet at the bottom, rather than employing U-tubes, provides a plenum for draining the fuel salt from the exchanger. A loop in the 2-in. drain line inside the shell provides the necosary flexibility for thermal expansion and movement of the bottom tube sheet.

The bent tubes in the inner annulus 3 ccommodate the differential expansion between the inner and outer banks of tubes. To simplify the bends, the inner tubes are placed on concentric circles with a constant delta radius and a nearly constant circumferential pitch. A radial spacing of about $0.6 \mathrm{in}$. was selected as being the minimum practical pitch. The tubes in the outer annulus are located on a triangular pitch of 0.625 in. ${ }^{28}$

The $850^{\circ} \mathrm{F}$ conolant salt enters at the bottom through two 14-in. pipes at a pressure of 194 pei and flows upward through the outer annulus to cool the vesed outer wall. It then reverses direction and flows downward over the outer bank of tubes in a counterflow arrangement. At the bottom tube sheet it again reverses direction and flows upward across the inrer bank of nubes. Doughnut-shaped baffles are used in both annuli. The salt then leaves through a 20 in. coolant salt pipe at the center line of the exchanger at about $1111^{\circ} \mathrm{F}$ and 161 psi. Drain ports, not shown in. Fig. 5.6, allow the coolant salt to be drained from the space above the lower tube sheet.

The heat transfer and stress correlations used in conceptual design of the heat exchanger inve been reported by Bettis et ai. ${ }^{28}$ The properties of the fuel and coolant salts and of the Hastelloy $N$ wed in the caicuiations are given in Tables 3.1 and 3.4. Computer codes were r.ritten to optimize the salt-tosalt and silttosteam MSBR heat transfer equipment. Except for some work on the steam generators, howevei, the codes vere not fully operaticnal when this equipment was decigned.

\footnotetext{
${ }^{28}$ GERC Division, Desion Amalysis Section of ORNL, Dexion Study of a Heat Exchange System for One MSBR Concept, ORNLTM-1545 (Sept. 1967).
}

The number of tubes in each of the annular regions was determined on the basis of the desirable pressure drop for the fuel salt flow through the tubes and on the allowable temperature drop across the wall. The heat transfer coefficient in the inner annulus needed to be lowered to minimize the temperature gradient through the wall; the velocity was therefore reduced by using 4347 tubes as compared with 3794 in the outer bank. ${ }^{28}$ The length of the tubes was determined largely on the basis of preliminary calculations which showed that $15 \mathrm{ft}$ would provide about the desired geometry. Baffle spacing in the irger annulus was fixed by the distances required for the unrestrained bends in the tubes and the maximum allowable temperature drop across the walk. The spacing in the outer annulus was selected to give the most efficient use of the shell-side pressure drop. Ten baffles were used in this region. ${ }^{23}$

In this conceptual design, individual tubes cannot be inspected, repaired, or replaced. Retiance is therefore placed on quality control in the manufacture and installation to obtain highly reliable units. Should major difficulties develop in an exchanger, however, it would be nesereary to replace an entire heatexchanger-pump assembly, as discussed in Sect. 5.10. The rotating parts of the pump can be replaced with rehtively little difficulty.

As may be noted in Table 3.1, the thermal cos. ductivity of both the fuel and coolant sits is now known to be substantially less than the values used in design of the heat exchanger presented hese. Use of the newer values would increase somewhat the amount of heat transfer surface and the inventory of salt.

\subsection{Bbaket Salt Primary Heat Exchanger}

Each reactor module has a blanket salt heat exchanger for transferring heal from the blanket salt to the coolant salt. The exchangers ais abouit $4 . j \hat{n}$ in diameter $X 19 \mathrm{ft}$ high crerall and are of the vertical shelland tube type with the blanket alt in the iubes, as shown in Fig. 5.7. Although smaller, the units are very similar to the fuel alt heat exchangers and have the same arrangement of the salt circulating pumps as an integral part of the top head. Hastelloy $\mathrm{N}$ is used for all portions in contact with the salts.

The blanket sait is cooled from about i250 to $1150^{\circ} \mathrm{F}$ in its pasage through the exchanger. The hiow is from the reactor, through the pump, downward through the inner bank of $3 /$, in.OD tubes, to the bottom tube sheet, where the flow turns upward through the outer bank of tubes. Unlike the fuel salt 


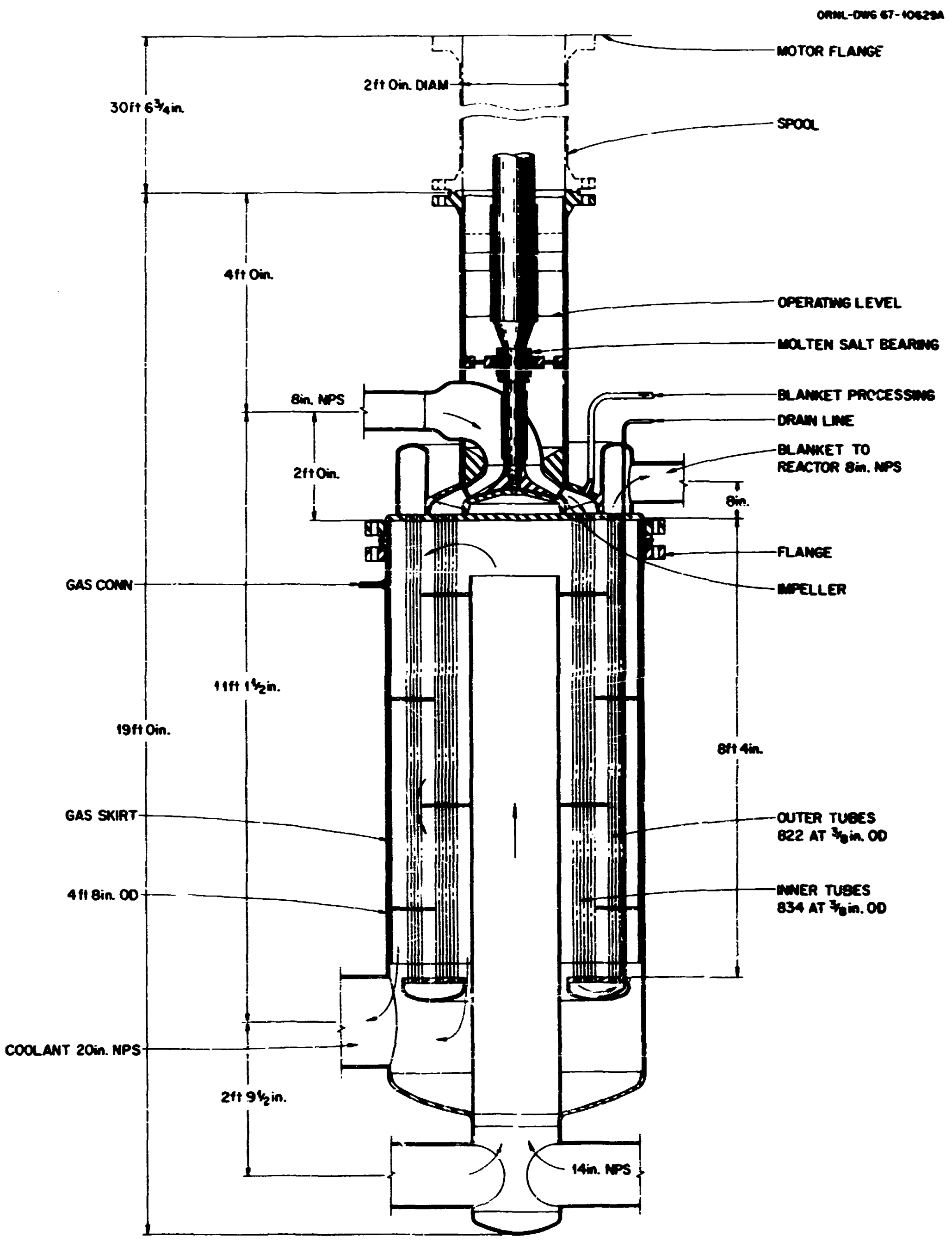

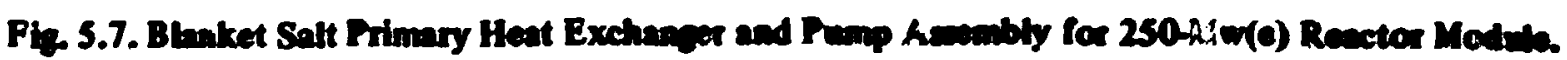


exchanger, stright tubes are ued in both banks. The pertinent data are given in Table 53.

The covbnt sit is circulated in series through the fus ali and blanket wit exchangers. The salt leaves the fuel selt exchanger at about $1111^{\circ} \mathrm{F}$ and is heated to about $1150^{\circ} \mathrm{F}$ in the blanket alt unit, abeorbing about 28 Ywo(t) of heat per reactor module. The coolant makes one pass through the shell side, entering through the 20-in. dinm central column, flowing downusaid between the diskend-doughnut bufies, and exiting through a 20-in.diam side nozale.

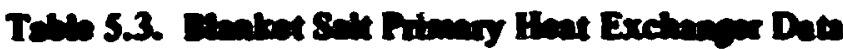

\begin{tabular}{|c|c|}
\hline 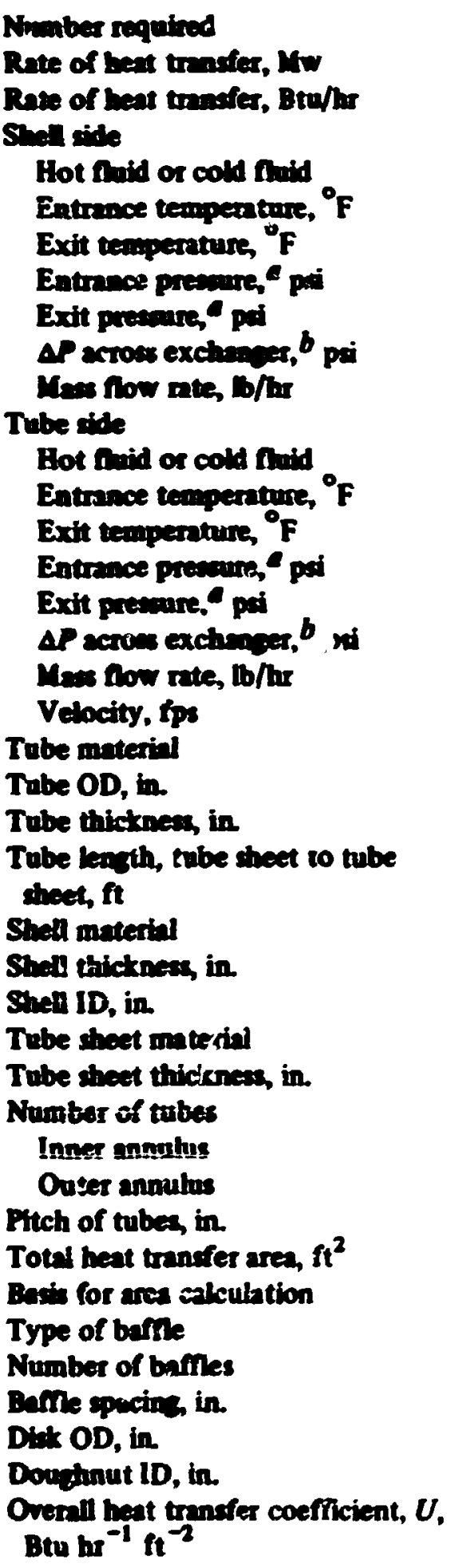 & 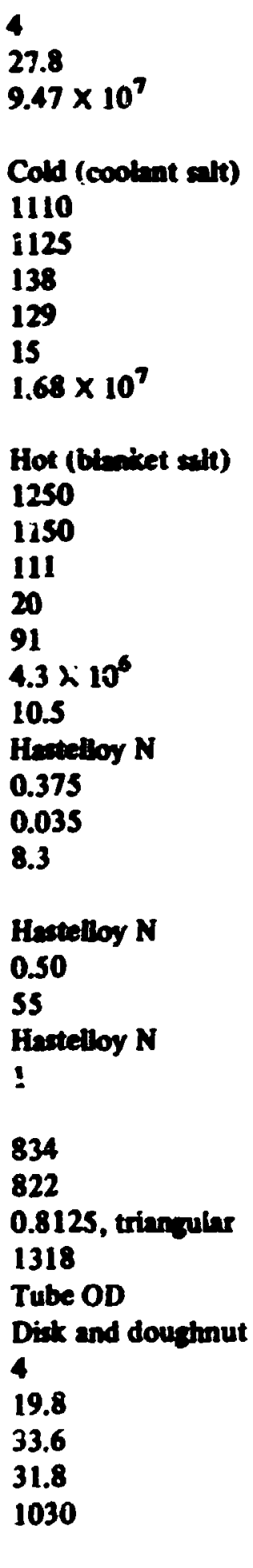 \\
\hline
\end{tabular}

Inchules presure due to grovity head.

bresare bou due to friction only.
Drainge of the blanket salt can be accomplished through a drain line at the battom of the tube sheet, mot shown in Fig. 5.7. A lange pump tank is not required, $s$ in the fuel salt system, since the reactor blanket volume is filled with salt before circulation is started.

Escentislly the same heat transfer relationships were wed for analysis of both the fued and the blanket salt exchangers. The number of tubes per pass in the blanket unit could be eatablished in a straight forward manner, but determimation of the baffle spacing and the tube length that fulfilled both the heat transfer and cressure-drop requirements became involved. The first tep wes to generate dete for the outuide film resionen s a function of the baffle spacing. It was next determined whether the baffle spacing was limited by the thermal stress in the tube wall or by the allowable shell tide pressure drof. Equations were then developed to relate the baffle spacing, the outside film resistance, and the pressure drop, as described in ORNL-TM. $1545 .^{22}$

\subsection{Sak Crectating Puns}

\subsubsection{Gewerl}

The 1000-MT(e) MSBR conceptual dexign employs four fuet salt circulating pumps and four blanket salt pumps, one of each for each of the four reactor modules. The pumps are integral with the rrimary heat exchangers, as illustrated in Fige 5.6 and 5.7. There is also a cooiant salt pump located in each of the four coolant cells. These pumps are somewhat larger but are similar to the fuel and blanket salt pumps.

All the pitmps âre verticai-shait, sumf-type, singlestage centrifugal units and are driven by electric motors. The fuel and blanket salt pumps operate at a constant speed of about $1160 \mathrm{rpm}$, while the coolant salt pumps operate at speeds that are yeriable between atout 300 and $1160 \mathrm{rpm}$. The principai data for the three types of pumps are given in Table 5.4.

As shown in Fig. 4.7, all the pumps have the electric drive motors located in sealed housings st the cperating floor level. This facilitates access to the motors for mintenance, and they can be shielded to protect electric insulation and lubricants from radiation damage. The motor housirg is thus an integral part of the containment system and is subject to the same integrity requirements.

The fuel and blanket salt pumps have long shafts with the impeller and casing located some $30 \mathrm{ft}$ below the 


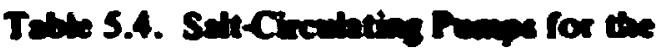
1000-Am(e) asen

\begin{tabular}{|c|c|c|c|}
\hline & Fund & Bbatel & Coolant \\
\hline Number required & 4 & 4 & 4 \\
\hline Dexing tempercture. ${ }^{\circ} \mathrm{F}$ & 1300 & 1300 & 1300 \\
\hline Head, $n$ & 150 & 80 & 150 \\
\hline Speed, rpm & 1160 & 1160 & $300-1160$ \\
\hline Specific spexd, $N_{3}$ & 2630 & 2150 & 3400 \\
\hline Net preitive suction head required, $n$ & 25 & 8 & 32 \\
\hline Impeller inpot power, hp & 990 & 250 & 1440 \\
\hline Distance berween bearing, $n^{b}$ & 29 & 29 & 1.5 \\
\hline Impeller sverisane, $n^{b}$ & 2.5 & 2.5 & $\mathbf{s}$ \\
\hline
\end{tabular}

One poump is required for rach of the four modules in the MSBP.

Eatimated froes pretiminary pump byouts.

drive motor. The upper bearing for the thaft is oiflubricated, but the bearing at the lower end is tubricated by the pesmped salt. In general, a hort-shaf: pump with an werhung impeller and all bearings of the oillubricated type are desirable features since there are fewer development probleme with regard to both the salt-lubricated tearings and the rotor dynamics. Long shafts were used in this MSBR two-fluid design concept, hrwover, because the fuel alt enters and leaves at the bottom of the reactor vessel, placing the pump casing at sbout this same elevation conserves salt inventory, and we preferred to locate the drive motors outside the reac' or cell.

The number of reactor modules selested for the two-fluid MSBR design study was influenced by the size of pump that appeared to be a reasonable extrapolation of the MSRE pump size. One salt pump was assumed per circuit, on the basis of a study made by Grindell and Young, ${ }^{29}$ which found that parallel operation of pumps in which the liquid level in the pump bowl is maintained by a gas overpressure could lead to i.stability problems.

Only preliminary studies were compieted on the conceptual design of the salt pumps. Work had progressed sufficiently to indicate, however, that a careful study of the effect of pump shaft and casing sizes on the rotor dynamics would probably be required. Selection of suitable materials for the salt-lubricated bearing had just begun when the work was terminated.

${ }^{29}$ A. G. Grindell and H. C. Youns, Two Parallel Pumps Installed in a Two-Fluid iwaRegion MSBR - Effect on Liquid Levels of Stopping One Pump During Normal Operation. ORNL-MSR-67-108 (Dec. 22, 1967).

\section{S.4.2 Fued Salt Creainting Pons}

A desion concept for the fuel sult circuinting purup in show in Fie 5.8. The oiflubricated ball bearines and chaft seal at the top are similar to thoce which hove performed satiutisctority in the MSRE. The seal comints of a Graphitar stator bearing apinat a tool sted rotor. Lubricating oi is on one side of the seal, and belium ges is in the shaft annulus on the other side. The gas, in flowing upwaid through a babyrinth seal, prevents movement of lubricating oil rapors downwand and scavenges oil vapors from the system. A downward flow of the purge gas is also provided along the shaft to retard the upward diffusion of alt vapors and fimion product gases.

Some preliminary development was dois on tine salt-hubricated bearing for the lower end of the 34-ftlong pump shaft. One study ${ }^{30}$ indicated that self-ecting hydrodynamic film lubrication was to be preferred over the externally pumped hydrostatic type of filri. The relatively high viscosity of the milten alt provides good load capacity and hydrodynamic niim operation in the laminar regime. A tilting (pivoted) four-ped type of self-acting bearing design was selected as being the most stable. ${ }^{31}$ The bearing would be constructed of Hastelloy $\mathrm{N}$ with a special hard-surfece conting. Four of the conting materials under consideration were: (1) cobalt-

\footnotetext{
${ }^{30}$ Fendibility Study of Rotor-Bearting System Dymamics for a 1250hp Moltemsalt Fuel Pump, MTT.68TR9, Mechanical Technology Incorporated, Apr. 12, 1968.

${ }^{31}$ A. G. Grindell, Summery of study of Feasibitity of Rotor-Bewing Sydem for e I25ahp Molrenselt Fued Pump Conducred by MTI on Suhcartrect No. 2942, ORML internal correipoidence MSR-68-97 (June 27, 1968).
} 


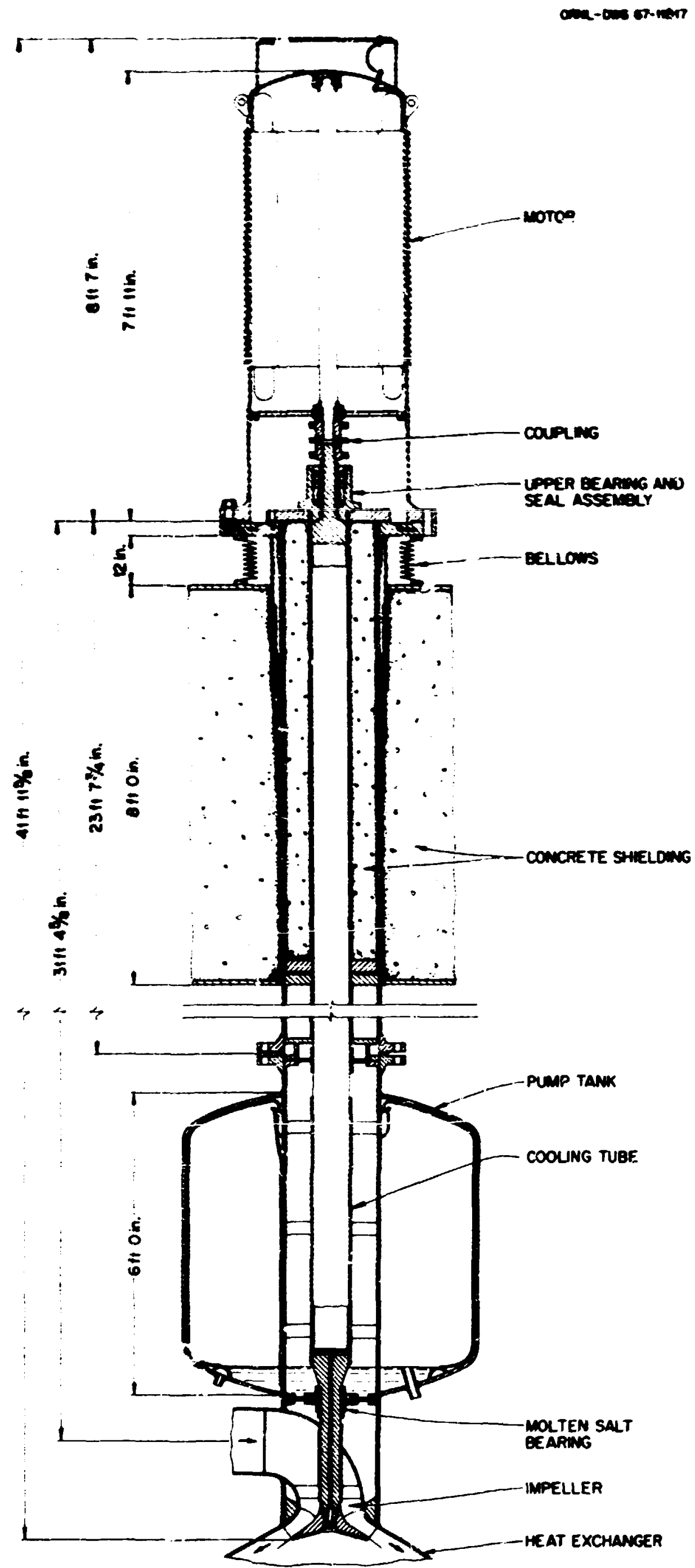

Pie 58. Fod Salt Circulating Punp. 
bonded tungaten carbide, (2) niciel-bcnded tungsten carbide and mixed tungaten-chromium carbides, (3) nick.i-chromium-bonded chromium carbil., and (4) molybienum-bonded tungsten carbide. Speciniens of these hard-sarface contings were obtained but had not been tested.

Becuuse the suel suil pump is a critical item in a moltensalt reactor and the proposed desion of purap was considerably outside the range of our exf rience, some features of the pump were examined in setail. The rotor dynamics were studied under a contract with Yechanical Technolngy Incorporated. ${ }^{30,32}$ Computer studies were made of the conceptual designs to determine flexural and torsional critica! speeds and flexural response to dynamic unbalance. The stability characteristics of the bearing designs were also reviewed. The work, as summarized by Grindell, ${ }^{31}$ covered both 9- and 7.5-in.-OD shaft sizes. The first critical speed for the larger shaft was about $700 \mathrm{rpm}$ and for the smaller shaft about $560 \mathrm{rpm}$, both below the design speed of $1200 \mathrm{rpm}$. The second shaft critical speed was substantialty above $1200 \mathrm{rpm}$ for the larger saft and about 25\% above it for the smaller. Serious study of the problems of acceleration and deceleration of both sizes of shafts through the first critical speed was recommended. It was further recommended that the pump shaft be designed to operate below the first shaft critical speed to reduce the probability of lowspeed, high-amplitude whir and the problems of traversing the critical speed. This would require reduction of the shaft length. lower design operating speeds, or both. These objectives would be difficult to attain without major revisions to the two-fluid MSBR design dascribed in this report.

A prelininary analysis of the undamped torsional critical speed ${ }^{4}$ indicated that the two torsional critical speeds that might affect pump operation could be strongly dependent upon the electromagnetic torsional stiffness of the drive motor. By changing some of the component dimensions, such as increasing the stiffness of the outer pump casing and accounting for inherent damping, it appeared possible that the pump could operate satisfactorily between the first and second critical speeds. If supercritical speed operation were chosen, the study strongly recormmended that a practical means for dynamic balancing of the shaft be dereloped and that a rotor-dynamic evaluation simulator be constructed. This simulator would be a

\footnotetext{
${ }^{32}$ P. W. Curwen, Rotor-Dynamic Feadbility Study of MoltenSalt Pumps for MSBR Power Plants, MTI-67TR48, Mechanical Technology Incorporated, Aug. 6, 1967.
}

full-scale model of the pump rotor dynamic system to evaluate the dynamic response experimentally.

The studies ${ }^{31}$ indicated that approximately 0.025 in. of bow in the middle of a uniformly bowed shaft and approximately $0.019 \mathrm{in}$. of eccentricity between the irines and oute: dianeters of a uniformly eccentric shaft could be accommodated at the shaft critical speed. The values are limited by the bearing eccentricity. $A$ bearing eccentricity value of 0.95 was used in making the calculations. A survey was made of U.S. minufacturers who could fabricate the 34ft pump thafts to the tolerances required. ${ }^{4}$ One was found who expressed confidence that shafts of ine diameters and wall thicknesses of interest couic be produced with a guaranteed straightness from end to end of 0.005 in. and with an OD-ID concentricity of 0.005 in. or better. It was estimated that the cost would be relatively high, however. A study of the effect of the tolerances cn the pump design and costs and on the dynami: balancing faciitities required was in the planning stage.

As shown in Fig. 5.6, a startup tank is provided above the fuel salt primary heat exchanger. The purpose of the tank is to provide submergence for the pump as it is started and the reactor is filled, the pumping capacity of the pump being significantly greater than the transfer rate of the salt from the drain tank. If the pump were stopped, intentionally or otherwise, the fuel salt would flow upward into the bottom of the startup tank and then through the 5-in. overflow pipe to the fuel salt drain tank. Since the tank is not provided with a cooling system the fuel salt is not allowed to fill the tank to more than a few inches in depth except during startup, at which time the overflow pipe is closed.

Some couling of the startup ta $k$ and the pump shaft is provided when the pump is operating. A small stream of fuel salt from the pump discharge passes partway up through the center of the pump shaft and then up through 2 narrow annulus between the shaft and a cooling tube surrounding the shaft. Salt learing the annulis at the top spills back into the tank. Another small stream of salt from the pum:p discharge flows into the double wall of the tank bottom and upward in the xuter double wall to the top of the tank. The flow then turns downward through the annulus formed between the center column of the tank and the pump iasing. Analysis of the shaft and tank wall heating was only partly completed, particularly with regard to removal of afterheat. These and other aspects needed further study.

The pumps are arranged $s 0$ that the rotary element can be replaced by remote maintenance techniques without having to cut any of the salt piping. After the 
motor housing has been set aside, the 2-ft-diam pump cairs can be withdrawn, carrying the upper bearing mi seal, the lower molten-alt-lubricated bearirg, and the impeller with it as a unit assembly. Although not cleaty evioient in Fige 3.6 and 5.8, the inlet salt pipe to the pump is welded to the wall of the veseel surroundins the pump casing, and the $90^{\circ}$ elbow, or inlet flow guide on the inside of the caxing, is an integral part of the rotary element and is withdrawn with it. Maintenance of the drive motor and upper bearing and sal axembly can probably be performed in place through use of a static seal on the shaft to isolate the upper axembly from gaborne fixsion products and other contaminants in the pump tank and fuel salt system.

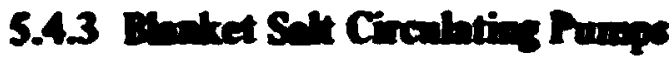

There is little difference between the fued alt and bhaket salt pumps except in the capacity and horsepower requirements, $a$ shown in Table 5.4. The defits are about the ame length, have the ame bearing armonements, and the dynamic rexponse is probably similur.

\subsubsection{Conchat Sall Crealatiog Fures}

The cochnt alt pumps are similar to the fuel and blanket silt pumps, although of larger capacity, s indicated in Table 5.4.

The coolant alt pumps are located near the sop of the steam-generator cells and are of ifse short-sinaft type with an overhuns impeller and. do not need a salthubricated lower bearing. These panuss will be operated at varible speeds ove the rang from about 300 to $1200 \mathrm{rpm}$. Preliminary studirs indicate that to operate below the first critical speed the chaft would have to be 8 in. or more in diampier.

A double volute pump casing was selected for the coolant salt mump in order to reduce the radial londs on the impeller, particularly at off-design conditions. This arrangement also reduces the diameter of the flexible connection from the volute to the pump tank nozzle. The coolant alt system would be provided with a tank to act as a surge volume and to accommodaie thermal expansion of the coolant salt.

\subsection{0fi.6. Syztem}

Fision product gases must be continuoudy removed frum the circulating fuel salt to prevent ${ }^{135} \mathrm{Xe}$ from absorbing $s 0$ many neutrons that the breeding gain will be significantly lowered. The neutron loses can be greatly reduced by continuousty sparging the salt with helium which, in its subsequent removal, carries awny the xenon and krypton. Both of these gases are only dightly soluole in the salt. Xenon that diffuses into the pores of the reactor core graphite must also be considered. As discussed in Sect. 3.4, the amount of xenon that diffuses depends on the ratio of the surface area of helium bubbles in the circulating salt to the surface area of graphite in the core, the rate of injection and removal of bubbles, the coefficients for transfer of xenon to both bubble and graphite surfaces, and the permeability of the graphite to xenon. Assuming a processing-cycle time of sbout $1 \mathrm{~min}$ and a graphite conting efrectiveness which reduces the peimeability to xenow as effectively as the preliminary teas indicate, about $0.5 \mathrm{vol} \%$ of gs bubbles in the fuel salt in the core will keep the ${ }^{135} \mathrm{Xe}$ poirsn fraction below $0.5 \%$.

The major features of the offyes system were established, but only a few of the details were exanined. The helium is injected into the circulating fuel silt through a bubjole generator at a rate of about 2.5 sefin per reactist module. The bubble generator is a Venturilike section of pipe capabie of producing bubbles with diameters in the range of 15 to 20 mik. The bubbles recirculate vith the fuel sil, making, on the average, about ten pases through the primary system before being removed by means of a centrifugal separator. Swirl vanes at the entrance to the separator induce rotational flow in the liquid that causes entrined ga bubbles to collect in an axial vortex from which the gas is withdrawn. Vanes at the exit of the separator remove the swirl.

The gas separator and bubble generator can be installed in a bypass line around the fuel salt circulating pump or in the main circulating system In the former location the bypass flow would have to be about $10 \%$ of the total flow, the separator efficiency should be near $100 \%$, and a large presaure drop would be available to operate the separator. If installed in the main stream, the pressure drop that could be allutted to operation of the separator would be much less, but the bubble removal efficiency would only hove to be about $10 \%$.

Effluent from the gas separator, composed of helium, krypton, xenon, a "sinoke" of noble metal fixion products, and as much as $50 \mathrm{rol} \%$ of salt, is delivered to an entrainment separator. There it is joined by a second stream of about 0.5 scim of gas that is used to purge the fuel salt pump tank. The salt and gas are separated, the alt is returned to the auction of the fuel alt circulating pump, and the gen with its burden of fistion products and a amall amount of salt mist is discharged to a gas procexing system that retains the 
xenon for about $48 \mathrm{hr}$ - time enough for most of the $135 \mathrm{Xe}$ to decay - before it is recycled to the reactor.

Whether four, two, or one gas processing system would be provided for a $1000-M m$ (e) mudular plant had not beer. vixided, but for the purpuses of this discussion we will assume thit the gases from the four reactor modules are combined and handled by one processing system. The first part of the gas processing system is a decay tank where the $12 \mathrm{scfm}$ of gas is held for about 1 hr and most of the short-lived fission products release their heat. In this tank the solid daughters of the radioactive gases, the noble natui particles, and the salt mist are separated from tis gases by a particle trapping system and are sent to the full reprocessing plant. Heat is released in the decay tank and particie tap at a rate of about $18 \mathrm{Mw}$, and care must be taken to provide adequate cooling.

Gas leaving the Ithr decay tank passes into beds of cinarcoal that are designed 'o retain xenon for about 47 hr. These traps are water-cooled, and the heat load is about $3.2 \mathrm{Mw}$. On leaving the charcoal beds, about 10 scfm of gas pases through a water monitor and trap to a compressor that recirculates the gas to the bubble generators in the reactor primary systerse. The remaining $\mathbf{2 s c f m}$ is procesved further to remove the knjpton: xenon, and tritium, and the helium is recycled to the pump tanks and to other parts of the reactor that require clean gas.

\subsection{Drin Tark}

\subsubsection{Cenerd}

Drain tanks are provided for the fuel, blanket, and coolant salts so that they may be sefely stored and icolated when mintenance or reactor replacement is required. Draining of the fuel salt is also a sutdown measure in that the reactor quickly drains and becomes subcritical if the fuel salt pump stops. In any situation where heat generated in the primary system could not be effectiveh removed via the coolant salt circuit, it would be necessary to quickly drain the fuel salt into the storage tank where an independent heat removal system is provided. ${ }^{33}$

The volumes of salt to be stored were not firmly established because of dependence on only tentative plant layouts, but a rough estimate of the total storage requirements is 1200 to $1400 \mathrm{ft}^{3}$ of fuel $201 \mathrm{t}, 2000$ to

\footnotetext{
${ }^{33}$ The reference litenture someimes refers to the storese tanks as "dump tanks" because of the quick-drain feature in the tworluid MSBR.
}

$2500 \mathrm{ft}^{3}$ of blanket salt a.d 800 to $1000 \mathrm{ft}^{3}$ of coclant alt.

Two fuel sait tanks, four blanket salt tanks, and four coolant salt tanks are provided for each reactor module. These tanks are installed in a drain tank cell that is shared by adjzcent reactor modules, as shown in Fig. 4.6. In addition, a flush salt tank (ste Sect. 5.6.5) located in the same cell serves both reactor modules. The drain tank cells are heated to maintain the salts above the liquidus temperatures.

The fuel alt drain tank represents more of a design problem than the other salt storage vessels and will be discussed in greater detail. It may be noted that the fuel salt drain tanks have many of the design requirements of the reastor vessel itself in that the tanks must be fabricated of Hastelloj iv, are designed for essentially the same pressures and temperatures, and must meet the same requirenents for leak-tightness and integrity. In addition, each of the eight tanks must have sufficient heat transfer surface for removing at least $12 \mathrm{MW}(t)$ of heat from the dained fuel alt. Conceptual desizin for the drain tanks are presented here. Many detaits remained to be examined.

\subsection{Fad Selt Dria Tarts}

The two fuel salt irain tasks are connected tofottei at the bottom of a sit line provided with a freeze valve, a indicated on the flowsheet, Fig. 45. The pump orenfow line enters the top of one tank, and the system drain line enters the bottom of the other. By uxing two tanks, presarization can be uned tc. retum the salt to the circulating system without need for a valve in the pump overifow line. The volume of the heels laft in the tank is also reduced.

Each of the fuel salt drain tanks is about $5 \mathrm{ft}$ in diameter $X 25 \mathrm{ft}$ high, as shown in Fig. 5.9. Pertinent data are given in Table 5.5. The salt-contrining portion is about $19 \mathrm{ft} 6 \mathrm{in}$. high and has $3 / 4$-in.thick Hastelloy $N$ walls. The 1-in.-thick inverted dished bottom head is deaigned to minimize the inventory of fuel salt in the tank heel. The inside of the tank has a $1 / 4$-in.-thick liner, or skirt, standing off from the wall about $1 / 6$ in., which acts as a downcomer on filling the tank and as a river when gas presurization is used to empty it. It may be noted in Fig. 5.9 that the river skirt communicates with the tank only at the bottom of the heel. A drain line is provided at the low point.

Steam at 500 to 600 psia and about $650^{\circ} \mathrm{F}$ is introduced as a coolant at the top of the drain tank. The steam enters through an 18 -in.-diam reinforced rozzle in the $1 \frac{1}{2}$-in.-thick top head. The steam then 


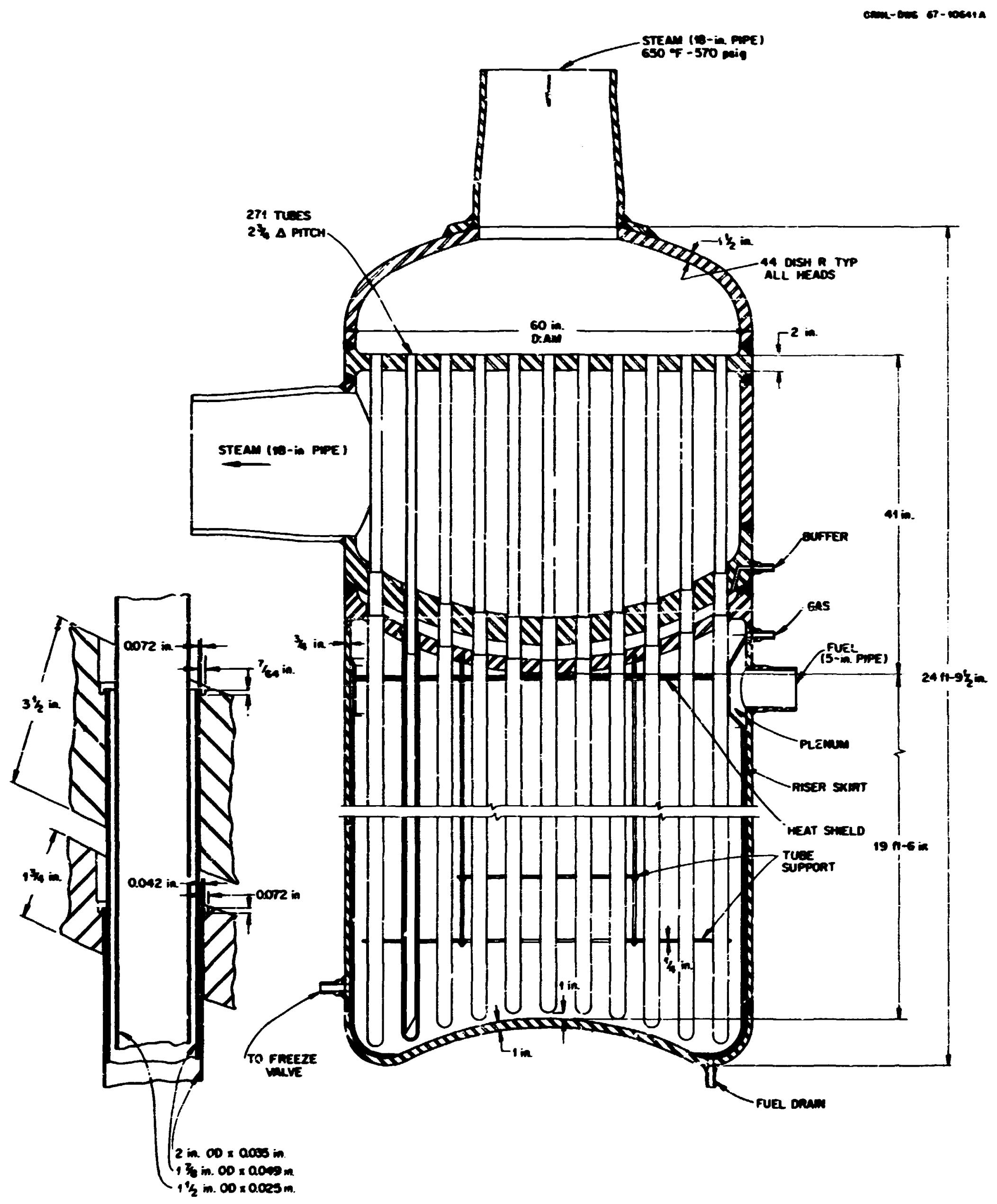

Fiz 5.9. Fud Salt Dain Tak for Twofind MGBR. 
circulates through 271 cooling thimbles which are immersed in the fuel salt. The steam flows downward through $1 \frac{11}{2}$-in.OD $\times 0.025$-in.-wall-thickness tubes which are inside a $17 \%$-in. OD $\times$ 0.049-in.-wall-thickness tube to form an annular pasenge through which the steam returns upward to the steam chest at the top of the tank.

Each thimble is encased in a 2-in.-OD $\times 0.035$-in.wall-thickness thimble which provides the requisite double containment between the fuel salt and the steam. The 0.027-in. annular space between the inner and cuter thimbles is filled with a stagnarit salt, probably of about the same composition as the coolant salt, which acts as a heat transfer medium. While this buffer space between the thimbles retards the heat transfer somewhat, it has the desirable effect of limiting the thermal shock on the steam thimbles after a drain and also of preventing excessive thermal gradients.

Table 5.5. Puel Solt Drie Tank Date

\begin{tabular}{|c|c|c|c|}
\hline 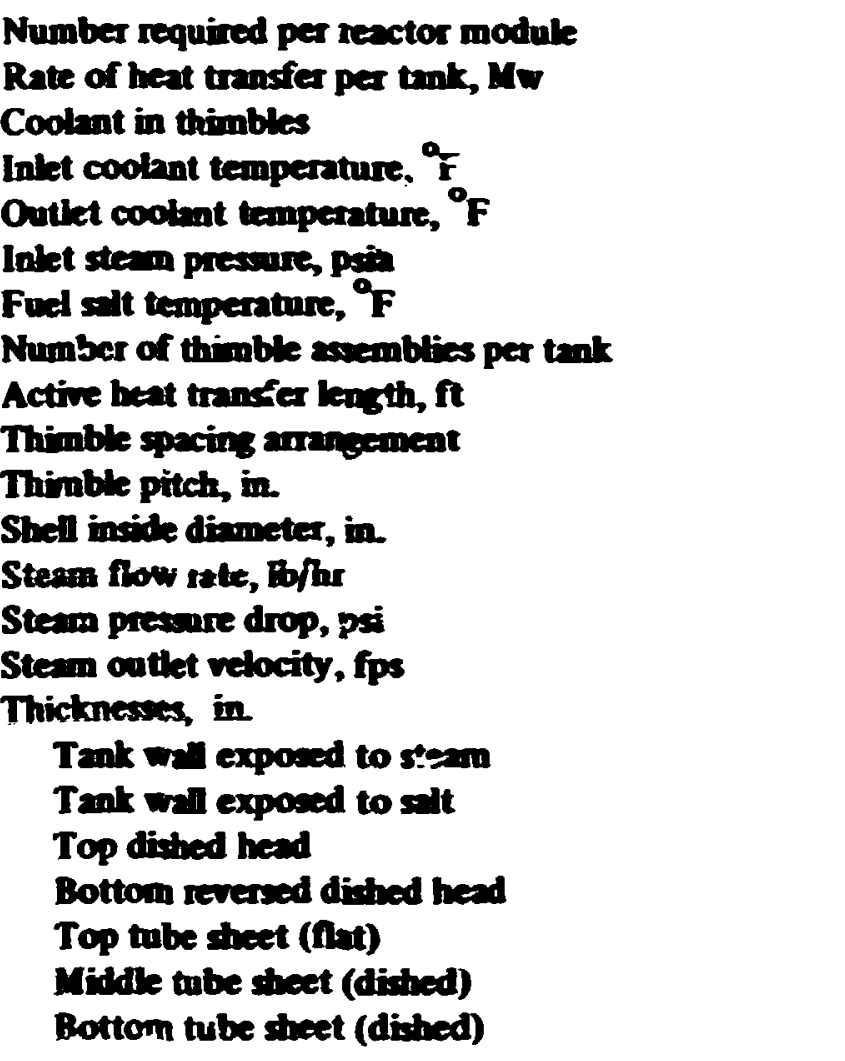 & & \multicolumn{2}{|c|}{$\begin{array}{l}2 \\
12 \\
\text { Stean } \\
650 \\
1000 \\
540 \\
1150 \\
271 \\
19 K_{2} \\
4 \\
27 \\
60 \\
211,000 \\
7 \\
72\end{array}$} \\
\hline Thimble tubes, in. & D & & $\mathbf{O D}$ \\
\hline $\begin{array}{l}\text { Onter wall } \\
\text { Inner wall } \\
\text { Coolant supply tube }\end{array}$ & $\begin{array}{l}1.930 \\
1.777 \\
1.450\end{array}$ & & $\begin{array}{l}2.000 \\
1.875 \\
1.500\end{array}$ \\
\hline 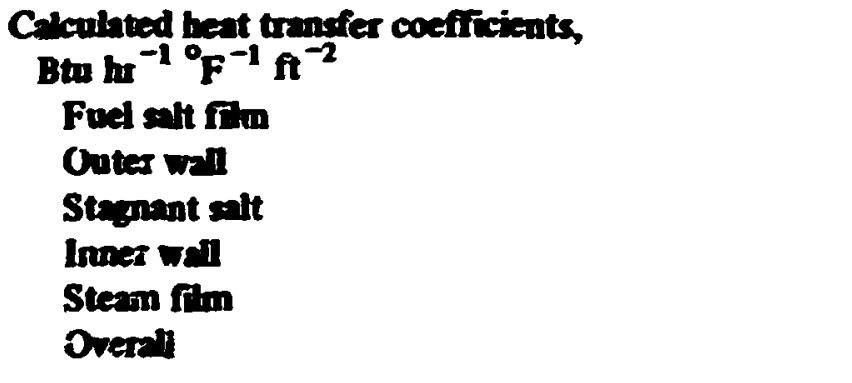 & & $\begin{array}{l}130 \\
4000 \\
184 \\
2180 \\
189 \\
52.3\end{array}$ & \\
\hline 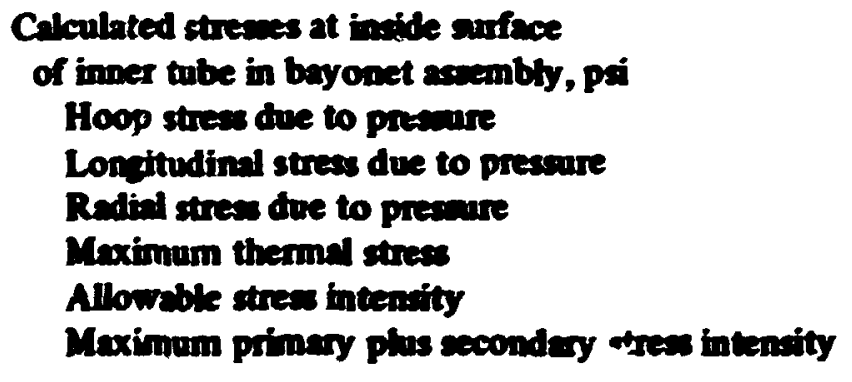 & & $\begin{array}{l}10,400 \\
5200 \\
-540 \\
2760 \\
17,000 \\
13,700\end{array}$ & \\
\hline Approximate :losere volume per tond, $f^{3}$ & & 200 & \\
\hline
\end{tabular}




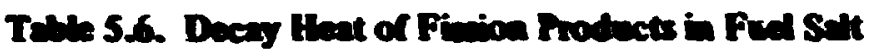

\begin{tabular}{|c|c|c|c|}
\hline \multirow{2}{*}{$\begin{array}{c}\text { Time After } \\
\text { Drain }\end{array}$} & \multicolumn{2}{|c|}{ Watts pee $\mathrm{f}^{3}$ of Fued } & \multirow{2}{*}{$\begin{array}{l}\text { Difierence in Hea } \\
\text { Cenerntion (\%) }\end{array}$} \\
\hline & $\begin{array}{l}\text { Gross Amounts of } \\
\text { Firsion Products }\end{array}$ & $\begin{array}{l}\text { Kr and Xe Sparged } \\
\text { on 30-sec Cycte }\end{array}$ & \\
\hline & $\times 10^{4}$ & $\times 10^{4}$ & \\
\hline 0 & 16.4 & 14.4 & 24.2 \\
\hline $1 \min$ & 6.2 & 4.7 & 14.2 \\
\hline$S \min$ & 4.8 & 3.5 & 27.1 \\
\hline $10 \mathrm{~min}$ & $\therefore 2$ & 3.0 & 28.6 \\
\hline $30 \mathrm{~min}$ & 3.1 & 2.2 & 29.0 \\
\hline $1 \mathrm{hr}$ & 2.5 & 1.8 & 28.0 \\
\hline $2 \mathrm{hr}$ & 1.9 & 1.45 & 23.7 \\
\hline $5 \mathrm{ht}$ & 1.35 & 1.08 & 20.0 \\
\hline 1 day & 0.699 & 0.656 & 6.1 \\
\hline
\end{tabular}

The exit steam chest is formed by the uppermost 2-in.thick tube sheet and an inverted dished head about $31 / 2$ in. 'jick. A third $1 \frac{1}{4}$-in.-thick tube sheet forms the buffer space for the stagnant salt. A 1/2-in.thick heat shield is suspended beneath the lower tuibe sheet to protect it from thermal gradients and stresses when the hot fuel solt enters the drain tank after a sudden drain. Thimble support plates $1 / 4$ in. thick are suspencied from the lower tube sheet to minimize vibrations induced in the thimbles by the flowing steam and to maintain the spacing.

The two fuel silt tanks which serve a reactor module are located in the deeper end of the drain tank cell, as shown in Fis. 4.11, with one of the tanks at a higher elevation than the other. The upper tank is the one depicted in Fiz. 5.9 and has a 5-in. alt drain line nozzle at the top connected to the overflow from the fuel salt circulating purup boud. The drain tank at the lower level does not require the S-in. nozzle but is filled and emptied through the 1 -in. bottom drain connection. This 1-in. line is connected through a frseze valve to the bottom of the fuel sit primary heat exchanger.

The liquidus temperature of the fuel salt is about $842^{\circ} \mathrm{F}$. Although there is little danger of the fuel wit freecing once the reactor has operated at power, nevertheless the cooling steam temperature cannot be operated tos far below the alt temperature if the Felinood of local freezing of the salt is to be avoided. Of greater concern are the temperature gradients in the tube walls and tube sheets if the differences in temperature between the silt and the steam are too greal. The cooling steam has been asaumed to be admitted at sbout $650^{\circ} \mathrm{F}$. The source of the $650^{\circ} \mathrm{F}$ steam has not been fully studied, but presumably it could be taken from the exit of the reheat steam preheaters in the turbine plant.
The cooling steam in the drain tanks could be heated to as high as about $1000^{\circ} \mathrm{F}$ in the thimbles by the conditions existing immediately after a drain following kng-term operation at full reactor power. The steam would be condensed in the turbine condensers, and the condensate would be returned to the feedwater system. In this two-fluid MSBR concepi other reactor modules could continue to operate even though one or more of the reactors had been drained. In the event that all the reactors were drained, cooling steam would be supplied by the auxiliary boiler which is used to supply initial warmup stearn for the plant.

The heat generation in the fuel salt after a drain from the reactor was investigated by Carter. ${ }^{34}$ He considered both the equilibrium concentrations of fission products with no sparging of krypton and xenon during reactor operation and the concentrations of fiesion products if these gases were sparged from the reactor system on a 30-sec cycle. The results are shown in Table 5.6.

The heat transfer to be expected in the drain tank was studied by Pickel. ${ }^{35}$ The results are summarized in Table 5.5. Preliminary investigation of the stresces indicated that they were within allowable limits. A complete analysis of the vessel was not made, hotvever. Use of air rather than steam as a coolant was also briefly investigated.

\subsubsection{Barket Salt Drin Taks}

A total of 16 drain tanks was selected to store the extimated 2000 to $2500 \mathrm{ft}^{3}$ of blanket salt. This provides four blanket salt tanks per module.

\footnotetext{
34W. L. Carter, Heat Genenation in MSBR Fued After Remond from the Reactor, ORMLABR-67-57 (Jaly 31, 1967).

${ }^{35}$ T. W. Pictel, Heat Remonal from IMSBR) Pued Dump Take, ORNLASR-67-72 (Sept. 6, 1967 ).
} 
The amount of heat that could be generated in the blanket salt after an emergency drain to the storage tanks was not calculated. but the preliminary assumption was that no cooling thimbles would be needed in the tanks. If required, a steam cooling system similar to that used in the fuel salt tanks would be proviced.

\subsubsection{Cooknt Salt Drin Tanks}

The layouts of soolant salt piping were not sufficiently de:ailed 'o estimate the quantity of coolant salt in the systerr.s. A rough estimate of the storage capacity required was 800 to $1000 \mathrm{ft}^{3}$, but this is likely to be low. Four coolant salt tanks were provided per reactor module.

The coolant salt tanks would not require cooling systems.

\subsubsection{Flush Salt Drain Tanks}

A flush salt is provided for removal of resiaual fuel salt from the circulating system in order to lower the radioactivity level during maintenance and to assure more complete recovery of valuable constituents. On startup, the flush sait would be circulated in the systems to sweep out foreign materials, moisture, etc., before introducing the enriched salts. The composition of the flush salt would be very similar to the ${ }^{7} \mathrm{LiF}$ $\mathrm{BeF}_{2}$ fuel carrier salt. The volumes required and the tank sizes were not established.

\subsection{Steam Geserators}

The 1000-Mw(e) MSBR power station described in this report requires about $10 \times 10^{6} \mathrm{lb} / \mathrm{hr}$ of total steam generation. This is divided between 16 steam generators, or 4 steam generators per inodule. The number of units was selected on the basis that the high ( 3800 psia) design pressure on thi= steam side made larger capacity units appear to have disproportionately thick heads and tube sheets. Mainterance aspects also favored selection of a multiplicity of units since the generators as designed are not easily repaired and replacement of entire units could be required.

The coolant salt flow is proportioned between the steam generators and the reheaters as neceseary to obtain a $1000^{\circ} \mathrm{F}$ outlet steam temperature from each. Aboit $87 \%$ of the total coolant salt flow is required for the steam generators. The coolant salt is cooled from about 1150 to $850^{\circ} \mathrm{F}$ in the units. Flow control is accomplished cither by a regulating valve in the alt line, as indicated in Fig. 4.5, or by use of two variable-speed coolant salt circulating pumps per module. Load regulation and partial-loac operation received only superficial investigation.

As shown in Fig. 5.10 the steam generator is a vertical shell-and-tube unit with counterflow between the oncethrough passage of the supercritial pressure water in the tubes and the coslant salt in the baffled shell space. The generator has a U-shaped cylindrical shell about 18 in. in diameter with each leg standing about $34 \mathrm{ft}$ high, including the spherical head. A baffe on the shell side of each tube sheet provides a stagrant hyer to help reduce the stresses in the sheet due to temperatur: gradients. The coolant salt can be drained from the shell, but the water woukl have to be removed from the tuhes by evaporation, by gas pressurization, or by flushing. (Drainability of the water was considered desirable but not mandatory.) Both the tubes and shell are fabricated of Hastelloy $\mathbf{N}$ in this design concept, but less-expensive materials might be acceptable.

The principal data for the steam generators are listed in Tabie 5.7. The design variables to be determined were the nuiriber of iubes, the rube pitch, length of tubes, thickness of tube wall, thickness of tube sheet, baffle size and spacing, dinmeter of shell, thickness of shell, and thickness and siape of the heads. Because of the marked changes in the physical properties of water as its temperature is increased above the critical point at supercritical pressures, the temperature driving force and the heat transfer coefficient varied markedly along the length of the tubes. These conditions required that the beat transfer and pressure drop be calculated for increments of length. An iterntive procedure was programmed for the CDC 1604 cornputer, as described in ORNL-TM-1545.28 Based on the coolant salt properties given in Table 3.1, the optimum design was calculated to have a long slim shell and relatively wide baffle spacing as shown in Fiz 5.10. Subsequently the thermal conductivity of the coolant salt was found to be substantially less than had been used in the calculations. Use of the lower thermal conductivity could be expected to increase the number and length of tubes and to increase the shell diameter by a small amount.

\subsection{Steam Rehenters}

A single-reheat power cycle was selected for the MSBR plant althouph additional stages of reheat could be provided should this prove to be economically dexirable. The stean conditions used in this study, and shown in Fig. 4.12, are that the steam from the high-prescure turbine exhaust is at $552^{\circ} \mathrm{F}$, a tempereture judged to be too low to be admitted directly into 

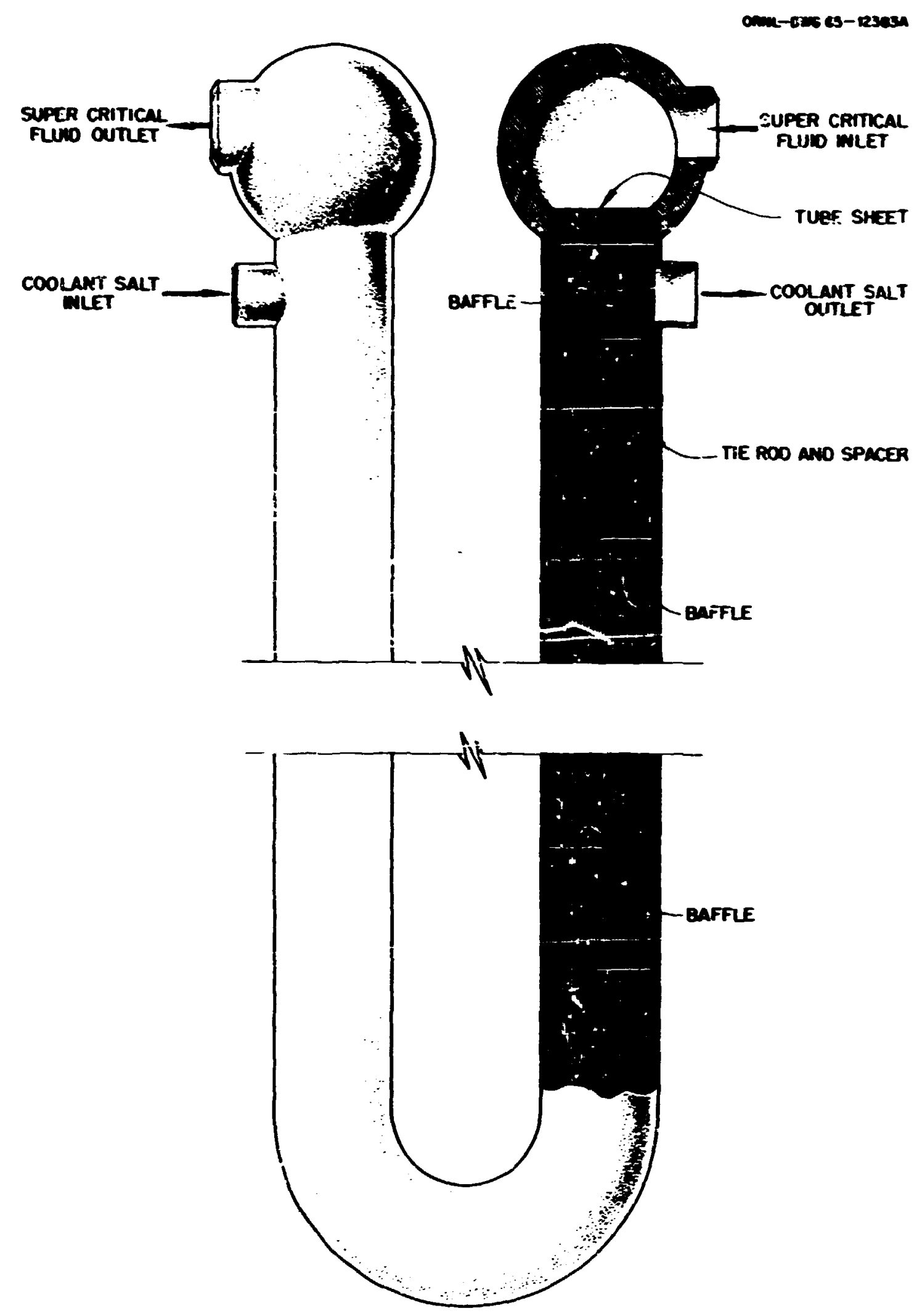

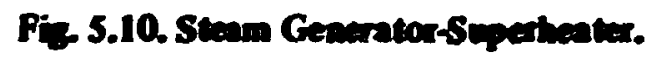

the rehesters without the likelihood of local freezing of the coolant salt. The steam is therefore preheated by use of prime steam. (See Sect. 5.9 for a description of the preheaters.) The preheated steam, at about $650^{\circ} \mathrm{F}$ and 570 paia, is then reheated to $1000^{\circ} \mathrm{F}$ in the steam reheaters. About 13\% of the total reactor heat output is uned for steam reheating in a total of eight units, or two per module. Selection of the number of units was brgety intuitive because optimization studies had not commenced.
The reheater units are counterflow, vertical, shalland-tube exchangers with straight tubes containing the steam and coolant salt flowing through the disk and doughnut baffes on the shell side. Tubes and shell are constructed of Hastelloy N. The principal data are listed in Table 5.8, and the unit is pictured in Fig. 5.11.

The methods used in the calculations of the heat transfer and atresses are much the same as those used for the steam generator and are described in detail in ORNL-TM-1545. ${ }^{28}$ 
Table 5.7. Stene Gewerator Date

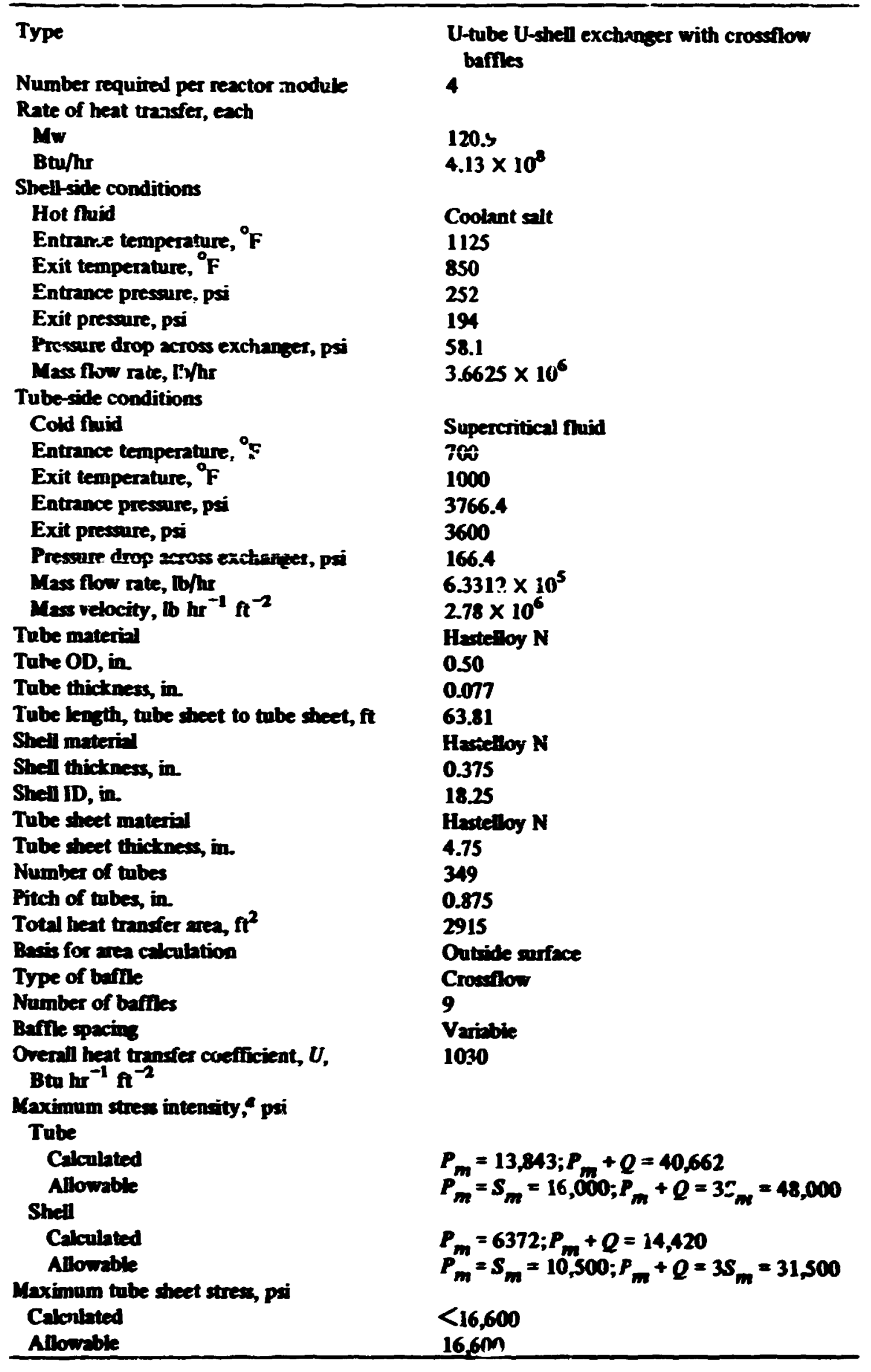

The symbols are the nme as those used in Sect. III of the ASME Boiler and Fresure Verat Code. 


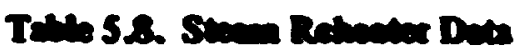

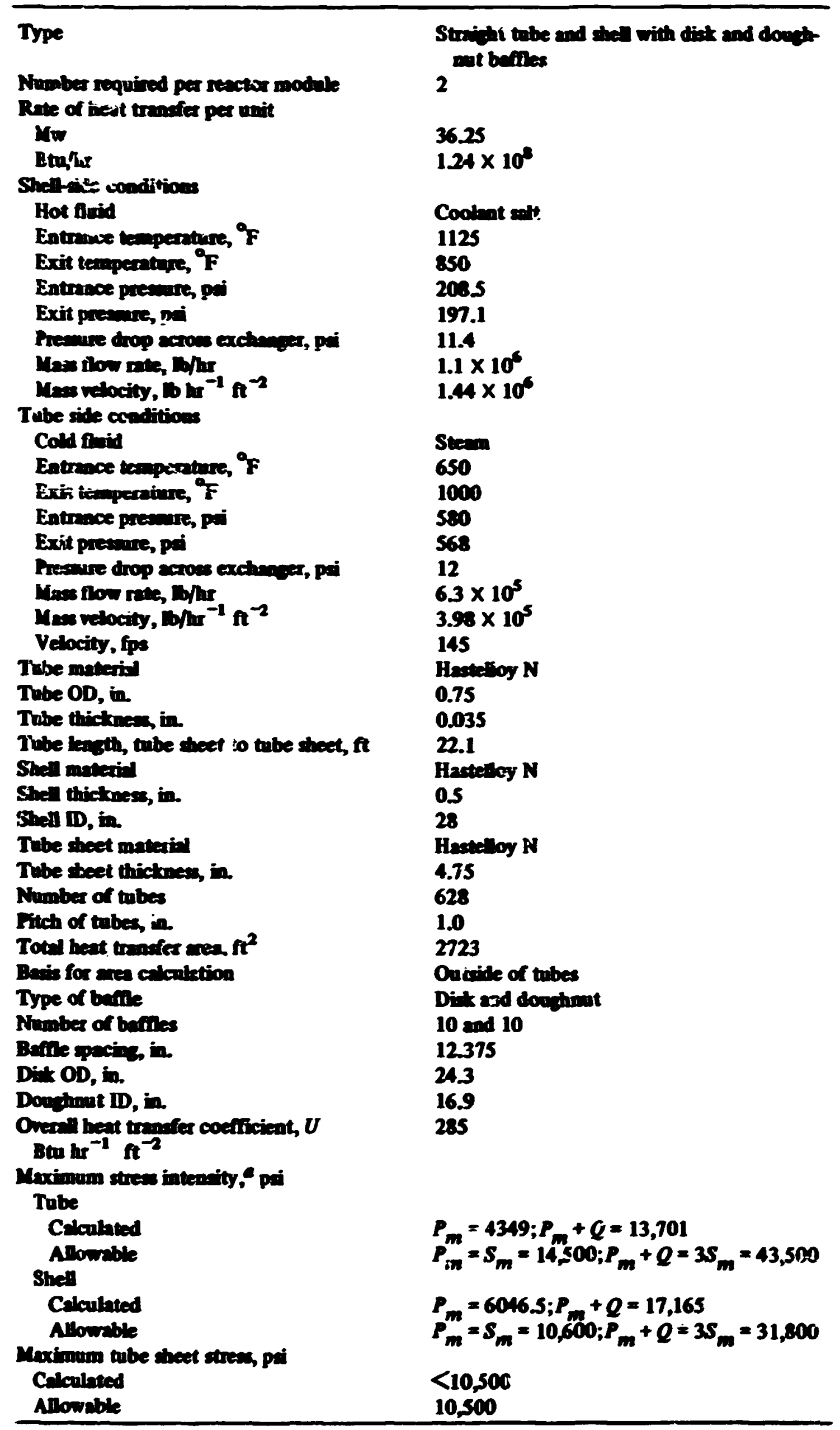

The symbols are the sure as thowe used in Sect. II of the ASME Boiler and Freware Ver. at Code. 


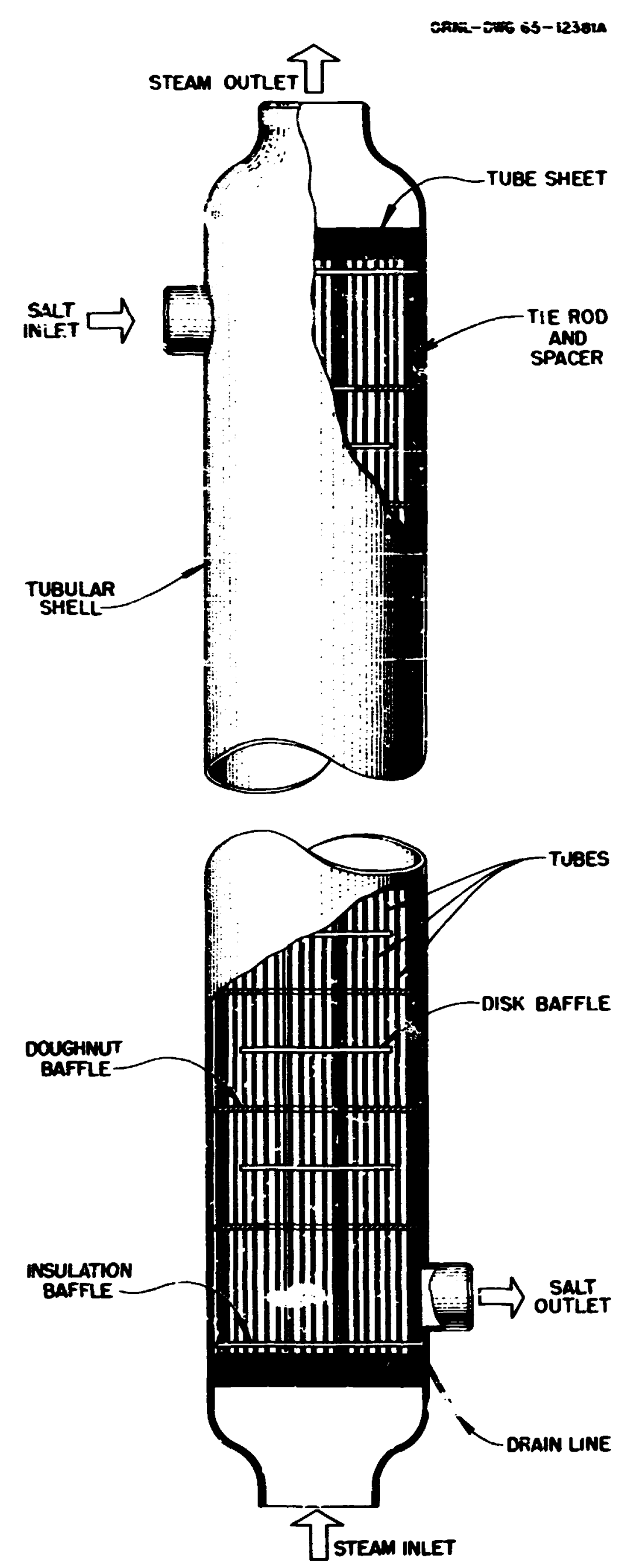

Pia 5.11. Steam Rehenter.

\subsection{Rebeat Stenm Preheaters}

Steam at turbine throttle conditions of 3500 psia and $1000^{\circ} \mathrm{F}$ is used to prelient the reheat steam from 552 to $650^{\circ} \mathrm{F}$ before it enters the reheaters. The eight preheaters, two per module, are single-pass, counterflow, U-tube, U-shell units with the supercritical-pressure steam in the tubes and the reheat steam in the unbaffled shell, as shown in Fig 5.12 Selection of a U sell rather than a divided cylindrial shell permits smaller diameters for the heads and reduces the thickness required for the heads and tube sheets. Principal data are given in Table 5.9. The heat transfer and stress calculations are covered in ORNL. TM-1545. ${ }^{23}$

The preheaters are more a part of the turbine plant than the reactor plant and need not be installed in a sivielded cell nor necesarily manifolded in conformity with the modular arrangement adopted for the reactor plant. Two preheaters have been shown aswocinted with each reactor module, however, primarily as a matter of convenience in the layout.

\subsection{Mainterance}

Maintenance is a major subject for consideration in the design of any fluid fuel reactor, and it is discussed briefly here only because the two-fluid MSBR conseptual studies were discontinued before maintenance procedures could be considered in detail. It was, however, recognized throughout the design effort that it must be possible to repair or replace system components within a reasomable downtime for the plant, and this requirement influenced much of the design. Even though the systems containing fuel salt are drained and flushed, the residual radionctivity will require that all mi:temance be accomplisted by remoteiy operated tools and equipment. The off-ens systems will also require remote maintenance. On the other hand, most of the coolant salt system components can probably be approsched for direct maintenance after flushing and elapee of a short decay time. Little or no radioactivity should be present in the steam and feedwater systems even during full-power operation.

As mentioned in Sect. 2, the radiation damage to graphite will make it necesury to repiace the reactor core vesel several times during the lifetime of the plant. Since the two-fluid MSBR concept does not lend itself to use of a removable top cover for the reactor vewel to gain access for replacement of the core graphite, it was decided that use of four small reactors or modules, with replacement of an entire reactor vesel and core 
anembly, would be more prectical than in-place mintenunce of a single, iaroi reactor. Replacement of a module would require cutting of the salt piping and withdremal of the asembly upward into a shielded trmaport cast for transfer of the spent unit into a shielded pit for ci ay and ultimate dixposal. A shopaxembled and tested replacement module would be standing by. The salt-piping stubs would be previousty machined for welding through use of a jis which matches the installed pipiniz system.

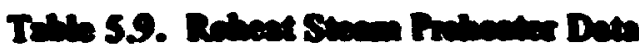

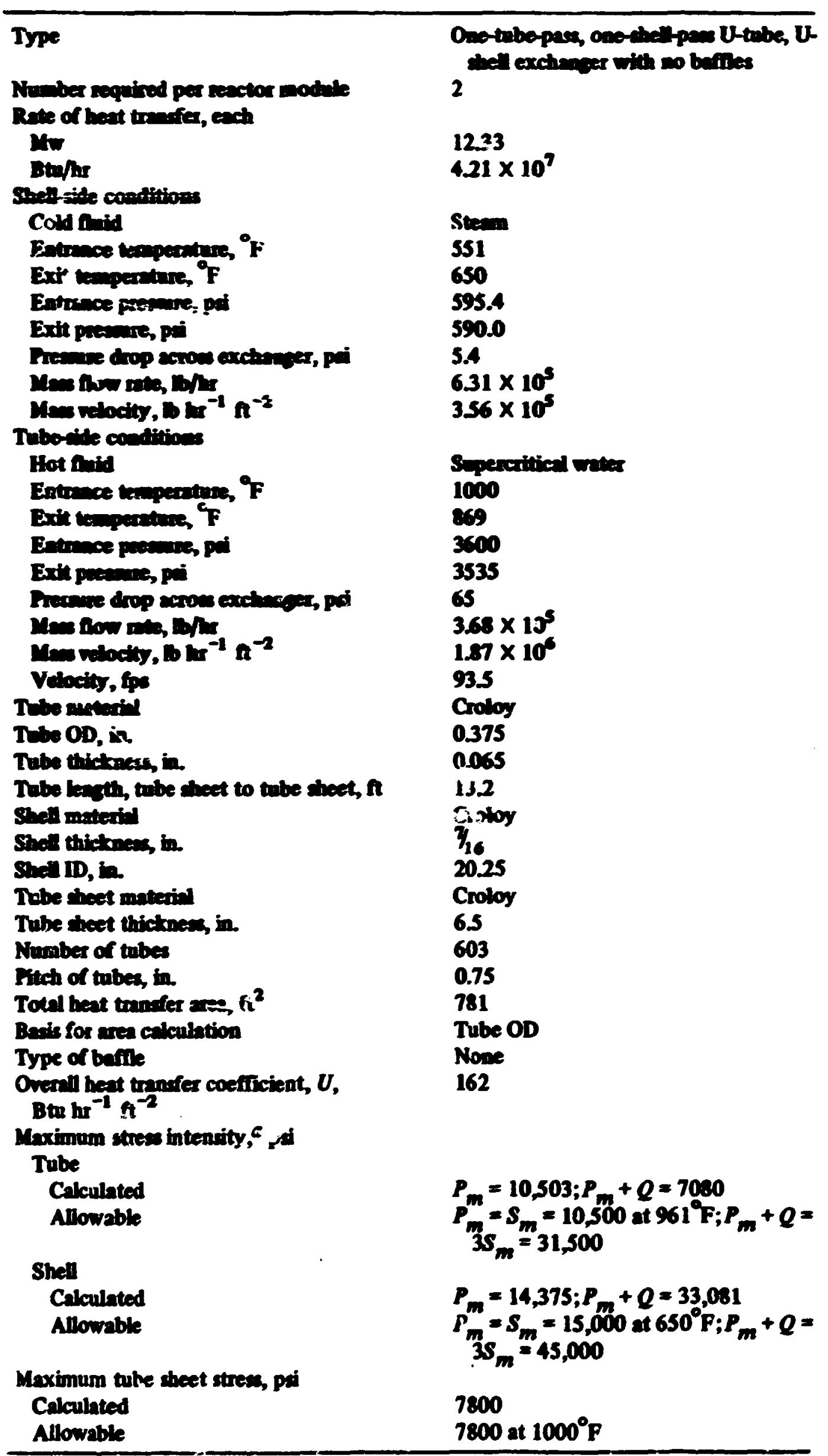




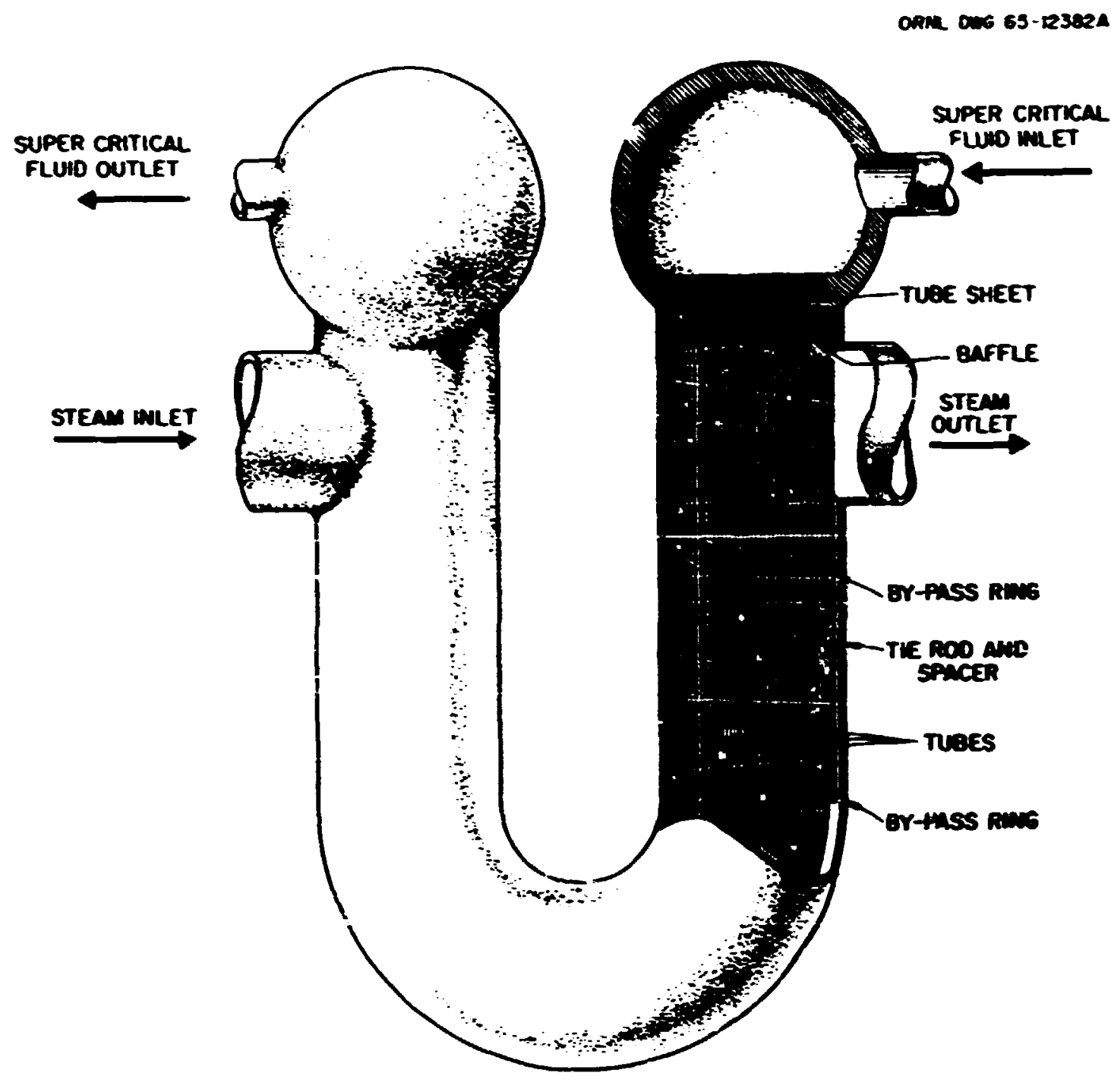

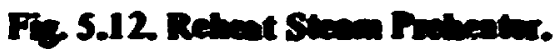

If a ninjor tube leak should occur in the primary heat eschanger, it would be necescary to replace the entire heat-exchanger-pump assembly. The procedure would be to cut the large fuet salt pipes and the two inlet coolant salt pipes, to cut the seal welds, and unbolt the large flange at the bottom of the shell. The exchanger could then be liited from the cell, dixengrging the central coolant salt pipe at the sip joint provided for this purpose. Drain, fill and drain, gas pressurization, and several other consections must also be cut when removing the exchanger.

The rotating nurts of the fuel alt circulating pump can be withdrawn upward after the drive motor has been set aside. This is a relatively simple operation that does not require breaking the salt piping connections.

The type of mintenance of a large MSBR reactor plant described here requires the cutting and welding of alt piping by remote means. Some original work by the Air Force has been modifiec and is being developed by $\mathrm{Holz}^{36}$ at ORNL to provide this sapability. A compact orbital system is designed to be clamped around the pipe and has interchangeable modules and a weld programmer for cutting, beveling, tungaten-arc welding, and inspection. Preliminary tests have produced welds of acceptable quality in 6- and 8-in.-divm pipes with fully remote operation.

Much valuable experience bas teen gained at the MSRE with remote maintenance operations similar to those required for a larger molten-alt reactor. The use of jos and optical tonling has proven to br a practical and expeditious methat of fitting replacement parts and components into the existing system.

The first cost of the special equipment required for maintenance operations is a part of the capital cost of the plant. This has been included in Table $7.1 \mathrm{a}$ an aliowarce, since conceptual dexigns for the equipment were not available. The cost of the materials used in replacement of reactor modules and the special labor forces required are included in the power production cost as a separate item (see "able 7.2). (Some may wish to inclute this expense with the fuel-cycle cost; others may consider it to be an operating cost.)

\footnotetext{
${ }^{36}$ Peter P. Holz, Feasibitity Study of Remore Culiturs and Welditis for Nuclear Plant Medntenance, ORNL-TM-2712 (November 1969).
} 


\section{REACTOR RIYSCOS AND FUEL CYCUE ANALYSTS}

\subsection{Optimintion of Reactoi Praneters}

In addition to the so-called conservation coefficient discused in Sect. 2, which reintes specific imventory and breeding gain. two other principal indices by which the performance of a moltearsalt breeder reactor can be exhuated are the cost of power and the anound fuel yield. The latter two indices were ueed as foures of merit in aswasing the influence of various desizn Farameters and. the effect of design changes on the two-ituid MSBR.

We customarity combine the cost factor and the fued yield, that is the anmual fractiond increase in the ieventory of fimionble materisl, into a composite faure of merit

$$
F=y+100(C+x)^{-1},
$$

in which $y$ is the anmud fivel yield in percent per year, $C$ - that paet of the power cont which depends on any of the parameters consideme, and $X$ is an adjustable conctant, heving no physical significance, whose value merely determines the relative sensitivity of $F$ to $y$ and C. Since a brge number of reator parmineters are invived, we make use of an automatic earch procedure, carried out on a compuier, which finds that combination of the variable desigr parameters that maximizes the fogure of merit $F$ subjeci to whatever constraints ney to imposed by the fixed values of other design parameters. This procedure, called OTIMERC, ${ }^{31}$ incorpontes a multigroup diffusion calculation (synthrxizing a two-spece-dimensional description of the fhux by alternating one-dimensional fhux calculations), a determination of the fixile, fertile, and fivion product concentrations consiatent with the procesing rates of the fuel and fertile salt streams, and a method of steepest gradients for optimizing the values of the variables. By choosing different values for the conetant $X$ in the figure of merit $F$, we can generate a curve siczing the minimum cost ascosiated with any attainable value of the fuel yieid. By carrying out the optimization proceduric for different auccessive fixed values of seccted design parameters, we obtain families of curves of $C$ as a function of $y$.

One of the design parameters which has a significant influence on both yield and power cost is the power

\footnotetext{
${ }^{37}$ In OFTMMERC sny of some 20 parameters may be either anded fred vilues or be allowed to vary within specified runits subject to the optimization prosedure.
}

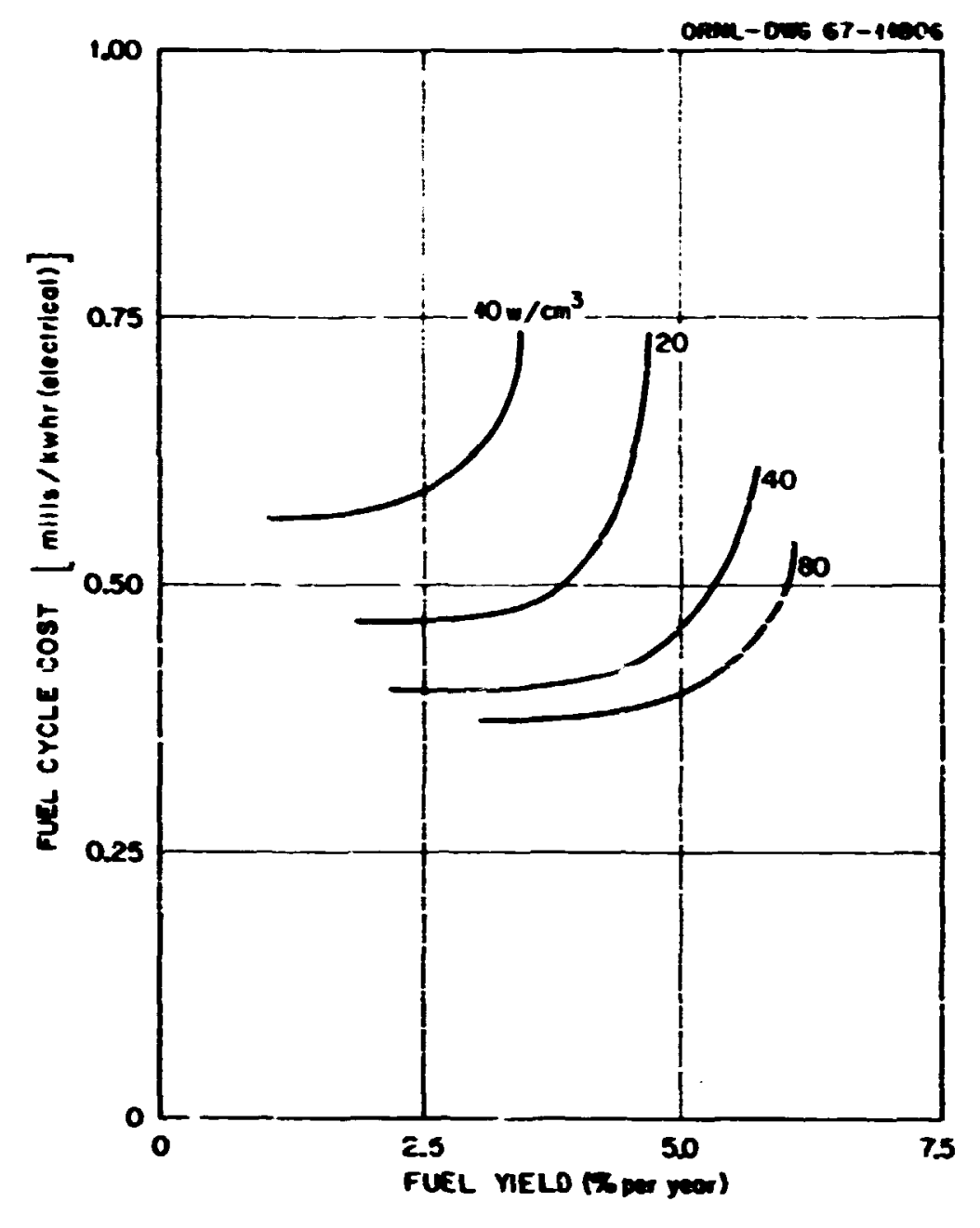

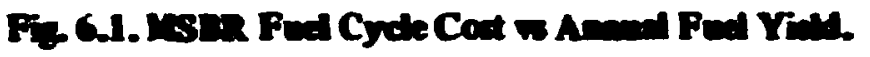

density is ive core. The performance of the reactor is bether at high powier densities Ai the same tine, the uneful life of the saphite moderator, which is dependent on the total exposure to fast neutrons, is inversely proportional to the power density (see Table 5.1 and Sect. 6.2). It is necesary, therefore, to determine the effect of power density on performance with considerable care.

In Fiz. 6.1 the fuel-ycle cons is used bycause it reflects most of the ysintions of power cost due to the influences of the parameters being varied. It may be sen from Fig. 6.1 that a reduction in average power density from 80 to $20 \mathrm{w} / \mathrm{cm}^{3}$ inmolves a fuel-cycle cost penalty of about $0.1 \mathrm{mill} / \mathrm{kwhr}(\mathrm{e})$ and a reduction in annual fuel yield of perhaps 1.5\%. There is an increase in the capital cost of the reactor, but this is offeet somewhat by a reduction in the cost of replacing the graphite (and the reactor vesel) since this can be done at leas frecuint intervals. The penalty for having to replace the graphite (compared with a high-powerdensity core not requiring replacement) is about 0.2 mill/kwhr(e). The capital cost portion increases and the replacement cost portion decreases with decreasing power density so that the total remains about constant. 

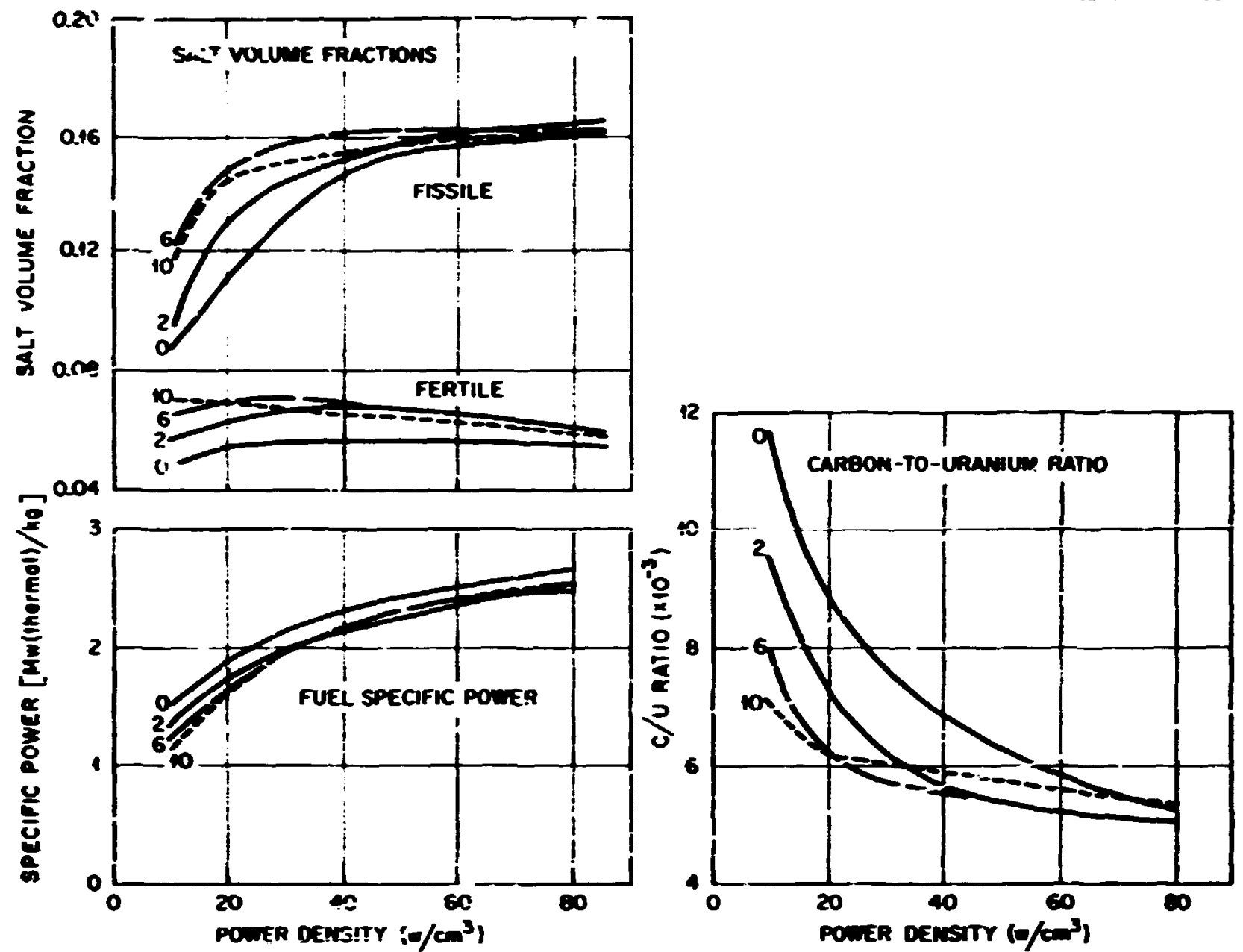

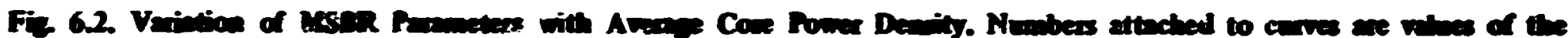

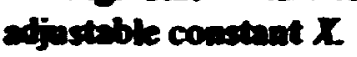

Figures 6.2 and 6.3 sinow the variation of other selected parameiers with power density and the adjueteble constont $X$. For given values of power density and $X$, the corresponding values of the setected parameters are those of the reactor with the optinum combination of yield and fuel-cycle cost.

It is apparent from these resuits that the use in life of the Faphite is not increased by reducing cose power density without some sarrifice in other aspects of reactor performance. The reduction in yield and the increase in cost sie quite modest fos a reduction of power disusity from $80 \mathrm{to} w 1 / \mathrm{cm}^{3}$, but they become increasinely rejic significant for each further factor of 2 red!: iion in power density. Nonetheless, as showis in Fis. 6.1, it appears that with an average power density as low is $20 \mathrm{w} / \mathrm{cm}^{3}$ the MSBR can still achieve an annual fuel yield of 3.5 to $4 \%$ and a fuel-cycle cont of atrinti 0.5 milijikwhr(e).

The fuel-cycle cost extimate for the $40-w / \mathrm{cm}^{3} \mathrm{cos}$ figuration aummarized in Fiz. 6.1 is shown in more detail in Tables 6.1, 6.2, 6.3, and 6.4. The economic ground ruies for the fuel-cycle cost calculations ate given in Table 6.1. The worth of the fasile isotopes was taken from the AEC price schedules. The capital chrnges of 13.7\%/year for depececinting item and 10x/yea for nondeprecinting materiets are typieal of thoue for privately owned plants under 1968 conditions as shom in Appendix Table A.12.

Results of the fuel-ycle calculations for the MSBR decign are summarized is Table 6.2, and the nenton baiance is given in Table 6.3. The reactor hes the

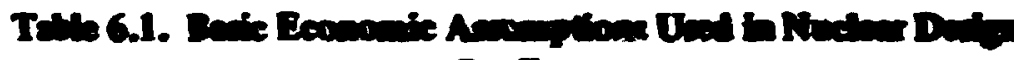
Stansies

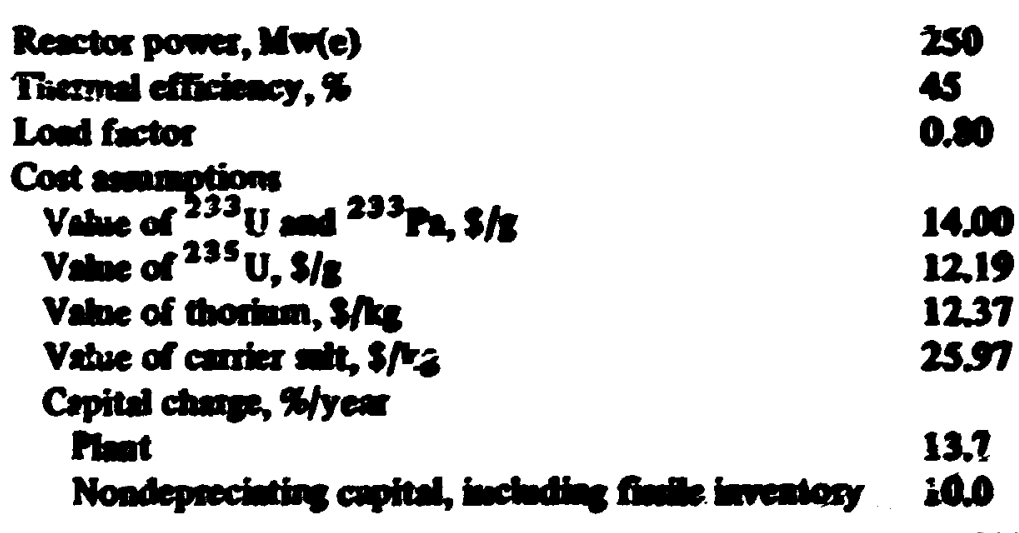



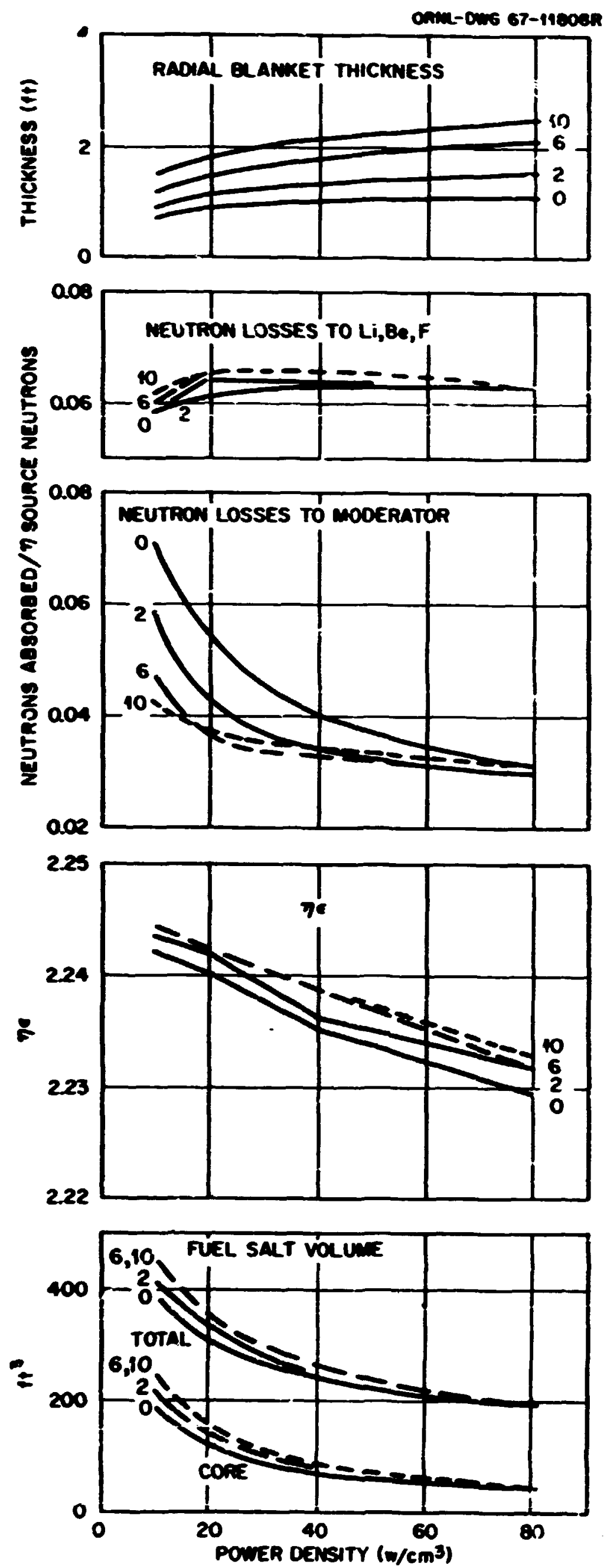

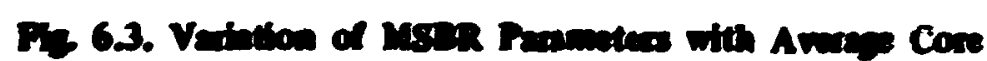
Powne Denclity. Nusibers atuched to curves are values of the ajponble condunt $x$.

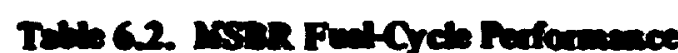

Fod yind, $x$ fyee

Dovedion mis

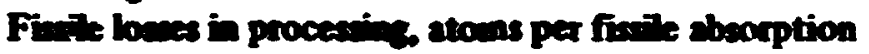

Nowtros production per ficele sbocoption (in)

0.0040

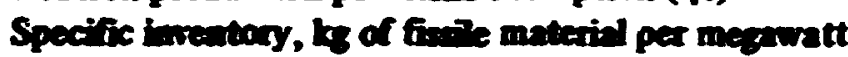

of electrinity produced

2.22

Specific power, Mw(t) per lo of fisile material

1.26

Power dewidy, cone suarege, kw/liter

Groes

In foel silt

Frection of fiacions in fued strean

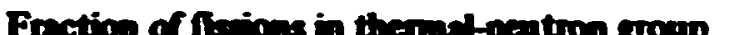

Keon a of $235 \mathrm{U}$

Nem $n$ of $^{235} \mathrm{U}$

2.225

1.981

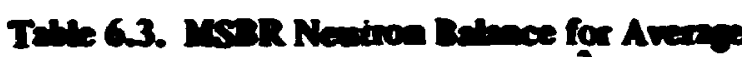
Pown Deming of 20 witem

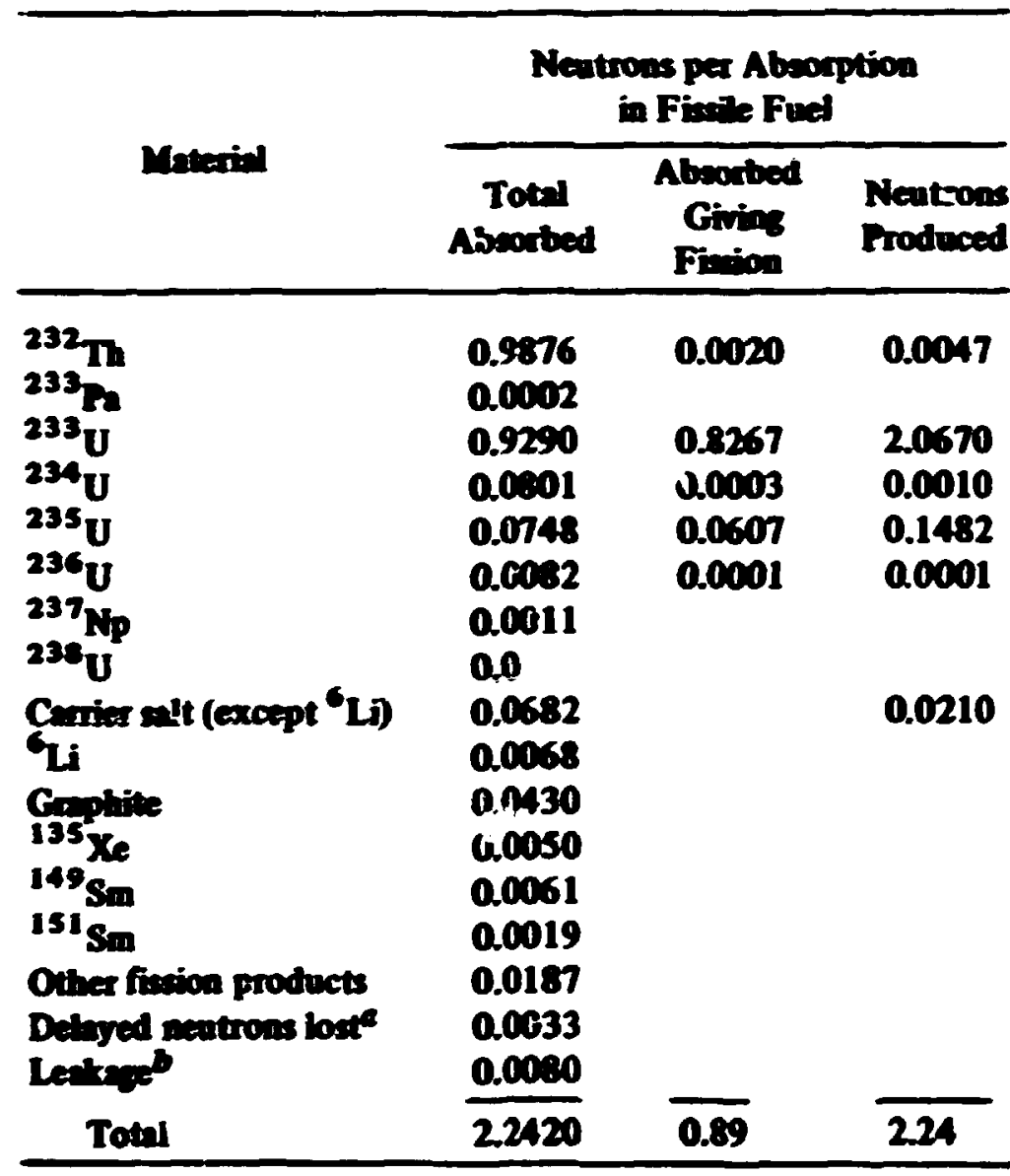

Delyyed neutrons emitted outside the core.

Leatore, inchedies seatroms absited in the refiector.

advantage of no seutron loses in structural materials in the core other than the moderator. Except for come unavoidable loss of delayed neutrons in the external fuel circuit, there is almost zero neutron leakage from the reactor because of the thick blanket. The neutron lowes to fiscion products are minimized by the rapid integrated procesuing.

The portion of the fuel-cycle cost due to processing loses is shown in Table 6.4 and is based on a fertile 


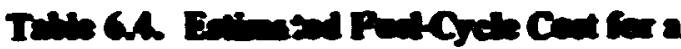

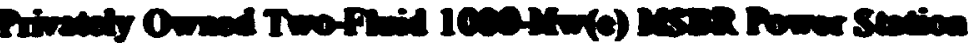

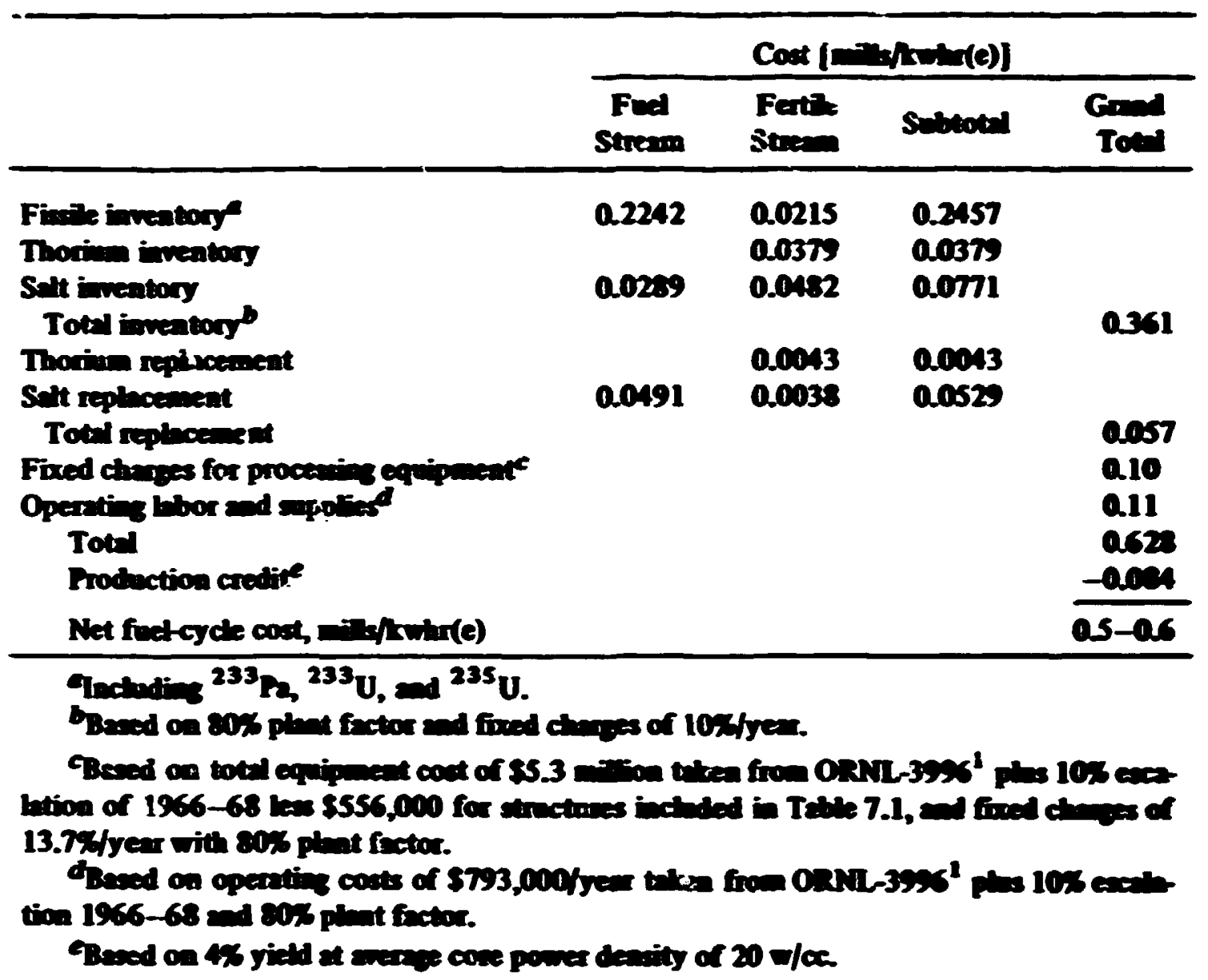

material loss of $0.1 \%$ per pas through fuetrecycle processing.

The fuet-ycle costs for fixed charges on procesing equipment are based on cost atimates published in ORNL-3996, but eacalated by 10\% to 1968 conditions. The operating costs for labor and plant supplies (other than salt inventories and makeup) specifically related to the chemical procescing portion of the power station are also based on the ORNL-3996 extimate with 10\% escalation, as shown in Table 6.4.

It may be noted in Table 6.4 that the man cost items are for the fissile inventory and the procesaing costs. The inventory costs are rather rigid for a given reactor design, since they are largely determined by the fuel volume external to the reactor core region. The

Table 6.5. Procening Cycle Times with $x=2$

\begin{tabular}{|c|c|c|c|}
\hline \multirow{2}{*}{$\begin{array}{c}\text { Power Denaity } \\
\left(\bar{w} / \mathrm{cm}^{3}\right)\end{array}$} & \multicolumn{3}{|c|}{ Cycle Time (dxys) } \\
\hline & Fuel Stream & Fertie Streem & $\mathbf{P a}$ \\
\hline 80 & so & so & 0.5 \\
\hline 40 & 77 & 70 & 0.7 \\
\hline 20 & 110 & 110 & 1.1 \\
\hline 10 & 173 & 144 & 1.4 \\
\hline
\end{tabular}

procesaing couts are, of course, a fonction of the procescing-cycle times, one of the chief purneted optimized in this study. The procesing cycle times for the optimized cose with $X=2$ are given in Trble 65. The cycle times show a systematic increase with decreasing power deneity.

\subsection{Undill tite of Madecter Goingere}

Information used in the two-fhuid MSBR sturies regarding the dependence of graphite dinescions changes on fast neutron dose wrs derived primaty from experiments carried out in the Domereay Fad Reactor (DFR).

A curve of volume change is fast neutron doce for a nearly isotropic graphite at temperatures in the rane 550 to $600^{\circ} \mathrm{C}$ is shown in Fis. 6.4, which is triten frow the paper of Henson, Perte, and simmosis ${ }^{38}$ The seutron dose in Fiz. 6.4 is expreaned in terms if an

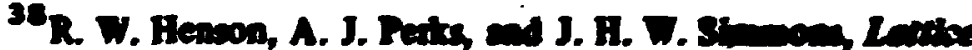

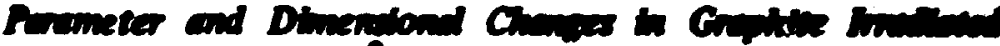

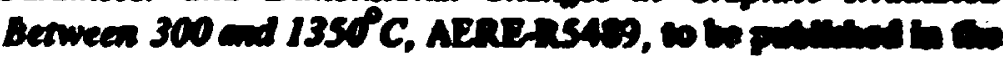

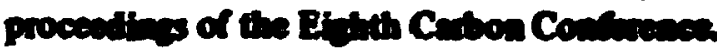




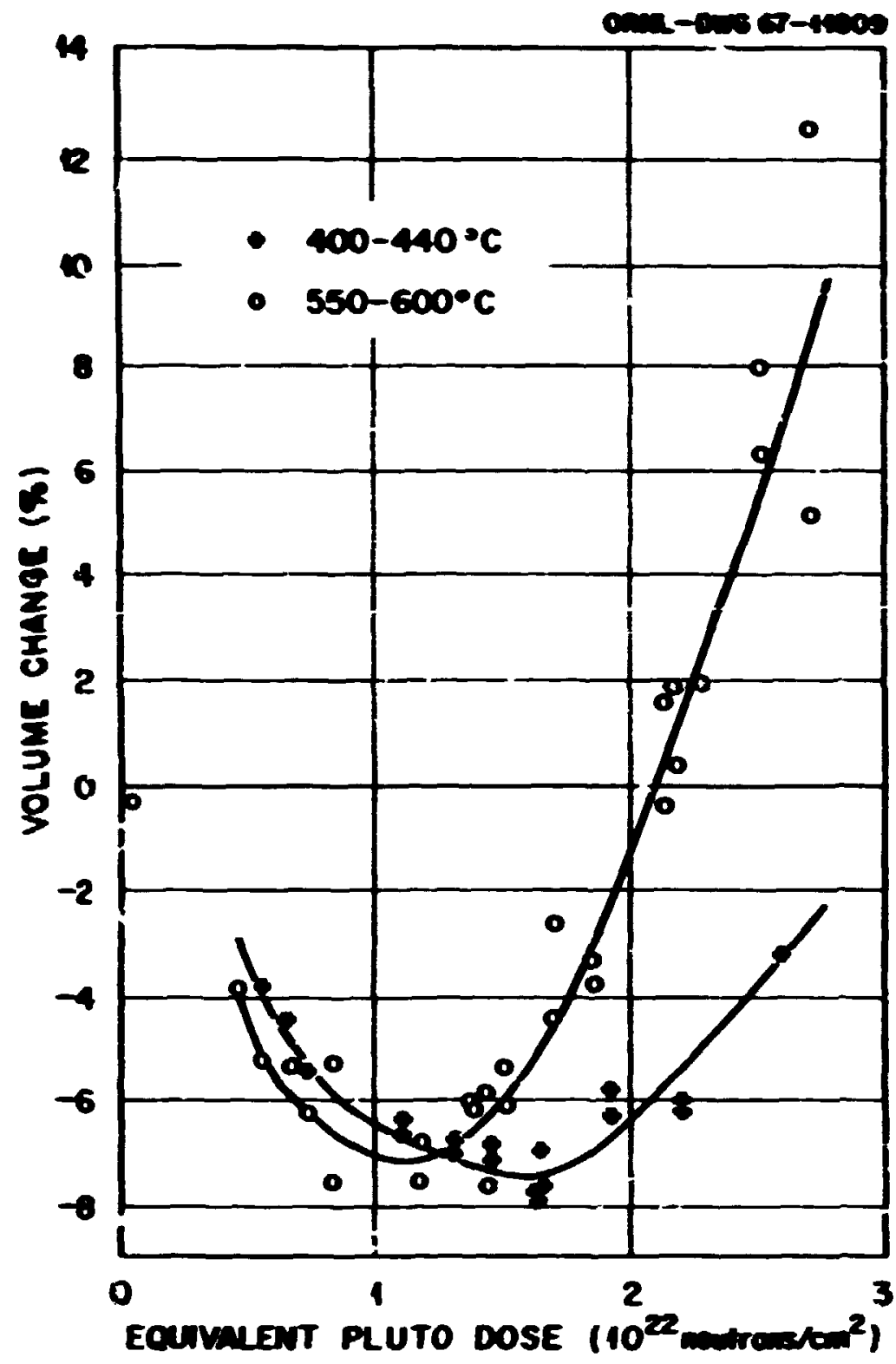

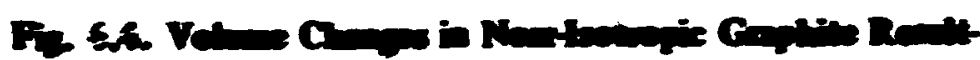

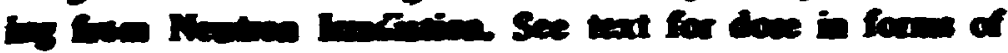
mis fax

eqpivilent Pinto doce; the toml DFR dowe, that is,

$$
\int_{0}^{T} \int_{0}^{-} x(E, t) d E d t
$$

is 2.16 times the equivelent Puto dose. From an inpection of all the avizble data, we conchaded that a dowe of bout $2.5 \times 10^{22}$ neutrome/ $\mathrm{cm}^{2}$ (equivilent

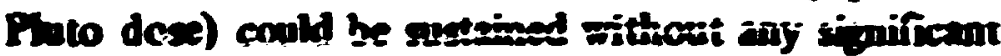
deteriontion of the physicel properties of the graphite. This wes adopted as the ellowable doce in thex MSBRR studien, peading further detailed consideration of mechenical dexipn problems that might be acocinted with dimensional charges in the graphite.

In order to interpret these experimenas to obtain predietions of grephite damage is tine in tine moltenalt reactor, it is recesary to take into sccount the difierence between the neutrun spectrum in the DFR and in the MSBR. This in turn, requires asoumptions regring the effectivenes of mentrons of difierent eneries for probicing the observble effects with which ose is concerned. At present the beat eppitoech arible is to base the extimates of neutron danoe effectivenes on the theoretical calculations of graphite

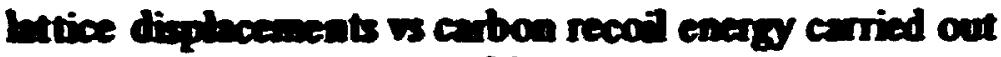
by Thoopeos and Writh" Their "damaze function" is integreted ova the dintribution of cabon recol cactios resalting irom the scattering of a neutron of a given enersy, and the resalt is then multiplied by the enery-dependent scattering cros section and integreted one the weatron spectron in the reactor. Teats of the model wese mede by Twompen and Wright by colcalating the rate of electrical recistivity change in oxphite rehtive to the ${ }^{58} \mathrm{~N}(\mathrm{E}, \mathrm{p})^{58}$ Co reaction, in diferent reactor spectra, and the dita were compared vith experinentul detenimations of the seme quantitien The resules indicate the the model is a lest usefui for predicting rebaive danoe mtes in differext spectra. The pecterl effects are discuined more fully by Peny in CiNLIM-2136..$^{2}$

A wefil ieplification aises from the obsermation that the denger par wit tien is closely proportiond to the toul wemtron in a bove sane enery $E_{0}$, where $E_{0}$

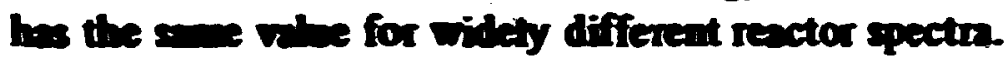
We hrve reconfined this observation to our own exiefuction by conpeing the calcalated dasere per un $f x$ sbove exery $E_{0}$ as a function of $E_{0}$ for pectur spproprinte to three differeat modentro $\left(\mathrm{H}_{2} \mathrm{O}\right.$, $\mathrm{D}_{2} \mathrm{O}_{2}$ and C) and for a "typicai" fast reactor spectiom The remits plotted in Fic 6.5 shom that the flux above about $50 \mathrm{ke}$ is a reliable indication of the rebative

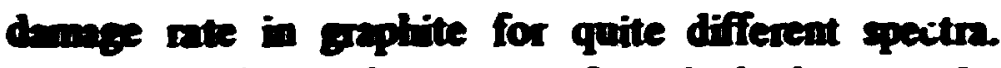
Figure 6.6 shows the spectra for which these results were derived. The equivilence between MSBR and DFR experiments is found by equating the dowes doe to neutross above 50 ker in the two reactors. We have not yet calculated the DER spectruns explicitly, but we expect it to be sinitar to the "fact reactor" spectrum of Fis 6.6, in which $94 \%$ of the total fenx lies above 50 ker. Since the demage flux in the MSBR is essentivily propirione to the local power deneily, we postulate that the useful life of the graphite is governed by the maximum power density rather than by the averexe, and thus depends on the degree of power flottening that can be achieved (see Sect. 6.3). In the two-fhid MSBR the swerne flux above $50 \mathrm{ker}$ is about $0.94 \times 10^{34}$ neutrons $\mathrm{cm}^{-2} \mathrm{sec}^{-1}$ at a power demity of $20 \mathrm{w} / \mathrm{cm}^{3}$.

${ }^{39}$ M. W. Thompere and S. B. Writht, J. Nuch Meser. 16, 146-S4 (1935). 


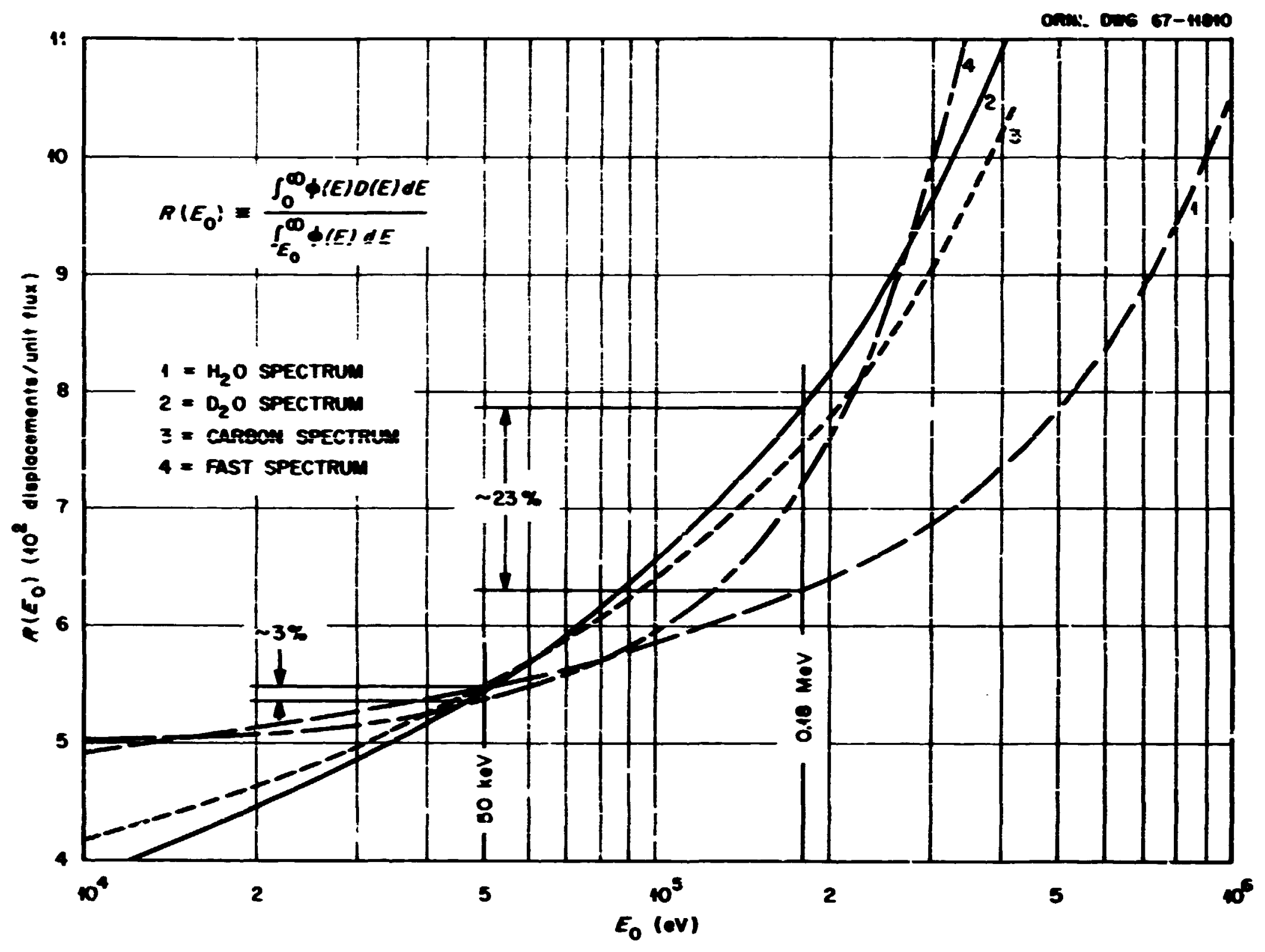

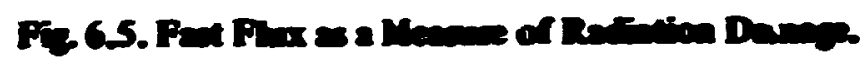

In the DFR irradintions the equivent Pluto dose of 2.5 $X 10^{22}$ neutrond $\mathrm{cm}^{2}$ that was taken $\mathrm{a}$ the tolereble exposure for the graphite is a dose of $5.1 \times 10^{22}$ neutrone/ $\mathrm{cm}^{2}$ (\$SO kev). ${ }^{40}$ The approximate ueful lifetime of the graphite is then exily computed and is shown in Table 6.6 for various combinations of the averno power deneity and peak-to-avernge power dencity ratio.

It Inisi be acinowiediged that some uncertainties remin in applying the results oi DFR experiments to

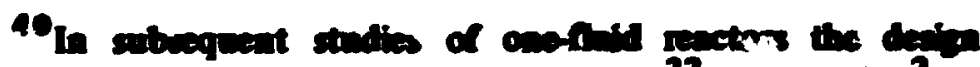

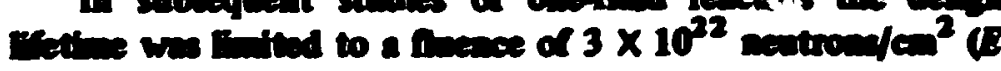

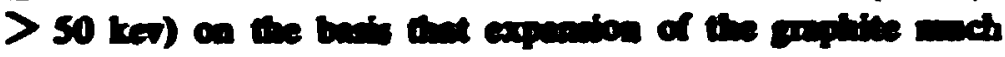

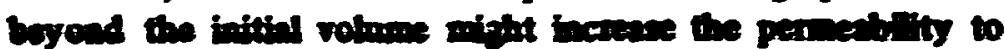

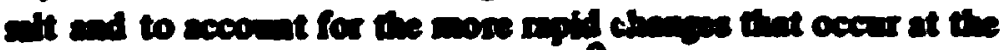
Linter tempentures of 700 to $720^{\circ} \mathrm{C}$ is the enplite. Mose

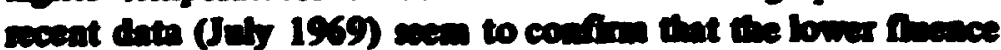

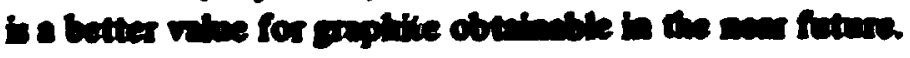

\begin{tabular}{|c|c|c|}
\hline $\begin{array}{c}\text { Areane Rower } \\
\text { Dwiy } \\
\left(n / a^{3}\right)\end{array}$ & & Les \\
\hline $\begin{array}{l}40 \\
40 \\
30 \\
20\end{array}$ & $\begin{array}{l}20 \\
15 \\
20 \\
15\end{array}$ & $\begin{array}{r}4.3 \\
5.7 \\
86 \\
11.5\end{array}$ \\
\hline
\end{tabular}

the MSBR, inctuding the posibitity of an apprecinble depeadesce of the damage on the rate at which the dose is sccumalated, as well as on the totsl doce. The dose nte in the DFR was aproximately ten tines greater than that expected in the MSBR, and if there is a significant dowerate effect, the life of the crophite in m MSBR might be apprecinbly longer than shom in Table 6.6. 


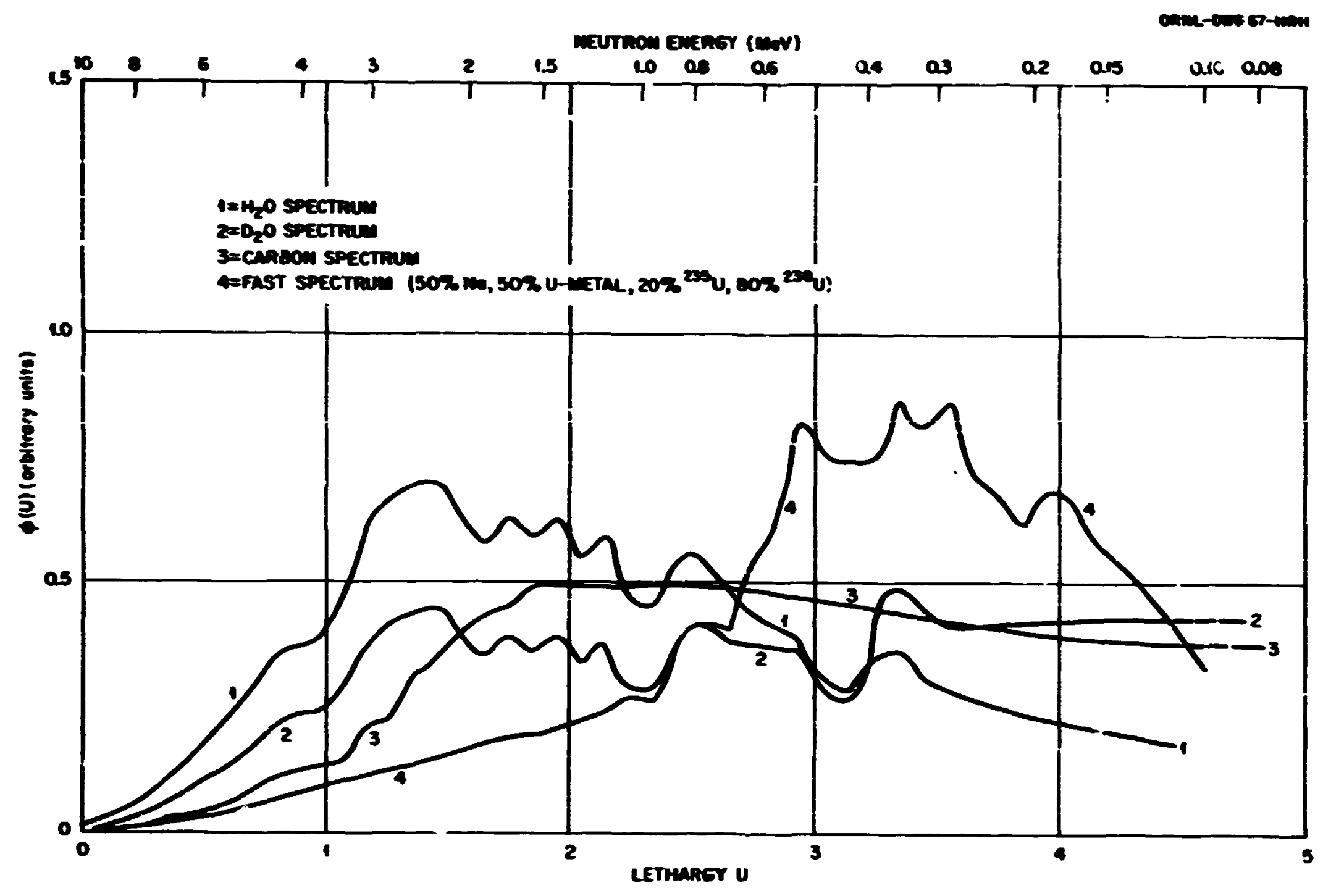

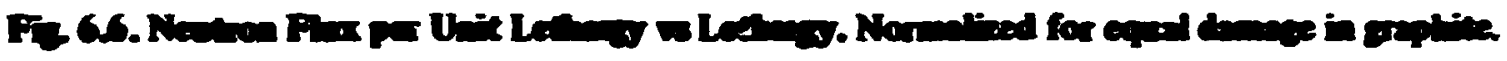

\subsection{Fin Fidtenges}

Beceuse the useful life of the graphite moderator in the MSBR depends on the maximum value of the danare flux rather than on its sverge value in the core, there is obviousty an incentive to reduce the maximumto-verage flux matio as much as powible, provided that this car be scomplished withcut serious penalty to other appects of the reactor performance. In addition, there is an incentive to make the temperature sise in parallet fuel paseses through the core as nearty uniform a posible, or at least to minimize the maximum devintion of fuel outlet temperature from the average value. Since the damage thux (in effect, the total neutron flux above $50 \mathrm{kev}$ ) is exenti-lly proportional to the fivion density per unit of core volume, the first incentive requires an attempt to flatten the power deneity per unit core volume throughout the core, that in in both radiol and axial directions. Since the fuel moves through the core only in the axial direction, the second incentive requires an attempt to flatten, in the adial direction, the power dencity per unit volume of fuei. Both objectives can be accomplished by mintrining a uniform volume frection of fuel selt throughout the core and by flattening the power deneity distribution in both directions to the greateat extent ponible.

The general approach taken to flattening the power distribution is the clasical one of providing a central core zone with $k_{-} \cong 1$, that in, one which is neither a net producer nor a net absorber of neutrons, surrounded by a "buckied" zone whose surphus neutron production just compenentes for the neutron leakage through the core boundary. Since the fuel alt volure fraction is to be kept uniform throughout the core and since the concentrations of both the fuel and the fertile alt stream are uniform throughout their respective circuits, the principal remining parameter that can be varied with position in the core to schieve the desired effects is the fertile salt rolume faction. The problem then reduces to findires the ralue of the fertile alt volume fraction that gives $k_{-}=1$ for the central, 
flatened 2one, with fixed values of the other parameters, and finding the vohume fraction of the fertie silt in the buckled zone that makes the reactor critical for different sizes of the flattened zone. As the fraction of the core volume occupizad by the fattened zone is increased, the fertile sit fraction in the buckled zone must be decreased, and the peakto-average powe: density matio decreases toward unity. The bargest fhetened zone and the smallest power density ratio are achieved when the fertile materinl is removed entirely from the outer core zone. Increasing the fuel silt concentration or its volume fraction (with an appropi $;$ ate adjustment of the fertile salt rolume fraction in the fattened zone) would permit a still bryer fattened zone and smaller $P_{\text {max }} / P_{\text {av }}$, but this could be expected to compromise the reactor performance by increasing the fuel inventory.

There are many possible combinations of parameters to consider. For example, it is not obvious, a prioni, whether the flattened zone should have the same height-todiameter ratio as the entire core, or whether the axial buctled zones should have the same composition $s$ the radial buctled zone. While we have by no means completed investigations in this area, we hrve progresued far enough to secognize several important axpects.

First, by flattening the power to various degrees in the radiel direction only and performing fueleycle and economic calculations for each of these canes, we find that the radial power distribution can be markedly fiattened with very little effect on fuel cost or on anmual fuet yield. That is, the radinl peat-tcerveriage power density ratio, which is about 2.0 for the uniform core (which is surrounded by a heavity absorbing blankei rezion and hence behaves esentially $\boldsymbol{x}$ if it were unreflected), can be reduced to 1.25 or less with changes in fuel cout and yield of $k=0$ than 0.02 mill/kwh(e) and $0.2 \%$ per year respectively. The enhanced neutron leakege from the core, which results from the power fattering, is taken up by the fertile blanket and does not represent a low in breeding performance.

Second, attempts at power flattening in two dimensions have shown that the porver distribution is very sensitive to details of composition and placement of the flattened zone. Small differences in upper and lower blanket composition, which are of no consequence in the case of the uniform core, produce pronounced axial asymmetry of the power distribution if too much axid flattening is attempted. In addition, the axial and radial buckled zones may interact through the flattened zone to some extent, giving a distribution that is concave upward in ose direction and concave documward in the other, even though the integrated neutron current over the entire boundary of the central zone vanishes. In view of these tendencias, it my be anticipated that a flttened pomer distribution would be difficult to mintuin if graphite dimensional changes, resultion from exposure to fast neutrors, were allowed to influence the silt volume fractions rery strongty. Consequenthy, a core of the decion shom in Fie. 5.4 was under comsideration as a means: of relucing the seneitivity of the power distribution to graphite dimensional changes.

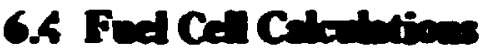

A series of calculations was performed to invationte the muclear characterietics of the two-fluid MSBR fuel cells, or elements. Thexe were based on the geometry shown in Fis 6.7. (Subsequent to these calculations, a graphite sleere was added around the fertile salt.)

The cell calcoktions were performed with the code TONG and involved varying (1) cell dinceter, (2) fuel distribution (i.e., fuel separation distance), (3) ${ }^{233} U$ concentration, (4) ${ }^{932} \mathrm{Th}$ concentration, (5) fuel selt volume fraction, and (6) fertic silt volume fraction. Exch of these parametess was vaied seperately while holding the othes conetant. Figure 6.8 shows the efiect

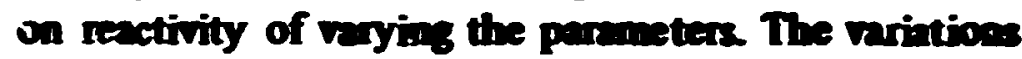
are hown relative to a refereace cell which had a dimeter of 3 in., a fuel separation diatence of $4 / 4$ in, a fuel alt frection of 0.1648 , and a fertie sult fraction of 0.0585 , with $\sim 0.2$ mole $\%^{23}{ }^{23} \mathrm{~F}_{4}$ in the focl wat and 27 mole $\% \mathrm{ThF}_{4}$ in the fertile alt.

These calculations showed that 2 the cell dismeter increases, the increased self-ghisding of the ${ }^{232} \mathrm{Th}$ resonances leads to an increase in the reactivity of the cell. Thws a decrease in breeding rativ asocinted with the decreaved ${ }^{232}$ Th resonance integral is sccosupanied

com ons reters

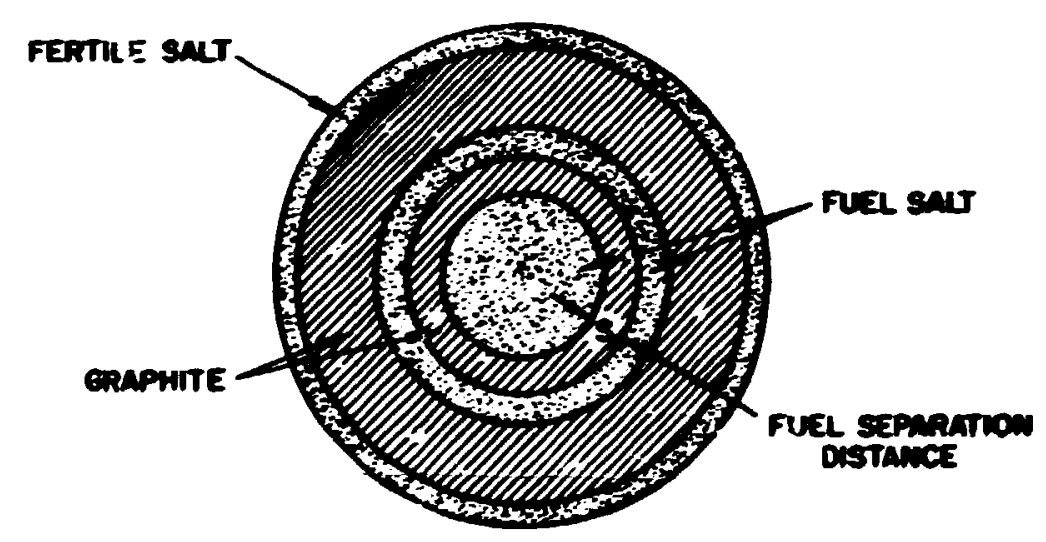

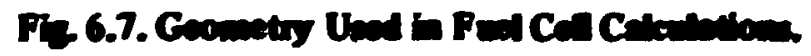




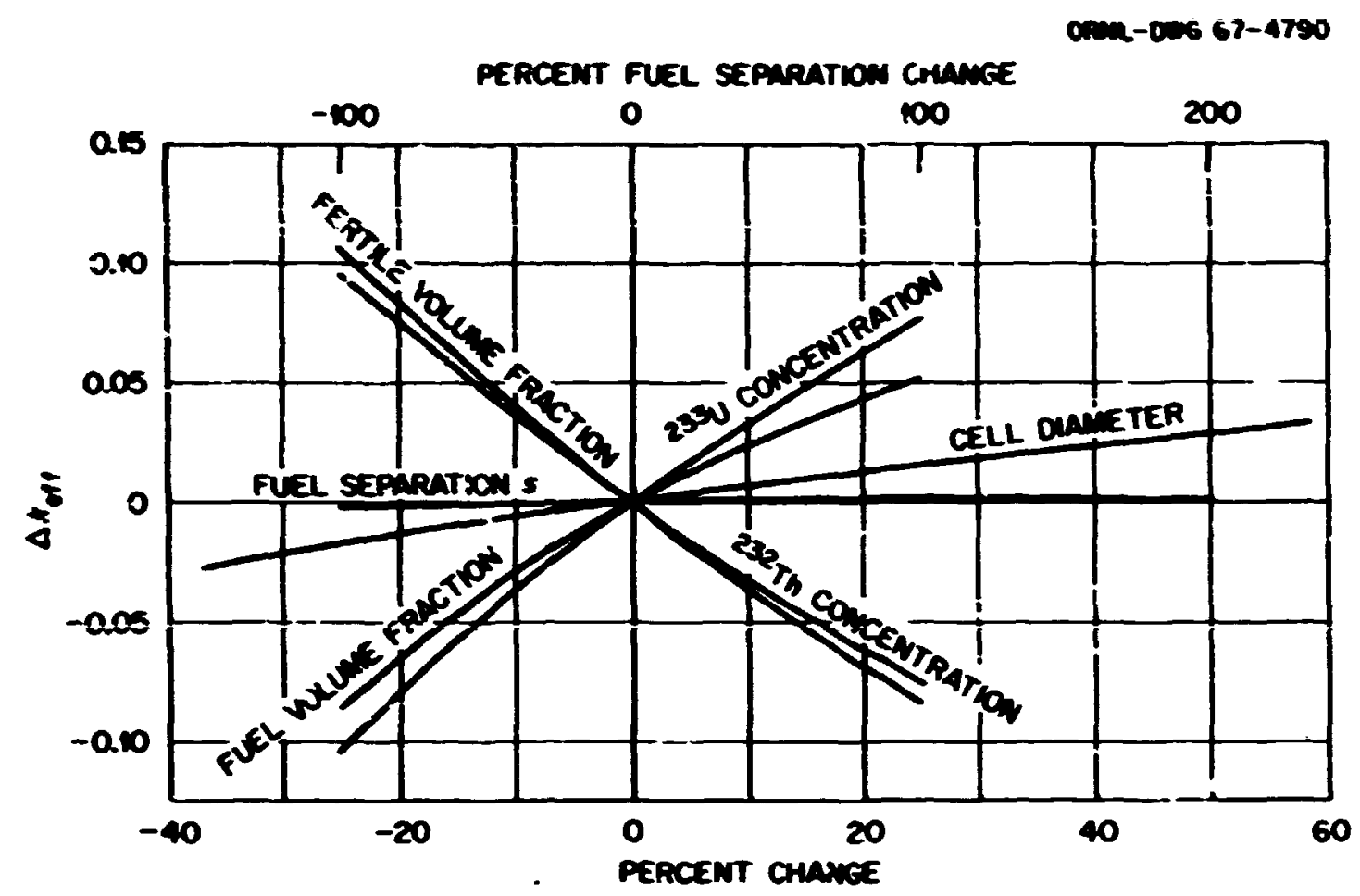

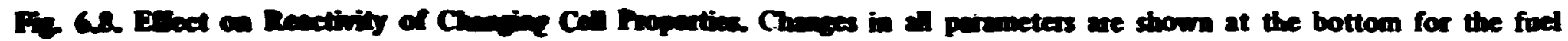
equonion the is slowe at the top.

by a decrese in the required ${ }^{23}{ }^{3} \mathrm{U}$ lodine Optimiza tion colculations wing cross rections besed on 3 - and 5in-ding cells indicated that the arnual fuel yield of the system is enentiolly insencitive to fuel cell diometers between 3 and 5 in. This is significant because the bye cells are preferred for hydrodynamic reasons, purticularty in order to achieve the decired Reynolds numbers for the fuel silt flow in the channets.

Table 6.7 and F 6.9 shom the flux distribution in the 5-indinm cell. Table 6.7 gives the ratio of the average flux in the fuel to the cell average flux, the ratio of the average fhux in the grophite to the cell average flux, and the ratio of the average flux in the fertile salt to the cell average flux for the epithermal and fast flux ranges. Figure 6.9 shows the thermal flux distribution in the cell.

Two-dimensional diffusion-theory calculations indicated that the central cell of the reactor may be useful for control purposes. For example, if the central cell is a 5-in. 0 D $\times$ 4-in.-D graphite tube and if this completely empty tube is filled with fertile alt, the change in reactivity is $\delta k / k=-0.018 \%$. If the empty tube is filled with graphite, the reactivity change is $\delta k / k=$ $+0.0012 \%$. Thus there appears to be a substantial mount of reactivity control available by varying the beight of the fertile column in the tubes, which might be accomplished through use of a movable graphite plue.
Tolle 6.7. Fux Rnios in Epitherand and Pant Bnow Renges

\begin{tabular}{|c|c|c|c|}
\hline \multirow[t]{2}{*}{ Eneds Rnere } & \multicolumn{3}{|c|}{$\begin{array}{l}\text { Ratio of Averaxe Flux } \\
\text { to Cell Avate Flux }\end{array}$} \\
\hline & Feel & Gophite & Fentile \\
\hline $\begin{array}{l}0.821-10 \mathrm{Med} \\
0.0318-0.821 \mathrm{ker} \\
1.234-31.82 \mathrm{kew} \\
0.0479-1.234 \mathrm{ked} \\
1.86-47.9 \mathrm{er}\end{array}$ & $\begin{array}{l}1.226 \\
1.090 \\
1.014 \\
1.0 \\
1.0\end{array}$ & $\begin{array}{l}0.929 \\
0.924 \\
0.998 \\
1.0 \\
1.0\end{array}$ & $\begin{array}{l}0.878 \\
0.958 \\
0.991 \\
1.0 \\
1.0\end{array}$ \\
\hline
\end{tabular}

\subsection{Tempersuture Coefificients of Reactivity}

In analyzing power transients in the two-fluid MSBR, one muax be able to determine the reactivity effects of temperature changes in the fuel alt, the fertile salt, and the graphite morlerator. Since the fuel is also the coclant and since only small fractions of the total heat are generated in the fertile salt and in the moderator, one expects very much smaller temperature changes in the latter composents than in the fuel during a power transiant. Expansion of the fuel alt, which removes fuel from the active core, is thus the principal inherent mechaniem for compensating any reacivity additions. We accordingly calculated the magnitudes of the temperature coefficients of reactivity separately for the fuel salt, the fertile salt, and the graphite over the range 


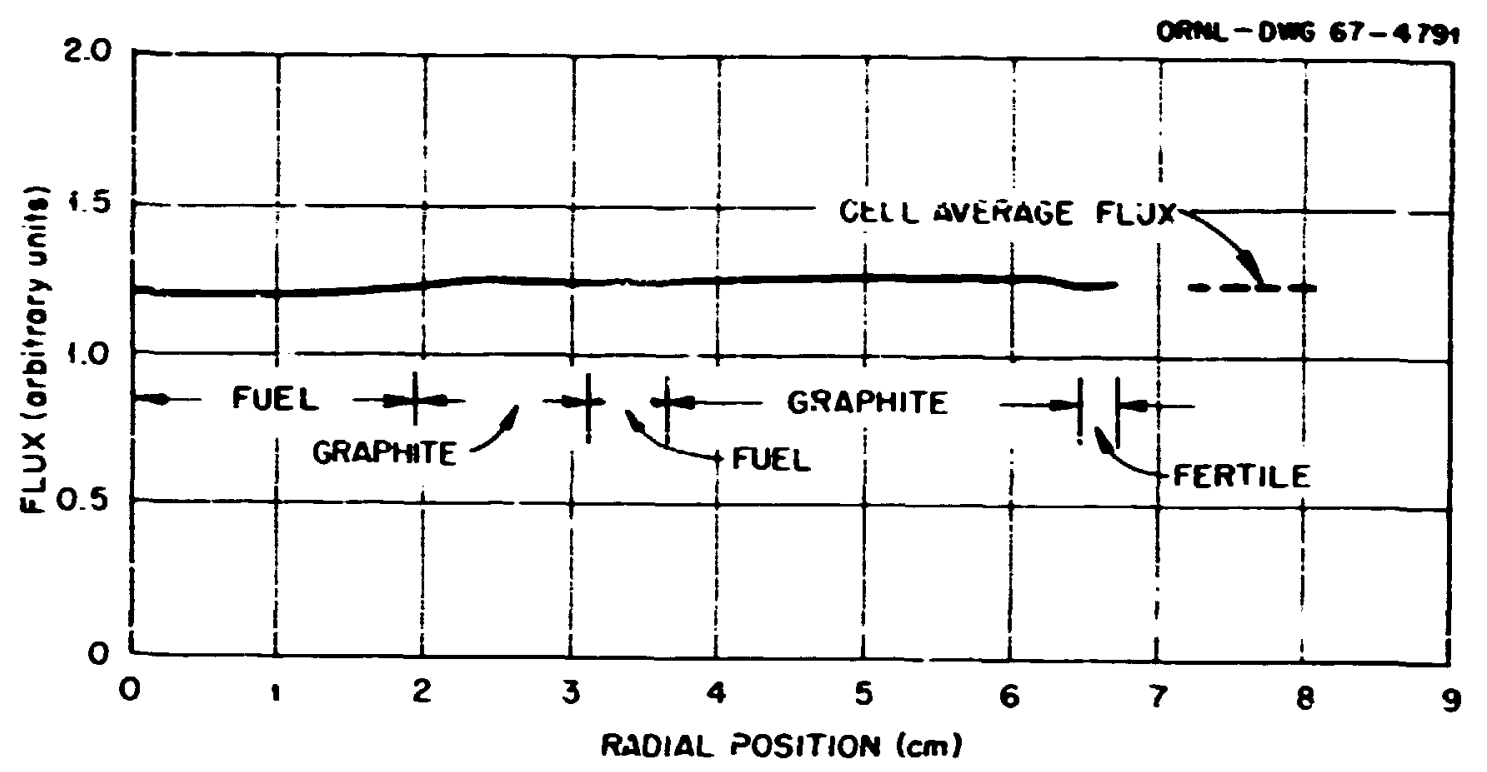

Fo 6.9. Thenal Flax Distribetion in Cell $E<1.86 \mathrm{er}$.

of temperatures from 800 to $1000^{\circ} \mathrm{K}$. The results of these calculations, as shown in Fiz. 6.10a, illustrate the change in multiplication factor vs moderator temperasure (with $\delta k$ artitrarily set equal to zero at $900^{\circ} \mathrm{K}$ ). Similar curves of $\delta k$ vs temperature for fuel and fertile salts are shown in Figa $6.10 b$ and 6.10C, and the combined effects are shown in Fig. 6.10d. All these curves are nearty linear, the slopes being the temperature cosfficients of reactivity The magnitudes of the coefficients at $900^{3} \mathrm{~K}$ are shown in Table 6.8.

The moderator esefficient comes almost entirely from changes in the spectrum-averaged cross sections. It is particularly worthy of note tinat the moderator coefficient appears to be quite insensitive to uncertainties in the energy dependence of the ${ }^{233} \mathrm{U}$ cross sections in tine energy range below $1 \mathrm{ev}$. This is to say that reasonable choices of cross sections based on available experimental data yield essentially the same coefficient.

The for ile salt reactivity coefficient comprises a strong positive component due to salt expansion (and hence reduction in the number of fertile atoms per unit core vclume) and an appreciable negative component due to temperature dependence of the effective resonance-absorption cross sections, so that the overall coefficient, though positive, is less than half as large as that due to salt expansion alone.

The fuel alt coefficient is due mainly to expansion of the salt, which of course reduces the average density of fuel in the core. Even if all core components were to undergo equal temperature shanges, the fuel salt coeff: cient would dominate. In tr.susients in which the fuel

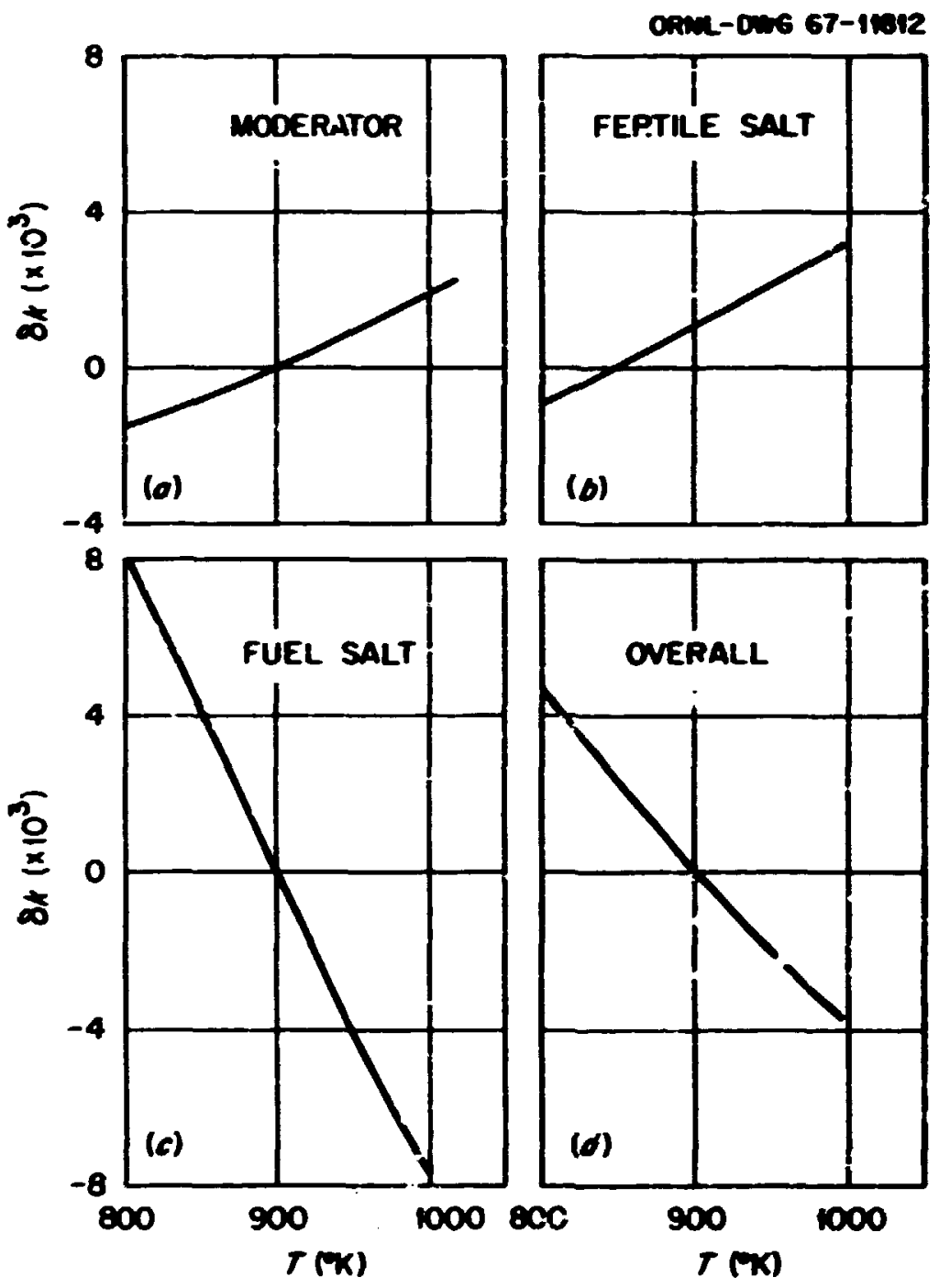

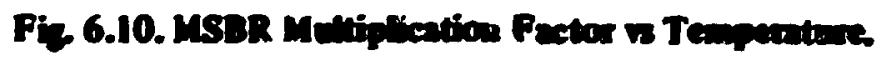

temperature change is far larger than that of th: other components, the fuel coefficient is even more controlling. 


\begin{tabular}{|c|c|}
\hline Component & $\begin{array}{l}\text { Coeficiont } \\
\frac{1}{k} \frac{d k}{d T}\left[\left({ }^{\circ} \mathrm{K}\right)^{-1}\right]\end{array}$ \\
\hline & $\times 10^{-5}$ \\
\hline $\begin{array}{l}\text { Moderntor } \\
\text { Fertile salt } \\
\text { Fod salt } \\
\text { Overall }\end{array}$ & $\begin{array}{l}+1.66 \\
+2.05 \\
-8.05 \\
-4.34\end{array}$ \\
\hline
\end{tabular}

\subsection{Dymmice Amblysis}

The dynamic behovior of the MSBR, particularly the reactor stability, was investignted using a linearized model of the two-fhuid system. The model included a lomped paremeiter representation of the neutronics (inchudin pure time delays for out-of-core precursor tramport), fuel alt heat transfer in the core, fertile salt weat irasifer in the core, fuel alt heat exchanger, and the salt sin- of the boiler and reheater. The heat removel from the boiler and reheater was assumed conutant. The remiting model consisted of 34 coupled differentinl equations with 15 pure time deiays.

The ationtes of the temperature coefficients of smetivity for the fuel elt, fertile salt, and graphite were mined during the course of these dynamics calcula. tione sume of the calculations were based on the early rines and some were based on the later ones. Both valus are shown in Trble 6.9. The neutron generation time was $3.3 \times 10^{-4}$ sec.

The mociel was used for analyses of system stability, tramient responac, and frequency response. The stawatity analyxis (using the newer temperature coefficients in Table $\therefore$, a mecomplished by employing the modified Mithailov method described by Wright. ${ }^{41}$ The malysis showed that the system is linearly stable.

The aability of the system is also indicated by the reponse of the system to step changes in reactivity. The linearized response of the reactor power to a step change of $10^{-4} \Delta k / k$ is shown in Fig. 6.11. This curve based on the old reactivity coefficients given in Table 6.9. Since the model is linear, the response to some other reactivity step is the product of the co $1 \mathrm{~L}: \perp$ response and the ratio of the new reactivity

\footnotetext{
11W. C. Witht, An Efficient, Computer-Ortented Method for Swably Amalych of Very Lore System, distertation corr fleted at the Csiverity of Tennescee, June 1968.
}

Town 69. Renetivity Conoficients (Ak/k pas ca)

\begin{tabular}{lrr}
\hline & Ori Value & New Value \\
\hline Fed silt & $-4.6 \times 10^{-5}$ & $-4.54 \times 10^{-5}$ \\
Fertile salt & $+1.43 \times 10^{-5}$ & $+2.12 \times 10^{-5}$ \\
Graphite & $+5.1 \times 10^{-6}$ & $+9.2 \times 10^{-6}$ \\
\hline
\end{tabular}

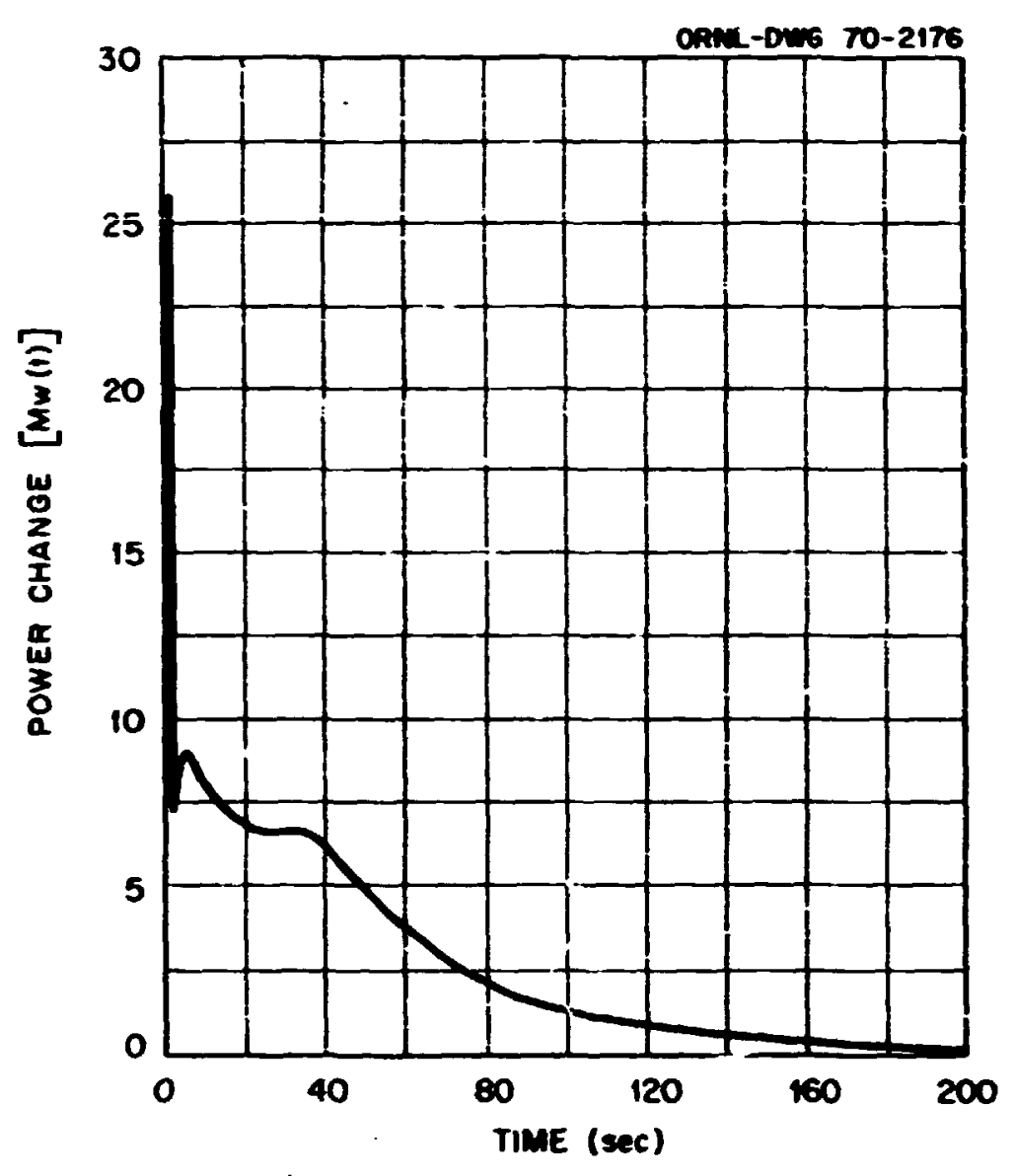

Fe 6.11. Power Twanient Pollowing a Reactivity Slep of $10^{-7} 8 k / k$ with Reactor Operating at 556 Mult).

to the old reactivity. The linear results are obviously not valid for large reactivity inputs, but would be aufficiently accurate for transients in which the power changes by less tian 10\%. The response shown in Fig. 6.11 is expressed as the deviation from the full-power output [556 $\mathrm{MW}(\mathrm{t})]$ of a single ractor module.

The power-to-reactivity frequency response of the reactor is shown in Fiza. 6.12 and 6.13 for the case of full-power operation. In this instance the results are based on the newer reactivity coefficients given in Table 6.9. As would be expected from the transient response results, there are no tall peaks in the frequency response amplitude which would indicate strong resonance behavior. The frequency response was also computed using the old reactivity coefficients. Since the change in the results was very small, the transient resporse calculations were not repeated. 


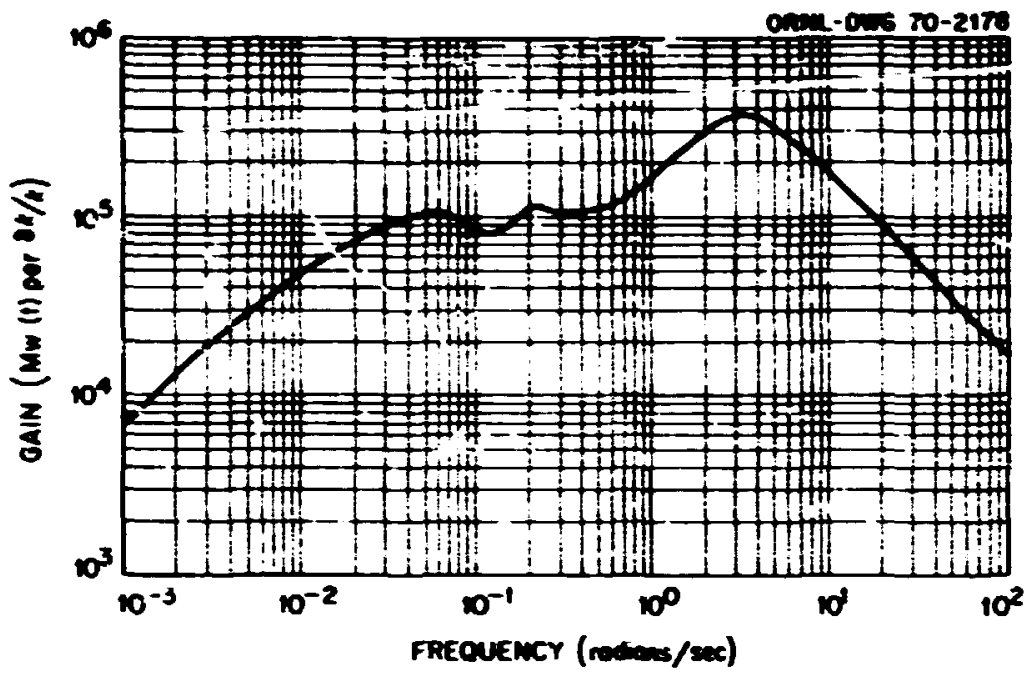

Fiz 6.12. Ampitude of the Powneto-Reactivity Frequency Respones Reactor at în power.

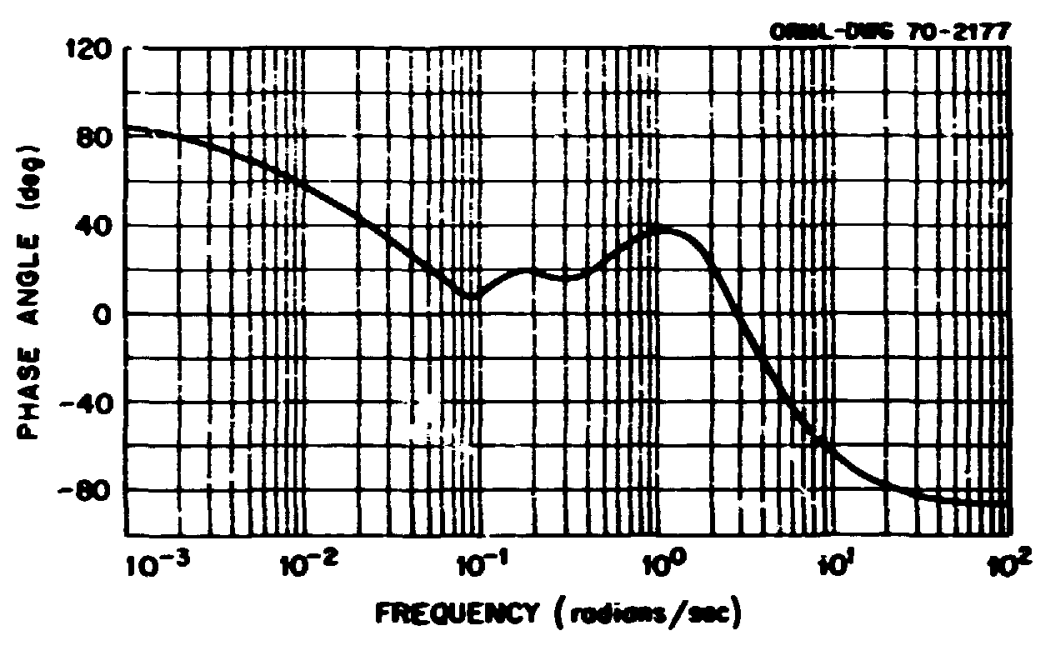

Fiz 6.13. Thase of the Fome-to-Renctivity Propoency Resposse. Reactor at fon power.

In general, the system is well behaved dynamically, and satixfactory operation should not be difficult to obtain.

\section{COST ESTMUATES}

\subsection{General}

One of the promising aspects of the molten-salt breeder reactor is the potential for producing low-cost power. At the present atage of development, accurate detailed cost estimntes are not poseible, but our best estimate of the construction cost of a two-fluid $1000 \mathrm{Mw}(e)$ MSBR station is alvoit $\$ 140 / \mathrm{kW}(e)$. This extimate is in terms of early 1968 conditions and value of the dollar, and includes indirect costs. The estimated net cost to produce power with private ownership of the plsnt is sbout 4 mills/kwhr.

In making the cost atimntes we asoumed that an established molten-salt reactor industry exists and that raterials are being supplied and phants are being constructed and licensed on a routine basis. We abso assumed that the indirect charges, or owren's costs, for a molten-salt reactor are mot siznificantly diffizent from those for other types of reactors.

Although the chemical reprocessing phant is of the reactor station, not all the chemical piant costs are included in the estimate of the station contruction cost. The cost of the shielded cells to ho'se the chemical plant is included in the overall structures sccount for the reactor phant, but the cost of the processing equipment, the furl and blanket salt invent tories, and the operation of the chemical plant was kept separate from the rest of the static n costs in order to arrive at a fuel cycle cost which is comparable with the fuel cycle costs for other types of nuclear power stations. The estimated fuel cycle cost is sbout 0.5 mill/kwhr, or about 0.7 mill/kwhr if the expense of periodic replacement of the reactor vesuels and graphite cores is included. This is lower than has been projected for most other types of nuclear power piants and accounts for much of the interest in molten-alt reactors.

The coets reported here for the two-fluid MSBR are higher than those published in ORNL-3996' in 1966. This is primarily because of changes in the plant concept, modifications to the design due to revisions in the physical properties data, and escalation of costs beiween 1966 and 1968 . The present extimate of the direct construction cost is about the same as the estimeted cost for a pressurized-wnter reactor of $1000-M m(e)$ size built on the same site. Because the accuracy of the estimates is uncertain, we think the major value is in comparing MSBR and PWR costs to learn where the inherent differences in the systerms have an important bearing on the relative costs of the two kinds of plants. Two areas stand out: The allownce for maintenance is less on the PWR, but the cost of the turbine-generator is less for the MSBR.

\subsection{Condruction Costs}

The estimate of the construction cost of a two-fluid $1000 \mathrm{M}(\mathrm{w})$ MSBR power station is summarized in Table 7.1. Tables A.1 through A.11 in the apperdix give nore-details of the costs. About half the total construction cost is for conventional parts of the plant, such as structures, turbine-generator, etc., for which 


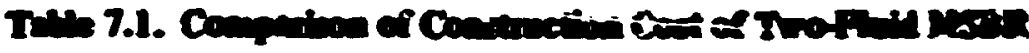

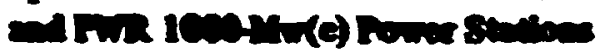

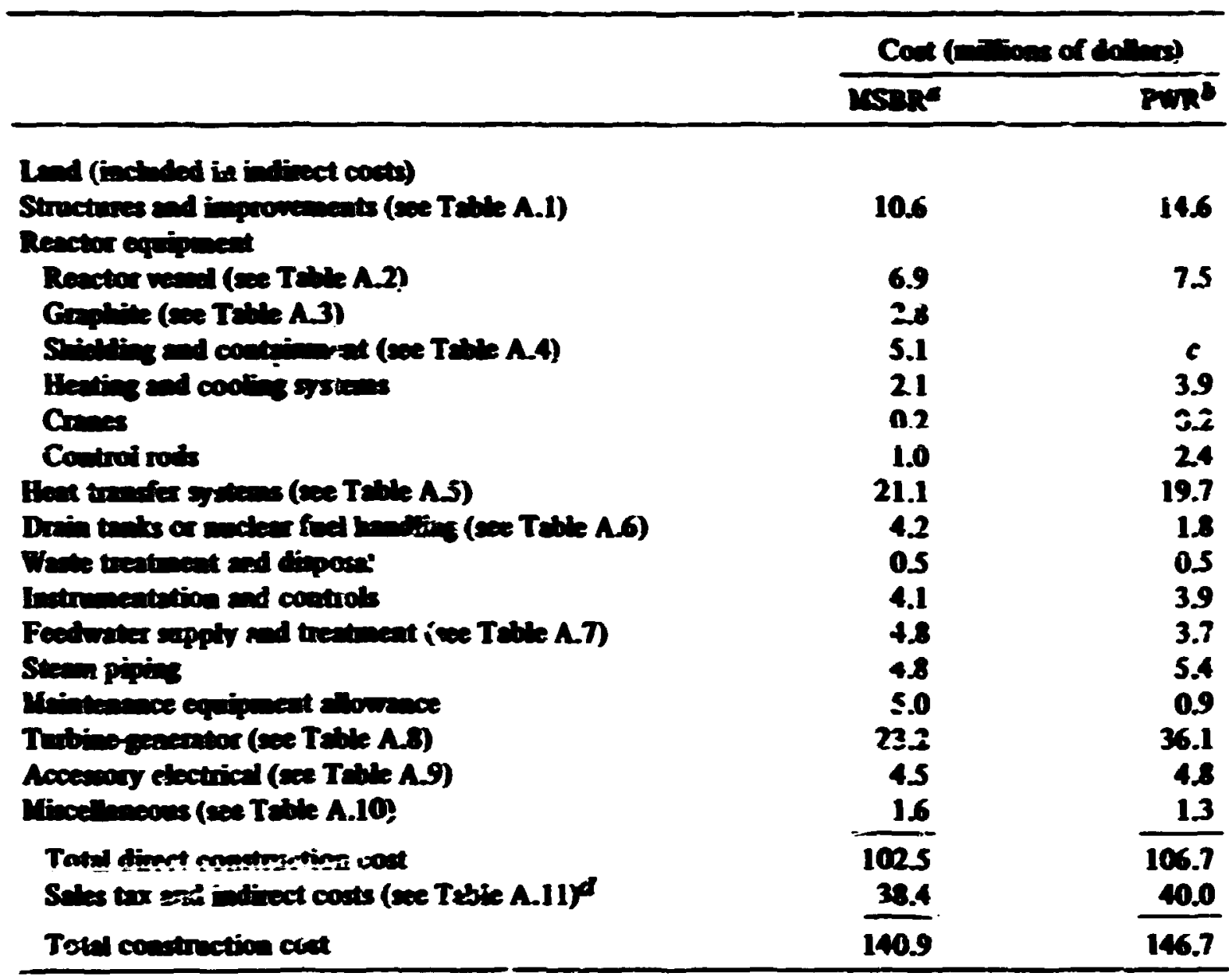

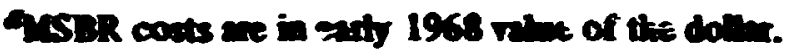

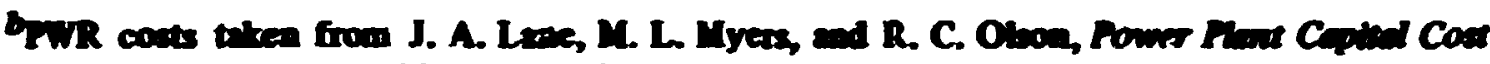

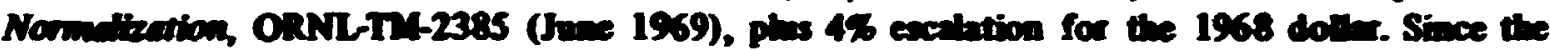

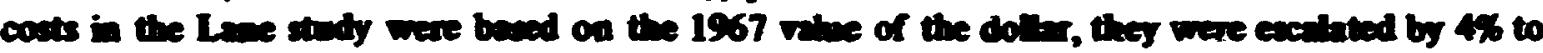

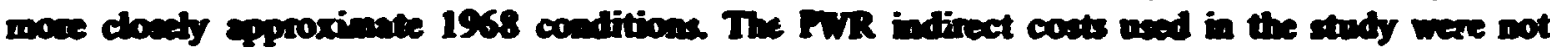

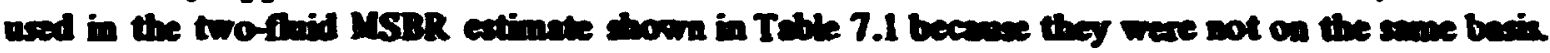
For simplicity, the sere vale for indirect costs of $33.5 \%$ wes applied to the direct condruction cost of both the MSBR and FWR. A sles tax of 3\% wa added to the conetruetion cost of both types of plants.

TWR shiviling cost inchuded in atrectures and improvenents.

dAsomes $3 \%$ miles tax and LSBR indivect costs 33.5\% as shown in Table A.11.

costs are relatively well establisined. The reactorassociated conts are less certain because of the preliminary nature of the designs and the use of special graphite and Hastelloy $\mathbf{N}$ for which there is no experience in large-scale production and fabrication.

With rezard to the graphite, a long-term cost of $\$ 5 / 1 b$ (see Table A.3) was used in these estimotes. More recent studies by Cook et al. ${ }^{42}$ suegest that the price could approach 58/13. Installed costs of Hastelloy N com-

\footnotetext{
12W. H. Cook, W. P. Eatherly, and H. E. hicCoy, Estimati" of Core Graphtie Cos, ORNL internal correspondunce MSR-68-150 (Nor. 1, 1968).
}

ponents were assumed to vary hetween $\$ 8$ and $\$ 20 / \mathrm{lb}$, depending upon the form of the Hastelloy $\mathbf{N}$ and complexity of construction, as shown in Table A.2.

A few of the items listed in Table 7.1, such as maintenance equipment, are subject to considerable uncertainty because little design soork was completed in those areas. A study by slumberg ${ }^{3}$ indicated that about $\$ 5$ nitlion asuuld be allowed for maintenance equipment fr: the MSRR station.

\footnotetext{
${ }^{43}$. Bhumbers Prelliminary Cost Estinate for Remote Madnenance of the MABR, ORNL internal correpondence MSR-68-140 (Oct. 14, 1968).
} 
The comparative couts sivon in Teble 7.1 for a TWR station were tiken from the nomblizacion studies by Leme et $d^{\text {t4 }}$ The MSSR and PWR codts ure about equid in many areas, but in at least two instances the differences are werthy of note:

1. Tite zeintenance equipment required for repbcement of the resctor vesis in the MSBR staivid is included as a capital expente. This allownise is considercbly higher than correaponding PWR costs. The replaconini costs in terms of the materinb and specin bbor required were handled separateby, as dincussed in Sect. 7.3.

2. The cost of the turbinegenerater and asocinted turbine plant equipment is mesct lisis for the MSBR station bersese ii operates at about $45 \%$ thermal eficiency. as compared with the 33\% thermal effi ciency of the PQR, and it uses supercritical-presoure steam rather than the low-pressure steam of the maier reactor plant.

\section{Power Froduction Con}

The total cost to produce elesisic pomer in a privately owned 1000M/r(e) troffuid MSPR staion is exti mated to be about 4 millefwhr. The coets are summarized in Table 7.2. The fuel cycle cost is sufficiently bow that even the addition of the expense of periodically rephacing reactor vaseb and graphite results in a combinal cost of only about 0.7 mill/kwhr. The net cost of about 4 mills/kwhr to oroduce electricity is attractively low.

The fixed charge of $13.7 \%$ used in making the extimates is explained in Table A.12 in the appendix. In extimating the depreciation allowance, a 30-year plant life was ascumed in order to be consistent with other reactor craluation studies. The posibility that the low fuel cycle cost and higher thermal efficiency would make the useful life of an MSBR considerably greatex than 30 years was considered. An increase in plant life to $\mathbf{4 5}$ years would produce a net rediutioun in the power

\footnotetext{
${ }^{44}$ PWR costs taken from J. A. Lane, M. L. Myers, and R. C. Otwon, Power Plant Copital Cost Normalization, ORNL-TM2385 (June 1969), phus 4\% excalation for the 1968 dollor. Since the couts in the Lase study were hased on the 1967 vilue of the collar, they were excaluted by $4 \%$ to more closely approximate 1968 conditions. The FWR indirect codts uned in the stody were not uned in the two-fluid MSBR extimate shown in Table 7.1 because they were not on the ame beda. For simplictity, the same value for indirect costs of 33.5\% was applied to the direct construntion cost of both the MSBR and FWR. A sales tax of 3\% was added to the construction cout of both types of plants.
}

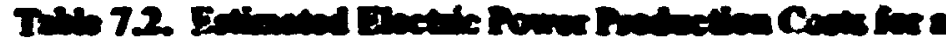

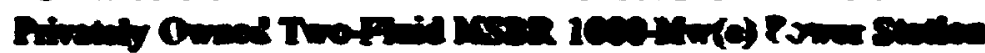
la enophose

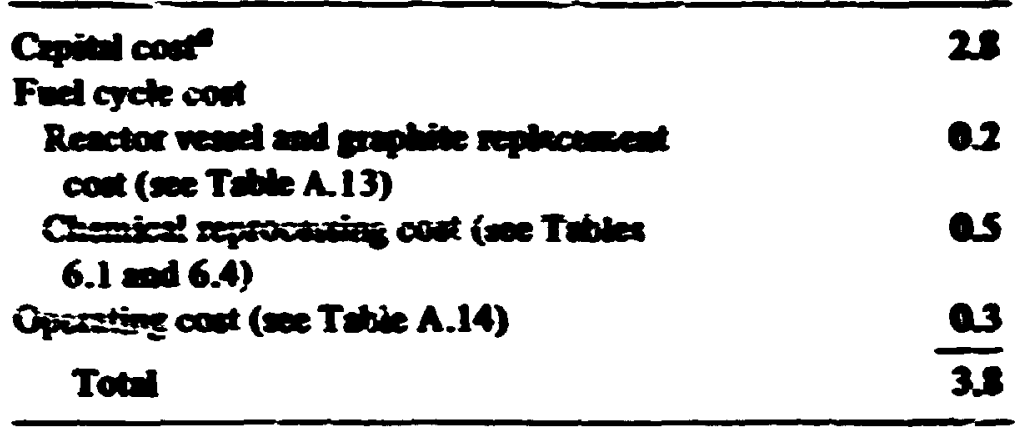

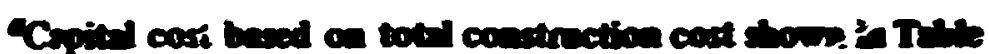

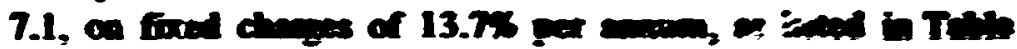
A.12, oul a phent factor of sech.

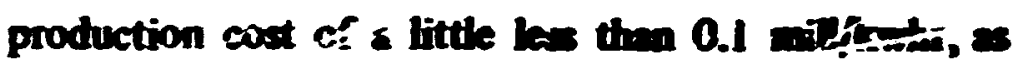
exphised in footnote $b$ of Teste fa. $i z$

Is "iptifing the fixed charge, no distinction mas inde vetween deprecintion and mosdeprecinting capiul in restment except for the irrentory composesess of the

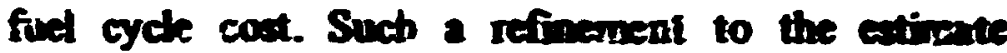
would be overshatewed by uscertinties in ofter conta The silrage selve of many of the itemes is not clear, the cocts of decontaminating and rechining such thins a hod, alt inventory, etc., mest be talanced anint the intrimic worth and the expense of dipoenl thet would othenvia be requirad.

The extisate of the cost of replacing the reactor vesels at the end of the useful life of the graphite cores is summarized in Table A.13. As explained in the footnotes to the table, an indirect cost of $10 \% \mathrm{wm}$ applied to the procurement of the replacement reactors. Many of the indirect costs of first construction would not be applicable to the replacement equipment. The lifetime of the core is such that the replacements can be made during periods of extensive generd mintenance of the plant and turbine generators, 80 no outage other than that included in the $80 \%$ phant fector was changed apinst the production coit. This seemed to be a reasonable approach since no downtime is required for refueling. If additional time were required for replacing the reactor vesceis, the cost of power would be increased by about $0.05 \mathrm{mill} / \mathrm{kwhr}$ for each two weeks of extra time. 4

Labor costs in addition to thowe for the repular phant maintenance crew were included ir. the resctor replece-

\footnotetext{
${ }^{45}$ Rry C. Robertion, Effere of Cone Griplite Lffe on Fown

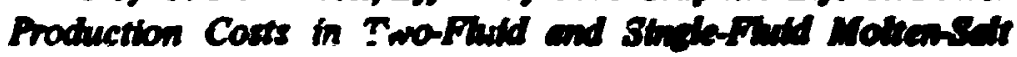
Breeder Reactors in 1000M(w/e) Pown Statione ONNL internal currespondence MSR-6846 Mar. 4, 1969).
} 


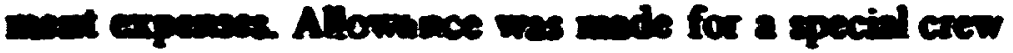

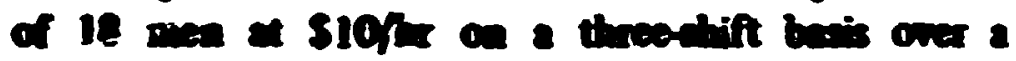
two-wouth pariod. This tine would include preparatory

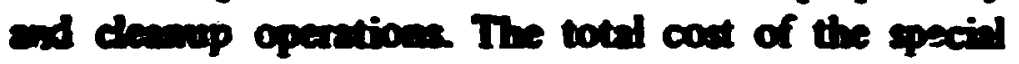
ithar actomats to $\$ 300,000$. Schedrling of the replace neat and other minterence operations bes not conshered in detal. The simplifying wemption was made thet the four modules would be repheced eresy cight yes.

A capitil cost anocinted with rephoement of reactor vench and cores was obthined by use of a rephecement coct factor. The cepital needed at the present time to consit to $\$ 1$ delf yours heace is $50.63,16$ years hence is $\$ 0.39$, and 24 years beace is $\$ 0.25$ if the interest nate is 6\%. The toted replacement cont factor is the sum of these, a 1.27. The ted repement sast of four Fenels and cores is $\$ 11$ million, so the capital that must be set aide at the tine of plant condruction for future renctor replesenenests is $\$ 14$ million. This copitel would not incur all the fired chros given in Trbie A.12 A we of $8 \%$ wo tiken as being more spproprinte in ariving at a total replacement cost of about 0.2 Thwhr.

The eximated fuel cycle cont for the two-finid MSBR is sumarized in Table 6.4. Amons the mojor constiments of the cont are itens anocinted with the lare capied inventent in inventories of farite and fertile materiols and carrier salt. The inventories were treated
25 a nondeprecinting invertment subject to fred cliages of 16x. The drity makeup and discard of salt in the procesing plent anount to complete replacement of the fud carier salt every five years.

The cod associated with the investment in proctsing equipment is aboit 0.1 mill/kwhr and is haeed on the equapmini susts reported in ORNL-3996.' This cost, cacalated to 1968 conditions, as explained in Table 6.4, is inctuded in the fuet cycle cont. The usual fixed charges of $13.7 \%$ and $80 \%$ phant factor were applied.

Operating costs soociated anly with the chemical proseaing were abo inchuded. A product eredit of cbout $0.1 \mathrm{mill} / \mathrm{kwhr}$ was catimated on the basis of a 4\% yield and ${ }^{23} \mathrm{UF}_{4}$ worth of about \$14/8. The total fuel cycle cost is about $0.5 \mathrm{mill} / \mathrm{kwhr}$, or about 0.7 mili/kwhr if the expence of replacing the reactor vesests and cores is inciuded.

The costs for operating the power station are sum manized in Table A.14. The total is about 0.3 mill/kwhr. It includes bobor and materinls for normal operation and mintenance, insurance, and miscellaneous services Abo inchuded is the expense of replacing coolant salt. This estimnte assumes $2 \%$ makeup per year and a cont of about 25//b for sodium flucroborate. Subrequent study and allowances for cactiation have resulted in more recent catimates of $50 \mathrm{H} / \mathrm{mb}$, although this would pousibly be reduced by quantity buying in a MSBR industry. 
ATrENDXX A: COST ESTMATES

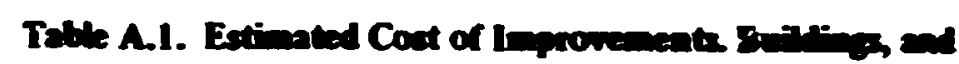
Structures for a 1000-1iv(e) power scition

\begin{tabular}{|c|c|}
\hline & $\begin{array}{l}\text { Cost } \\
\text { (thousonds } \\
\text { of dollers) }\end{array}$ \\
\hline Ground improvemeo's & 800 \\
\hline 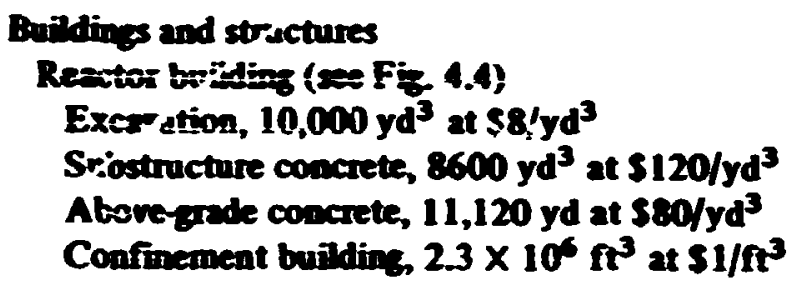 & $\begin{array}{r}80 \\
1,032 \\
850 \\
2,304\end{array}$ \\
\hline Turtine buiding, $290 \times 115 \times 125$ at $50.60 / \mathrm{ft}^{3}$ & 2,501 \\
\hline $\begin{array}{l}\text { Feedwater heater spece, } \\
50 \times 290 \times 80 \text { at } 50.60 / \mathrm{ft}^{3}\end{array}$ & 696 \\
\hline Ofinces, $50 \times 240 \times 20$ at $\$ 1.50 / \mathrm{ft}^{3}$ & 355 \\
\hline Control rooms, $50 \times 165 \times 20$ at $\$ 1.50 / \mathrm{ft}^{3}$ & 248 \\
\hline $\begin{array}{l}\text { Shop, } \\
50 \times 165 \times 80+50 \times 265 \times 20 \Omega 50.60 / \mathrm{ft}^{3}\end{array}$ & 555 \\
\hline Wate disposal buldisis & 150 \\
\hline Stant & 200 \\
\hline Warchorse & 40 \\
\hline Intake screen sinucture for cooling water & 700 \\
\hline Miscellaneoes & 30 \\
\hline Totai & $\overline{10,600}$ \\
\hline
\end{tabular}

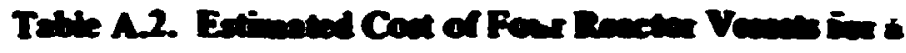

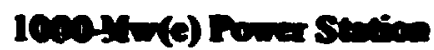

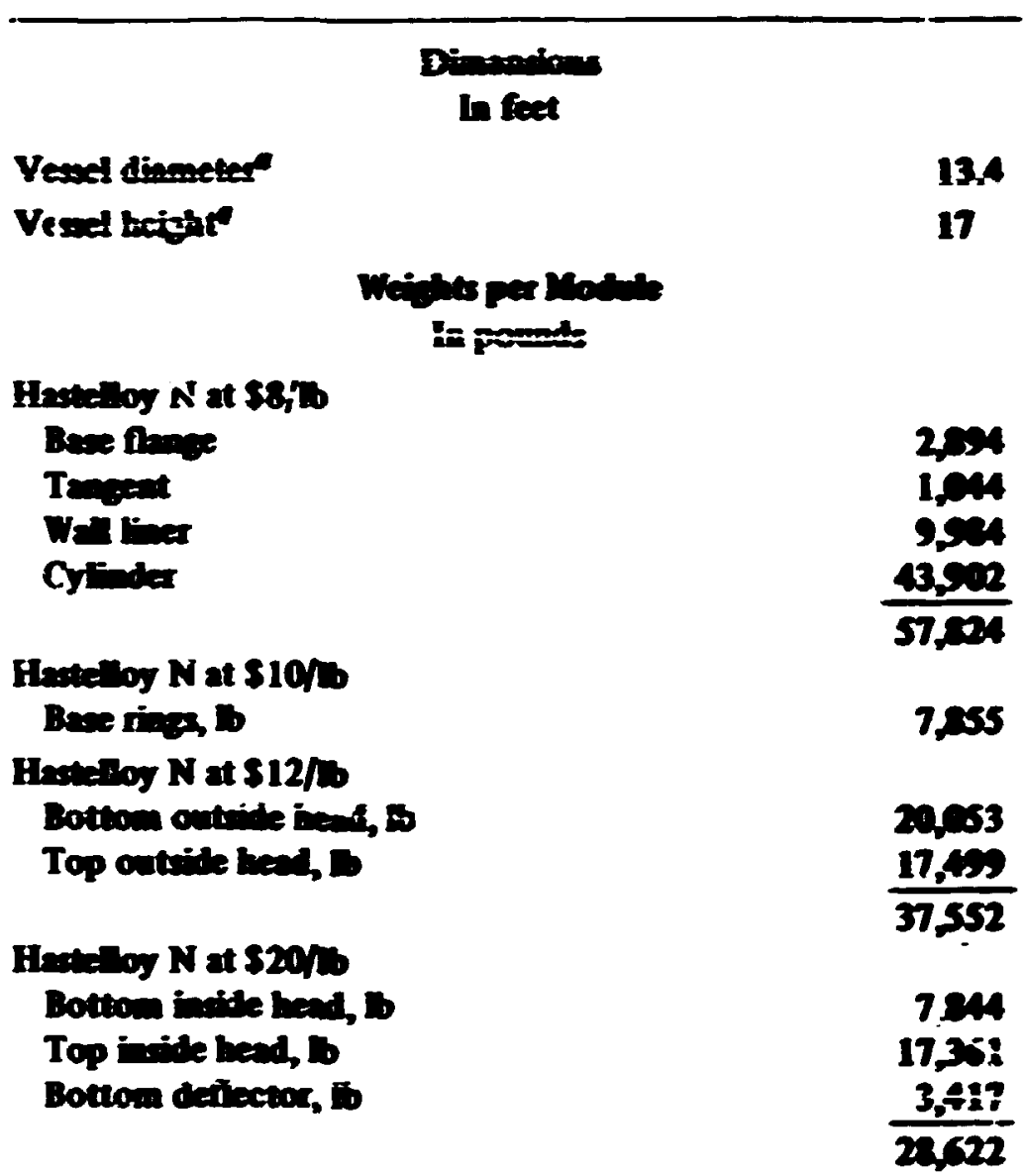

Conses

In mitions of dollas

\begin{tabular}{|c|c|}
\hline 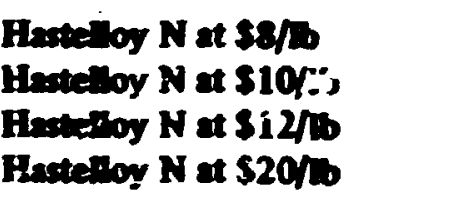 & $\begin{array}{l}0.53 \\
a \times 19 \\
0.451 \\
a, 572\end{array}$ \\
\hline Total for cane module & 1535 \\
\hline Totel + 10\% contingesy & 1.722 \\
\hline Total for four modales & $G$ \\
\hline
\end{tabular}

Timemaions of the core ured in the cont eximates ene shom in Table A.3. 


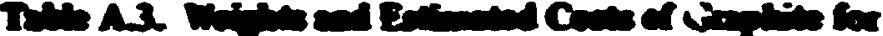

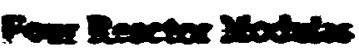

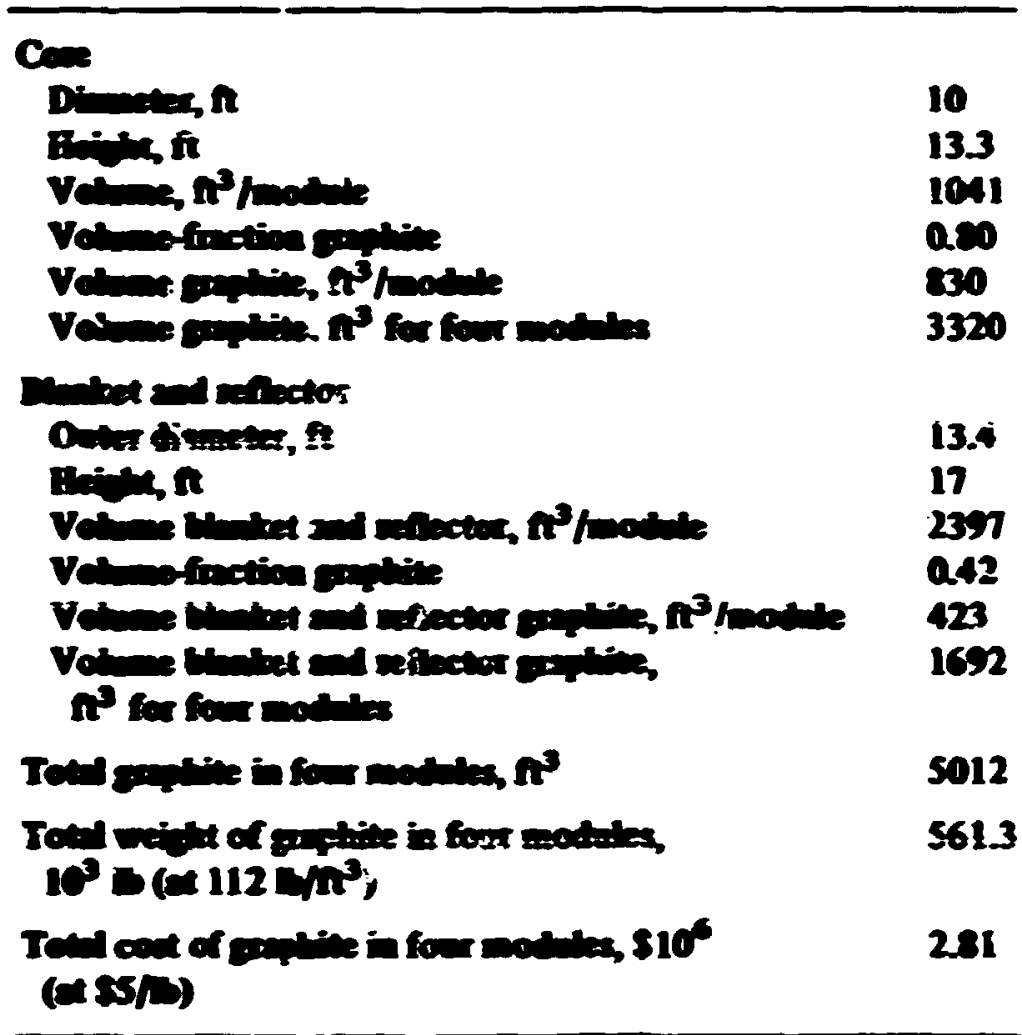

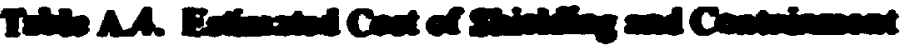

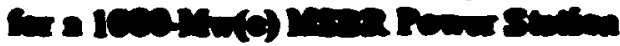

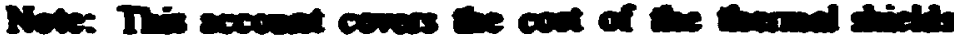

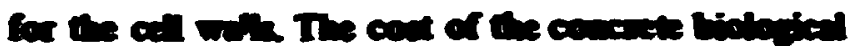

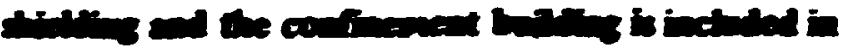
Trise 7.1.

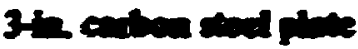

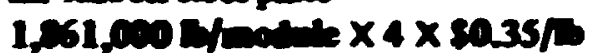

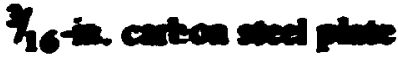

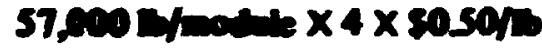

Y/2

137,200 rypole $\times 4 \times 50.35 / 10$

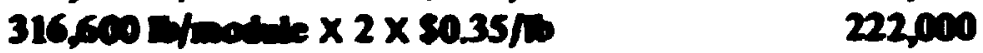

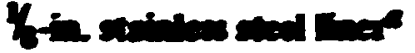

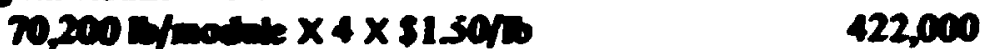

S6COOD $\times 2 \times 815010170,000$

indivions

127 sure $n^{2} /$ mone $\times 4 \times \$ 2 / \pi^{2} \quad 1,016,000$

$100000 n^{2} \times 2 \times 52 / \pi^{2}$

Tow

400,000

$\$ 5,142,000$

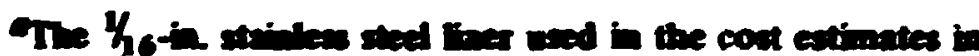

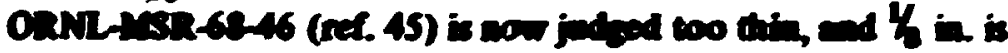
andrese

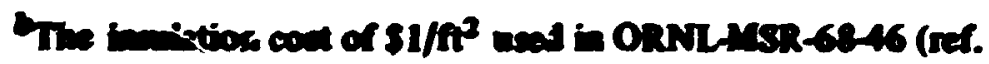
45) is betiened to be low. Altwong stil bot known with any

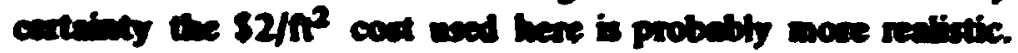

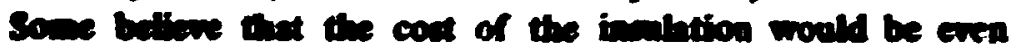
serist.

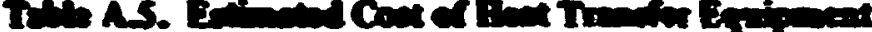

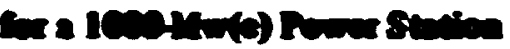

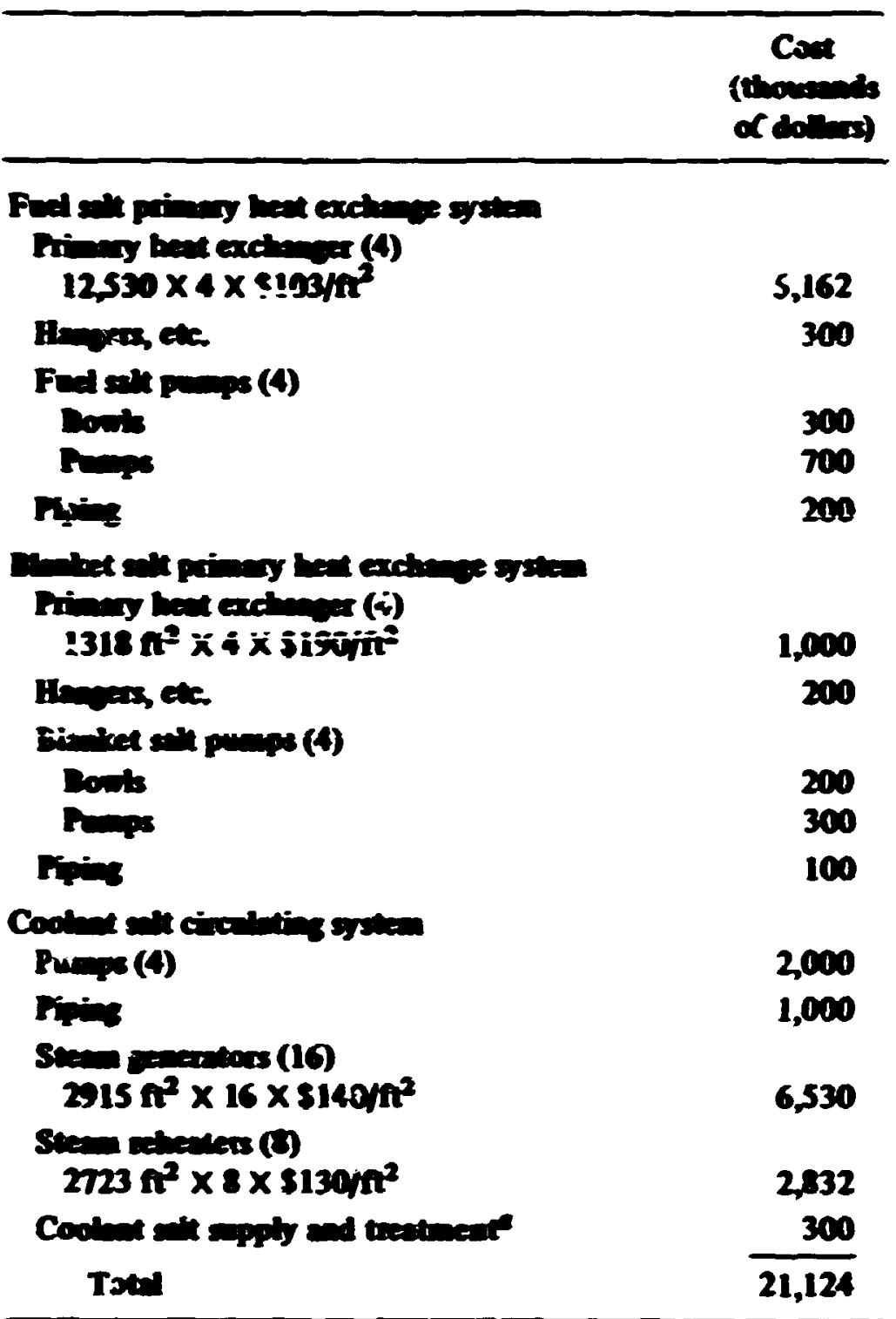

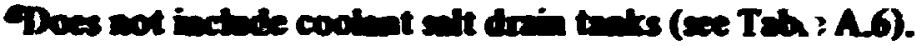




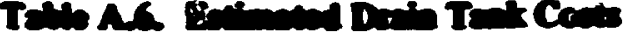

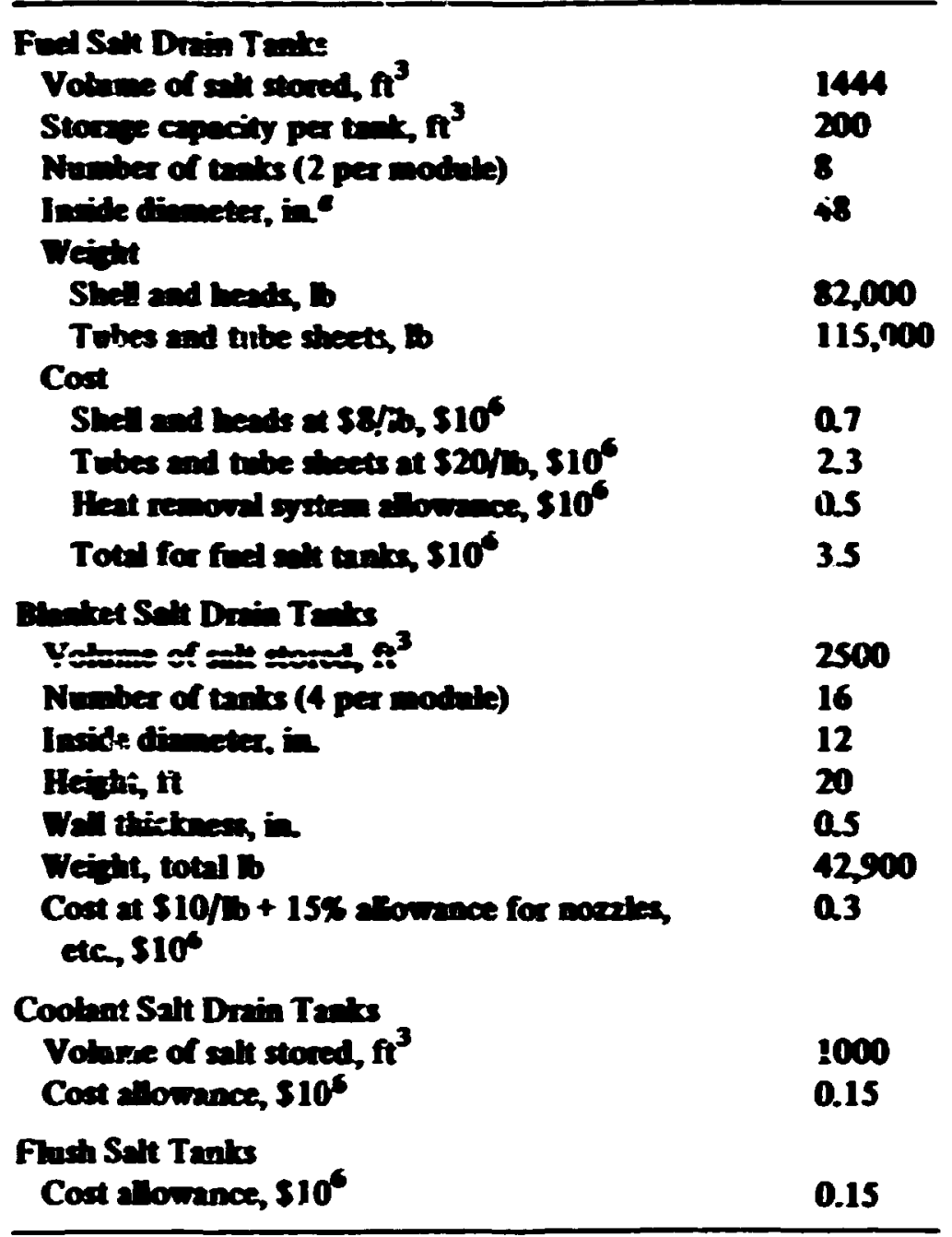

Subwequent studies indicated that a 60-in-ding tank way be required.

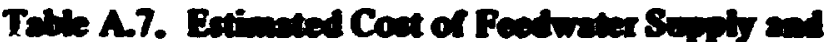
Treatineat Syiten for a 1000-yin(e) Station

\begin{tabular}{|c|c|}
\hline & $\begin{array}{l}\text { Coat } \\
\text { (thoumings } \\
\text { of dolians) }\end{array}$ \\
\hline $\begin{array}{l}\text { Makeup water suppily } \\
\text { Feedwater purification system } \\
\text { Feedwater heaters } \\
\text { Feedwater pumps and drives } \\
\text { Reheat steam preheaters (8) } \\
\text { Prescure-booster pumps (2) }\end{array}$ & $\begin{array}{r}4 \\
466 \\
1299 \\
1600 \\
275 \\
407\end{array}$ \\
\hline Total & 4050 \\
\hline Total, with $20 \%$ allownce for contingencies & 4800 \\
\hline
\end{tabular}

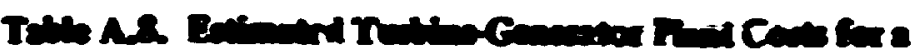

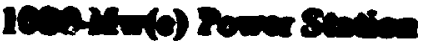

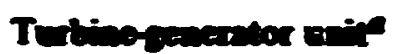

Cincolation weter gratemb

\$18,570000

1,40000

Condener and exilimies

1.rounes

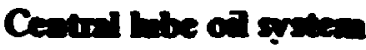

Twive phen inetruneatution

canes

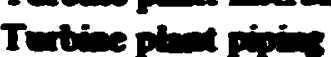

coneso

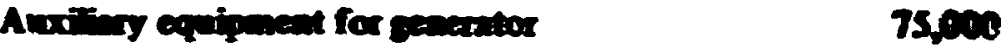

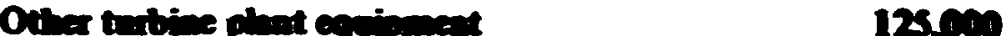

Tatine bypas (25x thotit Row)

300

Totel

523,2000010

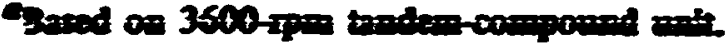

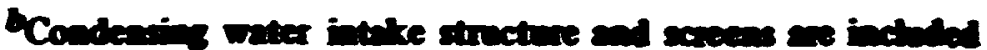
with structios and ingrovenceds (Table A.I).

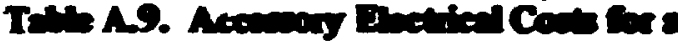

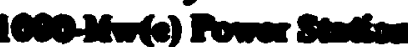

\begin{tabular}{|c|c|}
\hline 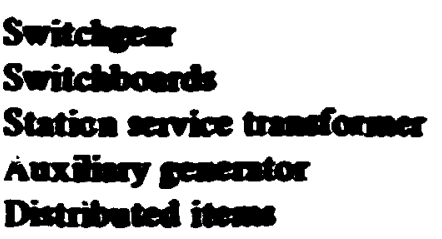 & $\begin{array}{r}775,000 \\
225,000 \\
252,000 \\
72,000 \\
3,100000 \\
\end{array}$ \\
\hline Total & sasap,ow \\
\hline
\end{tabular}

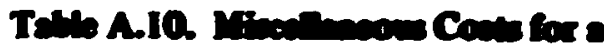

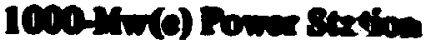

Turtine cratic and boints

$\$ 300,000$

Air and vacuum syatems

300,000

Communications systexas

50,000

Hechine took

300,030

Semice mater

300,000

Cootant ant inventory $(\$ 0.25 / 10)$

300,000

Total 


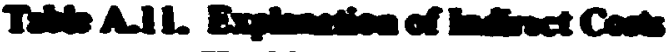
Und in Trens 7.1

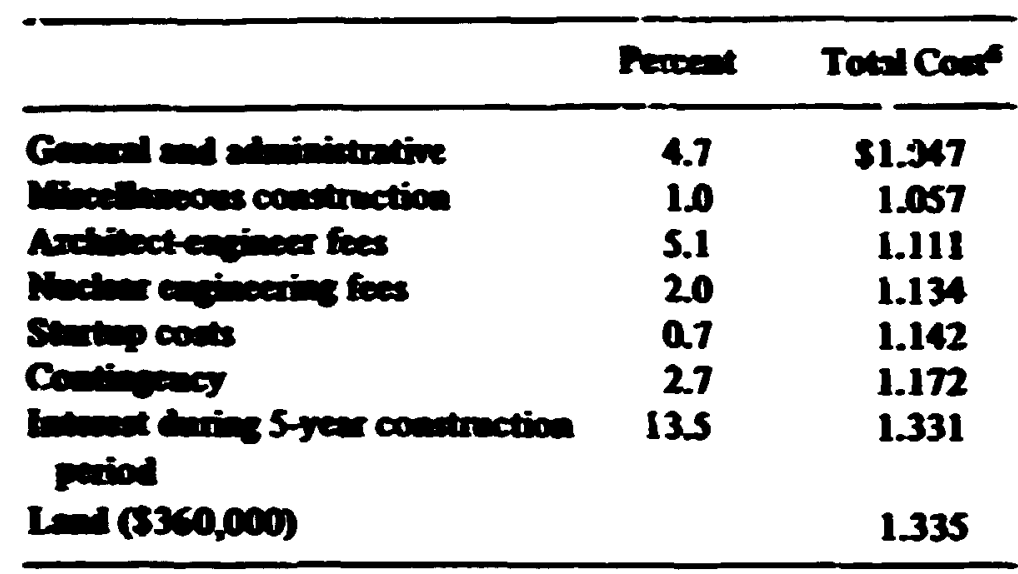

For disect cont of \$1.

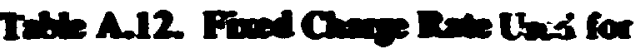
humboromed rower stuion

\begin{tabular}{|c|c|}
\hline & Rate (s/feri) \\
\hline 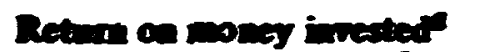 & 7.2 \\
\hline II & 1.02 \\
\hline & 0.35 \\
\hline 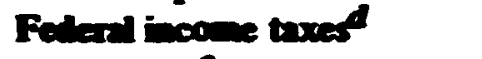 & 204 \\
\hline Other tures & 284 \\
\hline Inorace of $x$ the lingtiol & 0.25 \\
\hline Tow & 13.7 \\
\hline
\end{tabular}

Thetum based on $52 \%$ in bonds at $4.615 \%$ stume, $40 \%$ in equity copital at 10\%.

The sinkingfond method was uned in deter-

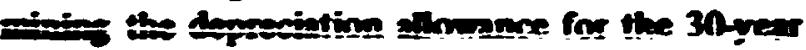
anded life of the plant. The deprecintion allow

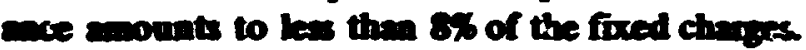
A 45-year life, say, world decrease this by abont two-thind and reduce the total fined chares to cbout 13.4\% per ammum

In accosilance with FTC practice, a $0.35 \%$ alowance was made for replecement of equipurent heving in anticipated life shorter than 30 years. (Reactor and anphite replecement is included in a speciel openting cont eccount)

Federal incosse taxes were based on "sum of the year digits" method of computing tax doferrak. The sinking-fund method was used to normalize this to a constant retum per year.

The recommended value of $2.84 \%$ was used for other taxes.

$f_{A}$ comentional allowance of $0.25 \%$ wes made for property damage insurance. Third-party ib biity insurance is listed as an operating cost.

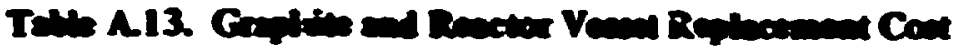

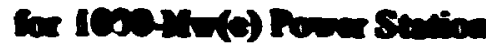

Reacior vand ow

Gropinice contb

Power rovene bos

$7.6 \times 10^{6}$

$.1 \times 10^{6}$

Nome

Lower cout

Total for four wodales per replecenent

$\frac{0.3 \times 10^{6}}{\$ 11.0 \times 10^{6}}$

Extimad Eis years

8

Rephosenesit cost factor (see text)

1.97

Tinty-yer replacs sent wod

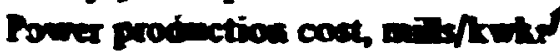

$\$ 14.0 \times 10^{6}$

a.16

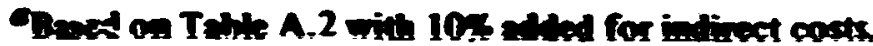

broved on Tais A.3 with $10 \%$ alled for indinect costs

CAvones the reactor in be rephoed within soind dow

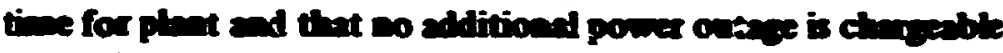
to expline aplocenent.

Lebor cout is in adition to that of cpention cres.

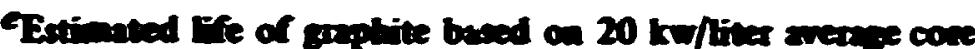

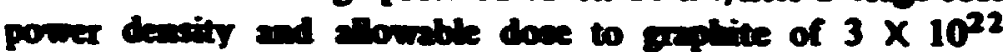
nentromedan ${ }^{2}$

Fower production cout for reactor repleceneat besed on $8 \%$ fred clunges for copitel and $80 \%$ phat factor.

Talle A.14. Opentiog Coats for 2 1000-1w(e) Ponve Station

\begin{tabular}{|c|c|}
\hline & Ammed \\
\hline $\begin{array}{l}\text { Touai payroll, } 70 \text { employees with } 20 \% \\
\text { finge bencitse }\end{array}$ & \& 554,000 \\
\hline Private ingumese & 260,000 \\
\hline Federal insurnece, at $\$ 30 / M-(t)$ & $\$ 6,800$ \\
\hline Repair and maintenance materiakb & $1,065,030 \mathrm{j}$ \\
\hline $\begin{array}{l}\text { Makeup arolant salt, at } 2 \% \text { of capital cost } \\
\text { Coatract services }\end{array}$ & $\begin{array}{r}7,000 \\
71,500\end{array}$ \\
\hline Total annual operating coste & $\$ 2,024,300$ \\
\hline
\end{tabular}

-Does not include special crew ured in replacing the reactor. This speciaf labor cost is included in the resctor replacement cost shown in Table A.13.

bDoes not inchude materials for repheing the reactor vescel and exphite (me Table A.13).

CTotal operating cost in milla/kwhr based on $80 \%$ plant factor is 0.29. This operating cost is esentially tive sume as that used in othex reactor evaluation studiex. 